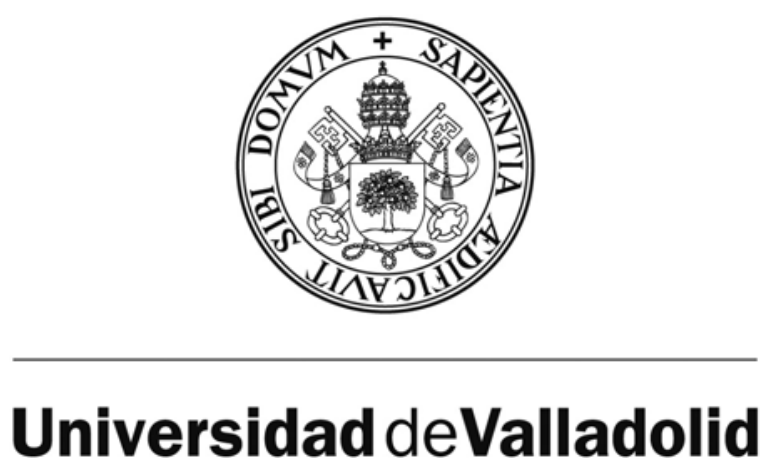

FACULTAD DE MEDICINA

DEPARTAMENTO DE BIOQUÍMICA Y BIOLOGÍA MOLECULAR Y FISIOLOGÍA

TESIS DOCTORAL:

Estudio de los mecanismos moleculares y celulares de la función protectora de la Apolipoproteína D

Presentada por Raquel Bajo Grañeras para optar al grado de doctora por la Universidad de Valladolid

Dirigida por:

María Dolores Ganfornina Álvarez

Diego Sánchez Romero 



\section{INDEX}

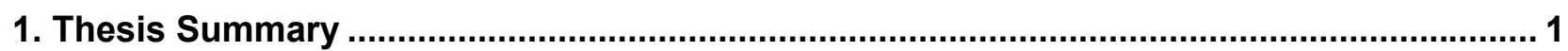

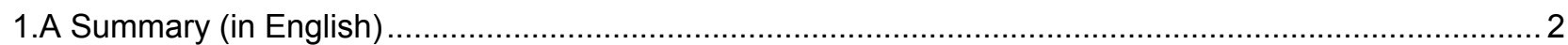

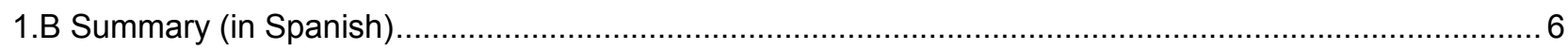

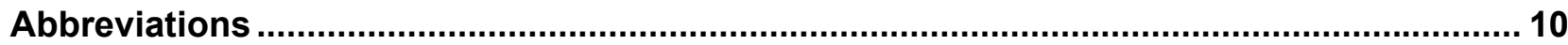

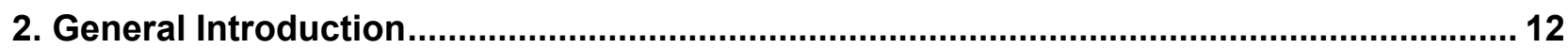

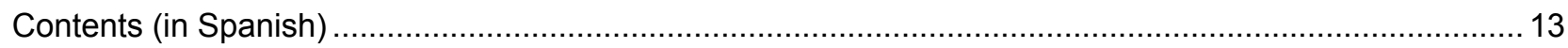

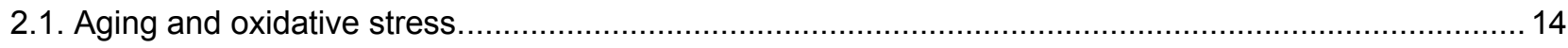

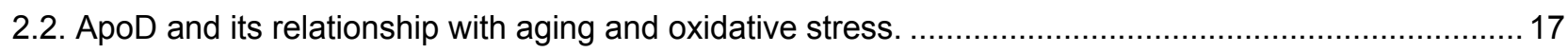

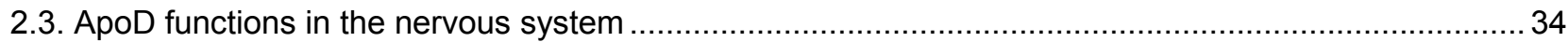

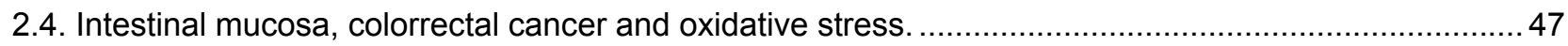

2.5. Signaling cascades related responding to oxidative stress: MAP kinases. .......................................... 54

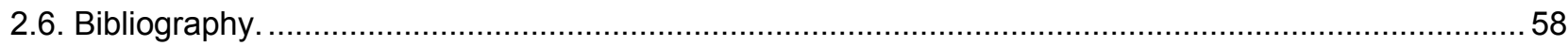

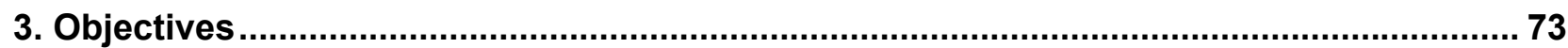

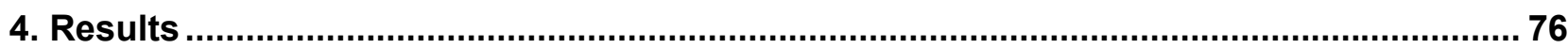

4.1.A ApoD function in the early transcriptional response to oxidative stress in the cerebellum

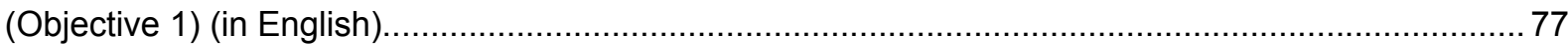

4.1.B Función de $A p o D$ en la respuesta transcripcional temprana al estrés oxidativo en el cerebelo (Objetivo 1) (in Spanish).

Paper (in English):

Bajo-Grañeras R, Sanchez D, Gutierrez G, González C, Do Carmo S, Rassart E, Ganfornina MD. "Apolipoprotein $D$ alters the early transcriptional response to oxidative stress in the adult cerebellum" Journal of Neurochemistry 2011 Jun;117(6):949-60.

4.2.A Apolipoprotein $D$ mediates autocrine protection of astrocytes and controls their reactivity level contributing to the functional maintenance of paraquat-challenged dopaminergic systems (Objective 2) (in English).

4.2.B Protección autocrina de ApoD sobre astrocitos, su nivel de reactividad y su contribución al mantenimiento de los sistemas dopaminérgicos al estrés oxidativo (Objetivo 2) (in Spanish). 109

Paper (in English):

Bajo-Grañeras R, Ganfornina MD, Martín-Tejedor E, Sanchez D. "Apolipoprotein D mediates autocrine protection of astrocytes and controls their reactivity level, contributing to the functional maintenance of paraquat-challenged dopaminergic systems" Glia2011 Oct;59(10):1551-66. 
4.3.A Protective effects of ApoD against oxidative stress on dopaminergic neurons modeling Parkinson's disease in vitro (Objective 3 ) (in English).

4.3.B Efectos protectores de ApoD frente al estrés oxidativo sobre neuronas dopaminérgicas que modelan in vitro la enfermedad de Parkinson (Objetivo 3) (in Spanish).

4.3.1. Exogenous addition of $A p o D$ improves viability of dopaminergic neurons exposed to $\mathrm{PQ}$.

4.3.2. Exogenous addition of $A p o D$ improves viability of differentiated dopaminergic neurons exposed to $P Q$.

4.3.3. Exogenous addition of $A p o D$ activates the ERK signaling cascade.

Bibliography

4.4.A Expression and possible role of $\mathrm{ApoD}$ in the survival / death balance in human colorectal cancer cells under oxidative stress conditions (Objective 4) (in English).

4.4.B Expresión y posible función de ApoD en el balance supervivencia/muerte en células de cáncer colorrectal humano sujetas a estrés oxidativo (Objetivo 4) (in Spanish)

Paper (in English):

Bajo-Grañeras R, Crespo-Sanjuan J, García-Centeno RM, Garrote-Adrados JA, Gutierrez G, GarcíaTejeiro M, Aguirre-Gervás B, Calvo-Nieves MD, Bustamante R, Ganfornina MD, Sanchez D. "Expression and potential role of Apolipoprotein $D$ on the death-survival balance of human colorectal cancer cells under oxidative stress conditions" Molecular Oncology, MS\#12-00171.

5. General Discussion 195

Bibliography

6. Conclusions

6.A Conclusions (in English). 203

6.B Conclusions (in Spanish). 204 


\section{INDICE}

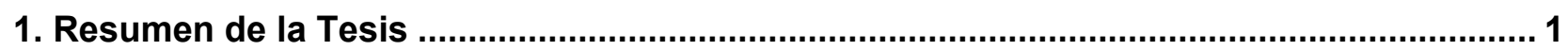

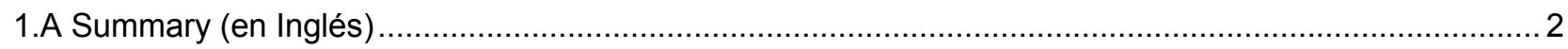

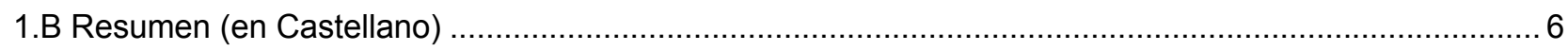

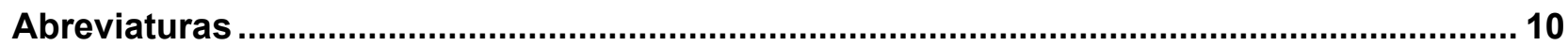

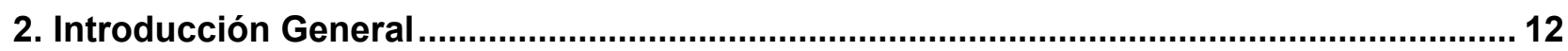

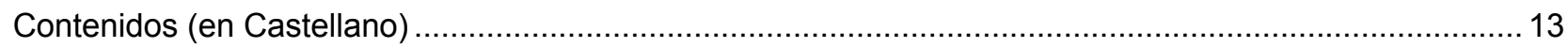

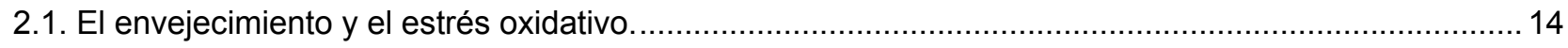

2.2. ApoD en el envejecimiento y su relación con el estrés oxidativo....................................................... 17

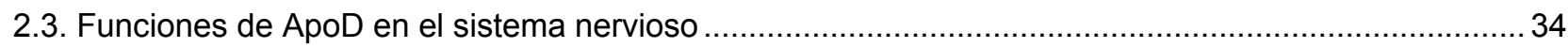

2.4. La mucosa intestinal, el cáncer colorrectal y el estrés oxidativo......................................................... 47

2.5. Cascadas de señalización relacionadas con las respuestas al estrés oxidativo: Las MAP

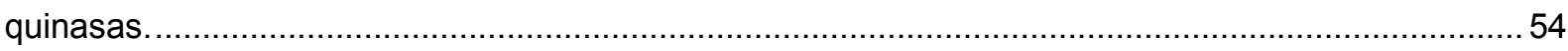

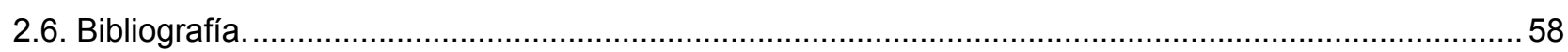

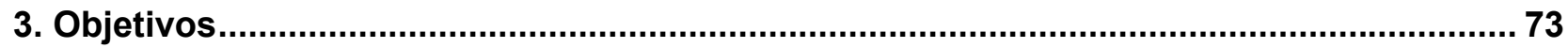

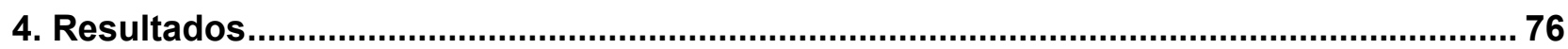

4.1.A ApoD function in the early transcriptional response to oxidative stress in the cerebellum (Objective 1) (en Inglés)...................................................................................................... 77

4.1.B Función de ApoD en la respuesta transcripcional temprana al estrés oxidativo en el cerebelo

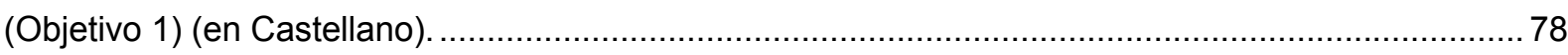

Trabajo (en Inglés):

Bajo-Grañeras R, Sanchez D, Gutierrez G, González C, Do Carmo S, Rassart E, Ganfornina MD. "Apolipoprotein $D$ alters the early transcriptional response to oxidative stress in the adult cerebellum" Journal of Neurochemistry 2011 Jun;117(6):949-60.

4.2.A Apolipoprotein $D$ mediates autocrine protection of astrocytes and controls their reactivity level contributing to the functional maintenance of paraquat-challenged dopaminergic systems (Objective 2) (en Inglés)...

4.2.B Protección autocrina de ApoD sobre astrocitos, su nivel de reactividad y su contribución al mantenimiento de los sistemas dopaminérgicos al estrés oxidativo (Objetivo 2) (en Castellano)...... 109

Trabajo (en Inglés):

Bajo-Grañeras R, Ganfornina MD, Martín-Tejedor E, Sanchez D. “Apolipoprotein D mediates autocrine protection of astrocytes and controls their reactivity level, contributing to the functional maintenance of paraquat-challenged dopaminergic systems" Glia2011 Oct;59(10):1551-66. 
4.3.A Protective effects of $A p o D$ against oxidative stress on dopaminergic neurons modeling Parkinson's disease in vitro (Objective 3) (en Inglés).

4.3.B Efectos protectores de ApoD frente al estrés oxidativo sobre neuronas dopaminérgicas que modelan in vitro la enfermedad de Parkinson (Objetivo 3) (en Castellano)

4.3.1. La adición exógena de ApoD mejora la viabilidad de neuronas dopaminérgicas ante la exposición a $\mathrm{PQ}$

4.3.2. La adición exógena de ApoD mejora la viabilidad de neuronas dopaminérgicas diferenciadas ante la exposición a $P Q$.

4.3.3. La adición exógena de ApoD activa la vía de señalización de ERK.

Bibliografía

4.4.A Expression and possible role of $A p o D$ in the survival / death balance in human colorectal cancer cells under oxidative stress conditions (Objective 4) (en Inglés).

4.4.B Expresión y posible función de ApoD en el balance supervivencia/muerte en células de cáncer colorrectal humano sujetas a estrés oxidativo (Objetivo 4) (en Castellano).

Trabajo (en Inglés):

Bajo-Grañeras R, Crespo-Sanjuan J, García-Centeno RM, Garrote-Adrados JA, Gutierrez G, GarcíaTejeiro M, Aguirre-Gervás B, Calvo-Nieves MD, Bustamante R, Ganfornina MD, Sanchez D. "Expression and potential role of Apolipoprotein $D$ on the death-survival balance of human colorectal cancer cells under oxidative stress conditions" Molecular Oncology, MS\#12-00171.

5. Discusión General 195

Bibliografía.

6. Conclusiones

6.A Conclusions (en Inglés).

6.B Conclusiones (en Castellano). 
1. Resumen 



\section{A. Summary}

ApoD is a secreted Lipocalin that has been functionally associated with aging, degeneration and nervous system damage, and with many cancer types as well. Recent work in model organisms like plants, flies and mice ${ }^{1-5}$ has shown that ApoD participates as a survival mechanism, conserved across species, against diverse oxidative stress situations.

In this thesis we propose four objectives aiming to understand the ApoD protective role in various physiological and pathological situations.

To carry out these objectives we have used biological models with high sensitivity to and/or high levels of oxidative stress. The experimental approach includes analyses at the following levels: 1) gene expression assays (microarrays or qPCR arrays), 2) biochemical assays (enzyme activity, lipid peroxidation, or dopamine levels), 3) cell cultures (cell lines or primary cultures), 4) tissue analyses (mouse nervous system tissue or human colorectal adenocarcinoma), and 5) locomotor behavior analyses in the whole organism (in the mouse experimental model).

We further ask whether ApoD function changes in different tissues or whether it works through a general mechanism of action everywhere it is expressed. The first three objectives of this work have been performed in the nervous system, an essentially post-mitotic tissue highly sensitive to stress. We have focused on glial cells (astrocytes), because this cell type predominantly responds against pro-oxidative situations; and on dopaminergic neurons because they are particularly sensitive to this type of stress. The last thesis objective aims at studying ApoD function in a proliferating tissue that is able to support high levels and tolerance to the oxidative stress caused by its high rate of ROS production (human colorectal cancer). Thus, we have been able to contrast the similarities and differences between both physiological situations to contextualize the relevance and impact of ApoD. 
In summary, the presence of $A p o D$ in the neuronal environment is necessary for an adequate protection against oxidative damage in the nervous system since it affects the transcriptional profile of the early response to this kind of stress. We have shown that ApoD preferentially alters the neuronal and oligodendroglial transcriptome with changes in expression of genes involved in neuronal excitability, synaptic transmission, management of myelin and the response to oxidative stress (Objective 1).

After demonstrating the influence of $A p o D$ in a proper glial response that could cushion the neurodegeneration associated with oxidative stress, we directed our study to the role of $A p o D$ in the important glia-glia and glia-neuron interactions within the nervous system. We show that ApoD is secreted by astrocytes in response to the ROS-generator paraquat, and that it has a beneficial effect on the functionality of the locomotor system in the mouse, particularly on the dopaminergic system. Our data demonstrate that ApoD expression is induced by the activation of the JNK signaling pathway and that it functions as an autocrine mechanism to protect astrocytes against oxidative stress. In addition, ApoD modulates astroglial reactivity and alters the astrocytes transcriptional response upon oxidative stress. The addition of human $A p o D$ to mouse astrocytes promotes their survival, further indicating the existence of mechanisms conserved across species. ApoD contributes to the endurance of astrocytes and reduces their reactivity both in vitro and in vivo. These two effects are sufficient to improve the functionality of the nigrostriatal dopaminergic system (Objective 2).

The observed decrease in the impact of damage in neurons of the substantia nigra could be due to a combination of the benefits of a healthy surrounding glia and the direct effects of ApoD on neurons. Among other glial factors released to extracellular medium, ApoD could perform direct effects on the viability of neurons. We tested this hypothesis and found that ApoD is effective even in PINK1 deficient dopaminergic neurons (a Parkinson's disease model) and that these beneficial effects are mediated by ERK signaling pathway activation which promotes cell survival (Objective 3). 
After observing what happens in the nervous system, where ApoD plays a protective role both for glia and for damaged neurons, we wanted to study a very different model to confirm if ApoD protective effects are applicable.

For this purpose we have used human colorectal cancer tissues and a cell line of colon cancer. Both strategies have allowed us to observe a negative correlation between the ApoD expression and cancer progression. This represents a paradox because oxidative stress increases along cancer progression. Our study shows that cancer cells are able to respond to prooxidant stimuli. Even though ApoD expression is low in the stromal cells, it increases in the dysplastic epithelium. Finally, ApoD modifies neither the proliferation rate nor apoptosis levels in control conditions, but it promotes apoptosis under oxidative stress conditions. Therefore ApoD might become a therapeutic resource to promote cancer cell death when they are under stress (Objective 4).

The general conclusion extracted from these results is that ApoD is a protein able to perform protective effects in different systems upon oxidative stress, promoting cell survival in glial and neurons (essentially post-mitotic cells), but promoting cell death in neoplastic cells under oxidative stress. Our work also uncovers some of the mechanisms by which this apparently pleiotropic protein is able to control the survival/death balance in both physiological and pathological conditions of diverse etiology.

\section{Bibliography}

1. Charron JB, Ouellet F, Houde M, Sarhan F. The plant Apolipoprotein D ortholog protects Arabidopsis against oxidative stress. BMC Plant Biol. 2008;8:86.

2. Ganfornina MD, Do Carmo S, Lora JM, Torres-Schumann S, Vogel M, Allhorn M, González C, Bastiani MJ, Rassart E, Sanchez D. Apolipoprotein $D$ is involved in the mechanisms regulating protection from oxidative stress. Aging Cell. 2008;7(4):506-515.

3. Hull-Thompson J, Muffat J, Sanchez D, Walker DW, Benzer S, Ganfornina MD, Jasper H. Control of metabolic homeostasis by stress signaling is mediated by the lipocalin NLaz. PLoS Genet. 2009;5(4):e1000460. 
4. Ruiz M, Sanchez D, Canal I, Acebes A, Ganfornina MD. Sex-dependent modulation of longevity by two Drosophila homologues of human Apolipoprotein D, GLaz and NLaz. Experimental Gerontology. 2011;doi: DOI: 10.1016/j.exger.2011.02.014.

5. Sanchez D, Lopez-Arias B, Torroja L, Canal I, Wang X, Bastiani MJ, Ganfornina MD. Loss of glial lazarillo, a homolog of apolipoprotein D, reduces lifespan and stress resistance in Drosophila. Curr Biol. 2006;16(7):680-686. 


\section{B. Resumen}

ApoD es una lipocalina secretada que se ha vinculado con el envejecimiento, la degeneración y la lesión del sistema nervioso, al igual que con muchas formas de cáncer. Trabajos recientes realizados en organismos modelo tan diferentes como plantas, moscas o ratones ${ }^{1-5}$ han demostrado que ApoD participa como mecanismo de supervivencia, conservado en muchas especies, en la lucha contra el estrés oxidativo en diversas situaciones.

En esta tesis nos proponemos cuatro objetivos encaminados a conocer el papel protector que desempeña ApoD en varias situaciones fisiológicas y patológicas.

Para llevarlos a cabo hemos usado modelos biológicos con altos niveles de estrés oxidativo y/o con gran sensibilidad al estrés. La aproximación experimental abarca los siguientes niveles de análisis: 1) ensayos de expresión génica (microarrays o qPCR arrays), 2) ensayos bioquímicos (actividad enzimática, lípidos peroxidados o niveles de dopamina), 3) cultivos celulares (líneas celulares o cultivos primarios), 4) análisis de tejido (sistema nervioso de ratón o tejido de adenocarcinoma colorrectal humano), y 5) análisis de comportamiento locomotor en el organismo completo (en el modelo experimental del ratón).

Nos preguntamos además si el papel de ApoD es muy diferente en distintos tejidos o si mantiene un mecanismo de acción generalizable. Los tres primeros objetivos de este trabajo se han llevado a cabo en el sistema nervioso, un tejido esencialmente post-mitótico altamente sensible al estrés. Hemos centrado nuestro punto de mira en las células gliales que responden predominantemente a situaciones pro-oxidantes, los astrocitos, y en las neuronas especialmente sensibles a este tipo de estrés, las dopaminérgicas. El último objetivo está dedicado al estudio de ApoD en un tejido en proliferación constante y con gran tolerancia al estrés oxidativo originado por su alta tasa de producción de ROS (el cáncer colorrectal humano). De este modo hemos podido contrastar las 
semejanzas y diferencias que existen entre estas dos situaciones fisiológicas para contextualizar la relevancia y la repercusión de ApoD.

En resumen, la presencia de $A p o D$ en el entorno neuronal es necesaria para una adecuada protección contra el daño oxidativo dentro del sistema nervioso ya que influye en el perfil transcripcional de la respuesta temprana contra ese estrés. Hemos demostrado que ApoD altera de forma preferente el transcriptoma neuronal y oligodendroglial alterando la expresión de genes involucrados en la excitabilidad neuronal, la transmisión sináptica, la gestión de la mielina y la respuesta al estrés oxidativo (Objetivo 1).

Tras observar la influencia de ApoD en una correcta respuesta glial que pudiera amortiguar la neurodegeneración relacionada con el estrés oxidativo, nos propusimos estudiar el papel de ApoD en las importantes interacciones glía-glía y glía-neurona dentro del sistema nervioso. Hemos demostrado que ApoD es secretada por los astrocitos en respuesta a un generador de ROS (el paraquat) y que desempeña un efecto beneficioso sobre la funcionalidad del sistema locomotor y, en concreto, del sistema dopaminérgico. Nuestros datos demuestran que la expresión de $A p o D$ es inducida por la vía de señalización de JNK y funciona como un mecanismo autocrino en la protección de los astrocitos contra el estrés oxidativo. Además ApoD modula la reactividad glial, y altera la respuesta transcripcional de los astrocitos al estrés oxidativo. La adición de ApoD humana a los astrocitos de ratón promueve su supervivencia indicando la existencia de mecanismos conservados. ApoD contribuye a la estabilidad de los astrocitos y reduce su reactividad tanto in vitro como in vivo, siendo estos efectos suficientes para mejorar la funcionalidad del sistema dopaminérgico nigroestriatal (Objetivo 2).

La reducción del impacto dañino observado en las neuronas de la sustancia negra, parece deberse a una combinación entre los efectos beneficiosos que aporta gozar de una glía circundante saludable y efectos directos de ApoD sobre las neuronas. Entre otros factores la glía libera ApoD al medio extracelular y ésta podría ejercer efectos directos sobre la viabilidad de las neuronas. Hemos contratado esta hipótesis y hemos comprobado que ApoD es 
efectiva incluso para neuronas dopaminérgicas deficientes en PINK1, que modelan la enfermedad de Parkinson y que los efectos beneficiosos de ApoD están mediados por la activación de la vía de señalización de ERK que promueve la supervivencia (Objetivo 3).

Después de observar lo que sucede en el sistema nervioso, donde ApoD desempeña un papel de protección tanto sobre la glía que la produce como sobre las neuronas dañadas, pasamos a estudiar un modelo muy diferente para ver si se corroboran los efectos protectores de ApoD.

Para este objetivo hemos usado tejidos de cáncer colorrectal humano y una línea celular de cáncer de colon. Ambas estrategias nos han permitido observar una correlación negativa entre la expresión de $A p o D$ y la progresión del cáncer. Esto representa una paradoja dado que el estrés oxidativo aumenta con la progresión del cáncer. Nuestro estudio demuestra que las células cancerosas son capaces de responder a estímulos pro-oxidantes de forma que la expresión de $A p o D$ en el tumor es baja en el estroma pero alta en el epitelio displásico. Por último, ApoD no modifica ni la tasa de proliferación ni la muerte por apoptosis en situación control, pero promueve la apoptosis en condiciones de estrés oxidativo. ApoD por tanto puede convertirse en un recurso terapéutico para promover la muerte de células cancerosas en situaciones de estrés (Objetivo 4).

De todos estos resultados podemos extraer la conclusión general de que ApoD es una proteína que desempeña efectos de protección en diferentes sistemas ante el estrés oxidativo, promoviendo supervivencia en células gliales y neuronales (esencialmente post-mitóticas) pero promoviendo muerte celular en células neoplásicas sujetas a estrés oxidativo. Nuestro trabajo descubre además algunos de los mecanismos por los que esta proteína, aparentemente pleiotrópica, es capaz de controlar el balance supervivencia/muerte celular tanto en condiciones fisiológicas como patológicas de diversa índole. 


\section{Bibliografía}

1. Charron JB, Ouellet F, Houde M, Sarhan F. The plant Apolipoprotein D ortholog protects Arabidopsis against oxidative stress. BMC Plant Biol. 2008;8:86.

2. Ganfornina MD, Do Carmo S, Lora JM, Torres-Schumann S, Vogel M, Allhorn M, González C, Bastiani MJ, Rassart E, Sanchez D.

Apolipoprotein $\mathrm{D}$ is involved in the mechanisms regulating protection from oxidative stress. Aging Cell. 2008;7(4):506-515.

3. Hull-Thompson J, Muffat J, Sanchez D, Walker DW, Benzer S, Ganfornina MD, Jasper $\mathrm{H}$. Control of metabolic homeostasis by stress signaling is mediated by the lipocalin NLaz. PLoS Genet. 2009;5(4):e1000460.

4. Ruiz M, Sanchez D, Canal I, Acebes A, Ganfornina MD. Sex-dependent modulation of longevity by two Drosophila homologues of human Apolipoprotein D, GLaz and NLaz. Experimental Gerontology. 2011;doi: DOI: 10.1016/j.exger.2011.02.014.

5. Sanchez D, Lopez-Arias B, Torroja L, Canal I, Wang X, Bastiani MJ, Ganfornina MD. Loss of glial lazarillo, a homolog of apolipoprotein D, reduces lifespan and stress resistance in Drosophila. Curr Biol. 2006;16(7):680-686. 


\section{Abreviaturas}

- ApoD: Apolipoproteína D

- PQ: Paraquat (metil-viologen) (1,1-dimetil-4,4-bipiridinio)

- ROS: (Reactive Oxigen Species) Especies reactivas de oxígeno

- RNS: (Reactive Nitrogen Species) Especies reactivas de nitrógeno

- ADN: Ácido Desoxi-Ribo-Nucleico

- ADNc: ADN codificante

- HDL: (High Density Lipoproteins)Lipoproteínas de alta densidad

- VLDL: (Very Low Density Lipoproteins) Lipoproteínas de muy baja densidad

- AA: (Araquidonic acid) Ácido araquidónico

- hApoD: (human ApoD) ApoD humana

- SDS-PAGE: (SDS-Poly-Acrylamide Gel Electrophoresis) Electroforesis en gel de poliacrilamida con SDS

- LCAT:

- GLaz: (Glial Lazarillo) Lazarillo Glial

- NLaz: (Neural Lazarillo) Lazarillo Neural

- WT: (Wild type) individuo silvestre

- KO: (Knock-out) individuo con mutación de pérdida de función en un determinado gen

- Tg: (Transgenic) individuo transgénico con ganancia de función en un determinado gen

- APP: (Amiloid Protein Precursor) Proteína precursora del amiloide

- ARN: Ácido Ribo-Nucleico

- ARNm: Ácido Ribo-Nucleico mensajero

- LPL: Lipoprotein Lipasa

- MAPK: (Mitogen Activated Protein Kinases) Proteínas quinasas activadas por mitógenos

- ERK: (Extracellular signal-regulated kinases) Proteínas quinasas activadas por señales extracelulares

- JNK: (c-jun N-terminal Kinase) Quinasa N-terminal de c-jun 
- Akt: (Protein kinase B) Ser/Thr quinasa

- SN: Sistema nervioso

- SNC: Sistema nervioso central

- SNP: Sistema nervioso periférico

- MPTP: Neurotoxina 1-metil-4 fenil-1,2,3,6-tetrahidropiridina

- $\mathrm{MPP}^{+}$: Metabolito activo de la MPTP (1-metil-4 fenilpiridinio)

- ATP: (Adenosine Tri-Phosphate) Adenosina tri-fosfato

- GABA: (Gamma-aminobutyric acid) Neurotransmisor GABA

- GFAP: (Glial Fibrilar Acidic Protein) Proteína acídica fibrilar glial

- SNpc: Sustancia Negra pars compacta

- DOPA: Dihidrofenilalanina

- MAO: Monoaminooxidasa

- COMT: Catecol-O-metil-transferasa

- PINK1: (PTEN-induced novel kinase 1) Nueva proteína quinasa 1 inducida por PTEN

- DJ1: Parkina 7

- TNM: (Tumor-Nodes-Metastasis) Tumor-Ganglios-Metástasis

- LPS: (Lipopolysacharide) Lipopolisacárido

- BDNF: (Brain-Derived Neurotrophic Factor) Factor neurotrópico derivado del cerebro 
2. Introducción General 



\section{Introducción General}

2.1. El envejecimiento y el estrés oxidativo.

2.2. ApoD en el envejecimiento y su relación con el estrés oxidativo.

2.2.1. Biología molecular de ApoD

2.2.2. Papel de ApoD y sus genes homólogos en el envejecimiento

2.2.3. ApoD y las patologías asociadas al envejecimiento

2.2.3a. Las enfermedades del sistema nervioso

2.2.3b. Las enfermedades cardiovasculares y metabólicas

2.2.3c. El Cáncer

2.2.4. ApoD y la proliferación celular

2.2.5. ApoD y el estrés oxidativo

\subsection{Funciones de ApoD en el sistema nervioso}

2.3.1. El sistema nervioso y su vulnerabilidad al estrés oxidativo.

2.3.2. ApoD y el cerebelo

2.3.3. ApoD y los astrocitos

2.3.4. ApoD y el sistema dopaminérgico

2.4. La mucosa intestinal, el cáncer colorrectal y el estrés oxidativo.

2.4.1. Curso temporal y características del adenocarcinoma colorrectal

2.4.2. ApoD y el adenocarcinoma colorrectal

2.5. Cascadas de señalización relacionadas con las respuestas al estrés oxidativo: Las MAP quinasas.

1.5.1. Vías de señalización que controlan o son controladas por ApoD

\subsection{Bibliografía.}





\subsection{El envejecimiento y el estrés oxidativo.}

El envejecimiento es un intrincado fenómeno caracterizado por el declive progresivo de las funciones biológicas y un incremento en la mortalidad que a menudo viene acompañada de enfermedades dependientes de la edad. Es un proceso universal. Está conservado en todos los organismos, es deletéreo, progresivo, endógeno e irreversible. El envejecimiento se asocia con un aumento de las especies reactivas del oxígeno (ROS) y del nitrógeno (RNS). Estas moléculas son capaces de reaccionar con proteínas, lípidos y ácidos nucleicos provocando la perdida de sus funciones biológicas ${ }^{1}$.

Desde hace años hay evidencias muy sólidas de que las especies reactivas de oxígeno (ROS) están estrechamente asociadas con muchas condiciones y procesos patológicos, especialmente con aquellas enfermedades relacionadas con el envejecimiento. Las primeras pruebas claras de esta asociación se obtuvieron al reconocer que la radiación ionizante provocaba la formación de ROS y también daño en los tejidos que posteriormente desarrollaban cáncer. La asociación de los radicales libres con las radiaciones ionizantes permitió establecer un fuerte paralelismo entre la toxicidad que produce el oxígeno y el daño por radiación ionizante ${ }^{2}$. Así comenzaron las investigaciones, al principio lentamente, hasta llegar a postular una teoría que da una importancia especial al papel que juegan los radicales libres en el envejecimiento ${ }^{3}$ y en el desarrollo del cáncer ${ }^{4}$. Estos avances se siguieron de una corriente de investigación que sigue creciendo y que se mantiene en la actualidad estudiando el papel de los ROS en múltiples sistemas biológicos.

La comprensión de que el estrés oxidativo es una consecuencia natural en todos los sistemas biológicos que dependen del oxígeno para la vida ${ }^{5}$ y de que los ROS son utilizados como agentes de señalización en condiciones normales (y no sólo cómo agentes causantes de daños), ha conducido a un aumento de publicaciones científicas que enriquece el conocimiento que se tiene actualmente de la acción multifacética de los ROS tanto en los procesos biológicos normales como en muchos procesos patológicos. 
Cada vez es mayor el número de grupos de investigación que analizan las implicaciones de los ROS en los mecanismos fundamentales que ocasionan el desarrollo del cáncer, el ictus, la enfermedad de Alzheimer, la enfermedad de Parkinson, las enfermedades cardiovasculares, la artritis, la diabetes, y muchas otras enfermedades relacionadas con el envejecimiento, así como en muchas otras condiciones patológicas. Todo ello contribuyó a un optimismo creciente respecto a posibles nuevas terapias basadas en mitigar la acción de los ROS en el desarrollo de estas enfermedades. Sin embargo se ha observado que no es tan sencillo.

Es ampliamente reconocido que los sistemas biológicos que requieren oxígeno para la vida están sometidos a distintos niveles de estrés oxidativo en todo momento. Los sistemas biológicos producen diversas especies reactivas oxidantes, en condiciones normales y cuando se encuentran bajo diversas condiciones patológicas. Los ROS producidos incluyen el anión superóxido $\left({ }^{\circ} \mathrm{O}_{2}{ }^{-}\right)$, el peróxido de hidrógeno $\left(\mathrm{H}_{2} \mathrm{O}_{2}\right)$, el radical hidroxilo $\left({ }^{\circ} \mathrm{OH}\right)$, así como el oxígeno singlete $\left({ }^{1} \mathrm{O}_{2}\right)$ que se genera en ciertas condiciones, y el óxido nítrico (NO). El óxido nítrico puede sufrir numerosas reacciones con diferentes moléculas biológicas para producir diversos productos de reacción que tienen consecuencias importantes en los procesos biológicos. Además actúa por sí mismo como señalizador, difundiendo a través de la célula que lo ha producido.

Los radicales libres tienen un gran poder oxidante que puede llegar a alterar, con un efecto dominó, tanto proteínas, como ácidos nucleicos y lípidos. La oxidación de las proteínas ocurre preferentemente en determinados residuos (como las cisteínas) que son más reactivos. Incluso pueden llegar a romperse, perdiendo actividad. Los ácidos nucleicos sufren hidroxilaciones en las bases nitrogenadas, provocando la escisión de las hebras de ADN. Esto explica su relación con la carcinogénesis. Los lípidos por su parte se peroxidan, especialmente los ácidos grasos poli-insaturados que son abundantes en las membranas celulares. Estas peroxidaciones se propagan, afectando a otros ácidos grasos adyacentes y produciendo roturas en las membranas que dejan de ser funcionales. Como productos de dicha peroxidación lipídica se producen 
principalmente el malondialdehído y el 4-hidroxi-2-nonenal, que pueden usarse como marcadores ${ }^{7}$.

A pesar de conocer que el envejecimiento es un proceso de carácter irreversible, como he comentado al principio, el hombre ha intentado siempre evitarlo y los científicos llevan décadas intentando al menos retrasarlo. Esto convierte al envejecimiento en el tema central de trabajo en muchos laboratorios.

Posiblemente uno de los primeros intentos para tratar de modificar el ritmo del envejecimiento fue la serie de experimentos con antioxidantes llevados a cabo por Denham Harman, el científico pionero que expuso la "teoría de los radicales libres en el envejecimiento". Estos experimentos, realizados en ratones entre los años 70 y los 80 , se basaron en la premisa de que las reacciones de los radicales libres contribuyen significativamente a la degradación de los sistemas biológicos y que esto sucedía de manera importante en el envejecimiento, por tanto, que la administración de antioxidantes en la dieta podría aumentar la vida media ${ }^{8}$. Esto hizo que los radicales libres biológicos se consideraran el objetivo terapéutico. Se probaron antioxidantes químicos bien conocidos como la vitamina $E$, entre otros. Sin embargo, los experimentos, en general, no mostraron los resultados esperados. Fueron mejoras de la vida media con modesta reproducibilidad, mostrando que el proceso no es tan sencillo como se planteaba $^{9}$. Probablemente el que se hicieran tantos intentos infructuosos, se debió en su mayoría a intentar extrapolar directamente a un organismo completo las reacciones químicas que se producen entre los antioxidantes y los radicales libres en un tubo de ensayo. Además, parte de los prometedores inicios pudieron deberse a que el tratamiento con antioxidantes constituía un suplemento en la dieta que compensaba las carencias que entonces tenían los animales. Con las prácticas de cría de animales actuales, que son mucho más rigurosas, y el estudio de la biodisponibilidad de los antioxidantes se ha aumentado la cautela ante el uso indiscriminado de estas sustancias antioxidantes. Una revisión publicada recientemente acerca del tema señala los problemas asociados a la sobre-explotación de los antioxidantes como "elixir de la juventud"10. 
Recientemente se han identificado otras maneras de incrementar la longevidad, algunas de ellas gracias al desarrollo de nuevas herramientas genéticas que están actualmente disponibles en organismos modelo como son: 1) Ingesta restringida de alimentos ('Dietary restriction' DR), sin que lleve a la malnutrición. Esta estrategia ha demostrado ser capaz de alargar la vida en organismos que van desde levaduras hasta humanos ${ }^{11,12}$. 2) Disminución de la señalización en la vía de la insulina (IIS) ${ }^{13-15}$. 3) Reducción de la tasa de respiración mitocondrial ${ }^{16}$.

Fijemos ahora nuestra atención en el cerebro, un órgano sobre el cual el envejecimiento tiene grandes repercusiones. Se ha analizado el perfil de expresión génica en cerebros de humanos, de macacos y de ratones envejecidos de manera conjunta para observar semejanzas y diferencias y poder detectar genes comunes del proceso de envejecimiento y conservados en varias especies ${ }^{17}$. El momento seleccionado por estos autores para tomar las muestras de cerebros envejecidos fue el punto en el cual hay un $25 \%$ de supervivientes de la población original de cada tipo animal. Es importante notar que, de esta forma, la muestra está analizando el perfil transcripcional de la población envejecida más resistente. Con esta estrategia se describieron los genes comunes a estas especies que aumentan o disminuyen su expresión con el envejecimiento. De estos genes comunes, Apolipoproteína $D(A p o D)$ es el gen que más aumenta su expresión en el cerebro envejecido ${ }^{17}$. Se obtuvo idéntico resultado al realizar un meta-análisis de los transcriptomas de distintos tejidos de ratón, rata y humanos envejecidos ${ }^{18}$. Estos resultados convierten a ApoD en una pieza clave en el estudio del envejecimiento y sus mecanismos.

\subsection{ApoD en el envejecimiento y su relación con el estrés oxidativo.}

Después de los datos que acabo de describir, deducimos que de manera general ApoD tiene incrementada su expresión en el envejecimiento y hemos visto que este envejecimiento tiene relación con el incremento de ROS. Este dato podría tener dos interpretaciones, por un lado podríamos pensar que la sobre-expresión de esta proteína podría suceder en respuesta al estrés que se 
genera en la zona y por tanto que pertenece a los mecanismos de protección celular contra el estrés y el daño. Por otra parte este aumento de expresión podría deberse a que esta proteína sea una de las mediadoras del daño o la muerte celular.

Descifrar si ApoD tiene funciones protectoras o no es uno de los objetivos implícitos en todo este trabajo de tesis. Para resolver esta pregunta hemos planteado varios estudios, pero inicialmente en esta introducción voy a contar los aspectos que debemos conocer de ApoD. Desde las partes más moleculares de su estructura, a las patologías con las que ha sido relacionada, así como los aspectos bioquímicos conocidos hasta el momento sobre su mecanismo de acción. Esto nos debe ayudar a contextualizar los estudios realizados y poder saber si la función básica de $A p o D$ es única y generalizable a tejidos y situaciones diversas.

\subsubsection{Biología molecular de ApoD}

ApoD es una glicoproteína secretada que fue inicialmente identificada en el plasma asociada a las lipoproteínas de alta densidad $(\mathrm{HDL})^{19}$ y en una baja proporción en las lipoproteínas de muy baja densidad (VLDL) ${ }^{19}$. El gen tiene una longitud en torno a los $20 \mathrm{kbp}$ y se encuentra situado en el cromosoma 3 (3q26.2) humano y en el cromosoma 16 de ratón. El gen se compone de cinco exones $^{20}$ que dan como resultado un ADN codificante (cDNA) de $855 b^{21}$. En el promotor del gen de $A p o D$ se han predicho e identificado sitios de unión de elementos de respuesta a estrés y de respuesta a hormonas (estrógenos, progesterona y glucocorticoides) entre otros muchos potenciales elementos reguladores $^{22}$.

ApoD es una proteína pleoitrópica. Esto hace referencia a la multitud de tejidos en los que se ha detectado su expresión, además de a la variedad de ligandos y acciones que se le otorgan. Otras apolipoproteinas tienen sus niveles de expresión más elevados en el hígado e intestino, pero ApoD destaca por tener una expresión elevada en páncreas, riñones, testículos, bazo y, sobre todo, en 
el sistema nervioso ${ }^{23}$. En el sistema nervioso principalmente es producida por las células de la glia, concretamente por astrocitos y oligodendrocitos ${ }^{24,25}$.

El polipéptido de $A p o D$ es de 189 aminoácidos, correspondiendo los 20 primeros del extremo N-terminal al péptido señal que codifican la secuencia de exportación de la proteína al lumen del retículo endoplásmico. Este péptido señal será eliminado dando lugar a la proteína madura. ApoD ha sido recientemente cristalizada y su estructura resuelta a $1,8 \AA^{26}$.

Aunque he mencionado que $A p o D$ se describió como parte del complejo de lipoproteínas de las HDL, tras conocerse su secuencia y proponerse su estructura terciaria, fue incluida en la familia de las Lipocalinas ${ }^{21}$. Esta familia se caracteriza por su estructura terciaria altamente conservada compuesta por un barril- $\beta$ formado por 8 láminas- $\beta$ antiparalelas estabilizadas por una hélice- $\alpha$ en la parte C-terminal. El barril- $\beta$ forma una cavidad o bolsillo típicamente delimitado por aminoácidos apolares, lo que permite la unión de pequeños ligandos hidrofóbicos ${ }^{27,28}$.

In vitro se conocen varios ligandos de ApoD: progesterona (con quien ha sido cristalizada; Figura 1$)^{26}$, colesterol $^{29}$, retinol ${ }^{30}$, y ácido araquidónico (AA) (por quien muestra la mayor afinidad) $)^{31,32}$. Únicamente se conoce un ligando fisiológico, el odorante E-3-metil-2-ácido hexenoico $(\mathrm{E} 3 \mathrm{M} 2 \mathrm{H})$ de la piel de la axila humana ${ }^{33}$.
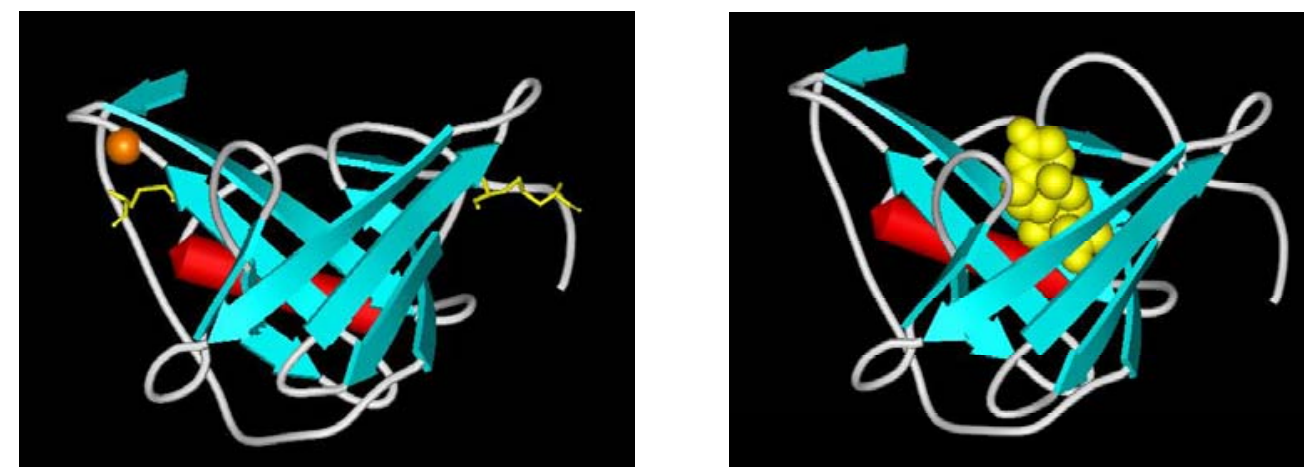

Fig.1. Modelo tridimensional del cristal de ApoD. A: Estructura de ApoD mostrando los puentes disulfuro en amarillo y la cisteína desapareada en naranja. Se observan las láminas beta en azul y en rojo la hélice alfa. B: Estructura de $A p o D$ con el ligando progesterona dentro del bolsillo hidrofóbico (en amarillo). 
ApoD humana (hApoD) presenta dos puntos de glicosilación, en las asparraginas Asn45 y Asn78. La longitud de las cadenas de azucares puede variar considerablemente en función del tejido donde se expresa, por lo que el peso final de la proteína separada en un gel SDS-PAGE puede ir desde los 19 $\mathrm{kDa}$ a los $32 \mathrm{kDa}^{23,33}$. Tiene 5 cisteínas, formando 2 puentes disulfuro y dejando una cisteína, la 116, desapareada. Esta cisteína libre podría conferirle características especiales a la proteína, como sucede en la $\alpha-1$ microglobulina, otra lipocalina que también presenta una cisteína libre y gracias a la cual presenta propiedades reductasa/deshidrogenasa para la eliminación de radicales libres ${ }^{34}$. En el caso de ApoD esta cisteína libre podría formar puentes disulfuro y dar lugar a complejos, como en las HDL donde está asociada a la LCAT y a la Apolipoproteína A-I posiblemente gracias a esa cisteína libre ${ }^{35}$.

\subsubsection{Papel de ApoD y sus genes homólogos en el envejecimiento}

ApoD se sitúa en la base del árbol filogenético de la familia de las Lipocalinas que tienen, como he comentado, una estructura muy conservada ${ }^{20}$ entre ellas aunque no tengan gran similitud de secuencia ${ }^{36}$. Las proteínas de la familia que se encuentran más cercanas a ApoD evolutivamente son las Lipocalinas de insectos, como se puede observar en la Figura 2. Entre ellas podemos destacar Lazarillo, descubierta en saltamontes, y las tres lipocalinas descubiertas en la mosca del vinagre, Lazarillo Glial, Lazarillo Neural y Karl. Algunas de estas proteínas son ortólogos de ApoD y comentaremos también los estudios realizados sobre su relación con el envejecimiento y el estrés oxidativo concomitante.

Lazarillo, es una proteína homóloga de ApoD en el saltamontes Schistocerca americana. Tiene una peculiaridad con respecto a ApoD y a muchas Lipocalinas: No es una proteína libre, se encuentra anclada a la membrana plasmática de las neuronas mediante una cola glicosil-fosfatidil-inositol (GPI) ${ }^{37}$. Los estudios de unión a ligando han demostrado que, al igual que $A p o D$, tiene una gran afinidad por ácidos grasos de cadena larga, entre ellos el $A A^{38}$. 


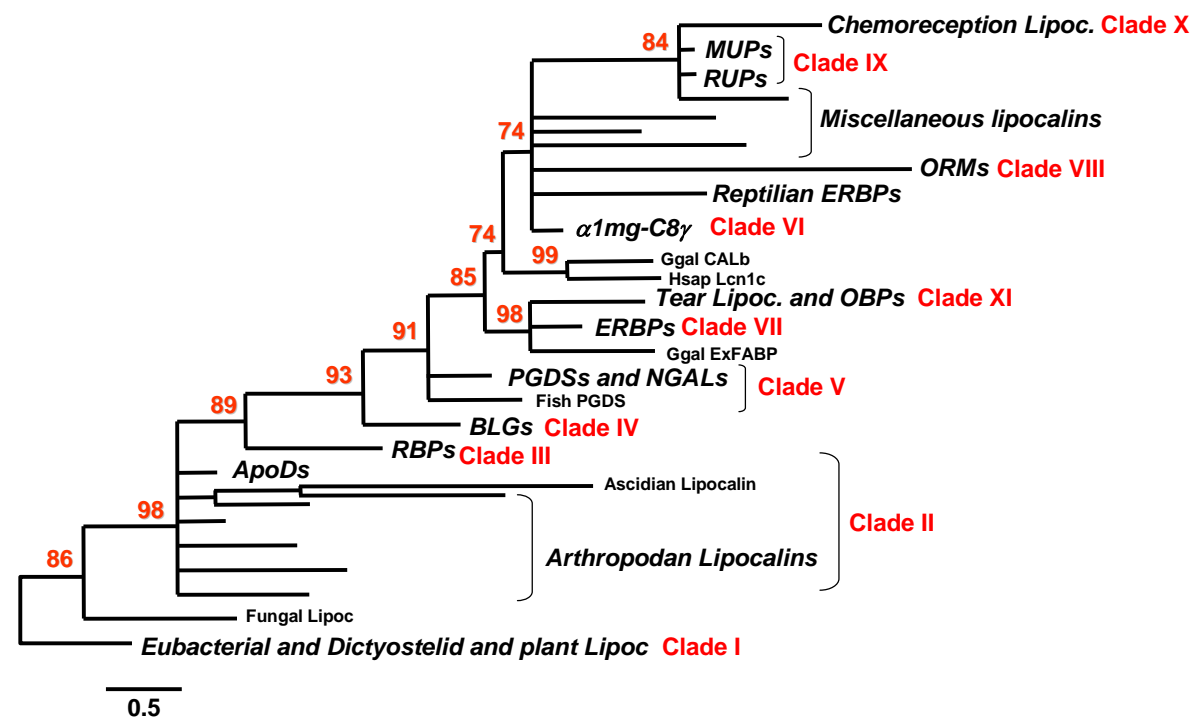

Fig.2. Árbol filogenético de la familia de las Lipocalinas elaborado por el método de máxima verosimilitud.

Se han identificado dos homólogos de ApoD en Drosophila melanogaster: Lazarillo Glial (GLaz) y Lazarillo Neural (NLaz). Reciben estos nombres en base al tipo de células del sistema nervioso que los expresan principalmente. Sin embargo, al igual que ApoD, también se expresan ampliamente fuera del sistema nervioso ${ }^{39}$. Estas dos proteínas son fruto de una duplicación génica y por eso ambas se consideran homólogos de ApoD. Ambas son secretadas.

Para un mejor estudio de la contribución de ApoD y sus homólogos en el envejecimiento se han generado organismos modelo de pérdida y ganancia de función. La caracterización del modelo de pérdida de función para GLaz (GLaz$\mathrm{KO}$ ) ha revelado una importante disminución de la esperanza vida y una mayor sensibilidad al ayuno y a distintos tipos de estrés oxidativo como al agente generador de $\mathrm{ROS}$ paraquat $(\mathrm{PQ})$ y al $\mathrm{H}_{2} \mathrm{O}_{2}$. Además, las moscas GLaz-KO presentan unos niveles mayores de apoptosis neuronal y de lípidos peroxidados $^{40}$. De manera opuesta observamos que la sobre-expresión de GLaz aumenta la longevidad de las moscas y otorga mayor resistencia frente a un potente estrés oxidativo como es la hiperoxia ${ }^{41}$. Se ha observado además que la sobre-expresión de GLaz en células S2 de Drosophila es capaz de aumentar su viabilidad cuando son expuestas a $P Q$ o al péptido $A \beta 42^{42}$ 
implicado en la fisiopatología del Alzheimer y ampliamente utilizado para generar modelos de esta enfermedad.

En cuanto al otro gen homólogo de ApoD en Drosophila, NLaz, recientemente se ha descrito su importante papel en la regulación del metabolismo de la mosca ya que es capaz de reprimir la actividad de la vía de la insulina a nivel de la fosofoinisitol-3-quinasa (PI3K) tanto en el estado de larva y como en el de mosca adulta. Compartiendo características con GLaz, los individuos NLaz-KO tienen una menor esperanza de vida y menor resistencia al estrés, mientras que su sobre-expresión incrementa la resistencia y la longevidad de las moscas $^{43}$.

Otro homólogo de ApoD es la lipocalina de plantas llamada AtTIL presente en Arabidopsis thaliana, que muestra como en los homólogos de insectos un papel protector. Las plantas AtTIL-KO muestran menor resistencia al crecimiento en oscuridad y al tratamiento con PQ. Sin embargo como ocurre en Drosophila con NLaz y GLaz, la sobre-expresión de AtTIL hace a la planta más resistente a los estreses tanto causados por el $\mathrm{PQ}$ como por la luz ${ }^{44}$. El cordado filogenéticamente más antiguo, anfioxus (Branchiostoma belcheri), presenta otro gen homólogo de ApoD, llamado BbApoD que presenta capacidad antioxidante in vitro y que es capaz de evitar el daño oxidativo en el $A D N^{45}$.

El papel de ApoD también ha sido estudiado en mamíferos. Los ratones ApoD$\mathrm{KO}$ muestran una menor resistencia al $\mathrm{PQ}$, un aumento de lípidos peroxidados en el cerebro y un menor éxito en pruebas de locomoción y memoria ${ }^{46}$. Además, estos animales ApoD-KO presentan de manera basal alteraciones en la composición y distribución de varios receptores de neurotransmisores. Presentan menor cantidad de receptores de somatostatina en la capa VI de la corteza, el hipocampo y la sustancia negra pars reticulata ${ }^{47}$, que tiene mucha relación con la enfermedad de Alzheimer. Además en los ratones ApoD-KO también se observa una reducción de los receptores de kainato (receptores ionotropos de glutamato) en la región CA2-3 del hipocampo ${ }^{48}$. El ratón ApoDKO muestra también una recuperación más lenta tras sufrir una lesión en el nervio ciático ${ }^{49}$. 
Todos los datos observados en los homólogos de ApoD muestran un papel en protector que mejora la supervivencia del organismo además de una mejora del tejido en el que se encuentran. La función que realizan, al estar conservada en un espectro tan grande de organismos, debe ser parte de la función ancestral de la familia génica de las Lipocalinas. Dado que parece existir una función común a todas ellas deberían ser capaces de remplazarse funcionalmente unas a otras. Efectivamente la propia hApoD ha sido sobre-expresada en Drosophila $^{42}$ y en el ratón ${ }^{49,50}$. En Drosophila confiere mayor resistencia al estrés, aumentando la longevidad y disminuyendo los lípidos peroxidados ${ }^{42}$. En el ratón se ha demostrado que la sobre-expresión de hApoD en las neuronas es suficiente para aumentar la resistencia del animal completo al tratamiento con $\mathrm{PQ}^{49} \mathrm{o}$ a la infección con coronavirus $\mathrm{OC} 43^{50}$.

Los datos descritos apoyan sólidamente la hipótesis de que ApoD y sus homólogos ejercen funciones protectoras y, por lo tanto, el aumento observado en los organismos envejecidos parece reflejar una respuesta endógena de protección y no uno de los mecanismos causantes del deterioro.

Dado que ApoD parece tener funciones importantes en el proceso de envejecimiento es relevante revisar los trabajos dedicados a estudiar su posible función en el estrés oxidativo que subyace al envejecimiento, así como a las patologías asociadas a él. Profundizaré en la siguiente sección en las asociaciones encontradas entre ApoD y las patologías con alta incidencia en el humano envejecido.

\subsubsection{ApoD en las patologías asociadas al envejecimiento}

Existe un gran número de patologías asociadas a la edad que en los últimos cien años han cobrado gran relevancia debido al aumento en incidencia subsiguiente a un aumento de la esperanza de vida en los países industrializados. Se ha pasado en Estados Unidos del 4,3\% de la población mayor de 65 años en 1910 a un $13.9 \%$ en 2010 , lo que da una idea del impacto socioeconómico que tienen en los países desarrollados estas patologías. 
Estas patologías se pueden agrupar en tres grandes categorías: Enfermedades del sistema nervioso, enfermedades cardiovasculares y metabólicas y, por último, cáncer.

\subsection{3a. Las enfermedades del sistema nervioso}

Las enfermedades del sistema nervioso tienen un gran impacto social, principalmente aquellas que cursan con un déficit cognitivo. Se engloban en este apartado la enfermedad de Alzheimer y la enfermedad de Parkinson, así como las patologías vasculares que tienen lugar dentro del cerebro, como por ejemplo los ictus.

La enfermedad de Alzheimer es una demencia progresiva que lleva a la pérdida de funciones cognitivas del individuo como son la memoria, el lenguaje o la orientación espacio-temporal. Además se deterioran la capacidad ejecutiva, el juicio crítico y el pensamiento abstracto.

A nivel tisular la enfermedad de Alzheimer se caracteriza por la degeneración de neuronas hipocampales y corticales. Se observan ovillos neurofibrilares intracelulares, en los que se encuentra la proteína tau hiperfosforilada y la ubiquitina, y placas de amiloide que son agregados de $\beta$-amiliode extracelulares. El péptido $\beta$-amiliode se forma tras el corte de la proteína precursora del amiliode (APP) por la $\beta$-secretasa y la presenilina que libera pequeños fragmentos insolubles.

En pacientes con Alzheimer, se han detectado niveles elevados de ApoD tanto en líquido cerebroespinal, como en el hipocampo ${ }^{51,52}$, y en el cortex temporal y prefrontal $^{53,54}$. Además se ha comprobado el aumento expresión de ApoD en neuronas del cortex entorrinal de pacientes con Alzheimer, pero no se detecta proteína en las neuronas con ovillos ${ }^{55}$. Esto hace pensar que la expresión de ApoD se incrementa en neuronas estresadas antes de estar verdaderamente dañadas. Por otro lado se ha detectado la presencia de ApoD en los depósitos 
de amiloide de pacientes con Alzheimer ${ }^{56}$. Se ha propuesto que en estos agregados ApoD pudiera ejercer funciones antioxidantes. En estudios de genética humana, se han encontrado algunas correlaciones entre pacientes con Alzheimer y determinados polimorfismos de ApoD en poblaciones de Finlandia, afroamericanos y norte de China ${ }^{57-59}$.

En modelos murinos de Alzheimer también se ha encontrado que ApoD se sobre-expresa ${ }^{60}$. La expresión de ApoD incrementa en hipocampo de los ratones $^{61}$. En este mismo trabajo se vio que también la expresión de ApoD aumenta en cerebros envejecidos, pero en menor medida que en los patológicos.

Varios de estos trabajos que estudian ApoD y Alzheimer han intentado encontrar alguna relación con otra apolipoproteína, la Apolipoproteina E (ApoE), ya que la presencia del alelo $\varepsilon 3$ de la ApoE confiere vulnerabilidad genética al padecimiento de Alzheimer. Los resultados que se obtuvieron indican que no parece existir una relación directa entre ApoD y ApoE, ni en la expresión ni en la localización. Más bien parecen tener distribuciones antagónicas, por lo que se propone que pudieran tener funciones complementarias. Por un lado, ambas apolipoproteínas aumentan con la edad, en enfermedades neurológicas y ante el daño ${ }^{23}$. Por otro, la cantidad de ApoD aumenta en el cerebro de ratones ApoE-KO ${ }^{53}, 62$ pudiendo ser un caso de compensación funcional. Sin embargo, en ratones ApoD-KO, ante una lesión en el sistema nervioso periférico, la expresión de ApoE no aumenta ${ }^{49}$, excluyendo por tanto esta hipótesis de la compensación.

La enfermedad de Parkinson, se caracteriza por la aparición de temblores en reposo, bradiquinesia, rigidez e inestabilidad postural. A nivel de tejido existe pérdida neuronal en la porción compacta de la sustancia negra debido sobre todo a la susceptibilidad de las neuronas dopaminérgicas al estrés oxidativo inherente al catabolismo de la dopamina. Una característica de estas neuronas es que pueden presentar los llamados cuerpos de Lewy, inclusiones intracitoplasmáticas de proteínas del citoesqueleto de la neurona dañada. 
En cerebros de pacientes con Parkinson se han estudiado los niveles de ApoD, detectándose una mayor cantidad de ApoD en la glía que rodea a la sustancia negra de estos pacientes ${ }^{63}$.

Los accidentes cerebro-vasculares tienen mayor incidencia en edades avanzadas ya que los vasos sufren cambios en el endotelio que repercuten en su correcto funcionamiento. Defectos en los mecanismos de vasodilatación y una disminución de la elongación de las células endoteliales pueden llevar a una hipoperfusión cerebral (que contribuye al declive cognitivo). Además, aumentan las moléculas de adhesión en el endotelio y esto trae como consecuencia la inflamación endotelial y, en última instancia, lleva a sufrir ateroesclerosis e ictus ${ }^{64}$.

Se ha estudiado ApoD en un modelo de ictus oclusivo en rata. En este caso se observa como la glía, y principalmente los oligodendrocitos, sobre-expresan $A p o D$ en el área peri-infartada. Posteriormente, varios días tras la reperfusión, la proteína ApoD pero no su ARNm se detecta en el interior de las neuronas piramidales en la zona del infarto. Esto indica que estas neuronas captan ApoD de las células gliales que se acumulan en la escara ${ }^{65}$. Dado que además los niveles de expresión de ApoD aumentan cuando los animales infartados están en un ambiente sensorio-motor enriquecido y esto correlaciona con una mejora en la recuperación del infarto, estos autores proponen que ApoD interviene en la reparación de las sinapsis y en el abastecimiento de colesterol y lípidos para la biogénesis de las membranas, así como para la formación de la escara glial protectora.

Al igual que en el envejecimiento normal, el aumento de ApoD en cerebro parece ser una reacción generalizada ante cualquier tipo de patología o daño en el sistema nervioso. Por ejemplo enfermedades genéticas como NiemannPick $^{66}$, enfermedades infecciosas como el scrapie $^{67}$ o ideopáticas como la esquizofrenia ${ }^{68-70}$, también cursan con un aumento de la expresión de ApoD. Daños en el sistema nervioso central causados por excitotoxicidad con ácido kaínico $^{71}$ o en el sistema nervioso periférico causados por traumatismo ${ }^{49}$ también provocan un aumentos de ApoD. 
Concretamente en los casos de esquizofrenia se ha comprobado que ApoD incrementa con los tratamientos anti-psicóticos. Los pacientes con esquizofrenia tienen alteraciones en la disponibilidad de $A A$, que reduce su acción como segundo mensajero. Estudios en líneas celulares muestran que la sobre-expresión de ApoD incrementa la cantidad de AA que se incorpora en la membrana plasmática, y es capaz de reducir los niveles de AA libre $^{72}$. Estos autores proponen que $A p o D$ podría mejorar la biodisponibilidad de $A A$ en los pacientes esquizofrénicos, disminuyendo así la señalización inflamatoria en los pacientes tratados.

Esta idea de control de la inflamación en el sistema nervioso es lo que se propone como posible mecanismo de acción de ApoD en un modelo de daño en nervio periférico de ratón. La falta de $A p o D$ aumenta la duración y la magnitud de la respuesta inflamatoria retrasando la regeneración ${ }^{49}$. Por lo tanto ApoD parece estar involucrada tanto en el control del estrés oxidativo como de la neuroinflamación, los dos factores comunes al envejecimiento y a las enfermedades del sistema nervioso asociadas a él.

\subsection{3b. Las enfermedades cardiovasculares y metabólicas}

Dentro de las enfermedades cardiovasculares asociadas a la edad encontramos un grupo de enfermedades degenerativas como son algunas valvulopatías degenerativas, la disfunción diastólica cardiaca, la insuficiencia venosa y la arteriosclerosis.

Con el envejecimiento aparecen con frecuencia, además de estas patologías, factores de riesgo para el sistema cardiovascular como la diabetes mellitus, las dislipidemias (hipercolesterolemia, hipertrigliceridemia), la obesidad y la hipertensión arterial. El síndrome metabólico se relaciona con la obesidad siendo el nexo entre la diabetes tipo 2, la dislipidemia y la hipertensión arterial.

ApoD, como componente de las HDL (principalmente) y asociado a la edad ha suscitado hipótesis acerca de su relación con los lípidos y el riesgo 
cardiovascular. Se han detectado variantes alélicas del gen en población africana $^{73}$ con varios polimorfismos consistentes en mutaciones "missense" (Phe36Val, Tyr108Cys, Thr158Lys). Dos de esas variantes están asociadas a factores que elevan el riesgo de sufrir enfermedades cardiovasculares: una de ellas se asocia a reducciones de las cantidades de HDL y ApoA-I y la otra se asocia a elevaciones de los triglicéridos en plasma ${ }^{74}$. Otros estudios epidemiológicos han demostrado una vinculación entre algunos polimorfismos del gen de $A p o D$ con la resistencia a insulina, la hiperinsulinemia, la obesidad y la diabetes mellitus tipo $2^{75-77}$. Por otro lado, en pacientes con infarto de miocardio se ha medido la cantidad de $A p o D$ en sangre y se han detectado niveles más bajos de la proteína que en la población control ${ }^{78}$. En cambio, ApoD ha sido propuesta como biomarcador de la insuficiencia cardiaca terminal, ya que aumenta su expresión en el miocardio de los pacientes con esta patología con respecto a una población sana ${ }^{79}$.

En el ratón se ha demostrado que al sobre-expresar ApoD en el hígado se reduce la concentración de triglicéridos en plasma y si esta manipulación se hace en un modelo de ratón obeso, donde la concentración basal de ApoD aparece disminuida, también se reducen los triglicéridos. En ambos casos parece que la reducción del nivel de los triglicéridos está mediada por el aumento en la actividad de la lipoproteinlipasa $(\mathrm{LPL})^{80}$. Por otro lado, los ratones que carecen de $A p o D$ (ApoD-KO) muestran una disminución de la actividad de la LPL y un aumento de los niveles de triglicéridos, acompañado de hiperinsulinemia ${ }^{81}$. Cuando se sobre-expresa ApoD en el sistema nervioso, los ratones presentan resistencia a insulina ${ }^{82}$.

Curiosamente, al menos parte de estas funciones de ApoD en el control del metabolismo están también conservadas: NLaz en Drosophila ejerce un papel inhibidor de la vía de la insulina ${ }^{43}$. Su sobre-expresión aumenta la concentración corporal de glucosa y su pérdida de función provoca un aumento de grasas neutras, principalmente triglicéridos, y menor cantidad de glucosa y glucógeno $^{43,83}$. 
En la formación de la placa de ateroma en las arterias durante la arterioesclerosis los lípidos juegan un papel importante en el inicio, en la formación de la estría grasa y posteriormente acumulándose y oxidándose al rellenar las células espumosas, pero es también muy importante en este proceso la proliferación de las células de músculo liso de la íntima de las arterias. Las señales descritas como iniciadores de la proliferación son citoquinas y factores de crecimiento secretados por los leucocitos infiltrantes activados por las lipoproteínas (sobre todo LDL oxidadas) que hacen reaccionar al músculo liso vascular. Se ha demostrado, usando células de musculo liso vascular (líneas celulares de rata o cultivos primarios de células humanas), que ApoD es una de los puntos de control que modulan las señales que desencadenan la proliferación de las células de músculo liso durante el proceso de formación de la placa de ateroma ${ }^{84,85}$. La sobre-expresión o adición de ApoD inhibe la respuesta de estas células a señales proliferativas y esta acción es dependiente de la señalización llevada a cabo por la quinasa ERK ${ }^{84}$, 85. Esta quinasa pertenece a la conocida familia de las MAP quinasas que controlan procesos como la supervivencia, la muerte y la proliferación celular.

En animales sometidos a una dieta rica en grasa se ha visto que aumenta la proporción de $A p o D$ en las LDL plasmáticas ${ }^{86}$, lo que podría concordar con la presencia de ApoD en la placa de ateroma observada en humanos.

Aunque como acabamos de ver, existen relaciones muy interesantes entre ApoD y alguna de las enfermedades cardiovasculares asociadas a la edad además de la relaciones entre ApoD con los factores metabólicos de riesgo que se asocian a estas enfermedades, una profundización en estos temas queda fuera de los objetivos de este trabajo. En todo caso, su conocimiento ha inspirado algunos de mis experimentos, concretamente los relacionados con la función de ApoD en la modulación de la proliferación de células cancerosas.

\subsection{3c. El cáncer}

Un desarrollo anómalo e incontrolado de ciertas células por pérdida de los sistemas de control, lleva a la formación de tumores y puede derivar en cáncer. 
Se considera un tumor benigno cuando la proliferación de esas células sucede hasta un punto y no tiene la capacidad de propagarse a otros tejidos. Se considera un tumor cancerígeno cuando las células que proliferan son capaces de invadir y destruir los tejidos. Esta invasión de otros tejidos puede ser tanto de adyacentes o cercanos, como de tejidos muy alejados del tumor original, lo que se conoce con el nombre de metástasis.

La causa de la mayoría de los cánceres es multifactorial y aunque existe un factor de riesgo genético y de inestabilidad genética, una de las mayores contribuciones se las llevan los factores ambientales. Tanto los factores de riesgo como el proceso de tumorogénesis se profundizará un poco más adelante en la introducción dentro del apartado dedicado a al cáncer colorrectal que es el modelo de cáncer que he usado en este trabajo. Una de las razones iniciales por las que estudiar la expresión de $A p o D$ en un tumor, es porque se han descrito muchos tipos en cáncer en los cuales la expresión de ApoD es cambiante con respecto a las personas sanas.

Las primeras observaciones que relacionaron a ApoD con casos de cáncer fue tras analizar y detectar una proteína mayoritaria del fluido quístico que se asocia a la progesterona y que fue nombrada como proteína de 24 kDa del fluido quístico del cáncer de mama (GCDFP-24 o gross cystic disease fluid protein-24) ${ }^{87}$. Pocos años después se comprobó que GCDFP-24 tenía una secuencia aminoacídica idéntica a la proteína descrita como $A p o D^{88}$. Desde ese momento se han realizado estudios tanto en modelos celulares como en pacientes con cáncer de mama. Se ha demostrado que la expresión de ApoD disminuye cuando las células de cáncer de mama aumentaban su proliferación $^{89}$ y que varias moléculas que reducen la proliferación (estradiol, ácido retinoico y 1,25-dihidroxivitamina D3) aumentan la expresión de ApoD ${ }^{90-}$ 93. También se observó una correlación positiva entre la expresión de ApoD y la diferenciación de las células tumorales. Los tumores que presentan una pobre diferenciación, tienen una baja expresión de $A p o D$ y el paciente tiene una supervivencia más baja ${ }^{94}$. 
Con todos estos datos es razonable asociar la presencia de ApoD en el fluido cístico o en las células tumorales con la benignidad del tumor ${ }^{95}$. Se predice un buen pronóstico para los pacientes, incluso cuando existe metástasis en los ganglios linfáticos ${ }^{96,97}$.

A raíz de un estudio de doble híbrido se observó que $A p o D$ se une a la Osteopontina, una proteína pivote en el paso de la proliferación a la metástasis muy importante en el cáncer de mama. La Osteopontina estimula la invasión de las células tumorales por activación de las vías de señalización de ERK1/2 y Akt/PKB, favoreciendo además la invasión porque promueve la sobreexpresión de la metaloproteinasa de matriz-9 (MMP-9) a través de la vía de $N F_{\kappa B}$. Este estudio demuestra que $A p o D$ se une a la Osteopontina bloqueándola e impidiendo la adhesión celular y la proliferación ${ }^{98}$.

Aunque la relación de ApoD con el cáncer de mama ha sido la más estudiada durante años, los estudios se han extendido a otros tipos de cáncer de tejidos diversos. Algunos de los tipos estudiados también son dependientes de hormonas como es el caso del cáncer de próstata. En modelos celulares de cáncer de próstata se ha comprobado que la sobre-expresión de ApoD contribuye a la reducción de la proliferación de las células ${ }^{89}$. Al igual que en el cáncer de mama la expresión de ApoD está relacionada con un buen pronóstico en el cáncer de próstata ${ }^{99}$ y también en carcinomas ováricos ${ }^{100}$.

También se ha estudiado la expresión de $A p o D$ en algunos tumores del sistema nervioso. La expresión de ApoD aumenta en astrocitomas pilocíticos ${ }^{101}$ y en neurofibromas del sistema nervioso periférico, la expresión de ApoD disminuye a medida que avanza la tumorogénesis ${ }^{102}$.

Otro cáncer en el que se ha estudiado la expresión de ApoD es el hepático. Se ha observado que los tejidos hepáticos con cáncer expresan menor cantidad de ApoD y que cuanto más indiferenciados están esos tumores, menor es la cantidad detectada de $A p o D^{103,104}$. En este tipo de tumor ApoD sigue teniendo un valor de buen pronóstico. 
La expresión de $A p o D$ se ha medido también en una línea de cáncer de esófago, donde se reduce la expresión con respecto a las células normales. Todos estos datos han llevado a calificar a ApoD incluso como un gen supresor de tumores por sus efectos en la proliferación ${ }^{105}$.

\subsubsection{ApoD y la proliferación celular}

Como he nombrado en el apartado anterior, los trabajos realizados en células de músculo liso vascular en relación con la placa de ateroma han mostrado que ApoD modula la proliferación celular evitando los efectos de señales proliferativas $^{84,85}$. Por otro lado, en muchos tipos de cáncer hay una clara correlación entre aumentos de ApoD y parada o disminución del crecimiento del tumor. Por esta potencial capacidad antiproliferativa, ApoD ha sido propuesta como posible "tratamiento" anticancerígeno. Y, como hemos visto anteriormente, su aumento en un tumor es indicador de buen pronóstico en muchos tipos de cáncer ${ }^{94-97,99-101,103-107 .}$

Por otro lado, en situaciones de cultivo celular, determinados tipos de células cuando entran en un estado de quiescencia (situación de parada del crecimiento denominada "growth arrest"), comienzan a sobre-expresar ApoD sin necesidad de cualquier otro estímulo $22,23,91,98,102,108-110$

Esta interesante relación entre la situación celular de proliferación o quiescencia y el patrón cambiante de expresión de ApoD, es lo que suscitó el estudio de ApoD durante el transcurso de esta tesis en dos modelos opuestos: un modelo de células básicamente post-mitóticas y quiescentes (sistema nervioso) confrontado con otro modelo de células proliferativas (cáncer colorrectal). El objetivo global es intentar encontrar semejanzas y diferencias entre ellos que nos acerquen a un conocimiento profundo de la función de ApoD. 


\subsubsection{ApoD y el estrés oxidativo}

Para la función bioquímica de $A p o D$ se tienen varias hipótesis, pero en realidad aún se desconoce su forma de acción. Las relaciones con el envejecimiento y sus cambios de expresión con un grupo tan amplio de patologías nos hace cuestionar ¿Qué tienen en común todas estas situaciones? Ante esta pregunta surge un candidato claro: en todos estos casos aparece estrés oxidativo, ya sea como origen o causa primera, o como consecuencia secundaria del deterioro tisular.

Además de las correlaciones con las distintas situaciones donde ocurre estrés oxidativo, los siguientes antecedentes apuntan a una relación causa-efecto directa entre ApoD y el estrés oxidativo. ApoD tiene efectos protectores sobre la supervivencia del organismo, tanto en ratones como en moscas, cuando se someten a estrés oxidativo inducido con $P Q$ y la expresión de $A p o D$ ayuda a mantener la homeostasis del tejido nervioso en estas situaciones. Este efecto es realizado por ApoD mediante el mantenimiento de niveles bajos de peroxidación lipídica ${ }^{40,43,46}$. Por otro lado existen evidencias directas de que ApoD puede llevar a cabo reacciones antioxidantes en sistemas in vitro ${ }^{45,111}$.

El diseño de este trabajo pretende dilucidar la función de $A p o D$ en células sometidas a estrés oxidativo y llegar a comprender si dicha función es generalizable entre distintos tipos celulares y situaciones patológicas muy heterogéneos, ya que la homeostasis celular y tisular podría ser muy diferente en situaciones de proliferación o de quiescencia.

Mi estudio se centra en dos tejidos y situaciones patológicas diferentes: el sistema nervioso sometido a estrés oxidativo experimental y el cáncer de colon, ambos paradigmas de gran interés biomédico. Además, para tener una comprensión completa de la función de $A p o D$, es importante el estudio de sus funciones en condiciones no patológicas, un aspecto también abordado en mi trabajo. 


\subsection{Funciones de ApoD en el sistema nervioso}

\subsubsection{El sistema nervioso y su vulnerabilidad al estrés oxidativo.}

El estudio del sistema nervioso ha sufrido un avance muy rápido en el último siglo ya que debemos pensar que hasta principios del siglo $X X$ ni siquiera se conocía si este tejido estaba formado por células como unidad fundamental. Con el desarrollo de nuevas técnicas de tinción celular y la avance de las técnicas de visualización, el neuroanatomista Santiago Ramón y Cajal junto con el neuropatólogo Camilo Golgi y el fisiólogo Charles Sherrington, pusieron de manifiesto que el tejido nervioso está compuesto por células que llamaron neuronas, unidas entre ellas formando un entramado y comunicadas entre sí por contactos especializados llamados sinapsis. El trabajo fue reconocido con el premio Nobel de Fisiología y Medicina de 1906 conjunto para Cajal y Golgi.

El tejido nervioso está formado por dos categorías de células divididas en células nerviosas y células gliales (Figura 3).

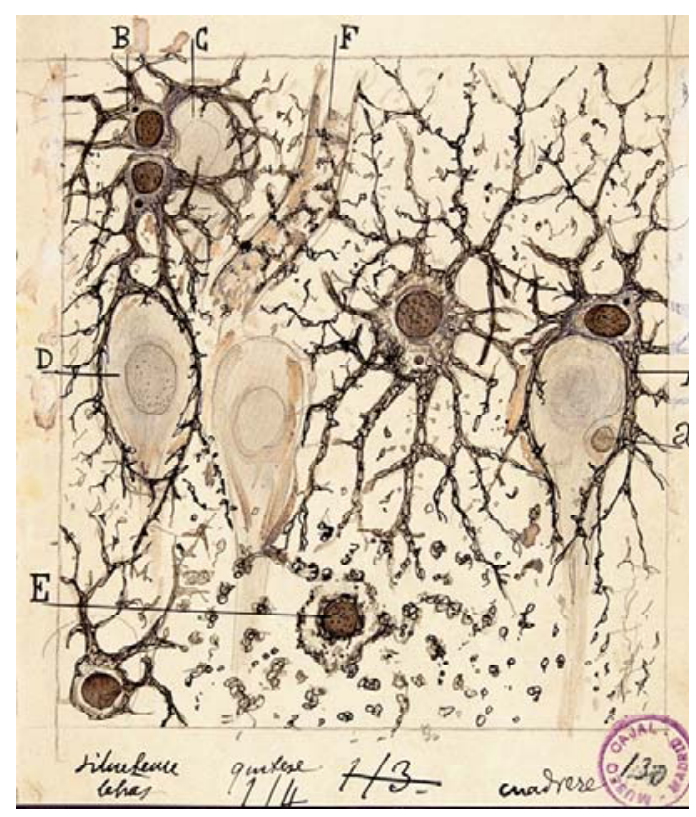

Fig.3. Ilustración de Cajal mostrando a los astrocitos en sus múltiples papeles en el sistema nervioso, como por ejemplo, la asociación de sus pies terminales a los vasos sanguíneos. Destaca su capacidad de división y su íntima relación con las neuronas. 
Kandel et al. ${ }^{112}$ y Purves et al. ${ }^{113}$ resumen muy bien las propiedades de las células que forman parte del sistema nervioso. Las neuronas están definidas morfológicamente por varias partes; el cuerpo celular, las dendritas y el axón que, dependiendo del tipo de neurona, tienen un tamaño y forma concreta. Los procesos de exocitosis y endocitosis que subyacen a la continua comunicación sináptica entre neuronas se controlan correctamente gracias al buen funcionamiento del citoesqueleto, los orgánulos y los componentes de las membranas. La arborización más o menos compleja de las neuronas depende del número de contactos sinápticos de cada célula. La transmisión sináptica es el proceso químico y eléctrico por el cual la información codificada por los potenciales de acción es transmitida de una célula a la siguiente. Las sinapsis químicas se llevan a cabo liberando vesículas de neurotransmisor desde el terminal presináptico a la hendidura sináptica, para unirse a receptores específicos presentes en el terminal postsináptico. Esta unión provoca cambios en las propiedades eléctricas de la membrana de la célula diana.

El término de célula glial es un concepto amplio que hace referencia al origen griego de la palabra glía que significa "liga" o "pegamento", en el cual encajan varios tipos celulares atendiendo a la función de sostén o acompañamiento que inicialmente se le otorgó a estas células. Fue Ramón y Cajal quien identificó a las células gliales como parte del tejido nervioso, diferenciándolas de las neuronas. Además tras sus trabajos se les reconoció una función activa y no sólo de sostén. Existen tres tipos de células en el SNC: astrocitos, oligodendrocitos y células microgliales. Los astrocitos tienen prolongaciones que les confieren un aspecto estrellado (de ahí el prefijo "astros") y que desempeñan una variedad de funciones que más tarde comentaré más detenidamente, entre las que destaca la de un mantenimiento apropiado de la señalización y transmisión de información entre neuronas. Los oligodendrocitos depositan una envoltura laminada y rica en lípidos llamada mielina alrededor de algunos axones. La mielina tiene efectos importantes sobre la velocidad de transmisión de señales eléctricas. En el SNP las células que elaboran mielina son las células de Schwann. Las células microgliales fueron diferenciadas del resto de células gliales gracias a los estudios de Pío 
del Río Hortega, que además describió sus funciones fagocíticas en diferentes procesos patológicos. La microglia tiene un origen mesodérmico (en contraste con el resto de tipos celulares del sistema nervioso que tienen un origen embrionario ectodérmico), derivan de los precursores hematopoyéticos y comparten muchas propiedades con los macrófagos. Su función principal es limpiadora, eliminando restos celulares de sitios de lesión o de recambio celular normal. Además liberan, al igual que sucede con los macrófagos, una amplia gama de citoquinas que señalizan y modulan la inflamación local, influyendo en la supervivencia o muerte celular.

Las células del sistema nervioso están expuestas a una fuerte y constante de producción ROS y RNS, debido a un metabolismo muy demandante. Esta carga oxidativa está estrechamente regulada dentro de unos límites sostenibles gracias a la acción de un conjunto muy eficaz de proteínas y compuestos antioxidantes. Sin embargo como ya he comentado, durante el envejecimiento fisiológico $\mathrm{o}$ en determinadas enfermedades genéticas o esporádicas el sistema nervioso se ve afectado por factores que incrementan la degeneración debido a un aumento en la producción y/o una reducción en la eliminación de ROS. El estrés oxidativo que se genera, subyace claramente a los mecanismos patogénicos.

Como una manera de estudiar los mecanismos antioxidantes que participan en la regulación homeostática del sistema nervioso, se han usado varios métodos de inducción de ROS. Algunos de estos métodos incluyen tratamientos con fármacos como MPTP, maneb o $\mathrm{PQ}$, que en organismos modelo son capaces de imitar, total o parcialmente los signos y síntomas de la enfermedad de Parkinson ${ }^{114}$. La extensa obra de varios grupos de investigación con estos compuestos, ha contribuido a descubrir el proceso detallado de la respuesta que tiene el sistema nervioso ante el estrés oxidativo inducido experimentalmente. El tratamiento crónico con dosis subletales de estos compuestos provoca respuestas específicas que son generadas por los diferentes tipos celulares implicados. La expresión génica de las respuestas tempranas que se desencadenan ante el PQ se han publicado en los tejidos no 
neuronales ${ }^{115-118}$, pero no existe ningún estudio realizado en el sistema nervioso.

El sistema nervioso está protegido por una serie de barreras (barrera hematoencefálica en el SNC y barrera nervio-sangre en el SNP) que impiden o inhiben el paso de muchas sustancias, entre ellos los xenobióticos, desde la sangre al tejido nervioso. La barrera hematoencefálica es menos permeable, tiene mayores sistemas de control para regular lo que pasa desde la sangre al parénquima encefálico. Esto ha de tenerse en cuenta cuando el estrés oxidativo experimental se administra desde fuera del sistema nervioso. Prasad et al $\left({ }^{119}\right)$ han estudiado de forma muy detallada cómo se acumula el PQ en distintas regiones cerebrales tras inyectarlo intraperitonealmente en el ratón. Por otro lado, las barreras limitan también la capacidad de los antioxidantes clásicos para alcanzar concentraciones suficientes en el sistema nervioso que se podrían ayudar a aliviar el exceso de ROS en el tejido.

Como he comentado anteriormente, nuestro laboratorio estudia desde hace años el papel del gen de ApoD y sus ortólogos en Drosophila melanogaster dentro del sistema nervioso. Utilizando el estrés oxidativo inducido de manera experimental por el tratamiento con $P Q$, hemos demostrado que ApoD tiene efectos protectores sobre la supervivencia del organismo, tanto en ratones como en moscas, y que ayuda a mantener la homeostasis del tejido nervioso mediante el mantenimiento de bajos niveles de peroxidación lipídica ${ }^{40,43,46}$. La expresión del ARNm de ApoD es transitoria e inducida en el cerebro del ratón ante el tratamiento con PQ mostrando un pico temprano de expresión a las 3 horas tras dicho tratamiento. Esta sobre-expresión es específica para el tejido nervioso ${ }^{46}$. Sin embargo, aún falta por saber, si alguno de los tipos celulares del sistema nervioso es responsable de estas respuestas al estrés oxidativo y de los efectos protectores resultantes.

EI PQ (1,1-dimetil-4, 4-bipiridinio) generador de ROS que he venido nombrando durante buena parte de esta introducción, es un herbicida no selectivo usado ampliamente en agricultura que emergió como uno de los posibles factores de riesgo ambiental asociado al origen de la enfermedad de Parkinson. Se 
propuso, dada la gran similitud estructural de la molécula de $\mathrm{PQ}$ con el $\mathrm{MPP}^{+}$, que es el metabolito activo del MPTP (identificado como neurotoxina inductora de Parkinson).

Las exposiciones a PQ han demostrado su asociación con el Parkinsonismo, tanto en agricultores expuestos a este herbicida como en animales de experimentación (tanto roedores, como primates). El mecanismo de toxicidad del $P Q$ ha sido investigado en muchos estudios que muestran su relación con la producción de ROS y los efectos de estos ${ }^{120}$. Se ha demostrado que la producción de ROS por el PQ está mediada por la acción de la SOD y que los signos de parkinsonismo se deben a la pérdida selectiva de neuronas dopaminérgicas en el cerebro ${ }^{121}$. El esquema que resume cómo se generan los ROS en una célula por acción del PQ se puede observar en la Figura 4.

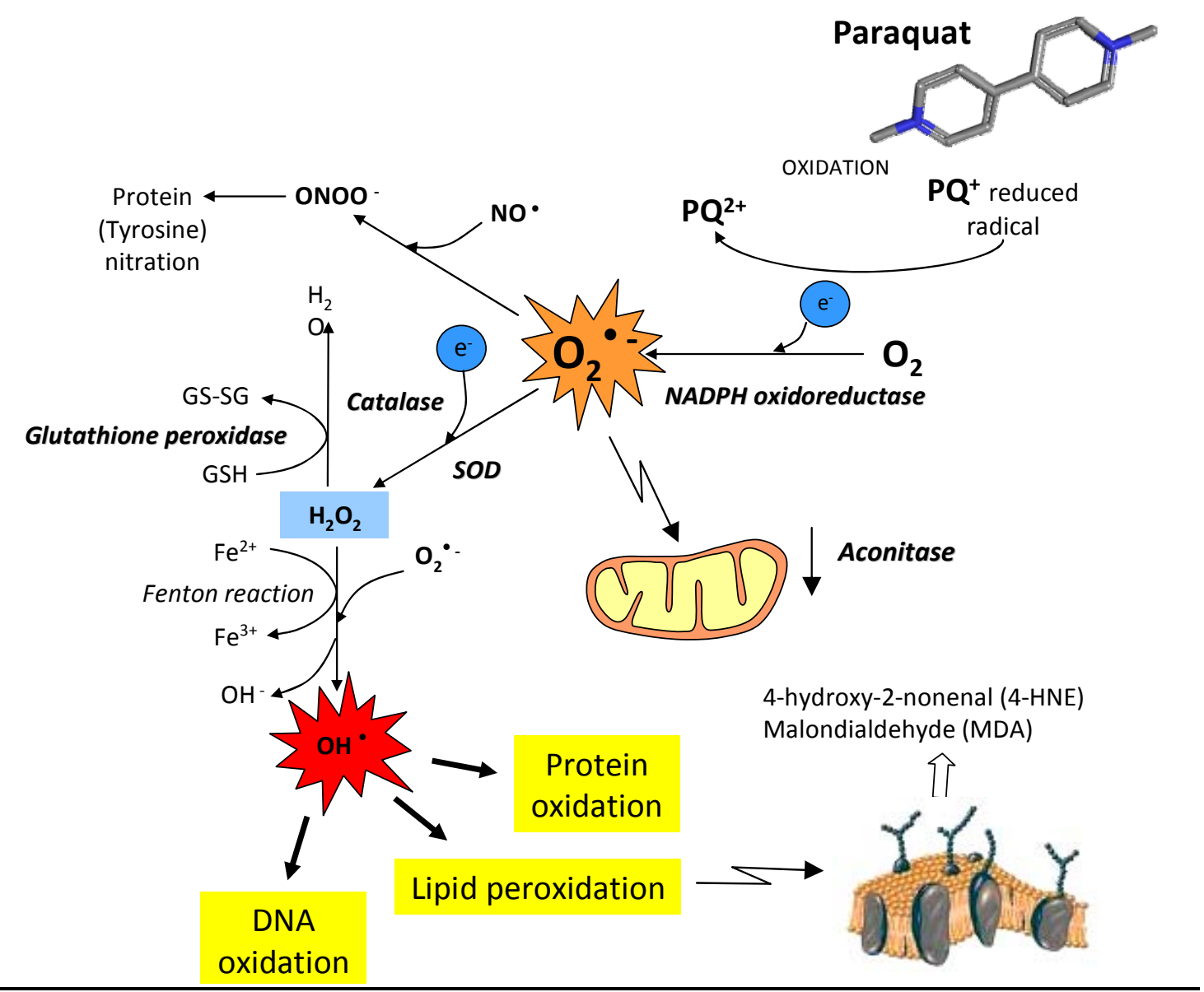

Fig.4. Generación de ROS inducida por $P Q$ en una célula. Reacciones de oxidorreducción que producen radicales libres y llevan al daño en las proteínas, los lípidos y el ADN. 


\subsubsection{ApoD y el cerebelo}

El cerebelo se encuentra situado posteriormente en la cara dorsal del troncoencéfalo y sus funciones mas conocidas consisten esencialmente en la coordinación y planificación del movimiento y el aprendizaje de las tareas motoras además del almacenamiento de esa información.

El cerebelo está dividido desde un punto de vista estructural en la corteza cerebelosa y en núcleos cerebelosos profundos que son una agrupación subcortical de células situado hacia por debajo de esa corteza.

Las vías aferentes que alcanzan el cerebelo desde otras regiones encefálicas envían ramas tanto a los núcleos profundos como a la corteza cerebelosa. Las vías eferentes del cerebelo se originan desde las células de Purkinje situadas en la corteza cerebelosa y se dirigen a las células de los núcleos cerebelosos profundos, para desde allí abandonan el cerebelo y regulan la actividad de las neuronas motoras superiores de la corteza motora y premotora y de los núcleos del tronco del encéfalo. Al igual que sucede en los ganglios basales, se produce un asa que recibe proyecciones desde la corteza cerebral y el tronco del encéfalo y envía nuevamente proyecciones hacia ellos. De este modo la función primaria del cerebelo es detectar la diferencia o el "error motor", entre el movimiento que se intentó y el movimiento que se ha realizado. Las correcciones que lleva a cabo el cerebelo para reducir este error pueden suceder durante el curso del movimiento o pueden ser almacenadas como aprendizaje motor hasta una nueva realización del movimiento.

En el sistema nervioso varios tipos celulares han mostrado mayor vulnerabilidad al estrés oxidativo. Entre ellos se encuentran células del hipocampo, células de la sustancia negra y las células de los granos del cerebelo.

Las neuronas de los granos del cerebelo constituyen la mayor población homogénea del cerebro de los mamíferos y son un modelo bastante elegido 
para el estudio de los mecanismos celulares y moleculares de la neurodegeneración y la neuroprotección. Se ha observado que estas células de los granos del cerebelo son sensibles al $P Q$, dónde se producen ROS a través de la xantina oxidasa. Este enzima media la liberación del citocromo c desde la mitocondria que desencadena una apoptosis mediada por la activación de caspasa 3 en el citoplasma y lleva a la fragmentación del ADN y la consiguiente muerte celular. Este proceso tiene lugar rápidamente, en unas 24 horas de tratamiento $^{122}$.

El cerebelo siendo una región sensible al estrés oxidativo, resulta ser también una de las regiones que sufre alteraciones con el envejecimiento y en el que tienen lugar muchas neuropatologías ${ }^{123}$.

ApoD se expresa dentro del cerebelo tanto en los astrocitos como en los oligodendrocitos $^{124}$, y el mutante con pérdida de función de ApoD muestra defectos motores en pruebas de comportamiento ${ }^{46}$.

Teniendo en cuenta todos estos detalles a cerca de la vulnerabilidad del cerebelo al estrés oxidativo y la manera en la que se afecta cuando no está presente $A p o D$, decidimos analizar en la primera parte de este trabajo el perfil transcripcional que muestra el cerebelo de ratones sometidos a un tratamiento con $P Q$. Se usaron ratones de varios genotipos (silvestre, o WT, mutante nulo para ApoD, o ApoD-KO, y mutante de sobre-expresión o Tg-hApoD) para comprender qué sucede en las células del cerebelo pocas horas después de recibir un estímulo que genere un estrés oxidativo y de qué manera influye la presencia de ApoD en el tejido.

\subsubsection{ApoD y los astrocitos}

Los astrocitos componen el $25 \%$ de las células y el $35 \%$ de la masa del SNC. Los papeles que desempeñan los astrocitos en el SNC sano son muchos y diversos. Dentro de sus actividades normales se engloban interacciones importantes con neuronas, oligodendrocitos, microglia y células endoteliales. Funciones conocidas de los astrocitos desde hace muchos años incluyen el 
soporte metabólico para las neuronas, aportando lactato como fuente energética principal, así como el control local del flujo sanguíneo, actuando a través de sus pies en contacto con los vasos sanguíneos. Otra función es la de mantener el ambiente extracelular, controlando la concentración de neurotransmisores sobre todo de la hendidura sináptica, amortiguando la concentración de iones extracelulares como $\mathrm{K}^{+}, \mathrm{H}^{+}$y $\mathrm{Ca}^{2+}$, además de desintoxicar de amonio, drogas, fármacos y hormonas. Incluso controla el secuestro de metales y radicales libres. Otras funciones clásicamente conocidas que tienen son la guía de determinadas neuronas durante el desarrollo y funciones en inmunidad e inflamación ${ }^{125}$. Recientemente se han ampliado estas funciones, gracias al descubrimiento de su participación en el procesamiento de la información y la plasticidad sináptica. Ha dejado de verse a los astrocitos como participantes pasivos en la función sináptica, para demostrar que existe una dinámica bidireccional en la comunicación entre la glía y las neuronas dentro de la sinapsis ${ }^{126}$.

Inicialmente se realizaron experimentos para demostrar que los astrocitos in vitro respondían elevando el $\mathrm{Ca}^{2+}$ intracelular ante diversos neurotransmisores, tanto de señales excitadoras como inhibidoras, iniciadas por el glutamato, el GABA, el ATP o la acetilcolina entre otros ${ }^{127}$. A continuación se comprobó en preparaciones de hipocampo que tras una estimulación eléctrica en las neuronas se producían elevaciones de la concentración de $\mathrm{Ca}^{2+}$ en los astrocitos circundantes, mediadas tanto por receptores de glutamato ${ }^{128}$, como por receptores de GABA tipo $\mathrm{B}^{129}$ y receptores muscarínicos de acetilcolina $^{130}$. Los neurotransmisores liberados por la neurona presináptica producen incrementos de $\mathrm{Ca}^{2+}$ en la glía adyacente y esta glía activada libera transmisores que incluyen el glutamato, el ATP y la D-Serina.

Para diferenciarlos de los producidos por las neuronas, a estos transmisores se les conoce con el nombre de gliotransmisores ${ }^{131}$. Dichos gliotransmisores ejercen un efecto de potenciación o depresión sobre el terminal presináptico que afectan a futuras liberaciones de neurotransmisor. Además tienen efecto estimulador directamente sobre el terminal postsináptico produciendo también respuestas excitatorias o inhibitorias. Basándonos en todos estos nuevos 
datos, los astrocitos y la glía en general deben considerarse como participantes activos de la sinapsis y reguladores dinámicos de la transmisión sináptica.

Se acuño el término de "sinapsis tripartita"131-133, para destacar la función del astrocito como participante activo de la sinapsis. Los astrocitos son también responsables de modular la comunicación entre neuronas a mayores distancias para lo cual utilizan el sistema de endocannabinoides ${ }^{134}$. Además los astrocitos introducen una nueva posibilidad en la codificación de las señales del sistema nervioso, ya que son capaces los astrocitos de cambiar la polaridad de señal $^{135}$.

Este versátil tipo celular es, además, la célula más resistente del SNC. Los astrocitos son especialmente duraderos cuando nuestro cerebro envejece ${ }^{136}$ y son extremadamente resistentes a las diversas formas de daño tisular y celular que se producen cuando el sistema nervioso central sucumbe a la enfermedad. Los astrocitos responden a la patología en el SNC con una transformación fenotípica conocida como astrogliosis reactiva, que implica una reorganización de su perfil de expresión génica y les conduce a un profundo cambio en la morfología y en sus capacidades de migración y proliferación ${ }^{137}$. La astrogliosis está caracterizada por la rápida síntesis de la proteína acídica fibrilar glial (GFAP), de los filamentos intermedios del citoesqueleto, además de citoquinas y factores de crecimiento. Se sabe que durante el envejecimiento normal los astrocitos senescentes se vuelven más fibrosos, incrementando su tamaño y la expresión de GFAP. En casos extremos esta astrogliosis deriva en la formación de una placa o escara que contiene la acción negativa de un daño y limita su radio de afectación. La reactividad de los astrocitos puede ser considerada un arma de doble filo: desencadena un mecanismo de protección que puede llegar a ser peligroso si queda fuera de control. Estamos empezando a comprender muchas de las señales moleculares y procesos que ponen en marcha la reactividad de los astrocitos ${ }^{138}$. Sin embargo, el conocimiento de los mecanismos que restringen el alcance de la astrogliosis y que controlan su resolución (su vuelta atrás o finalización) es escaso y fragmentado. La importancia de estos mecanismos posteriores a la activación se pone de 
manifiesto con el hecho de que muchas situaciones patológicas son causadas por defectos en los mecanismos que deben parar la reactividad glial.

El estrés oxidativo, un fenómeno concomitante a la mayoría de las formas de daño en el SNC y la neurodegeneración, es un estímulo muy conocido para activar la reactividad de astrocitos.

ApoD se produce principalmente por los astrocitos y los oligodendrocitos dentro del SNC, por ello una de las partes importantes de este trabajo se centra en el estudio de este tipo celular concreto. Hipotetizamos que ApoD podría ser una de las proteínas que forme parte del buen sistema defensivo que poseen los astrocitos que les hace ser una célula tan resistente. Además pensamos que ApoD no sólo ayudaría de manera autocrina a la glía, si no que podría formar parte del sistema defensivo que secreta el astrocito para acudir al rescate de las neuronas adyacentes que se encuentren sometidas a un daño.

\subsubsection{ApoD y el sistema dopaminérgico}

La vía nigroestriatal está compuesta por un sistema de fibras dopaminérgicas que van principalmente desde la sustancia nigra pars compacta (SNpc), donde se sintetiza el neurotransmisor, hasta el cuerpo estriado (núcleos caudado y putamen). Esta vía está integrada en los circuitos de los ganglios basales que controlan la función motora a través de una compilación de información proveniente de casi todas las áreas de la corteza cerebral que convergen en los ganglios basales para terminar controlando a las neuronas motoras del área motora del córtex frontal. Las lesiones en este circuito comprometen la iniciación y la ejecución de los movimientos voluntarios como ejemplifican la enfermedad de Parkinson y la de Huntington ${ }^{139}$.

La dopamina es un neurotransmisor enclavado en el grupo de las aminas biógenas (junto con la serotonina y la histamina) y dentro de ellas, por su estructura molecular, en las catecolaminas (dopamina, noradrenalina y adrenalina) porque comparten el grupo catecol. Todas ellas tienen un efecto excitador en el terminal postsináptico. El precursor molecular de las 
catecolaminas es el aminoácido tirosina y, para sintetizarlas, el primer paso que sufre este aminoácido es una reacción de oxidación llevada a cabo por el enzima tirosina hidroxilasa. Este enzima es el enzima limitante en la vía y produce dihidrofenilalanina (DOPA). La dopamina está presente en gran parte del sistema nervioso (Figura 5), con una gran cantidad en el cuerpo estriado, pero también en muchas regiones del córtex.

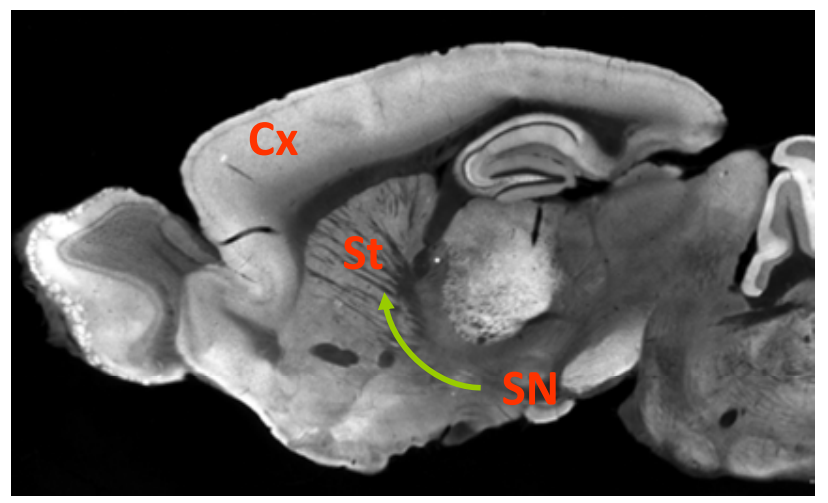

Fig.5. Distribución principal de la dopamina en el sistema nervioso central. Imagen mostrando la principal vía, la nigroestratal. Imagen modificada de Kalla et al. $(2006)^{140}$.

Tras ser sintetizada en el citoplasma de la neurona, la dopamina se carga en vesículas a través de un transportador para ser liberadas posteriormente. Una vez liberado en la hendidura sináptica, el exceso de neurotransmisor que no se haya unido a los receptores debe ser retirado y esto se lleva a cabo por un transportador denominado DAT (transportador de dopamina $\mathrm{Na}^{+}$-dependiente) que está presente tanto en neuronas como en astrocitos. Por esta razón también existen enzimas del catabolismo dopaminérgico tanto en neuronas como en astrocitos. Dichas enzimas catabólicas son la monoaminooxidasa (MAO) y la catecol O-metil-transferasa (COMT) (Figura 6) que liberan como producto de reacción peróxido de hidrógeno lo cual induce un estrés oxidativo en los tipos celulares en los que se degrada la dopamina en situaciones fisiológicas normales. 


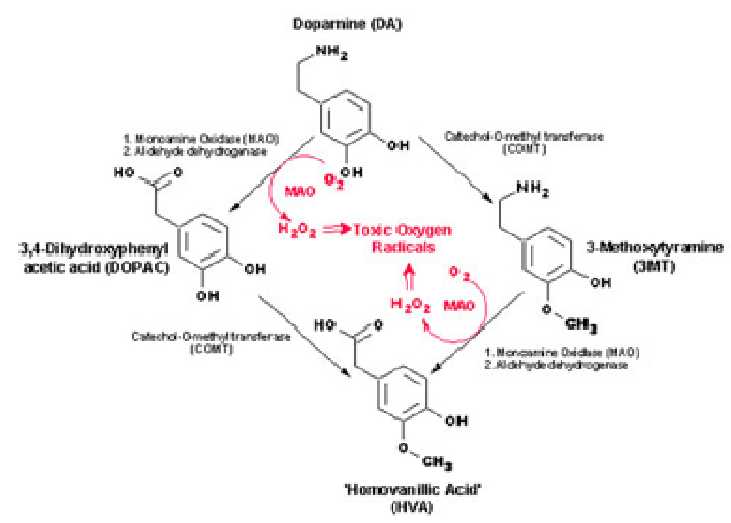

Fig.6. Vías de degradación de la dopamina. Se muestran los enzimas, productos de reacción (radicales libres) y los productos de degradación final de la dopamina al ácido homovalínico.

Por lo tanto, el estrés oxidativo que tiene lugar en el cerebro es especialmente prominente en los sistemas dopaminérgicos, ya que como acabo de nombrar, son lugares ya sometidos a un estrés basal debido al catabolismo de la dopamina que inevitablemente incrementa los niveles de los ROS. Cualquier estrés externo que se añada hace que las células sufran más y deben intentar contrarrestarlo a nivel local con mecanismos antioxidantes ${ }^{141}$. Las neuronas son células que no están bien adaptadas para combatir el estrés oxidativo en comparación con otros tipos celulares, de modo que los astrocitos, dado que si están provistos de enzimas y sistemas antioxidantes, son claros candidatos a desempeñar un papel importante no sólo en el mantenimiento de los sistemas dopaminérgicos en el cerebro sano, sino también en el cerebro afectado por la enfermedad de Parkinson. La respuesta astroglial está siendo estudiada en profundidad en los pacientes con enfermedad de Parkinson y en modelos animales de esta enfermedad ${ }^{142,}{ }^{143}$, aunque todavía estamos lejos de entenderla por completo.

Como se comentó en la sección 1.2.3a, un sello patológico de la enfermedad de Parkinson es la presencia en las neuronas de la $\mathrm{SN}$ de unas inclusiones en el citoplasma llamadas cuerpos de Lewy. Estos agregados contienen Parkina y Sinucleína ${ }^{144}$. Se cree que la presencia de parkina en los cuerpos de Lewy tiene un efecto protector ante la neurotoxicidad que generan las proteínas mal plegadas. Parkina, con su función de ubiquitinación, estaría intentando retirar 
esas proteínas mal plegadas para que se degradasen, pero, a la vez, se produce un estrés de retículo en esas neuronas ${ }^{145,146}$.

A pesar del avance en los detalles de la enfermedad, su etiología todavía no se comprende totalmente y probablemente es multifactorial, uniéndose una base genética a factores ambientales ${ }^{147}$. En los últimos años, se han realizado estudios que han proporcionado nuevos e importantes conocimientos sobre la implicación de la genética en la patogénesis de la enfermedad de Parkinson. Entre los alelos asociados al Parkinson familiar, se encuentran las mutaciones en Parkina que son la causa más común del parkinsonismo autosómico recesivo juvenil $^{148}$.

Otros genes implicados en la etiopatogenia de la enfermedad con componente genético recesivo son PINK1 (del inglés, PTEN-induced novel kinase 1, nueva quinasa 1 inducida por PTEN) y DJ-1 (proteína del Parkinson 7). Todos ellos involucrados en la disfunción mitocondrial y la protección al estrés oxidativo ${ }^{149}$.

Los tres genes ejercen un impacto funcional sobre las mitocondrias, PINK-1 $1^{150 \text {, }}$ ${ }^{151}$, DJ-1 ${ }^{152,153}$ y Parkina ${ }^{154-156}$ influyendo en la sensibilidad de las neuronas dopaminérgicas a las toxinas como la rotenona o MPTP. En los ratones KO de PINK-1 y Parkina no se pierden neuronas dopaminérgicas, pero hay evidencias de alteración de la función mitocondrial ${ }^{157,}{ }^{158}$. También sucede el mismo defecto en las mitocondrias de líneas celulares que tienen silenciado el gene PINK-1 ${ }^{159}$.

Uniendo la susceptibilidad de las neuronas dopaminérgicas, por su propio metabolismo, al estrés oxidativo originado con el envejecimiento, la acción de determinados agentes ambientales tóxicos y una susceptibilidad genética, podemos imaginar el contexto ideal para que suceda una enfermedad en que afecte de forma especial a estas neuronas. Reducir o controlar el estrés oxidativo sufrido por las neuronas dopaminérgicas a través de la acción de ApoD podría proporcionar una solución a esta patología. 


\subsection{La mucosa intestinal, el cáncer colorrectal y el estrés oxidativo}

El colon es la región del intestino grueso subdividida en el ciego y las porciones ascendente, transversa y descendente. El colon sigmoideo o sigma es el asa que comienza en el reborde pélvico y va hasta la cavidad peritoneal para convertirse en el recto (Figura 7A). La función del colon es la de absorción de agua y electrolitos desde la luz y, a diferencia de la mucosa del intestino delgado, la del colon no tiene vellosidades y es plana. Está punteada por numerosas criptas tubulares rectas que se extienden hacia el interior hasta la capa muscular de la mucosa. El epitelio superficial está compuesto por células absortivas columnares, que tienen microvellosidades más cortas y menos abundantes que las del intestino delgado, además de células mucosas. Las criptas contienen abundantes células mucosas caliciformes, células endocrinas y células madre (Figura 7B).

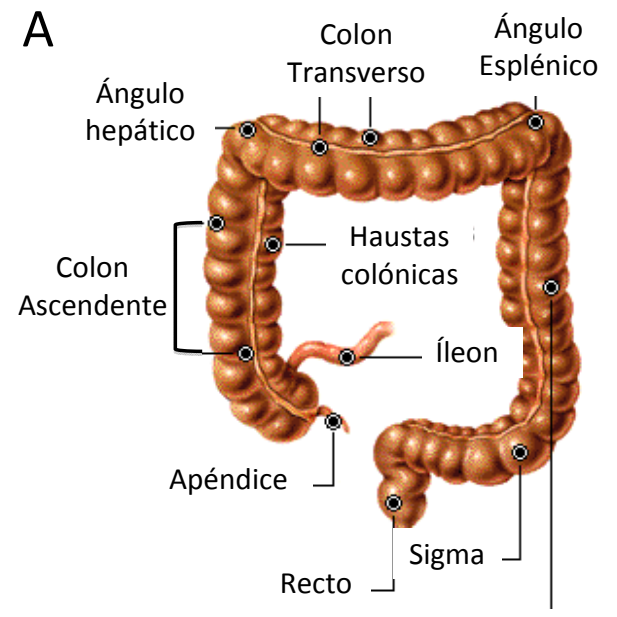

B

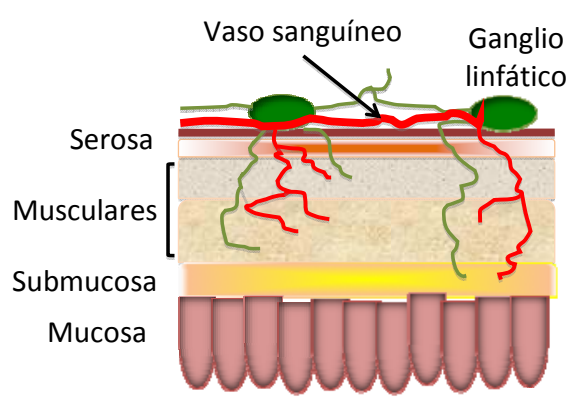

Fig.7. Colon y mucosa colónica. A: Partes y estructura del colon humano. B: Diferentes capas que componen la histología del colon.

La capacidad de regeneración del epitelio intestinal es notable. La proliferación se lleva a cabo en las criptas y la diferenciación y migración luminal sirven para remplazar las células de la superficie, que se pierden por senescencia y abrasión superficial. Este recambio del epitelio superficial del colon es un proceso que tarda entre 3 y 8 días. La rápida renovación del epitelio 
proporciona a este tejido una gran capacidad de reparación, pero también como contrapunto convierte al intestino en un órgano particularmente vulnerable a factores que interfieren en la replicación celular, como la radiación y la quimioterapia antineoplásica. Este último detalle contribuye a aumentar las probabilidades de que suceda una mutación o un error que desencadene la aparición de una célula transformada con capacidad proliferativa que origine una neoplasia. Aunque esto es así en teoría, hay muchos otros factores que intervienen en los acontecimientos que desencadenan o contribuyen a la transformación de una célula normal a una tumoral, entre ellos la predisposición genética. Un ejemplo claro para ver las diferencias es que el intestino delgado también tiene una alta velocidad de recambio y la incidencia de cáncer en él es muy pequeña ${ }^{160}$.

La secuencia de acontecimientos que siguen la mayoría de los tumores malignos puede dividirse en cuatro fases: 1) cambio maligno en una célula diana, denominado transformación; 2) crecimiento de las células transformadas; 3) invasión local, y 4) metástasis a distancia.

Las mutaciones que tiene lugar habitualmente en el cáncer afectan a la regulación del ciclo celular, a la diferenciación celular, la apoptosis y las interacciones célula-célula y célula-matriz y se asocian con la expresión de genes alterados. Neoplasias diferentes tienen diferentes combinaciones de alteraciones genéticas y esto puede ser explotado en el laboratorio para obtener información de diagnóstico $\mathrm{o}$ pronóstico. Algunas alteraciones genéticas son necesarias para el desarrollo de tipos específicos de tumores $\mathrm{y}$, por tanto, son indicadores objetivos de dichas neoplasias específicas. Otras alteraciones genéticas, tales como mutaciones en el gen p53 que producen la pérdida de la función normal de la proteína en el control del ciclo celular, parecen ser un factor común a muchos tumores malignos ${ }^{161}$.

Típicamente la biología molecular del cáncer y en concreto la del cáncer colorrectal cambia a medida que una célula normal se transforma en tumoral.

Los cambios que acontecen se pueden clasificar en: 
- Cambios Epigenéticos, como la hipermetilación (metilaciones en las islas ricas en $\mathrm{CpG}$ de los promotores) y la inestabilidad en los microsatélites (MSI).

- Mutaciones o alteraciones en los genes supresores de tumores (como p53, APC/b-catenina y BRCA-1/2), en protooncogenes (como K-RAS), o en la telomerasa (que retrasa la senescencia celular).

- Pérdida de la adhesión celular, por variaciones o mutaciones en proteínas como la E-Cadherina, Cateninas (a, b y g) y CD44.

- Expresión o aumento de expresión de quinasas de tirosina, como el receptor del factor de crecimiento epidérmico (EGFR), HER2/neu, el factor de crecimiento derivado de plaquetas (PDGF), o c-met (un receptor del factor de crecimiento de hepatocitos).

- Angiogénesis, por la expresión de moléculas como el VEGF y el factor de crecimiento básico de fibroblastos (bFGF).

Además en las células tumorales se produce un cambio en el metabolismo celular, ya que las células adquieren una mayor tasa de proliferación aumentando sus consumos energéticos. Aumenta el consumo de glucosa y la liberación de lactato y $\mathrm{CO}_{2}{ }^{162}$ y aumenta la expresión de enzimas metabólicas como por ejemplo la Hexoquinasa $2^{163}$.

Con el aumento de la tasa metabólica se produce un aumento en la cantidad de ROS. Este aumento en la producción de ROS representa una paradoja para las células tumorales. Por un lado parece mantenerse bajo control por las propias células tumorales, ya que un aumento moderado en la cantidad de ROS promueve la proliferación celular y la diferenciación, sin embargo un exceso de ROS debería causar daño celular (sobre los lípidos, las proteínas y el $A D N)^{164}$. El daño oxidativo juega un papel muy importante y está presente en la patogénesis del cáncer colorrectal así como en muchos otros tipos de cáncer.

Para controlar el estrés oxidativo que se genera con el aumento de los ROS, las células tumorales comienzan a sobre-expresar enzimas antioxidantes tales como la superóxido dismutasa $(S O D)^{165}$. De esta manera sucede lo que se 
conoce con el nombre de "adaptación de la célula tumoral". Es un proceso por el cuál ante un ambiente más oxidante, como consecuencia de una mayor actividad metabólica celular, existe una compensación parcial de la situación, por la inducción de antioxidantes ${ }^{166}$.

A pesar de este sistema compensatorio, se producen una elevada cantidad de lípidos peroxidados, incrementándose incluso a medida que avanzan los estadios tumorales ${ }^{167,168}$. Los niveles de estos lípidos peroxidados se ven modificados y son medibles tanto en el tejido tumoral como en suero ${ }^{169}$. La medida de estos lípidos peroxidados en suero, se ha propuesto como marcador temprano para ayudar al diagnóstico precoz del cáncer colorrectal ${ }^{170}$.

\subsubsection{Curso temporal y características del adenocarcinoma colorrectal}

El adenocarcinoma de colorrectal es un tumor maligno que suelen provenir de pólipos y que a pesar de producir síntomas relativamente pronto en los individuos afectados, tiene una distribución mundial con tasas de mortalidad muy altas principalmente en muchos países desarrollados (como EEUU, Australia, Nueva Zelanda y países de Europa Oriental). La incidencia máxima se encuentra entre los 60 y los 79 años. No existen diferencias significativas en cuanto al sexo, existiendo una ratio mundial hombres:mujeres de 1,2:1. Lo que sí tiene mucha importancia son los factores ambientales y particularmente los patrones dietéticos, dadas las notables diferencias geográficas que existen. Un caso que ejemplifica esto es lo sucedido en las familias japonesas y polacas que emigraron a Estados Unidos y tras adoptar los patrones dietéticos estadounidenses, al cabo de 20 años habían adquirido la tasa de prevalencia de dicho país a pesar de provenir de países con tasas bajas de dicho tipo de cáncer.

En cuanto a los factores dietéticos, aunque sigue habiendo controversia, se cree que influyen sobre la incidencia: una ingesta de calorías superior a los requerimientos, un contenido bajo de fibras vegetales, alto contenido de hidratos de carbono refinados, elevado consumo de carnes rojas y una disminución de la ingesta de micronutrientes protectores como son 
determinadas vitaminas, son todos factores que correlacionan con el padecimiento de este tipo de cáncer.

Los cánceres colorrectales tienen un crecimiento relativamente lento y permanecen asintomáticos durante años y esto tiene relación con la velocidad de crecimiento de las células del tumor y el periodo de latencia. La velocidad de crecimiento del tumor está pautada por el tiempo de duplicación de las células (teniendo en cuenta que el tiempo que se tarda en realizar un ciclo celular completo es igual en las células tumorales que en las normales) y la ratio entre las células que se integran en la masa replicante y aquellas que se pierden por muerte o diseminación. El periodo de latencia es el que transcurre hasta que el tumor es clínicamente detectable. Un tumor no es detectable hasta que tiene un tamaño mínimo de $1 \mathrm{~cm}$, pero siempre y cuando se realice una prueba que lo ponga de manifiesto. En el caso del cáncer colorrectal el periodo es mayor dependiendo del lugar exacto de asentamiento, ya que sólo en algunos casos se desarrollan signos que sean interpretados como indicio de sospecha de la patología (en los tumores de ciego y de colon derecho se observa anemia ferropénica y en los de colon izquierdo cursan con sangre oculta, melenas, estreñimiento). Sin embargo los cánceres de sigma y de recto dan menos signos clínicos y son más infiltrantes de modo que en el momento del diagnóstico presentan peores pronósticos.

Los tumores colorrectales se extienden por invasión directa de estructuras adyacentes (serosa del peritoneo) y por metástasis, principalmente a través de los ganglios linfáticos regionales y del hígado.

El mejor indicador pronóstico es la extensión del adenocarcinoma colorrectal en el momento del diagnóstico. Es lo que se llama "estadio" del tumor. Aster y Coller describieron en los años 60' un sistema de estadificación que ha sido muy usado gracias también a las modificaciones añadidas por Dukes. Sin embargo hoy en día el sistema de clasificación más usado tanto en América como en Europa es el TMN (tumor-nodes-metastasis o tumor-gangliosmetástasis) (Tabla 1). Los criterios para la estadificación anatomopatológica se muestran en la Figura 8. De esta manera sólo se puede decir el estadio tras la 
exploración quirúrgica y el examen anatómico del tejido. Por esta razón el reto para el futuro consiste en descubrir esas neoplasias los suficientemente temprano como para que la resección sea una solución curativa, preferiblemente cuando son aún pólipos adenomatosos.

\section{Clasificación TNM}

\section{Tumor Primario (T)}

TX. No puede evaluarse el tumor primario

T0. No hay indicación de tumor primario

Tis. Carcinoma in situ: intraepitelial o invasión de la lámina propia

T1. El tumor invade la submucosa

T2. El tumor invade la muscularis propria

T3. El tumor invade la subserosa o los tejidos pericólicos o perirrectales no peritonealizados a través de la muscularis propria

T4. El tumor invade directamente otros órganos o estructuras o perfora el peritoneo visceral o ambos

\section{Ganglios linfáticos regionales $(N)$}

NX. No pueden evaluarse los ganglios regionales

No. No hay metástasis de los ganglios linfáticos regionales

N1. Metástasis en uno a tres ganglios linfáticos regionales

N2. Metástasis en cuatro o más ganglios linfáticos regionales

\section{Metástasis distante (M)}

MX. No puede evaluarse la metástasis distante

M0. No hay metástasis distante

M1. Metástasis distante

Tabla 1. Clasificación TNM de tumores de colon.

\begin{tabular}{|l|}
\hline $\begin{array}{c}\text { Etapificación cáncer } \\
\text { colorectal }\end{array}$ \\
\hline Estadio 0 \\
Tis, N0, M0 \\
Estadio I \\
T1, N0, M0 \\
T2, NO, M0 \\
Estadio IIA \\
T3, NO, M0 \\
Estadio IIB \\
T4, NO, M0 \\
Estadio IIIA \\
T1, N1, M0 \\
T2, N1, M0 \\
Estadio IIIB \\
T3, N1, M0 \\
T4, N1, M0 \\
Estadio IIIC \\
Cualquier T, N2, M0 \\
Estadio IV \\
Cualquier T, cualquier N, M1 \\
\hline
\end{tabular}

Fig.8. Estadiaje bajo criterios de anatomía patológica, aceptado internacionalmente como por la American Joint Committee on Cancer (AJCC) y la Union for International Cancer Control (UICC).

Hoy en día se trabaja intensamente en reducir en lo posible el tiempo de diagnóstico. Los esfuerzos se encaminan a la exploración rutinaria de factores genéticos (mutaciones en genes como el BRCA-1 y -2), al cribado poblacional 
usando pruebas como la sangre oculta en heces y la colonoscopia para población que está en edad de riesgo (a partir de los 50). Sin embargo la demanda y el deseo tanto de los clínicos como de los propios pacientes es el descubrimiento de marcadores detectables de manera temprana y mediante técnicas no invasivas (marcadores que dejen su huella en sangre periférica).

\subsubsection{ApoD y el adenocarcinoma colorrectal}

Se ha descrito que $A p o D$ es unos de esos genes que sufre modificaciones epigenéticas por metilaciones en su promotor en los tejidos de pacientes y en algunas líneas celulares provenientes de cáncer colorrectal ${ }^{171}$. Se piensa que es debido a este mecanismo de represión por lo que se observa una disminución de la expresión de $A p o D$ cuando el estadio tumoral está más avanzado y cuando existen metástasis en los ganglios adyacentes ${ }^{171}$.

Una de las últimas averiguaciones acerca de $A p o D^{172}$ es que se ha comprobado que su expresión está controlada por p73, principalmente, y también por p63 (ambas proteínas de la familia de p53). p73 es capaz de reducir la proliferación celular en varios tipos celulares (osteosarcomas y neuroblastomas). Concretamente en el modelo neuronal la adición de ApoD promueve su diferenciación. Por todo esto, los autores concluyen que la inducción de la expresión de ApoD por acción de p73 inhibe la proliferación de las células cancerígenas a través de una activación de parada del ciclo celular y/o una entrada en las vías de diferenciación celular. Saber si esta forma de regulación también ocurre en los adenocarcinomas de colon y otros tumores sería de mucho interés.

Cómo he comentado anteriormente, ApoD se ha propuesto como marcador de buen pronóstico en una gran variedad de cánceres, incluido el colorrectal ${ }^{171}$. Sin embargo aún queda por saber qué mecanismos regulan su expresión a lo largo de la evolución del tumor. Hemos comentado que la producción de ROS aumenta con la progresión del tumor y sabemos que la expresión de ApoD aumenta en situaciones de estrés oxidativo tanto durante el envejecimiento normal como en el envejecimiento patológico del sistema nervioso. Si 
queremos generalizar la conclusión de que $A p o D$ ejerce acciones protectoras, toca resolver la paradoja que ocurre en las patologías cancerosas en las que ApoD baja su expresión a medida que avanza el estadio del tumor. Para ello debemos comprender tanto las vías que regulan la expresión de ApoD como las que son reguladas por ella.

\subsection{Cascadas de señalización relacionadas con las respuestas al estrés oxidativo: Las MAP quinasas.}

Como he comentado anteriormente, un nivel basal de estrés oxidativo se produce de modo inevitable como consecuencia del metabolismo celular, y es en situaciones patológicas o durante el envejecimiento cuando los sistemas de protección celular dejan de ser muy efectivos y no consiguen prevenir los efectos negativos ${ }^{173}$. Los sistemas antioxidantes celulares fallan por el deterioro en la función de enzimas antioxidantes y por la disfunción mitocondrial que acompaña al envejecimiento ${ }^{174}$.

Por otro lado, los ROS pueden actuar también como moléculas señalizadoras, activando directamente cascadas de señalización celular que también pueden ser disparadas por factores de crecimiento, citoquinas o ciertas hormonas ${ }^{175}$. Estas redes de señalización activadas por ROS y otras señales son vías de respuesta global al estrés. No son específicas ni de un determinado tipo de estrés ni de un tipo celular. Dentro de las rutas de respuesta global al estrés se encuentran aquellas en las que intervienen las proteínas quinasa activadas por mitógenos (MAPK) (Figura 9). Estas incluyen la vía de la proteína p38, la de la quinasa $\mathrm{NH} 2$-terminal de c-Jun (JNK) y la de las quinasas reguladas por señales extracelulares (ERKs) que están estrechamente relacionadas con la proliferación celular y la apoptosis. El equilibrio entre ellas determina el destino de la célula ${ }^{176}$. Las cascadas de señalización reaccionan a estímulos mitogénicos y hacen que la célula se divida o que el tejido prolifere, pero también son activadas por otro tipo de estímulos que hacen que la célula entre en el programa de muerte programada, apoptosis ${ }^{177}$. 


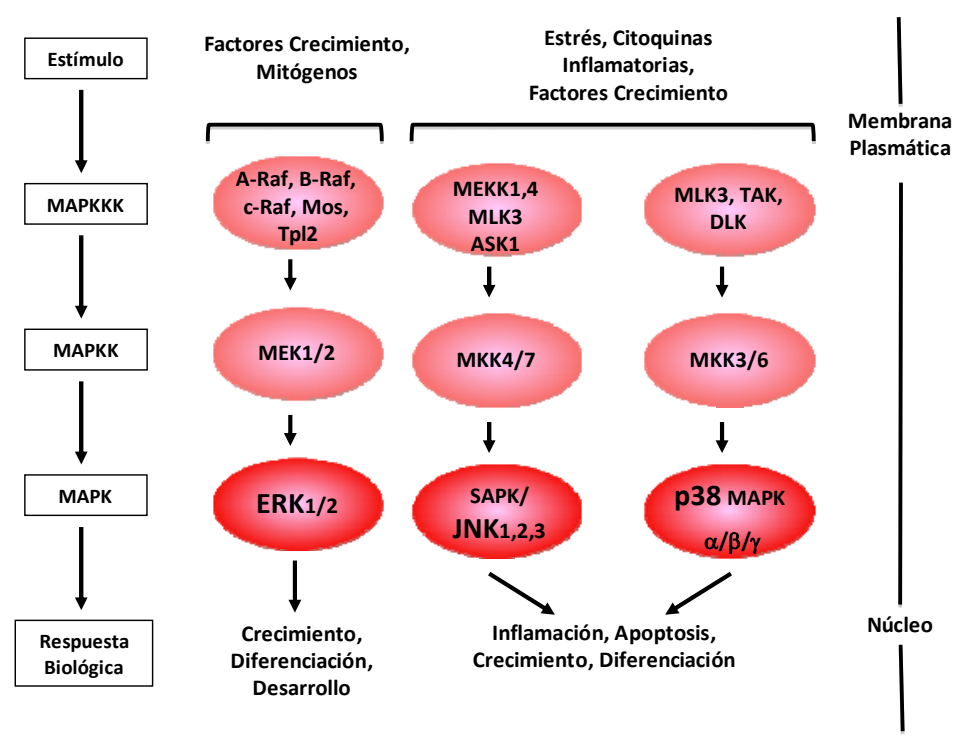

Fig.8. MAPK o MAP quinasas. Vías de señalización clásicas de las MAP kinasas, activadas por varios estímulos como los factores de crecimiento, las citoquinas o el estrés. Estas vías desencadenan respuetas biológias diversas en concordancia al estímulo que las activó.

La señalización por MAPK puede producir distintos efectos: puede proteger o puede incrementar la sensibilidad a los procesos apoptóticos. El resultado final depende del tipo de célula, de los estímulos y del patrón temporal de activación de las distintas MAPK. Estas cascadas de señalización ejercen importantes funciones reguladoras para una gran variedad de moléculas que van desde factores de transcripción, a proteínas del ciclo celular y a otras quinasas. Además pueden modular la proliferación celular, la migración, la parada del ciclo celular, la diferenciación, la senescencia y la apoptosis.

ERK1 y ERK 2 son activadas en respuestas de crecimiento y clásicamente se les ha asociado con la proliferación y la supervivencia celular. Sin embargo, p38 y JNK se han considerado más sensibles a señales de estrés y por lo tanto, se involucra en procesos de apoptosis celular.

La regulación de los procesos apoptóticos por JNK se ejerce gracias a los efectos que tiene sobre la expresión génica. Se conocen bastantes factores de transcripción activados por JNK, como el clásico c-Jun y otros como ATF2, Elk1, p53, c-Myc ${ }^{178,179}$, así como Bcl-2 ${ }^{180}$ o moléculas del ciclo celular ${ }^{181}$. 
La apoptosis es uno de los puntos clave en la investigación contra el cáncer, ya que el crecimiento de un tumor depende del equilibrio entre la proliferación y la muerte celular. Los defectos en el proceso de apoptosis participan en la tumorogénesis, y además suelen ser la causa de fallo de la quimioterapia ${ }^{182}$. Las células cancerígenas adquieren la capacidad de evadir las rutas apoptóticas, tanto la vía extrínseca, activada por señales extracelulares, como la intrínseca, activada por alteraciones mitocondriales ${ }^{183}$. Una de las mutaciones que suceden con más frecuencia en las células cancerígenas suceden en el gen de p53 (regulado por la vía de JNK) cuya pérdida de función desactiva la apoptosis y acelera el desarrollo tumoral ${ }^{184}$.

\subsubsection{Vías de señalización que controlan o son controladas por ApoD}

En el apartado dedicado a las enfermedades cardiovasculares asociadas al envejecimiento vimos como la sobre-expresión o adición de $A p o D$ inhibe la respuesta de las células de músculo liso vascular a señales proliferativas y que esta acción es dependiente de la señalización llevada a cabo por la quinasa $\mathrm{ERK}^{84,85}$.Esta acción de ApoD mediada por la vía de ERK es especialmente relevante en el control de la proliferación en la placa de ateroma. ApoD ejerce un bloqueo indirecto de la traslocación de la forma activa de ERK (fosfo-ERK) al núcleo, donde ésta ejerce su acción ${ }^{84}$. Curiosamente, este mismo bloqueo de la translocación de ERK al núcleo lo llevan a cabo los antagonistas del $\mathrm{Ca2+}$, utilizados como medicamentos en el tratamiento de la hipertensión.

Pero ¿quién pone en marcha la expresión de ApoD en las múltiples situaciones en las que se sabe que se sobre-expresa?

Por un lado, hemos visto que los organismos que carecen de ApoD muestran deficiencias que les hacen más vulnerables y que los tumores que tienen ApoD disminuida tienen un mal pronóstico. Por otro, paso a describir como en organismos o modelos celulares que expresan ApoD, la expresión de este gen responde cambiando de nivel ante determinados estímulos que provocan estrés o daño. 
La expresión de ApoD aumenta en varios tipos celulares, así como en el organismo completo, en respuesta a tratamientos con $\mathrm{PQ}^{46}$ con radiación ultravioleta ${ }^{109}$ con $\mathrm{H}_{2} \mathrm{O}_{2}{ }^{109}$, con estímulos inflamatorios (LPS) ${ }^{109}$ por deprivación de suero ${ }^{109}$, tras una situación de daño en nervios periféricos ${ }^{49} \circ$ ante infecciones víricas ${ }^{50}$. También sube su expresión en muchas líneas celulares cuando el cultivo llega a la confluencia y las células dejan de dividirse ${ }^{109}$. En todos los casos la sobre-expresión o el tratamiento con ApoD exógena está relacionada con una mejor resistencia al estrés, una mejora de la viabilidad celular y una reducción de la proliferación.

Algunos de los elementos reguladores en el promotor de ApoD han sido analizados con detalle ${ }^{22,109}$, habiéndose encontrado regiones concretas que determinan la expresión de ApoD inducida por "growth arrest" o por señales proinflamatorias.

Dado que las vías de las MAPK, y concretamente las vía de JNK se pone en marcha en respuesta a muchos de los estímulos que inducen la expresión de ApoD, uno de los objetivos de este trabajo ha consistido en comprobar si JNK regula la expresión de ApoD. Un dato que apoya esta hipótesis es que la expresión de NLaz, uno de los homólogos de ApoD en Drosophila, está controlada por la vía de $\mathrm{JNK}^{43}$ en respuestas a estímulos de deprivación nutricional o estrés oxidativo.

Todos los datos recopilados en esta introducción anticipan los objetivos que nos hemos planteado resolver en este trabajo. Es precisamente el hecho de que la expresión de ApoD se encuentre aumentada en situaciones patológicas y en el envejecimiento, junto con el conocimiento de que a estas situaciones se llega por un aumento de los niveles de ROS, lo que motiva a relacionar a ApoD con el estrés oxidativo y adjudicarle un papel de protector.

Teniendo en cuenta todos los datos que se conocen a día de hoy sobre ApoD, podemos hacernos una idea de la relevancia y pertinencia que tiene estudiar a fondo el mecanismo de acción de esta proteína tanto en un contexto de 
normalidad, como en uno patológico. Conocer cuál es la función de ApoD, así como su mecanismo de acción y su regulación, nos ayudaría a desarrollar, bien un tipo de prueba diagnóstica, o bien un tipo de estimulación/administración de ApoD como mecanismo de ayuda para ciertas patologías neurodegenerativas o ciertos tipos de cáncer.

Para conseguir este ambicioso objetivo general se necesita aún mucho trabajo, pero con esta tesis se pretende dar luz a la parte relativa al comportamiento celular en el que interviene ApoD ante el estrés oxidativo en dos modelos muy diferentes, uno esencialmente proliferativo (el cáncer de colon) y otro esencialmente postmitótico (el sistema nervioso).

\subsection{Bibliografía}

1. Oliveira BF, Nogueira-Machado JA, Chaves MM. The role of oxidative stress in the aging process. ScientificWorldJournal. 2010;10:1121-1128.

2. Gerschman R, Gilbert DL, Nye SW, Dwyer P, Fenn WO. Oxygen poisoning and x-irradiation: a mechanism in common. Science. 1954;119(3097):623-626.

3. Harman D. Aging: a theory based on free radical and radiation chemistry. J Gerontol. 1956;11(3):298-300.

4. Harman D. Mutation, cancer, and ageing. Lancet. 1961;1(7170):200-201.

5. Sies $\mathrm{H}$, Cadenas $\mathrm{E}$. Oxidative stress: damage to intact cells and organs. Philos Trans R Soc Lond B Biol Sci. 1985;311(1152):617-631.

6. Floyd RA, Towner RA, He T, Hensley K, Maples KR. Translational research involving oxidative stress and diseases of aging. Free Radic Biol Med.51(5):931-941.

7. Valko M, Leibfritz D, Moncol J, Cronin MT, Mazur M, Telser J. Free radicals and antioxidants in normal physiological functions and human disease. Int J Biochem Cell Biol. 2007;39(1):44-84.

8. Harman D. Secondary amyloidosis and antioxidants. Lancet. 1980;2(8194):593.

9. Ingold KU, Bowry VW, Stocker R, Walling C. Autoxidation of lipids and antioxidation by alpha-tocopherol and ubiquinol in homogeneous solution and in aqueous dispersions of lipids: unrecognized consequences of lipid particle size as exemplified by oxidation of human low density lipoprotein. Proc Natl Acad Sci U S A. 1993;90(1):45-49. 
10. Gutteridge JM, Halliwell B. Antioxidants: Molecules, medicines, and myths. Biochem Biophys Res Commun.393(4):561-564.

11. Skorupa DA, Dervisefendic A, Zwiener J, Pletcher SD. Dietary composition specifies consumption, obesity, and lifespan in Drosophila melanogaster. Aging Cell. 2008;7(4):478-490.

12. Fontana L, Partridge L, Longo VD. Extending healthy life span--from yeast to humans. Science. 2010;328(5976):321-326.

13. Tatar M, Kopelman A, Epstein D, Tu MP, Yin CM, Garofalo RS. A mutant Drosophila insulin receptor homolog that extends life-span and impairs neuroendocrine function. Science. 2001;292(5514):107-110.

14. Clancy DJ, Gems D, Harshman LG, Oldham S, Stocker H, Hafen E, Leevers SJ, Partridge L. Extension of life-span by loss of CHICO, a Drosophila insulin receptor substrate protein. Science. 2001;292(5514):104-106.

15. Berryman DE, Christiansen JS, Johannsson G, Thorner MO, Kopchick JJ. Role of the GH/IGF-1 axis in lifespan and healthspan: lessons from animal models. Growth Horm IGF Res. 2008;18(6):455-471.

16. Dillin A, Hsu AL, Arantes-Oliveira N, Lehrer-Graiwer J, Hsin H, Fraser AG, Kamath RS, Ahringer J, Kenyon C. Rates of behavior and aging specified by mitochondrial function during development. Science. 2002;298(5602):2398-2401.

17. Loerch PM, Lu T, Dakin KA, Vann JM, Isaacs A, Geula C, Wang J, Pan Y, Gabuzda DH, Li C, Prolla TA, Yankner BA. Evolution of the Aging Brain Transcriptome and Synaptic Regulation. PLOS ONE. 2008;3(10):e3329.

18. de Magalhaes JP, Curado J, Church GM. Meta-analysis of age-related gene expression profiles identifies common signatures of aging. Bioinformatics. 2009;25(7):875-881.

19. McConathy WJ, Alaupovic P. Isolation and partial characterization of apolipoprotein D: a new protein moiety of the human plasma lipoprotein system. FEBS Lett. 1973;37(2):178-182.

20. Sanchez D, Ganfornina MD, Gutiérrez G, Marín A. Exon-intron structure and evolution of the lipocalin gene family. Molecular Biology and Evolution. 2003;20(5):775-783.

21. Drayna D, Fielding C, McLean J, Baer B, Castro G, Chen E, Comstock L, Henzel W, Kohr W, Rhee $L$, et al. Cloning and expression of human apolipoprotein D cDNA. J Biol Chem. 1986;261(35):16535-16539.

22. Do Carmo S, Sc)guin D, Milne R, Rassart E. Modulation of Apolipoprotein D and Apolipoprotein E mRNA Expression by Growth Arrest and Identification of Key Elements in the Promoter. Journal of Biological Chemistry. 2002;277(7):5514-5523. 
23. Rassart E, Bedirian A, Do Carmo S, Guinard O, Sirois J, Terrisse L, Milne R. Apolipoprotein D. Biochimica et Biophysica Acta (BBA) - Protein Structure and Molecular Enzymology. 2000;1482(1-2):185-198.

24. Hu CY, Ong WY, Sundaram RK, Chan C, Patel SC. Immunocytochemical localization of apolipoprotein $D$ in oligodendrocyte precursor-like cells, perivascular cells, and pericytes in the human cerebral cortex. J Neurocytol. 2001;30(3):209-218.

25. del Valle E, Navarro A, Astudillo A, Tolivia J. Apolipoprotein D expression in human brain reactive astrocytes. J Histochem Cytochem. 2003;51(10):1285-1290.

26. Eichinger A, Nasreen A, Kim HJ, Skerra A. Structural insight into the dual ligand specificity and mode of high density lipoprotein association of apolipoprotein D. J Biol Chem. 2007;282(42):31068-31075.

27. Flower DR. The lipocalin protein family: structure and function. Biochem J. 1996;318 ( Pt 1):1-14.

28. Flower DR. Beyond the superfamily: the lipocalin receptors. Biochim Biophys Acta. 2000;1482(1-2):327-336.

29. Patel RC, Lange D, McConathy WJ, Patel YC, Patel SC. Probing the structure of the ligand binding cavity of lipocalins by fluorescence spectroscopy. Protein Eng. 1997;10(6):621-625.

30. Breustedt DA, Korndorfer IP, Redl B, Skerra A. The 1.8-A crystal structure of human tear lipocalin reveals an extended branched cavity with capacity for multiple ligands. J Biol Chem. 2005;280(1):484-493.

31. Morais Cabral JH, Atkins GL, Sanchez LM, Lopez-Boado YS, Lopez-Otin C, Sawyer L. Arachidonic acid binds to apolipoprotein D: implications for the protein's function. FEBS Lett. 1995;366(1):53-56.

32. Vogt $M$, Skerra A. Bacterially produced apolipoprotein $D$ binds progesterone and arachidonic acid, but not bilirubin or $\mathrm{E}-3 \mathrm{M} 2 \mathrm{H}$. J Mol Recognit. 2001;14(1):79-86.

33. Zeng C, Spielman Al, Vowels BR, Leyden JJ, Biemann K, Preti G. A human axillary odorant is carried by apolipoprotein D. Proc Natl Acad Sci U S A. 1996;93(13):6626-6630.

34. Akerstrom B, Maghzal GJ, Winterbourn CC, Kettle AJ. The lipocalin alpha1-microglobulin has radical scavenging activity. $\mathrm{J}$ Biol Chem. 2007;282(43):31493-31503.

35. Steyrer E, Kostner GM. Activation of lecithin-cholesterol acyltransferase by apolipoprotein $\mathrm{D}$ : comparison of proteoliposomes containing apolipoprotein D, A-I or C-I. Biochim Biophys Acta. 1988;958(3):484-491.

36. Ganfornina MD, Gutierrez G, Bastiani M, Sanchez D. A phylogenetic analysis of the lipocalin protein family. Mol Biol Evol. 2000;17(1):114126. 
37. Ganfornina MD, Sanchez D, Bastiani MJ. Lazarillo, a new GPI-linked surface lipocalin, is restricted to a subset of neurons in the grasshopper embryo. Development. 1995;121:123-134.

38. Sanchez D, Ortega-Cubero S, Åkerström B, Herrera M, Bastiani MJ, Ganfornina MD. Molecular interactions of the neuronal GPI-anchored lipocalin Lazarillo. Journal of Molecular Recognition. 2008;21(5):313-323.

39. Sanchez D, Ganfornina MD, Torres-Schumann S, Speese SD, Lora JM, Bastiani MJ. Characterization of two novel lipocalins expressed in the Drosophila embryonic nervous system. Int. J. Dev. Biol. 2000;44:349360.

40. Sanchez D, Lopez-Arias B, Torroja L, Canal I, Wang X, Bastiani MJ, Ganfornina MD. Loss of glial lazarillo, a homolog of apolipoprotein D, reduces lifespan and stress resistance in Drosophila. Curr Biol. 2006;16(7):680-686.

41. Walker DW, Muffat J, Rundel C, Benzer S. Overexpression of a Drosophila Homolog of Apolipoprotein D Leads to Increased Stress Resistance and Extended Lifespan. Current Biology. 2006;16(7):674679.

42. Muffat J, Walker DW, Benzer S. Human ApoD, an apolipoprotein upregulated in neurodegenerative diseases, extends lifespan and increases stress resistance in Drosophila. Proc Natl Acad Sci $U S A$. 2008;105(19):7088-7093.

43. Hull-Thompson J, Muffat J, Sanchez D, Walker DW, Benzer S, Ganfornina MD, Jasper $\mathrm{H}$. Control of metabolic homeostasis by stress signaling is mediated by the lipocalin NLaz. PLoS Genet. 2009;5(4):e1000460.

44. Charron JB, Ouellet F, Houde M, Sarhan F. The plant Apolipoprotein D ortholog protects Arabidopsis against oxidative stress. BMC Plant Biol. 2008;8:86.

45. Zhang $\mathrm{Y}$, Cong $\mathrm{Y}$, Wang $\mathrm{S}$, Zhang $\mathrm{S}$. Antioxidant activities of recombinant amphioxus (Branchiostoma belcheri) apolipoprotein D. Molecular Biology Reports. 2010:1-5.

46. Ganfornina MD, Do Carmo S, Lora JM, Torres-Schumann S, Vogel M, Allhorn M, González C, Bastiani MJ, Rassart E, Sanchez D. Apolipoprotein $\mathrm{D}$ is involved in the mechanisms regulating protection from oxidative stress. Aging Cell. 2008;7(4):506-515.

47. Rajput PS, Billova S, Patel SC, Kharmate G, Somvanshi RK, Kumar U. Expression of somatostatin and somatostatin receptor subtypes in Apolipoprotein D (ApoD) knockout mouse brain: An immunohistochemical analysis. J Chem Neuroanat. 2009;38(1):20-33.

48. Boer S, Sanchez D, Reinieren I, van den Boom T, Udawela M, Scarr E, Ganfornina MD, Dean B. Decreased kainate receptors in the hippocampus of apolipoprotein D knockout mice. Progress in NeuroPsychopharmacology and Biological Psychiatry. 2010;34(2):271-278. 
49. Ganfornina MD, Do Carmo S, Martínez E, Tolivia J, Navarro A, Rassart E, Sanchez D. ApoD, a glia-derived apolipoprotein, is required for peripheral nerve functional integrity and a timely response to injury. Glia. 2010;58(11):1320-1334.

50. Do Carmo S, Jacomy H, Talbot PJ, Rassart E. Neuroprotective effect of apolipoprotein $D$ against human coronavirus OC43-induced encephalitis in mice. J Neurosci. 2008;28(41):10330-10338.

51. Terrisse L, Poirier J, Bertrand P, Merched A, Visvikis S, Siest G, Milne R, Rassart E. Increased levels of apolipoprotein D in cerebrospinal fluid and hippocampus of Alzheimer's patients. J Neurochem. 1998;71(4):16431650.

52. Glockner F, Ohm TG. Hippocampal apolipoprotein D level depends on Braak stage and APOE genotype. Neuroscience. 2003;122(1):103-110.

53. Kalman J, McConathy W, Araoz C, Kasa P, Lacko AG. Apolipoprotein D in the aging brain and in Alzheimer's dementia. Neurol Res. 2000;22(4):330-336.

54. Thomas EA, Laws SM, Sutcliffe JG, Harper C, Dean B, McClean C, Masters C, Lautenschlager N, Gandy SE, Martins RN. Apolipoprotein D levels are elevated in prefrontal cortex of subjects with Alzheimer's disease: no relation to apolipoprotein $\mathrm{E}$ expression or genotype. Biol Psychiatry. 2003;54(2):136-141.

55. Belloir B, Kovari E, Surini-Demiri M, Savioz A. Altered apolipoprotein D expression in the brain of patients with Alzheimer disease. J Neurosci Res. 2001;64(1):61-69.

56. Navarro A, Del Valle E, Astudillo A, Gonzalez del Rey C, Tolivia J. Immunohistochemical study of distribution of apolipoproteins $E$ and $D$ in human cerebral beta amyloid deposits. Exp Neurol. 2003;184(2):697704.

57. Helisalmi S, Hiltunen M, Vepsalainen S, livonen S, Corder EH, Lehtovirta $M$, Mannermaa A, Koivisto AM, Soininen $H$. Genetic variation in apolipoprotein D and Alzheimer's disease. J Neurol. 2004;251(8):951957.

58. Desai PP, Hendrie HC, Evans RM, Murrell JR, DeKosky ST, Kamboh MI. Genetic variation in apolipoprotein $D$ affects the risk of Alzheimer disease in African-Americans. Am J Med Genet B Neuropsychiatr Genet. 2003;116B(1):98-101.

59. Chen Y, Jia L, Wei C, Wang F, Lv H, Jia J. Association between polymorphisms in the apolipoprotein $D$ gene and sporadic Alzheimer's disease. Brain Res. 2008;1233:196-202.

60. Wakasaya $\mathrm{Y}$, Kawarabayashi T, Watanabe M, Yamamoto-Watanabe $\mathrm{Y}$, Takamura A, Kurata T, Murakami T, Abe K, Yamada K, Wakabayashi K, Sasaki A, Westaway D, Hyslop PS, Matsubara E, Shoji M. Factors responsible for neurofibrillary tangles and neuronal cell losses in tauopathy. J Neurosci Res.89(4):576-584. 
61. Thomas EA, Sautkulis LN, Criado JR, Games D, Sutcliffe JG. Apolipoprotein D mRNA expression is elevated in PDAPP transgenic mice. J Neurochem. 2001;79(5):1059-1064.

62. Terrisse L, Seguin D, Bertrand P, Poirier J, Milne R, Rassart E. Modulation of apolipoprotein $\mathrm{D}$ and apolipoprotein $\mathrm{E}$ expression in rat hippocampus after entorhinal cortex lesion. Brain Res Mol Brain Res. 1999;70(1):26-35.

63. Ordonez C, Navarro A, Perez C, Astudillo A, Martinez E, Tolivia J. Apolipoprotein $D$ expression in substantia nigra of Parkinson disease. Histol Histopathol. 2006;21(4):361-366.

64. Uranga RM, Bruce-Keller AJ, Morrison CD, Fernandez-Kim SO, Ebenezer PJ, Zhang L, Dasuri K, Keller JN. Intersection between metabolic dysfunction, high fat diet consumption, and brain aging. $J$ Neurochem. 2010;114(2):344-361.

65. Rickhag M, Deierborg T, Patel S, Ruscher K, Wieloch T. Apolipoprotein $D$ is elevated in oligodendrocytes in the peri-infarct region after experimental stroke: influence of enriched environment. J Cereb Blood Flow Metab. 2008;28(3):551-562.

66. Suresh S, Yan Z, Patel RC, Patel YC, Patel SC. Cellular cholesterol storage in the Niemann-Pick disease type $\mathrm{C}$ mouse is associated with increased expression and defective processing of apolipoprotein D. J Neurochem. 1998;70(1):242-251.

67. Dandoy-Dron F, Guillo F, Benboudjema L, Deslys JP, Lasmezas C, Dormont D, Tovey MG, Dron M. Gene expression in scrapie. Cloning of a new scrapie-responsive gene and the identification of increased levels of seven other mRNA transcripts. J Biol Chem. 1998;273(13):7691-7697.

68. Sutcliffe JG, Thomas EA. The neurobiology of apolipoproteins in psychiatric disorders. Mol Neurobiol. 2002;26(2-3):369-388.

69. Thomas EA, Yao JK. Clozapine specifically alters the arachidonic acid pathway in mice lacking apolipoprotein D. Schizophr Res. 2007;89(13):147-153.

70. Thomas EA, Dean B, Pavey G, Sutcliffe JG. Increased CNS levels of apolipoprotein $\mathrm{D}$ in schizophrenic and bipolar subjects: implications for the pathophysiology of psychiatric disorders. Proc Natl Acad Sci U S A. 2001;98(7):4066-4071.

71. Ong WY, He Y, Suresh S, Patel SC. Differential expression of apolipoprotein $\mathrm{D}$ and apolipoprotein $\mathrm{E}$ in the kainic acid-lesioned rat hippocampus. Neuroscience. 1997;79(2):359-367.

72. Thomas EA, George RC, Sutcliffe JG. Apolipoprotein D modulates arachidonic acid signaling in cultured cells: implications for psychiatric disorders. Prostaglandins, Leukotrienes and Essential Fatty Acids. 2003;69(6):421-427.

73. Kamboh MI, Albers JJ, Majumder PP, Ferrell RE. Genetic studies of human apolipoproteins. IX. Apolipoprotein D polymorphism and its 
relation to serum lipoprotein lipid levels. Am $J$ Hum Genet. 1989;45(1):147-154.

74. Desai PP, Bunker CH, Ukoli FA, Kamboh MI. Genetic variation in the apolipoprotein $D$ gene among African blacks and its significance in lipid metabolism. Atherosclerosis. 2002;163(2):329-338.

75. Vijayaraghavan S, Hitman GA, Kopelman PG. Apolipoprotein-D polymorphism: a genetic marker for obesity and hyperinsulinemia. J Clin Endocrinol Metab. 1994;79(2):568-570.

76. Baker WA, Hitman GA, Hawrami K, McCarthy MI, Riikonen A, Tuomilehto-Wolf E, Nissinen A, Tuomilehto J, Mohan V, Viswanathan M, et al. Apolipoprotein $D$ gene polymorphism: a new genetic marker for type 2 diabetic subjects in Nauru and south India. Diabet Med. 1994;11(10):947-952.

77. Hitman GA, McCarthy MI, Mohan V, Viswanathan M. The genetics of non-insulin-dependent diabetes mellitus in south India: an overview. Ann Med. 1992;24(6):491-497.

78. Wiklund O, Fager G, olofsson SO, Wilhelmsson C, Bondjers G. Serum apolipoprotein levels in relation to acute myocardial infarction and its risk factors--determination of apolipoprotein D. Atherosclerosis. 1980;37(4):631-636.

79. Wei YJ, Huang YX, Zhang XL, Li J, Huang J, Zhang $H$, Hu SS. Apolipoprotein $\mathrm{D}$ as a novel marker in human end-stage heart failure: a preliminary study. Biomarkers. 2008;13(5):535-548.

80. Perdomo G, Kim D, Zhang T, Qu S, Thomas E, Toledo F, Slusher S, Fan $Y$, Kelley $D$, Dong $H$. A role of apolipoprotein $D$ in triglyceride metabolism. J Lipid Res. 2010.

81. Jimenez-Palomares M, Cozar-Castellano I, Ganfornina MD, Sanchez D, Perdomo G. Genetic deficiency of apolipoprotein D in the mouse is associated with nonfasting hypertriglyceridemia and hyperinsulinemia. Metabolism.60(12):1767-1774.

82. Do Carmo S, Fournier D, Mounier C, Rassart E. Human apolipoprotein D overexpression in transgenic mice induces insulin resistance and alters lipid metabolism. Am J Physiol Endocrinol Metab. 2009;296(4):E802-811.

83. Ruiz M, Sanchez D, Canal I, Acebes A, Ganfornina MD. Sex-dependent modulation of longevity by two Drosophila homologues of human Apolipoprotein D, GLaz and NLaz. Experimental Gerontology. 2011;doi: DOI: 10.1016/j.exger.2011.02.014.

84. Sarjeant JM, Lawrie A, Kinnear C, Yablonsky S, Leung W, Massaeli H, Prichett W, Veinot JP, Rassart E, Rabinovitch M. Apolipoprotein D inhibits platelet-derived growth factor-BB-induced vascular smooth muscle cell proliferated by preventing translocation of phosphorylated extracellular signal regulated kinase $1 / 2$ to the nucleus. Arterioscler Thromb Vasc Biol. 2003;23(12):2172-2177. 
85. Leung WCY, Lawrie A, Demaries S, Massaeli H, Burry A, Yablonsky S, Sarjeant JM, Fera E, Rassart E, Pickering JG, Rabinovitch M. Apolipoprotein D and Platelet-Derived Growth Factor-BB Synergism Mediates Vascular Smooth Muscle Cell Migration. Circ Res. 2004;95(2):179-186.

86. Perdomo G, Dong $H$. Apolipoprotein $D$ in lipid metabolism and its functional implication in atherosclerosis and aging. Aging (Albany NY). 2009;1(1):17-27.

87. Haagensen DE, Jr., Mazoujian G, Holder WD, Jr., Kister SJ, Wells SA, $\mathrm{Jr}$. Evaluation of a breast cyst fluid protein detectable in the plasma of breast carcinoma patients. Ann Surg. 1977;185(3):279-285.

88. Balbin M, Freije JM, Fueyo A, Sanchez LM, Lopez-Otin C. Apolipoprotein $\mathrm{D}$ is the major protein component in cyst fluid from women with human breast gross cystic disease. Biochem J. 1990;271(3):803-807.

89. Simard J, Veilleux R, de Launoit $Y$, Haagensen DE, Labrie F. Stimulation of apolipoprotein $\mathrm{D}$ secretion by steroids coincides with inhibition of cell proliferation in human LNCaP prostate cancer cells. Cancer Res. 1991;51(16):4336-4341.

90. Haagensen DE, Stewart P, Dilley WG, Wells SA. Secretion of breast gross cystic disease fluid proteins by T47D breast cancer cells in culture-modulation by steroid hormones. Breast Cancer Res Treat. 1992;23(12):77-86.

91. Lopez-Boado YS, Puente XS, Alvarez S, Tolivia J, Binderup L, LopezOtin C. Growth inhibition of human breast cancer cells by 1,25dihydroxyvitamin D3 is accompanied by induction of apolipoprotein D expression. Cancer Res. 1997;57(18):4091-4097.

92. Lopez-Boado YS, Tolivia J, Lopez-Otin C. Apolipoprotein D gene induction by retinoic acid is concomitant with growth arrest and cell differentiation in human breast cancer cells. $J$ Biol Chem. 1994;269(43):26871-26878.

93. Lopez-Boado YS, Klaus M, Dawson MI, Lopez-Otin C. Retinoic acidinduced expression of apolipoprotein $\mathrm{D}$ and concomitant growth arrest in human breast cancer cells are mediated through a retinoic acid receptor RARalpha-dependent signaling pathway. J Biol Chem. 1996;271(50):32105-32111.

94. Diez-Itza I, Vizoso F, Merino AM, Sanchez LM, Tolivia J, Fernandez J, Ruibal A, Lopez-Otin C. Expression and prognostic significance of apolipoprotein D in breast cancer. Am J Pathol. 1994;144(2):310-320.

95. Naldoni C, Costantini M, Dogliotti L, Bruzzi P, Bucchi L, Buzzi G, Torta $M$, Angeli A. Association of cyst type with risk factors for breast cancer and relapse rate in women with gross cystic disease of the breast. Cancer Res. 1992;52(7):1791-1795.

96. Lamelas ML, Vazquez J, Enguita MI, Rodriguez JC, Gonzalez LO, Merino AM, Vizoso F. Apolipoprotein D expression in metastasic lymph nodes of breast cancer. Int J Surg Investig. 2000;2(4):285-293. 
97. Soiland H, Skaland I, Varhaug JE, Korner H, Janssen EA, Gudlaugsson E, Baak JP, Soreide JA. Co-expression of estrogen receptor alpha and Apolipoprotein $\mathrm{D}$ in node positive operable breast cancer--possible relevance for survival and effects of adjuvant tamoxifen in postmenopausal patients. Acta Oncol. 2009;48(4):514-521.

98. Jin D, El-Tanani M, Campbell FC. Identification of apolipoprotein D as a novel inhibitor of osteopontin-induced neoplastic transformation. Int J Oncol. 2006;29(6):1591-1599.

99. Rodriguez JC, Diaz M, Gonzalez LO, Sanchez J, Sanchez MT, Merino AM, Vizoso F. Apolipoprotein D expression in benign and malignant prostate tissues. Int J Surg Investig. 2000;2(4):319-326.

100. Vazquez J, Gonzalez L, Merino A, Vizoso F. Expression and clinical significance of apolipoprotein D in epithelial ovarian carcinomas. Gynecol Oncol. 2000;76(3):340-347.

101. Hunter S, Young A, Olson J, Brat DJ, Bowers G, Wilcox JN, Jaye D, Mendrinos S, Neish A. Differential expression between pilocytic and anaplastic astrocytomas: identification of apolipoprotein D as a marker for low-grade, non-infiltrating primary CNS neoplasms. J Neuropathol Exp Neurol. 2002;61(3):275-281.

102. Hunter S, Weiss S, Ou CY, Jaye D, Young A, Wilcox J, Arbiser JL, Monson D, Goldblum J, Nolen JD, Varma V. Apolipoprotein D is downregulated during malignant transformation of neurofibromas. Hum Pathol. 2005;36(9):987-993.

103. Utsunomiya $\mathrm{T}$, Ogawa $\mathrm{K}$, Yoshinaga $\mathrm{K}$, Ohta $\mathrm{M}$, Yamashita $\mathrm{K}$, Mimori $\mathrm{K}$, Inoue H, Ezaki T, Yoshikawa Y, Mori M. Clinicopathologic and prognostic values of apolipoprotein $\mathrm{D}$ alterations in hepatocellular carcinoma. Int $\mathrm{J}$ Cancer. 2005;116(1):105-109.

104. Vizoso FJ, Rodriguez M, Altadill A, Gonzalez-Dieguez ML, Linares A, Gonzalez LO, Junquera S, Fresno-Forcelledo F, Corte MD, Rodrigo L. Liver expression of steroid hormones and Apolipoprotein D receptors in hepatocellular carcinoma. World J Gastroenterol. 2007;13(23):32213227.

105. Yamashita K, Upadhyay S, Osada M, Hoque MO, Xiao Y, Mori M, Sato F, Meltzer SJ, Sidransky D. Pharmacologic unmasking of epigenetically silenced tumor suppressor genes in esophageal squamous cell carcinoma. Cancer Cell. 2002;2(6):485-495.

106. Hunter SB, Varma V, Shehata B, Nolen JD, Cohen C, Olson JJ, Ou CY. Apolipoprotein $\mathrm{D}$ expression in primary brain tumors: analysis by quantitative RT-PCR in formalin-fixed, paraffin-embedded tissue. $J$ Histochem Cytochem. 2005;53(8):963-969.

107. Soiland H, Janssen EA, Korner H, Varhaug JE, Skaland I, Gudlaugsson E, Baak JP, Soreide JA. Apolipoprotein D predicts adverse outcome in women $>$ or $=70$ years with operable breast cancer. Breast Cancer Res Treat. 2009;113(3):519-528. 
108. Provost PR, Marcel YL, Milne RW, Weech PK, Rassart E. Apolipoprotein $D$ transcription occurs specifically in nonproliferating quiescent and senescent fibroblast cultures. FEBS Lett. 1991;290(1-2):139-141.

109. Do Carmo S, Levros Jr L-C, Rassart E. Modulation of apolipoprotein D expression and translocation under specific stress conditions. Biochimica et Biophysica Acta (BBA) - Molecular Cell Research. 2007;1773(6):954969.

110. Levros Jr L-C, Carmo SD, Edouard E, Legault P, Charfi C, Rassart E. Characterization of nuclear factors modulating the apolipoprotein D promoter during growth arrest: Implication of PARP-1, APEX-1 and ERK1/2 catalytic activities. Biochimica et Biophysica Acta (BBA) Molecular Cell Research. 2010;1803(9):1062-1071.

111. Oakley AJ, Bhatia S, Ecroyd H, Garner B. Molecular dynamics analysis of apolipoprotein-d - lipid hydroperoxide interactions: mechanism for selective oxidation of met-93. PLoS One.7(3):e34057.

112. Kandel ERS, J.H. Principles of Neural Science. 2nd ed. Amsterdam: Elservier; 1985.

113. Purves DA, G.J. Fitzpatrick, D. Katz, L.C. LaMantia, A.S. McNamara, J.O. Williams, S.M. Neuroscience. Sunderland, MA, USA; 2000.

114. Drechsel DA, Patel $M$. Role of reactive oxygen species in the neurotoxicity of environmental agents implicated in Parkinson's disease. Free Radic Biol Med. 2008;44(11):1873-1886.

115. Edwards MG, Sarkar D, Klopp R, Morrow JD, Weindruch R, Prolla TA. Impairment of the transcriptional responses to oxidative stress in the heart of aged C57BL/6 mice. Ann N Y Acad Sci. 2004;1019:85-95.

116. Tomita M, Okuyama $\mathrm{T}$, Katsuyama H, Hidaka K, Otsuki T, Ishikawa T. Gene expression in rat lungs during early response to paraquat-induced oxidative stress. Int J Mol Med. 2006;17(1):37-44.

117. Tomita M, Okuyama $\mathrm{T}$, Katsuyama $\mathrm{H}$, Ishikawa $\mathrm{T}$. Paraquat-induced gene expression in rat kidney. Arch Toxicol. 2006;80(10):687-693.

118. Tomita M, Okuyama T, Katsuyama H, Miura $Y$, Nishimura $Y$, Hidaka K, Otsuki T, Ishikawa T. Mouse model of paraquat-poisoned lungs and its gene expression profile. Toxicology. 2007;231(2-3):200-209.

119. Prasad K, Tarasewicz E, Mathew J, Strickland PAO, Buckley B, Richardson JR, Richfield EK. Toxicokinetics and toxicodynamics of paraquat accumulation in mouse brain. Experimental Neurology. 2009;215(2):358-367.

120. Bus JS, Gibson JE. Paraquat: model for oxidant-initiated toxicity. Environ Health Perspect. 1984;55:37-46.

121. Brooks AI, Chadwick CA, Gelbard HA, Cory-Slechta DA, Federoff HJ. Paraquat elicited neurobehavioral syndrome caused by dopaminergic neuron loss. Brain Res. 1999;823(1-2):1-10. 
122. Gonzalez-Polo RA, Rodriguez-Martin A, Moran JM, Niso M, Soler G, Fuentes JM. Paraquat-induced apoptotic cell death in cerebellar granule cells. Brain Res. 2004;1011(2):170-176.

123. Apps R, Garwicz M. Anatomical and physiological foundations of cerebellar information processing. Nat Rev Neurosci. 2005;6(4):297-311.

124. Navarro A, Del Valle E, Tolivia J. Differential expression of apolipoprotein $\mathrm{d}$ in human astroglial and oligodendroglial cells. J Histochem Cytochem. 2004;52(8):1031-1036.

125. Schipper HM. Astrocytes in Brain Aging and Neurodegeneration. 1st Edition ed. Georgetown, Texas, USA: Landes company; 1998.

126. Newman EA. New roles for astrocytes: regulation of synaptic transmission. Trends Neurosci. 2003;26(10):536-542.

127. Finkbeiner SM. Glial calcium. Glia. 1993;9(2):83-104.

128. Porter JT, McCarthy KD. Hippocampal astrocytes in situ respond to glutamate released from synaptic terminals. $J$ Neurosci. 1996;16(16):5073-5081.

129. Kang J, Jiang L, Goldman SA, Nedergaard M. Astrocyte-mediated potentiation of inhibitory synaptic transmission. Nat Neurosci. 1998;1(8):683-692.

130. Araque A, Martin ED, Perea G, Arellano JI, Buno W. Synaptically released acetylcholine evokes $\mathrm{Ca} 2+$ elevations in astrocytes in hippocampal slices. J Neurosci. 2002;22(7):2443-2450.

131. Volterra A, Steinhauser C. Glial modulation of synaptic transmission in the hippocampus. Glia. 2004;47(3):249-257.

132. Perea G, Navarrete M, Araque A. Tripartite synapses: astrocytes process and control synaptic information. Trends Neurosci. 2009;32(8):421-431.

133. Araque A, Sanzgiri RP, Parpura V, Haydon PG. Astrocyte-induced modulation of synaptic transmission. Can $J$ Physiol Pharmacol. 1999;77(9):699-706.

134. Navarrete $M$, Araque A. Endocannabinoids mediate neuron-astrocyte communication. Neuron. 2008;57(6):883-893.

135. Navarrete $M$, Araque A. Endocannabinoids potentiate synaptic transmission through stimulation of astrocytes. Neuron.68(1):113-126.

136. Liddell JR, Robinson SR, Dringen R, Bishop GM. Astrocytes retain their antioxidant capacity into advanced old age. Glia. 2010;58(12):15001509.

137. Pekny M, Nilsson M. Astrocyte activation and reactive gliosis. Glia. 2005;50(4):427-434.

138. Sofroniew MV. Molecular dissection of reactive astrogliosis and glial scar formation. Trends in Neurosciences. 2009;32(12):638-647. 
139. Siegel GJA, B.W. Albers, R.W. Fisher, S.K. Uhler, M.D. Basic Neurochemistry, Molecular, Cellular and Medical Aspects. 6th Edition ed. Philadelphia: Lippincott-Raven; 1999.

140. Kalla S, Stern M, Basu J, Varoqueaux F, Reim K, Rosenmund C, Ziv NE, Brose N. Molecular dynamics of a presynaptic active zone protein studied in Munc13-1-enhanced yellow fluorescent protein knock-in mutant mice. J Neurosci. 2006;26(50):13054-13066.

141. Miller RL, James-Kracke M, Sun GY, Sun AY. Oxidative and inflammatory pathways in Parkinson's disease. Neurochem Res. 2009;34:55-65.

142. Morale MC, Serra PA, L'Episcopo F, Tirolo C, Caniglia S, Testa N, Gennuso F, Giaquinta G, Rocchitta G, Desole MS, Miele E, Marchetti B. Estrogen, neuroinflammation and neuroprotection in Parkinson's disease: Glia dictates resistance versus vulnerability to neurodegeneration. Neuroscience. 2006;138(3):869-878.

143. Song YJC, Halliday GM, Holton JL, Lashley T, O'Sullivan SnS, McCann $\mathrm{H}$, Lees AJ, Ozawa T, Williams DR, Lockhart PJ, Revesz TR. Degeneration in Different Parkinsonian Syndromes Relates to Astrocyte Type and Astrocyte Protein Expression. Journal of Neuropathology \& Experimental Neurology. 2009;68(10):1073-1083.

144. Petrucelli L, O'Farrell C, Lockhart PJ, Baptista M, Kehoe K, Vink L, Choi P, Wolozin B, Farrer M, Hardy J, Cookson MR. Parkin protects against the toxicity associated with mutant alpha-synuclein: proteasome dysfunction selectively affects catecholaminergic neurons. Neuron. 2002;36(6):1007-1019.

145. Imai $\mathrm{Y}$, Soda $\mathrm{M}$, Takahashi $\mathrm{R}$. Parkin suppresses unfolded protein stress-induced cell death through its E3 ubiquitin-protein ligase activity. $J$ Biol Chem. 2000;275(46):35661-35664.

146. Imai $\mathrm{Y}$, Soda $\mathrm{M}$, Inoue $\mathrm{H}$, Hattori N, Mizuno $\mathrm{Y}$, Takahashi R. An unfolded putative transmembrane polypeptide, which can lead to endoplasmic reticulum stress, is a substrate of Parkin. Cell. 2001;105(7):891-902.

147. Miller DB, O'Callaghan JP. Do early-life insults contribute to the late-life development of Parkinson and Alzheimer diseases? Metabolism. 2008;57 Suppl 2:S44-49.

148. Finsterer J. Parkinson's syndrome and Parkinson's disease in mitochondrial disorders. Mov Disord.26(5):784-791.

149. Gasser T. Molecular pathogenesis of Parkinson disease: insights from genetic studies. Expert Rev Mol Med. 2009;11:e22.

150. Sandebring $A$, Thomas $K J$, Beilina $A$, van der Brug $M$, Cleland MM, Ahmad R, Miller DW, Zambrano I, Cowburn RF, Behbahani H, CedazoMinguez A, Cookson MR. Mitochondrial alterations in PINK1 deficient cells are influenced by calcineurin-dependent dephosphorylation of dynamin-related protein 1. PLoS One. 2009;4(5):e5701. 
151. Haque ME, Thomas KJ, D'Souza C, Callaghan S, Kitada T, Slack RS, Fraser P, Cookson MR, Tandon A, Park DS. Cytoplasmic Pink1 activity protects neurons from dopaminergic neurotoxin MPTP. Proc Natl Acad Sci U S A. 2008;105(5):1716-1721.

152. Zhang L, Shimoji M, Thomas B, Moore DJ, Yu SW, Marupudi NI, Torp R, Torgner IA, Ottersen OP, Dawson TM, Dawson VL. Mitochondrial localization of the Parkinson's disease related protein DJ-1: implications for pathogenesis. Hum Mol Genet. 2005;14(14):2063-2073.

153. Canet-Aviles RM, Wilson MA, Miller DW, Ahmad R, McLendon C, Bandyopadhyay S, Baptista MJ, Ringe D, Petsko GA, Cookson MR. The Parkinson's disease protein DJ-1 is neuroprotective due to cysteinesulfinic acid-driven mitochondrial localization. Proc Natl Acad Sci U S A. 2004;101(24):9103-9108.

154. Casarejos MJ, Menendez J, Solano RM, Rodriguez-Navarro JA, Garcia de Yebenes J, Mena MA. Susceptibility to rotenone is increased in neurons from parkin null mice and is reduced by minocycline. $J$ Neurochem. 2006;97(4):934-946.

155. Paterna JC, Leng A, Weber E, Feldon J, Bueler H. DJ-1 and Parkin modulate dopamine-dependent behavior and inhibit MPTP-induced nigral dopamine neuron loss in mice. Mol Ther. 2007;15(4):698-704.

156. Sandebring A, Dehvari N, Perez-Manso M, Thomas KJ, Karpilovski E, Cookson MR, Cowburn RF, Cedazo-Minguez A. Parkin deficiency disrupts calcium homeostasis by modulating phospholipase $\mathrm{C}$ signalling. FEBS J. 2009;276(18):5041-5052.

157. Gautier CA, Kitada T, Shen J. Loss of PINK1 causes mitochondrial functional defects and increased sensitivity to oxidative stress. Proc Natl Acad Sci U S A. 2008;105(32):11364-11369.

158. Palacino JJ, Sagi D, Goldberg MS, Krauss S, Motz C, Wacker M, Klose $\mathrm{J}$, Shen J. Mitochondrial dysfunction and oxidative damage in parkindeficient mice. J Biol Chem. 2004;279(18):18614-18622.

159. Liu W, Vives-Bauza C, Acin-Perez R, Yamamoto A, Tan Y, Li Y, Magrane J, Stavarache MA, Shaffer S, Chang S, Kaplitt MG, Huang XY, Beal MF, Manfredi G, Li C. PINK1 defect causes mitochondrial dysfunction, proteasomal deficit and alpha-synuclein aggregation in cell culture models of Parkinson's disease. PLoS One. 2009;4(2):e4597.

160. Mitchell RM. Compendio de ROBBINS \& COTRAN. Patología estructural $y$ funcional. 7th Edition ed: Elservier; 2007.

161. Kufe DWP, R.E. Weichselbaum, R.R. Bast Jr, R.C. Gansler, T.S. Holland, J.F. Frei, E. Holland-Frei Cancer Medicine. Vol Hamilton (ON), Canada. 6th edition ed: BC Decker; 2003.

162. Feron O. Pyruvate into lactate and back: from the Warburg effect to symbiotic energy fuel exchange in cancer cells. Radiother Oncol. 2009;92(3):329-333. 
163. Roudier E, Perrin A. Considering the role of pyruvate in tumor cells during hypoxia. Biochim Biophys Acta. 2009;1796(2):55-62.

164. Vander Heiden MG, Cantley LC, Thompson CB. Understanding the Warburg effect: the metabolic requirements of cell proliferation. Science. 2009;324(5930):1029-1033.

165. Janssen AM, Bosman CB, Sier CF, Griffioen G, Kubben FJ, Lamers CB, van Krieken $\mathrm{JH}$, van de Velde CJ, Verspaget HW. Superoxide dismutases in relation to the overall survival of colorectal cancer patients. $\mathrm{Br} J$ Cancer. 1998;78(8):1051-1057.

166. Schumacker PT. Reactive oxygen species in cancer cells: live by the sword, die by the sword. Cancer Cell. 2006;10(3):175-176.

167. Hendrickse CW, Kelly RW, Radley S, Donovan IA, Keighley MR, Neoptolemos JP. Lipid peroxidation and prostaglandins in colorectal cancer. Br J Surg. 1994;81(8):1219-1223.

168. Ozdemirler G, Pabuccuoglu H, Bulut T, Bugra D, Uysal M, Toker G. Increased lipoperoxide levels and antioxidant system in colorectal cancer. J Cancer Res Clin Oncol. 1998;124(10):555-559.

169. Lauschke H, Tolba R, Burger B, Minor T, Hirner A. Lipid peroxidation as additional marker in patients with colorectal cancer. Results of a preliminary study. Eur Surg Res. 2002;34(5):346-350.

170. Farias IL, Farias JG, Rossato L, Araujo MC, Chiesa J, Morsh V, Schetinger MR. Correlation between TBARS levels and glycolytic enzymes: the importance to the initial evaluation of clinical outcome of colorectal cancer patients. Biomed Pharmacother. 2011;65(6):395-400.

171. Ogawa K, Utsunomiya T, Mimori K, Yamashita K, Okamoto M, Tanaka F, Inoue H, Ikeda Y, Saku M, Murayama S, Mori M. Genomic screens for genes upregulated by demethylation in colorectal cancer: possible usefulness for clinical application. Int J Oncol. 2005;27(2):417-426.

172. Sasaki $Y$, Negishi $H$, Koyama R, Anbo N, Ohori K, Idogawa M, Mita H, Toyota M, Imai K, Shinomura Y, Tokino T. p53 family members regulate the expression of the apolipoprotein $D$ gene. $J$ Biol Chem. 2009;284(2):872-883.

173. Terman A, Brunk UT. Oxidative stress, accumulation of biological 'garbage', and aging. Antioxid Redox Signal. 2006;8(1-2):197-204.

174. Chinopoulos C, Adam-Vizi V. Calcium, mitochondria and oxidative stress in neuronal pathology. Novel aspects of an enduring theme. FEBS J. 2006;273(3):433-450.

175. Juranek I, Bezek S. Controversy of free radical hypothesis: reactive oxygen species--cause or consequence of tissue injury? Gen Physiol Biophys. 2005;24(3):263-278.

176. Wada T, Penninger JM. Mitogen-activated protein kinases in apoptosis regulation. Oncogene. 2004;23(16):2838-2849. 
177. England K, Cotter TG. Direct oxidative modifications of signalling proteins in mammalian cells and their effects on apoptosis. Redox Rep. 2005;10(5):237-245.

178. Gupta S, Campbell D, Derijard B, Davis RJ. Transcription factor ATF2 regulation by the JNK signal transduction pathway. Science. 1995;267(5196):389-393.

179. Karin $M$. The regulation of AP-1 activity by mitogen-activated protein kinases. J Biol Chem. 1995;270(28):16483-16486.

180. Maundrell K, Antonsson B, Magnenat E, Camps M, Muda M, Chabert C, Gillieron C, Boschert U, Vial-Knecht E, Martinou JC, Arkinstall S. Bcl-2 undergoes phosphorylation by c-Jun $\mathrm{N}$-terminal kinase/stress-activated protein kinases in the presence of the constitutively active GTP-binding protein Rac1. J Biol Chem. 1997;272(40):25238-25242.

181. Seimiya H, Mashima T, Toho M, Tsuruo T. c-Jun NH2-terminal kinasemediated activation of interleukin-1beta converting enzyme/CED-3-like protease during anticancer drug-induced apoptosis. J Biol Chem. 1997;272(7):4631-4636.

182. Johnstone RW, Ruefli AA, Lowe SW. Apoptosis: a link between cancer genetics and chemotherapy. Cell. 2002;108(2):153-164.

183. Thompson CB. Apoptosis in the pathogenesis and treatment of disease. Science. 1995;267(5203):1456-1462.

184. Attardi LD, Jacks $T$. The role of p53 in tumour suppression: lessons from mouse models. Cell Mol Life Sci. 1999;55(1):48-63. 

3. Objetivos 



\section{Objetivos}

El estrés oxidativo es un fenómeno concomitante tanto en el envejecimiento como en determinadas patologías con alta asociación a la edad como factor de riesgo (neurodegenerativas, metabólicas o cáncer). La expresión de ApoD esta fuertemente correlacionada con el envejecimiento y con este amplio grupo de patologías de gran interés biomédico. El promotor del gen de ApoD tiene elementos de respuesta a estrés, y sin embargo no está aún claro el papel que desempeña en dichas situaciones.

La hipótesis de partida, derivada de los antecedentes, es que ApoD desempeña un papel protector en todas estas situaciones, fisiológicas o patológicas. Sin embargo esta hipótesis no estaba definitivamente demostrada.

Diseñamos este trabajo para dilucidar la función de ApoD en células sometidas a estrés oxidativo y para cuestionar si dicha función es generalizable a distintos tipos celulares y tejidos diferentes. Ya que la expresión de ApoD y sus efectos podrían ser a priori muy diferentes en células proliferativas y en células quiescentes, nos planteamos un plan de trabajo siguiendo dos objetivos generales:

a) Realizar un estudio de la respuesta y los cambios propiciados por la ausencia o presencia de $A p o D$ en un contexto de estrés oxidativo en el sistema nervioso, como paradigma representativo de células post-mitóticas quiescentes.

b) Realizar un estudio de la expresión de ApoD y de otros genes relacionados con el estrés oxidativo en células tumorales usando tejido de pacientes con cáncer colorrectal, como modelo de células en estado proliferativo. 
Para ellos nos plantemos los siguientes objetivos concretos:

Objetivo 1. Estudiar cómo cambia la respuesta temprana del sistema nervioso ante el estrés oxidativo en ausencia de ApoD o ante la sobreexpresión de ApoD, como paradigma para dilucidar los efectos de ApoD sobre el tejido nervioso completo.

Objetivo 2. Determinar cómo se controla la expresión de ApoD en respuesta al estrés oxidativo en uno de los tipos celulares más productores de ApoD en el sistema nervioso (los astrocitos), y cuestionar si su expresión contribuye a mejorar la resistencia de estas células gliales, su nivel de reactividad y su contribución al mantenimiento de los sistemas dopaminérgicos frente al estrés oxidativo.

Objetivo 3. Comprobar si ApoD tiene un impacto en la vulnerabilidad de neuronas que modelan in vitro a la enfermedad de Parkinson mediante mutaciones de pérdida de función del gen PINK1, uno de los genes relevantes en la patogenia del Parkinson familiar.

Objetivo 4. Verificar el cambio de expresión de ApoD a lo largo de los distintos estadios de un tipo de cáncer asociado al envejecimiento, el cáncer colorrectal, así como estudiar la expresión de otros genes relacionados con el estrés oxidativo, de forma que podamos deducir si en esta patología ApoD se comporta como parte de la respuesta de protección del tejido. 
4. Resultados 



\section{Resultados}

\subsection{A ApoD function in the early transcriptional response to oxidative stress in the cerebellum (Objective 1).}

This objective aimed at determining the early response of nervous system against oxidative stress in the absence of ApoD and in the presence of excess ApoD (overexpression of human ApoD panneuronally), to test the effects of ApoD on the nervous system.

The results concerning this objective are contained in the publication

- Bajo-Grañeras, Sanchez D, Gutierrez G, González C, Do Carmo

S, Rassart E, Ganfornina MD

- Apolipoprotein $D$ alters the early transcriptional response to oxidative stress in the adult cerebellum

- Journal of Neurochemistry 2011 Jun;117(6):949-60

attached below. 



\subsection{B Función de ApoD en la respuesta transcripcional temprana al estrés oxidativo en el cerebelo (Objetivo 1).}

Este objetivo consistía en determinar la respuesta temprana del sistema nervioso ante el estrés oxidativo en ausencia de ApoD o ante la sobreexpresión de ApoD, para comprobar los efectos de ApoD sobre el tejido nervioso.

Los resultados relativos a este objetivo están contenidos en la publicación

- Bajo-Grañeras, Sanchez D, Gutierrez G, González C, Do Carmo

S, Rassart E, Ganfornina MD.

- Apolipoprotein $D$ alters the early transcriptional response to oxidative stress in the adult cerebellum.

- Journal of Neurochemistry 2011 Jun;117(6):949-60

que se adjunta a continuación.

Presento aquí un estudio del efecto que ejerce ApoD sobre los cambios en el perfil transcripcional que tienen lugar de manera temprana ante el estrés oxidativo en el cerebelo del ratón. Para esto hemos usado la tecnología de micro-matrices de expresión génica. Hemos comparado la respuesta que se obtiene en los ratones silvestres con la respuesta que se obtiene en los mutantes de pérdida de función (ApoD-KO) y la que se obtiene en los transgénicos que sobre-expresan ApoD en neuronas (Tg-hApoD).

Hemos comprobado que en condiciones basales, ApoD afecta al perfil transcripcional de genes específicos de neuronas y oligodendrocitos relacionados con la excitabilidad neuronal, la función sináptica y la homeostasis de la mielina. 
Cuando los ratones deficientes en $A p o D$ se someten a tratamiento con $P Q$, se observa una modificación de la respuesta, principalmente en genes relacionados con el manejo del estrés oxidativo y de la mielinización.

Los individuos que presentan sobre-expresión de ApoD responden de manera muy interesante al estrés oxidativo, aboliendo casi por completo la respuesta temprana que tiene lugar en las neuronas en situación control.

Los resultados que se obtienen en esta sección apoyan la hipótesis de que ApoD es necesaria para una respuesta apropiada del sistema nervioso contra el estrés oxidativo fisiológico o patológico. 


\title{
Apolipoprotein $D$ alters the early transcriptional response to oxidative stress in the adult cerebellum
}

\author{
Raquel Bajo-Grañeras, ${ }^{*}$ Diego Sanchez, ${ }^{* 1}$ Gabriel Gutierrez, $\dagger$ Constancio González, ${ }^{*}+$ \\ Sonia Do Carmo, $\S$ Eric Rassart $\S$ and Maria D. Ganfornina*,1 \\ *Departamento de Bioquímica y Biología Molecular y Fisiología-IBGM, Universidad de Valladolid-CSIC, Valladolid, Spain \\ $\uparrow$ Departamento de Genética, Universidad de Sevilla, Sevilla, Spain \\ $\$$ CIBER de enfermedades respiratorias, Instituto de Salud Carlos III, Madrid, Spain. \\ $\S$ Département des Sciences Biologiques, Centre BioMed, Université du Québec à Montréal, Montréal, Canada
}

\begin{abstract}
The lipocalin Apolipoprotein D (ApoD), known to protect the nervous system against oxidative stress (OS) in model organisms, is up-regulated early in the mouse brain in response to the ROS generator paraquat. However, the processes triggered by this up-regulation have not been explored. We present here a study of the effect of $A p o D$ on the early transcriptional changes upon $\mathrm{OS}$ in the mouse cerebellum using microarray profiling. ApoD-KO and transgenic mice over-expressing $A p o D$ in neurons are compared to wild-type controls. In control conditions, $A p o D$ affects the transcriptional profile of neuron and oligodendrocyte-specific genes involved in neuronal excitability, synaptic function, and myelin homeostasis. When challenged with paraquat, the absence of
\end{abstract}

$A p o D$ modifies the response of genes mainly related to OS management and myelination. Interestingly, the over-expression of $A p o D$ in neurons almost completely abolishes the early transcriptional response to OS. We independently evaluate the expression of protein kinase $\mathrm{C} \delta$, a gene up-regulated by OS only in the ApoD-KO cerebellum, and find it overexpressed in cultured ApoD-KO primary astrocytes, which points to a role for $A p o D$ in astrocyte-microglia signaling. Our results support the hypothesis that $A p o D$ is necessary for a proper response of the nervous system against physiological and pathological OS.

Keywords: astrocytes, lazarillo, lipocalin, oligodendrocytes, paraquat, $\mathrm{Pkc} \delta$.

J. Neurochem. (2011) 117, 949-960.
Cells in the nervous system (NS) are exposed to a strong and constant production of reactive oxygen and nitrogen species (RS) because of their highly demanding metabolism. This oxidative load is tightly regulated to sustainable limits by an effective array of antioxidant proteins and compounds. However, physiological aging and a number of genetic and environmentally-induced degenerative diseases affect both the production and the clearance of RS. The subsequent oxidative stress (OS) clearly contributes to the pathogenic mechanisms underlying these conditions.

As a way of studying the antioxidant mechanisms participating in NS homeostatic regulation, several methods of RS induction have been used. Some of these methods, involving treatments with drugs such as MPTP, maneb and paraquat (PQ; 1,1'-dimethyl-4,4'-bipyridinium), in model organisms are able to totally or partially mimic the signs and symptoms of a devastating neurodegenerative process such as Parkinson's disease (Drechsel and Patel 2008).
The extensive work of several groups with these compounds has uncovered the detailed process of the response of the NS to the experimentally-induced OS. The treatment with chronic sublethal doses of these compounds elicits NS specific responses that are generated by the different cell types involved. Early responses to PQ in gene expression

Received January 31, 2011; revised manuscript received March 16, 2011; accepted March 31, 2011.

Address correspondence and reprint requests to Maria D. Ganfornina and D. Sanchez, Instituto de Biología y Genética Molecular, c/Sanz y Forés 3, Universidad de Valladolid-CSIC, 47003 Valladolid, Spain. E-mail: opabinia@ibgm.uva.es

${ }^{1}$ These authors contributed equally to this study.

Abbreviations used: ApoD, Apolipoprotein D; FC, fold change; FDR, false discovery rate; GC, GeneChip; GO, gene ontology; hApoD, human ApoD; KO, knock-out; NS, nervous system; OS, oxidative stress; Pkc $\delta$, Protein kinase $\mathrm{C} \delta$; $\mathrm{PQ}$, paraquat; RMA, robust multiarray average algorithm; RS, reactive species; Tg, transgenic; WT, wild-type. 
have been reported for non-neural tissues (Edwards et al. 2004; Tomita et al. 2006, 2007), but no study has been performed in the NS.

Our laboratory studies the role in the nervous system of the gene Apolipoprotein D $(A p o D)$ and its homologs in Drosophila melanogaster. Using experimentally-induced OS by PQ treatment, we have demonstrated that $A p o D$ has protective effects over the organism survival both in mouse and flies, and that it helps to maintain the NS tissue homeostasis by maintaining low levels of lipid peroxidation (Sanchez et al. 2006; Ganfornina et al. 2008; Hull-Thompson et al. 2009). ApoD mRNA expression is transiently induced in the mouse brain upon PQ treatment with an early peak at $3 \mathrm{~h}$, and this up-regulation is specific for the neural tissue (Ganfornina et al. 2008).

We have previously analyzed how the lack of $A p o D$ generates specific imbalances in the transcriptional response of peripheral nerves upon injury, indicating that at least part of the complex response to injury is modulated by $A p o D$ (Ganfornina et al. 2010). However, whether ApoD is also an important contributor shaping the early transcriptional response of the CNS to OS is still unknown. In this work, we analyze the transcriptional profile of PQ-challenged cerebellum of wild-type (WT), ApoD loss-of-function [ApoDknock-out (KO)] and transgenic mice over-expressing human $A p o D$ in neurons (hApoD-Tg) using oligonucleotide microarray technology. Besides its function in motor coordination and learning, the cerebellum is a OS-sensitive brain region found to be altered in aging and many NS pathologies (Apps and Garwicz 2005).

The alteration of $A p o D$ expression results in transcriptional changes of genes involved in neuron electrical activity and synaptic function, and in myelin homeostasis. In addition, $A p o D$ regulates the expression of several genes that control the cellular response to environmental stimuli such as OS. On the other hand, the expression profile of the OSchallenged cerebellum shows a number of genes with ApoD-dependent expression that, aside of OS management, are related to nervous system development, cell differentiation and the myelination process. Our results support the hypothesis that the presence of $A p o D$ in the nervous system is necessary for a proper response against physiological and pathological OS.

\section{Experimental procedures}

\section{Animals and cell cultures}

In this study, we used adult ( $80 \pm 5$ days old) male mice of three genotypes: ApoD-KO, hApoD-Tg and their WT littermates. The loss-of-function mutant ApoD-KO mice were generated by homologous recombination, and the mutation is evidenced by PCRgenotyping with two different primer pairs as described previously (Ganfornina et al. 2008). The gain-of-function mutant hApoD-Tg mice over-express the human $A p o D$ gene under the control of the neuron-specific Thy-1 promoter, and their characterization and genotyping procedures have been already reported (Ganfornina et al. 2008; Do Carmo et al. 2009). In order to avoid potential maternal effects of ApoD and to generate WT and ApoD-KO cohorts of homogeneous genetic background, the experimental cohorts used in this study are the F1 generation of homozygous crosses of each genotype. The parental generation was composed of $A p o D-/-$ and ApoD $+/+$ littermates from heterozygous crosses of the ApoD-KO line. The hApoD-Tg animals used in this study were heterozygous mutants. Both mutations have been backcrossed $>11$ generations into the $\mathrm{C} 57 \mathrm{Bl} / 6 \mathrm{~J}$ genetic background.

All mice were housed in positive pressure-ventilated racks at $25 \pm 1^{\circ} \mathrm{C}$ with a $12 \mathrm{~h} \mathrm{light/dark} \mathrm{cycle,} \mathrm{fed} \mathrm{ad} \mathrm{libitum} \mathrm{with} \mathrm{a} \mathrm{standard}$ rodent pellet diet (Global Diet 2014; Harlan Inc., Indianapolis, IN, USA), and allowed free access to filtered and UV-irradiated water. Experimental procedures were approved by the Animal Care and Use Committees of the University of Valladolid (UVa) and Université du Québec à Montréal (UQAM) and were in accordance with the Guidelines for the Care and Use of Mammals in Research (European Commission Directive 86/609/CEE and Spanish Royal Decree 1201/2005).

Primary glial cultures were prepared from the cortices of neonatal (P0) mice, treated with $10 \mathrm{mg} / \mathrm{mL}$ trypsin for $15 \mathrm{~min}$ at $37^{\circ} \mathrm{C}$, mechanically dissociated, and incubated in Dulbecco's Modified Eagle's medium supplemented with $10 \%$ fetal bovine serum (FBS), $1 \%$ L-Glutamine and $1 \%$ Penicillin $(10 \mathrm{U} / \mu \mathrm{L})$ - Streptomycin $(10 \mu \mathrm{g} / \mu \mathrm{L})-$ Amphotericyn B $(25 \mu \mathrm{g} / \mathrm{mL})$ at $37^{\circ} \mathrm{C}$ in $5 \% \mathrm{CO}_{2}$ with $90-95 \%$ humidity. The medium was weekly replaced, and after $2-3$ subculture steps, over $95 \%$ of type 1 astrocytes were present, as estimated by glial fibrillary acidic protein (GFAP) labeling and by morphological criteria. The cultures had a minor contribution of microglial cells (Cd11b marker). Oligodendrocytes were not detected (pi-GST marker).

Experimental oxidative stress treatments and tissue collection Nine mice of each genotype were either treated with a single intraperitoneal injection of PQ $(30 \mathrm{mg} / \mathrm{kg})$ in $200 \mu \mathrm{L}$ sterile saline (Experimental group), or a similar volume of sterile saline (Control group). Six hours after injection, each mouse was killed with $\mathrm{CO}_{2}$ and the cerebellum was immediately removed and frozen.

In the chronically treated cohort, male mice $(n=6 /$ genotype for PQ and $n=4 /$ genotype for control) were injected intraperitoneally with $10 \mathrm{mg} / \mathrm{kg}$ PQ or phosphate-buffered saline for a total of seven injections (two per week for the first 2 weeks, one per week for three additional weeks). Tissue collection was carried out 7 days after last injection.

Paraquat injections were performed by the same experimenter to minimize differences in animal stress. The brain samples were extracted at the same time of the day in order to avoid gene expression variations due to circadian rhythms.

\section{RNA purification, microarray hybridization and processing} Tissue was homogenized in TRIzol (Invitrogen, Barcelona, Spain), and total RNA extracted according to the manufacturer procedure. A second purification using the RNeasy miniKit (Qiagen Iberia, Madrid, Spain) was employed to prepare the Array probes from high-quality RNA samples, as assayed using the Agilent 2100 Bioanalyzer (Agilent Technologies, Madrid, Spain). Equimolar 
amounts of total RNA from three randomly selected mice for each genotype and experimental condition were pooled, rendering three biological replicates to hybridize with the arrays.

cDNA was synthesized and purified from $5 \mu \mathrm{g}$ of each RNA sample with the One Cycle cDNA synthesis (Affymetrix, Santa Clara, CA, USA). The generation, labeling and purification of cRNA was performed using the IVT kit (Affymetrix).

Ten micrograms of the biotinylated and fragmented probes were hybridized to Affymetrix GeneChip Mouse Genome 430A 2.0 arrays (Lot \# 4029603) at $45^{\circ} \mathrm{C}$ for $16 \mathrm{~h}$, following the manufacturer's protocols. After washes, the arrays were incubated with antibiotin streptavidin-phycoeritrin antibody and scanned with an Affymetrix GeneChip Scanner 7G. Probe synthesis and hybridizations were performed at the Genomics facility of the Centro de Investigacion del Cancer (Salamanca, Spain).

\section{Microarray data analysis}

The analysis of gene expression and the comparative expression between genotype and experimental conditions were performed using the Affymetrix CEL files and both, the GEPAS platform (Tarraga et al. 2008) and the FlexArray v1.4.1 program (Blazejczyk et al. 2007). The original CEL files are available at the GEO Database (Accession number GSE28643).

Robust normalization using MAS 5.0 (Affymetrix) was performed to estimate a change $p$-value and its associated change call in gene expression for each probeset. Data pre-processing was carried out with FlexArray using the robust multiarray average algorithm (RMA) and GeneChip RMA (GC-RMA) algorithms with background corrections and normalization, and with GEPAS using RMA-quantiles for background correction and normalization. Only perfect-match probesets were considered in both analyses.

Differentially expressed genes were evaluated with FlexArray by two sample comparisons with the cyberT-test (Baldi and Long 2001), using a threshold of 2-fold change (FC) and a $p$-value $<0.05$. False discovery rate (FDR) correction was performed using the Benjamini-Hochberg method. ANOVA was performed on the GC-RMA processed probes with $\mathrm{FDR}=1 \%$ to further select candidate genes specifically affected by PQ treatment and/or genotype. ANOVA was also selected in GEPAS to study FDRcorrected differentially expressed genes with a FC $\geq \pm 2$ cut-off value and an adjusted $p$-value $<0.05$. Genes that showed consensus expression changes by ANOVA and cyberT-test were selected for further study.

As a final filter for analyzing genes whose expression is affected by the levels of $A p o D$, we compared the list of genes generated with the RMA/GC-RMA/cyberT/ANOvA lists generated by FlexArray and the GEPAS analysis platform. From a consensus analysis we selected the genes for further exploration. Probe sets derived from uncharacterized genes were not considered for the final discussion of differentially expressed genes.

The genes selected from our microarray analysis were subjected to gene ontology (GO) and pathway analyses. Results coming from the two background correction and normalization procedures were compared, and genes that showed expression changes under both methods were considered for discussion and future experimental analysis.

Data mining with GO classification of the selected transcripts and GO comparisons between datasets were carried out with the
GOEAST (http://omicslab.genetics.ac.cn/GOEAST/) and DAVID 6.7 platforms (http://david.abcc.ncifcrf.gov/home.jsp) (Zheng and Wang 2008; Huang da et al. 2009). Pathway analysis was performed using MouseNet (http://avis.princeton.edu/mouseNET/index.php).

A meta-analysis of microarray studies reporting transcriptional changes induced by OS was performed by using the LOLA database and analysis software (http://lola.gwu.edu/) (Cahan et al. 2005) to compare gene transcriptional changes with a statistical assessment of the congruencies or differences.

We also performed a comparison of the gene sets obtained in our study with the genes reported to be cell-type enriched in the nervous system (2618 astrocyte-enriched genes, 2036 neuron-enriched genes, and 2228 oligodendrocyte-enriched genes) by Cahoy et al. (2008).

\section{Quantitative real-time RT-PCR}

RNAs for qRT-PCR experiments were extracted with TRIzol (Invitrogen) either from the pooled samples of mouse cerebella described above, from homogenized mouse diencephalons, or from cultured astroglial cells. Total RNA $(1 \mu \mathrm{g})$ was reverse-transcribed with PrimeScript ${ }^{\mathrm{TM}}$ (Takara Bio Inc., Otsu, Japan) and treated with DNaseI. The cDNA obtained was used as template for qRT-PCR using SybrGreen $\left(\right.$ SYBR $^{\circledR}$ Premix Ex Taq ${ }^{\mathrm{TM}}$ kit, Takara) amplifications. The oligonucleotide primers used in our amplifications are shown in Table S2. The gene Rpll 8 was used as a reference because neither genotype nor treatment gives a significant fold change for this gene.

Amplifications were performed in quadruplicate in an ABI Prism 7900 HT or a Rotor-Gene RG-3000 (Corbett-Qiagen Iberia) thermal cycler. Standard cycling conditions were: $95^{\circ} \mathrm{C}, 5 \mathrm{~min}$; 40 cycles $\left(95^{\circ} \mathrm{C}, 30 \mathrm{~s} ; 60^{\circ} \mathrm{C}, 1 \mathrm{~min}\right)$.

Changes in transcriptional expression were estimated with the $\Delta \Delta C_{\mathrm{T}}$ method (Livak and Schmittgen 2001). The following criteria were applied to our amplifications: (i) Replicates with variation coefficient $>2.5 \%$ were excluded; (ii) Undetermined $C_{\mathrm{T}}$ values (gene expression below detection levels) were assigned $C_{\mathrm{T}}=35$; (iii) Pairwise comparisons where the gene average $C_{\mathrm{T}}>35$ cycles in both conditions were excluded from the analysis; (iv) Only transcriptional changes greater than or equal to twofold were included in the analysis. Significant differences of gene transcriptional changes were evaluated with a Mann-Whitney $U$-test (Yuan et al. 2006), using the $\Delta C_{\mathrm{T}}$ of each replica. Values are expressed as mean $\log _{2}{ }^{-\Delta \Delta C t} \pm \mathrm{SD}$, and the level of significance was set at $p<0.05$. Only statistically significant differences of expression are presented in results and discussed in the text.

\section{Immunoblot experiments}

Brain tissue was homogenized in lysis buffer [1\% Nonidet P-40 (Calbiochem, Merck KGaA, Darmstadt, Germany), 0.1\% sodium dodecyl sulfate, $0.5 \%$ sodium deoxycholate, and $10 \%$ Complete Protease Inhibitors (Roche Molecular Biochemicals, Indianapolis, IN, USA) in phosphate-buffered saline], cleared by centrifugation, and the supernatant was stored at $-80^{\circ} \mathrm{C}$.

Protein concentration was determined with Micro-BCA ${ }^{\mathrm{TM}}$ protein assay (Pierce, Rockford, IL, USA). Immunoblot analyses were performed with $10-20 \mu \mathrm{g}$ of total protein/lane transferred to polyvinylidene difluoride membranes using standard procedures. We used the following primary antibodies: Rabbit serum anti-MBP (Abcam plc, Cambridge, UK); Goat serum anti-mouse ApoD (Santa Cruz, CA, USA). Secondary horseradish peroxidase-conjugated 
Goat anti-Rabbit or Donkey anti-goat IgG (Santa Cruz) were used. Protein loads were normalized with the signal obtained with a horseradish peroxidase-conjugated anti- $\beta$ actin antibody (Sigma, St Louis, MO, USA). Membranes were developed with ECL (Millipore, Billerica, MA, USA). The integrated optical density of the immunoreactive protein bands was measured in images taken within the linear range of the digital camera (VersaDoc, Bio-Rad Laboratories, Hercules, CA, USA). The mean \pm SD of arbitrary density units was calculated from at least duplicate blots.

\section{Statistical analysis}

Statistical analyses were performed with Statgraphics plus (v 5.0) (Statpoint Technologies Inc., Warrenton, VA, USA) and SPSS (v 18) (IBM, New York, NY, USA) softwares. $p<0.05$ was defined as a threshold for significant changes.

\section{Results and discussion}

The gene expression profiles of several tissues subjected to experimental oxidative stress (OS) have been studied by other authors using microarray analysis in model organisms such as Drosophila and mouse. In the nervous system, several brain regions showing selective vulnerability to OS, such as hippocampus, substantia nigra and striatum, have been studied (Chung et al. 2005; Wang et al. 2007; Chin et al. 2008). However, the transcript profile of the OSchallenged cerebellum, home of a massive number of OSsensitive granule cells (Gonzalez-Polo et al. 2004; Wang et al. 2009), has not been experimentally assessed.

Besides, ApoD is consistently expressed in the rodent cerebellum, mainly in oligodendrocytes and astrocytes (Provost et al. 1991; Ong et al. 1999; Navarro et al. 2004; Ganfornina et al. 2005), and the ApoD-KO mouse shows behavioral defects in cerebellar-related motor coordination (Ganfornina et al. 2008).

Therefore, we selected the cerebellum to assay the effect of altering the expression of $A p o D$ on the early response to an acute experimental OS produced by a single dose of PQ. At the time point selected, $6 \mathrm{~h}$ after PQ exposure, ApoD transcript up-regulation has taken place and elevated levels of ApoD protein are present in the tissue, but neither brain lipid peroxidation nor neuronal cell death have yet increased over the basal levels (McCormack et al. 2005; Prasad et al. 2007; Ganfornina et al. 2008). Using this protocol we expect to isolate the direct transcriptional response to PQ from responses derived as secondary consequences of cell death occurring in the tissue, or other slow-paced cellular events that are also modified by $A p o D$, like lipid peroxidation. Therefore, only transcriptional changes underlying functional responses of neurons and glia are expected, and their dependence on $A p o D$ function can be discerned.

\section{Quality controls and validation of microarray results}

The quality of hybridization signals in our arrays was assessed according to standard Affymetrix guidelines. The percent of present (P) vs. absent (A) calls (average $\mathrm{P}: 64.1 \pm 2.3 \%)$ is in the accepted range, as it is also the number of concordant calls in the triplicates, that averages $87.3 \pm 2.1 \%$. The reliability index (the Cronbach's $\alpha$ coefficient estimated from multiple regression analysis) of the triplicate hybridization values averages $0.99 \pm 0.01$ and indicates an adequate level of reproducibility (Table S1).

\section{Differential gene expression upon constitutive loss-of- function and over-expression of $A p o D$}

Our first inquiry was to assay the effects on transcription because of the constitutive absence of $A p o D$ in the cerebellum of young adult mice. Twenty eight genes passed our selection criteria (adjusted $p$-value $<0.05$ after FDR correction, and a $\mathrm{FC} \geq \pm 2$ threshold) for robust changes in expression in the ApoD-KO mice under control conditions (Fig. 1a; Table S3). In this set, $70 \%$ of the genes are down-regulated. The fact that $A p o D$ is the gene most down-regulated in the ApoD-KO samples (arrow in Fig. 1a) was an expected outcome and supports the array results. Despite the reduced number of differentially expressed genes obtained, a significant enrichment occurs in Gene Ontology (GO) terms related to transcriptional regulation and to neuron excitability (Fig. 1b; Table S9).

Several genes related to the transmission of neuronal action potentials appear down-regulated in the ApoD-KO neural tissue. One of them is $M b p$, a myelin-associated protein that contributes to the formation of compact myelin (Simons and Trotter 2007) and thus improves axonal conduction velocity. We have found a similar down-regulation of $M b p$ in ApoD-KO peripheral nerves (Ganfornina et al. 2010), stressing the link between $A p o D$ and the myelination process. Also, the modulation of synaptic transmission and neuronal firing patterns by $\mathrm{Ca}^{2+}$-activated $\mathrm{K}^{+}$channels is expected to be altered as the Kcnmal gene (Salkoff et al. 2006) is down-regulated in ApoD-KO mice. In relation to neurotransmission as well, the synaptic machinery appears to react with an increased transcription of ionotropic glutamate receptor GluR4 [ $\alpha$-amino-3-hydroxy-5-methylisoxazole-4-propionate (AMPA) receptors] and the neurotransmitter vesicle-related genes $(K f 1 b$ and $V a p b)$ to increase a possibly reduced synaptic efficacy in ApoD-KO brain. In relation to this, we have reported a significant decrease of functional glutamate receptors in the brain of ApoD-KO mice (Boer et al. 2009) that could cause a compensatory transcriptional up-regulation of some glutamate receptors.

Another interesting link is the implication of the anterograde transport motor protein Kiflb in the myelination process by properly localizing $M b p$ mRNA (Lyons et al. 2009). The down-regulation of $M b p$ mRNA and a compensatory up-regulation of $K f 1 b$ are pointing to a role for $A p o D$ in the process of myelination in the CNS, as has been proposed for the PNS (Ganfornina et al. 2010). A qRT-PCR study of an independent sample of mice equally shows lower 


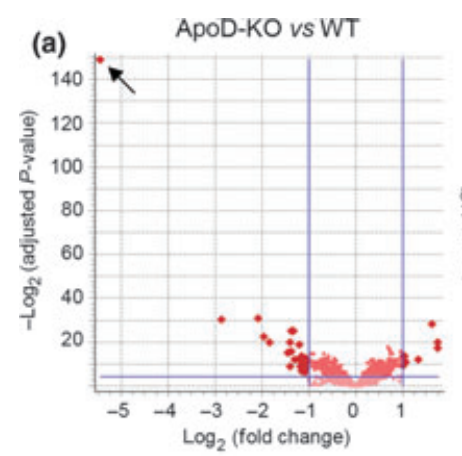

(c)
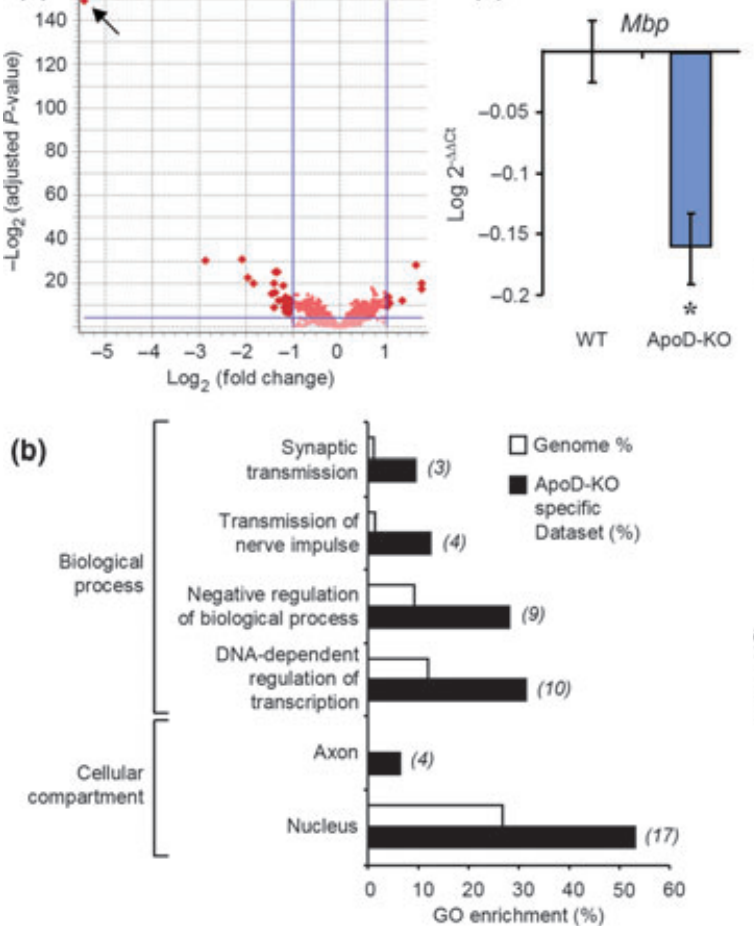

Fig. 1 Transcriptional profile of the ApoD-KO cerebellum in adult mice in control conditions. (a) Volcano plot showing the relationship between $p$-value and $\log _{2}$ (fold change) for genes differentially expressed in the ApoD-KO compared to the WT tissue. The statistically significant genes ( $F C \geq 2$; FDR-adjusted $p$-value $<0.05$ ) are pointed by dark red dots. Arrow marks the down-regulation of $A p o D$. (b) Gene ontology terms significantly enriched in genes differentially expressed in ApoD$\mathrm{KO}$ cerebellum. The number of genes in the experimental dataset is

transcription levels of $M b p$ in the diencephalon of ApoD-KO mice (Fig. 1c), and immunoblot analysis of WT and ApoD-KO whole brains confirms that lower amounts of Mbp protein (Fig. 1d) is a general effect of $A p o D$ loss.

A different set of $A p o D$-dependent genes, such as the Map3K7, the nuclear factor Nfla and the chemokine Ccl21 are related to stress responses. The absence of ApoD up-regulates Map3k7, a kinase involved in cell responses to environmental stresses through activation of c-Jun $\mathrm{N}$ terminal kinase (MAPK8/JNK) and mitogen-activated protein kinase kinase 4 (MAP2K4/MKK4) signaling cascades. Map3k7 is activated by arachidonic acid, a candidate physiological ligand for ApoD (Vogt and Skerra 2001). Nfia, also up-regulated in the ApoD-KO, regulates the expression of stress-response glial proteins such as glial fibrillary acidic protein (GFAP) (Gopalan et al. 2006). Finally, the chemokine $\mathrm{Ccl} 21$, involved in the neuronal response to ischemia (de Jong et al. 2005), is down-regulated in the ApoD-KO mice. We confirmed that transcriptional levels of Ccl21 and Nfia also show similar differences in the ApoD-KO cerebellum when studied by qRT-PCR (Fig. 1e). (d)

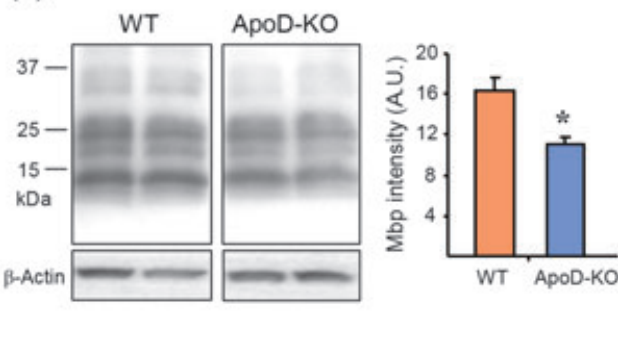

(e)

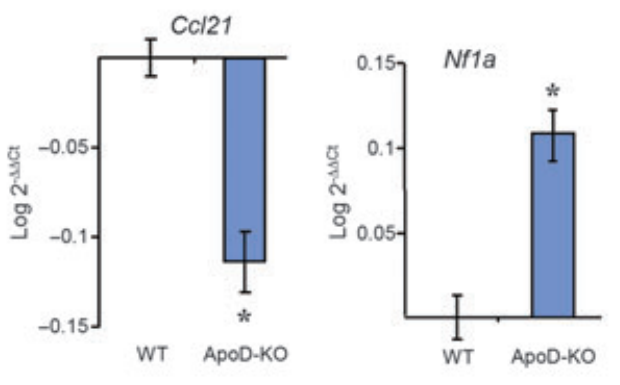

shown in italics. (c) qRT-PCR analysis of Mbp expression in the diencephalon (WT tissue is used as the calibrator sample). (d) Immunoblot analysis of Mbp protein expression in WT and ApoD-KO brains. Protein levels were quantified by band densitometry normalized to $\beta$-actin signal. (e) qRT-PCR analysis of the expression of the Ccl21 and Nf1a genes in the cerebellum. Statistical differences assayed by unpaired Student's $t$-test in (d) and by Mann-Whitney $U$-test in $(c, e) .{ }^{*} p<0.05$.

Our second query was to assay the effects on transcription of over-expressing hApoD in neurons. The microarray analysis for the hApoD-Tg mice revealed a substantial number of genes (388) with significant changes in expression levels in the cerebellum (Fig. 2a). The pool of genes fulfilling our criteria for selection (adjusted $p$-values $<0.05$ after FDR correction, and FC $\geq \pm 2$ ) are shown in Table S4. In terms of enrichment of GO terms (Table S10, Fig. 2b), hApoD-Tg mice show significant changes in hormone receptor binding, transporter activity for neurotransmitters, phospholipid metabolism and response to metabolic stimuli. An interesting observation is the numerous up-regulated genes evidenced in the hApoD-Tg cerebellum related to vesicle dynamics in axonal and synaptic function (synaptotagmins I,II,XIII; syntaxin 6; rabphilin 3A; kinesins Ia, Va,Vc; dynein light chain, $\alpha$ synuclein, dynamin 2), possibly related to the ectopic secretion in neurons of hApoD itself and the subsequent secretory vesicle load. These changes could in turn affect synaptic functions.

In order to test whether the transcriptome of a particular NS cell type is modified by the $A p o D$ genotype, we 

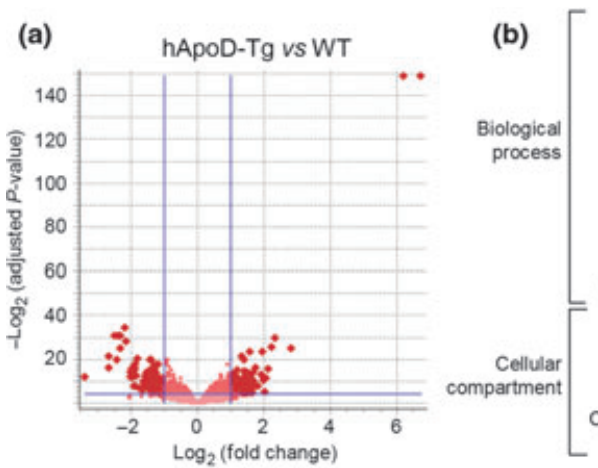
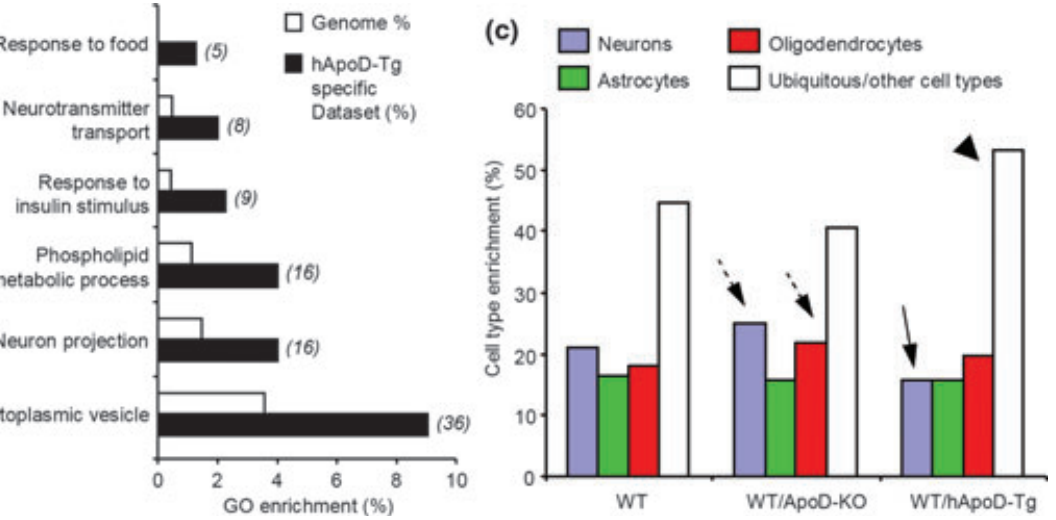

Fig. 2 Effects of hApoD over-expression in cerebellar gene expression ( $a$ and $b$ ) and modifications in cell-type enrichment distributions in the ApoD-dependent gene pools (c). (a) Volcano plot for genes differentially expressed in the hApoD-Tg compared to the WT tissue in control conditions. Genes statistically significant (FC $\geq 2$; FDRadjusted $p$-value $<0.05$ ) are shown by dark red dots. (b) GO terms enrichment analysis of the gene set obtained in (a). The number of genes in the experimental dataset is shown in italics. (c) Cell type enrichment analysis for the genes differentially expressed in ApoD-KO and $\mathrm{hApoD}-\mathrm{Tg}$ cerebellum compared to the cell type representation in the WT mouse brain (Cahoy et al. 2008). compared our lists of genes with those reported by Cahoy et al. (2008) to be enriched in different cell types of the mouse brain. Under control conditions, the genes differentially regulated in the cerebellum of ApoD-KO mice are distributed in a cell type pattern similar to that of WT brain. Only a moderate increase in the representation of neuronal and oligodendroglial genes is apparent (dashed arrows, Fig. 2c) at the expense of ubiquitous genes, whereas astrocyte genes are equally abundant. However, the hApoD-Tg cerebellar arrays show a marked decrease in the transcription of neuron-specific genes (arrow, Fig. 2c) accompanied by an increase in ubiquitous genes (possibly those with housekeeping functions; arrowhead in Fig. 2c). This might reflect the response of neurons to the ectopic expression of hApoD.

In summary, both a constitutive absence of ApoD expression and an over-expression of ApoD in mouse neurons result in transcriptional changes in the adult mouse cerebellum of genes related to neuronal function, mainly affecting action potential conduction and synaptic function, as well as genes related to myelin management. Moreover, several genes that control the cellular response to environmental stimuli appear regulated by $A p o D$ expression, suggesting that ApoD-KO brains are suffering from constitutive stress such as OS or inflammation. This result is supported by their elevated basal levels of lipid peroxides (Ganfornina et al. 2008) and is in agreement with our findings in the PNS, where the transcriptional profile of injury-regulated genes in the intact ApoD-KO nerves resembles the profile of a damaged WT sciatic nerve (Ganfornina et al. 2010). Appropriate levels of $A p o D$ are thus essential for a proper nervous system homeostasis.
Comparative gene expression profile analysis of wild type cerebellar tissue exposed to experimental oxidative stress To identify gene networks participating in the early cellular response of the cerebellum to OS, we studied the gene expression changes in WT samples $6 \mathrm{~h}$ after PQ treatment.

We found 118 genes that showed regulation in the WT cerebellum by the experimental treatment, most of them (71\%) presenting up-regulations (Fig. 3a). Table S5 lists only the genes with $\mathrm{FC} \geq \pm 3$. The GO analysis identifies gene functional groups related to the cellular response to OS, the regulation of cell death and proliferation, and the regulation of transcription (Fig. 3d). It is also apparent the enrichment in cytosolic and extracellularly secreted proteins. Furthermore, genes related to kinase signaling pathways, critically involved in the cell response to OS, are also enriched in this dataset.

To corroborate our results, as well as to detect potentially important genes common to the response to OS in different tissues, we performed a meta-analysis of microarray studies that explored transcriptional changes upon OS (Edwards et al. 2004; Tomita et al. 2006, 2007; Wang et al. 2007, 2009; Chin et al. 2008; Olesen et al. 2008; Patel et al. 2008; Sforza 2008) using the LOLA database and analysis software (http://lola.gwu.edu/) (Cahan et al. 2005).

Thirty genes that appear differentially expressed in our analysis of the WT cerebellum upon PQ treatment (some of them highlighted in bold in Tables S5 and S6) showed concordant regulations in other microarray reports (see above) using diverse OS experimental paradigms. It is important to mention that genes such as Fkbp5, Zfp36, Ctgf, Sgk3, Cebpd, Gadd45g, Nr4a1, S3-12, Cdknla, Pdk4, Mt2 and Map3k6, present in our PQ-regulated dataset, have been reported as early response genes to PQ treatment in other 

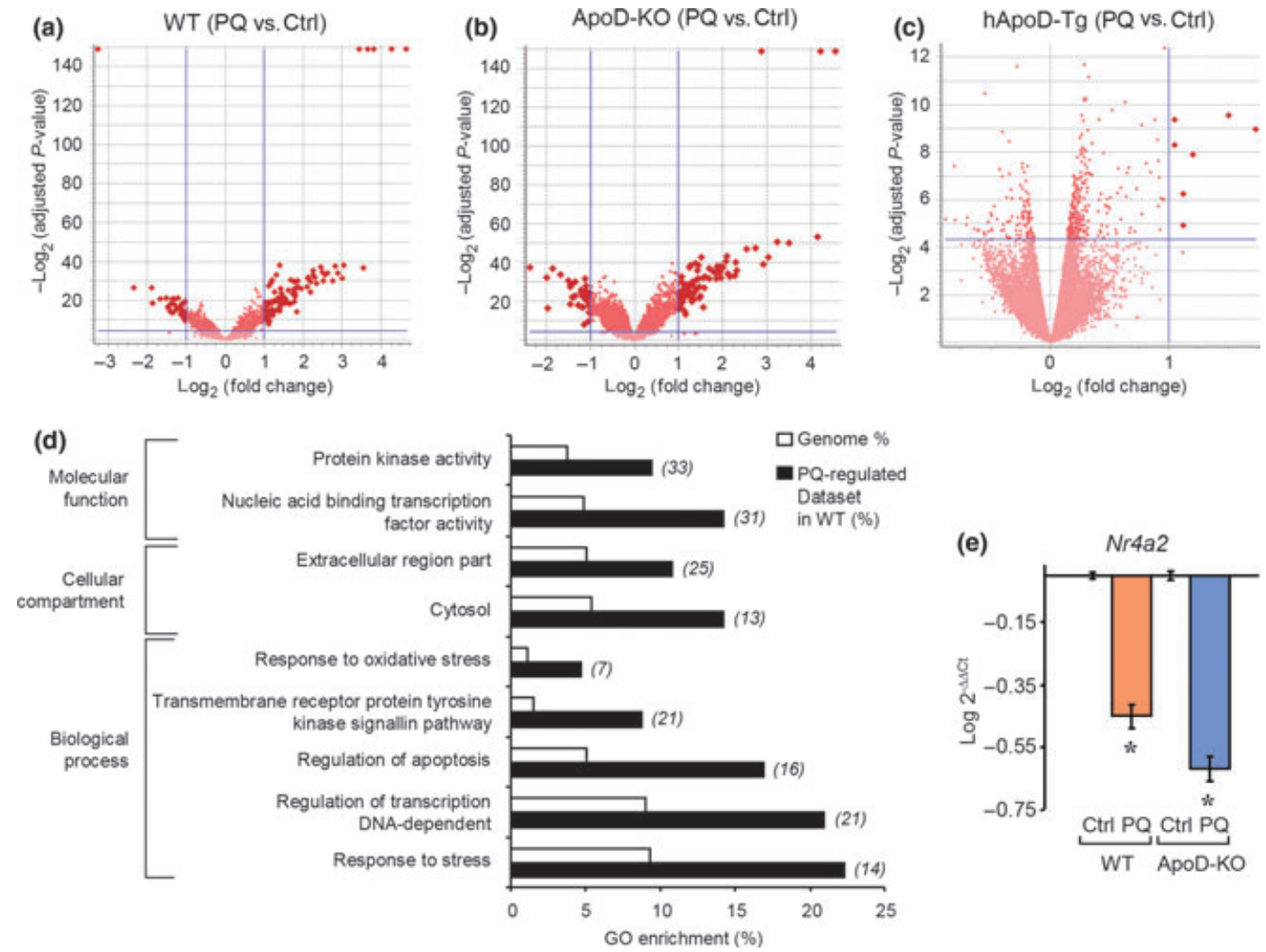

Fig. 3 Transcriptome profile of oxidative stress-challenged cerebellum. (a-c) Volcano plots for the genes constituting the early response to a single dose of $P Q$ in WT (a), ApoD-KO (b) and hApoD-Tg (c) cerebellum. (d) Enrichment plot of $\mathrm{GO}$ terms for the PQ-challenged WT tissue. The number of genes in the experimental dataset is shown in italics. (e) qRT-PCR confirmation of the PQ-dependent expression of Nr4a2 in WT and ApoD-KO samples using the untreated control samples as calibrators. Statistical differences assayed by MannWhitney U-test in (e). ${ }^{*} p<0.05$.

represents $61 \%$ of the genes that organize the early response to PQ in the WT (see above).

We randomly selected a gene moderately regulated by PQ treatment that, in addition, showed slight differences in expression in WT and ApoD-KO cerebellum, so that we can test whether small expression differences detected in the array are validated by an independent quantification method. The Nuclear receptor subfamily 4, group A, member 2 (Nr4a2), involved in dopaminergic neurons development and function (Maguire-Zeiss and Federoff 2010) appears downregulated by $\mathrm{PQ}$ in both the WT and ApoD-KO cerebellum (-3.22 FC in WT; $-3.91 \mathrm{FC}$ in ApoD-KO). Comparable down-regulations (-2.81 FC in WT; $-4.15 \mathrm{FC}$ in ApoD-KO) were obtained by qRT-PCR experiments using the same RNA samples used for the arrays (Fig. 3e).

Next, we analyzed the genes showing a differential response to PQ in WT and ApoD-KO cerebellum. Seventy seven genes showed ApoD-dependent changes in their transcriptional levels (Tables S6 and S7, and Fig. 4b). Thirty one transcripts change their expression specifically in ApoD$\mathrm{KO}$ cerebellum (Table S7), and can thus be considered genes that respond to the OS generated by PQ only when $A p o D$ is 
(a)

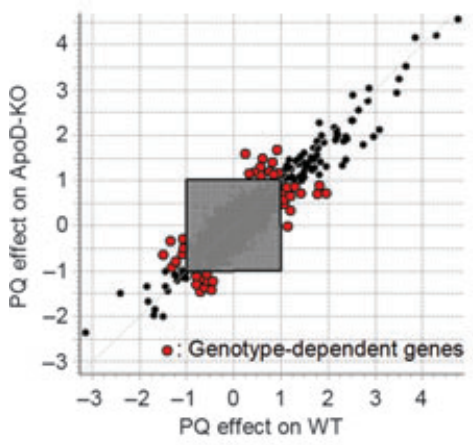

(b)

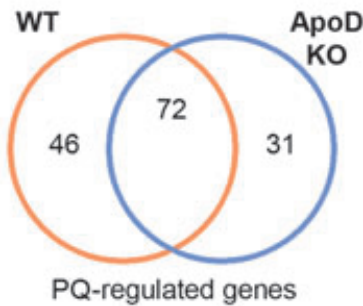

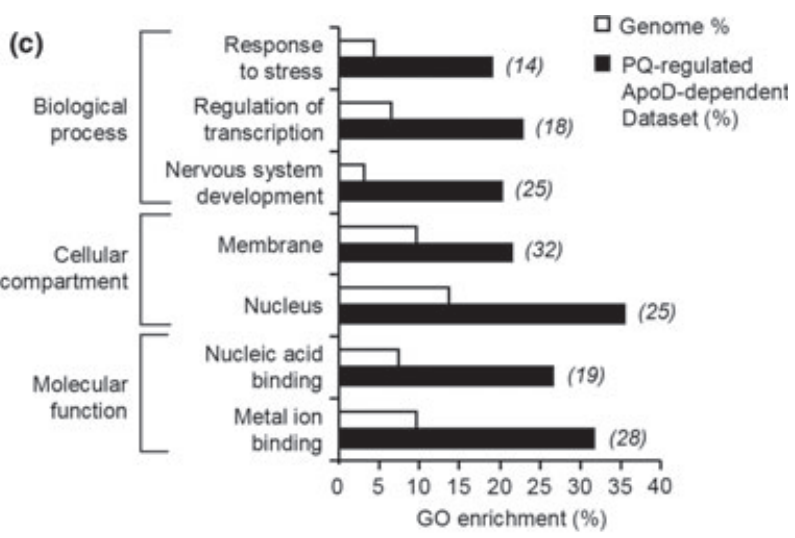

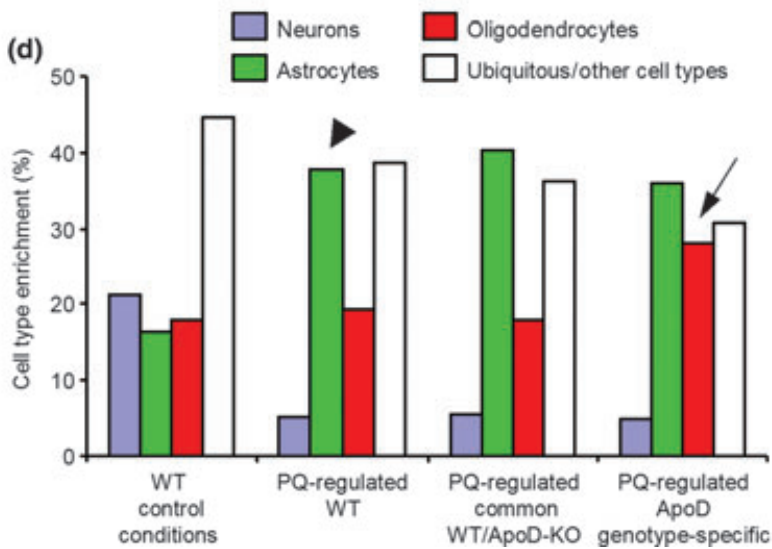

Fig. 4 Early transcriptional response to $P Q$ in the ApoD-KO cerebellum. (a) Correlation plot of genes differentially expressed upon $\mathrm{PQ}$ treatment in WT and ApoD-KO mice. The gray box marks the boundaries for non-statistically significant changes. Red dots point to genes that show genotype-dependent regulation by $P Q$. Black dots are genes equally regulated in WT and ApoD-KO mice. (b) Venn diagram of $\mathrm{PQ}$-regulated genes in WT and ApoD-KO

not being expressed by cerebellar astrocytes and oligodendrocytes. In contrast, 46 transcripts were specifically regulated in WT, i.e., they are genes that require the presence of ApoD to respond to OS (Table S6).

The GO analysis of the 77 genes (46 WT specific and 31 ApoD-KO specific) differentially regulated by $\mathrm{PQ}$ in a genotype-dependent manner, uncovers a significant enrichment in terms related to the regulation of transcription, nervous system development, and the response to stress (Fig. 4c). Similarly, an enriched set of these genotypedependent genes code for membrane-related proteins, which suggests a role of $A p o D$ in the effect of OS on cell membranes.

In addition to the genes that show all-or-none $A p o D$ dependent responses, there are others, among the 72 common genes (intersection in Fig. 4b), that differ in the magnitude of the response to $\mathrm{PQ}$. Our analysis identifies five genes with $|\mathrm{FC}(\mathrm{KO})-\mathrm{FC}(\mathrm{WT})| \geq 1.5$ in their response to $\mathrm{PQ}$. The genes Rhoj, Cdknla, Polr3e and Pdk4 are found more cerebella. (c) Plot showing the enrichment in GO terms of PQregulated genes that are dependent on $A p O D$ genotype. The number of genes in the experimental dataset is shown in italics. (d) Cell type enrichment analysis in $P Q$-regulated genes, grouped according to their dependence on $A p o D$ genotype and compared to the cell type representation in the WT mouse brain (Cahoy et al. 2008).

up-regulated in ApoD-KO, and Fos is less down-regulated in ApoD-KO. Interestingly, three of these genes are part of the common pool of early-responders to OS that we have uncovered in our meta-analysis (bold type in Table S5).

Finally, we studied the cell type enrichment patterns of the groups of genes that respond to PQ in WT and ApoD-KO cerebellum (Fig. 4d). In these comparisons, the most obvious result is the enrichment of astrocyte-specific genes and the under-representation of neuronal genes (Fig. 4d, arrowhead) in the WT response to PQ. This is consistent with the known critical role of astrocytes in the OS-challenged brain (Rossi and Volterra 2009). A similar pattern is found for the common genes equally regulated by PQ in both WT and ApoD-KO cerebellum. However, superimposed to this common pattern in the response to $\mathrm{PQ}$, the pool of genes that specifically respond to PQ either in the WT or in the KO show a marked increase in oligodendrocyte-specific genes at the expense of ubiquitous genes (arrow in Fig. 4d).This result supports our hypothesis that the absence of ApoD 


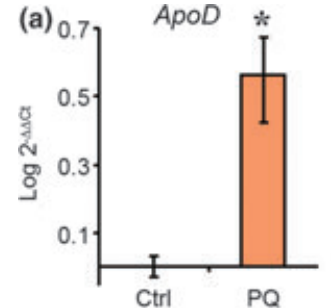

(b)

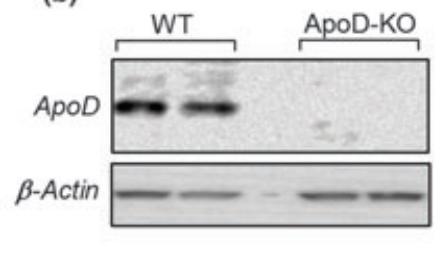

(c)
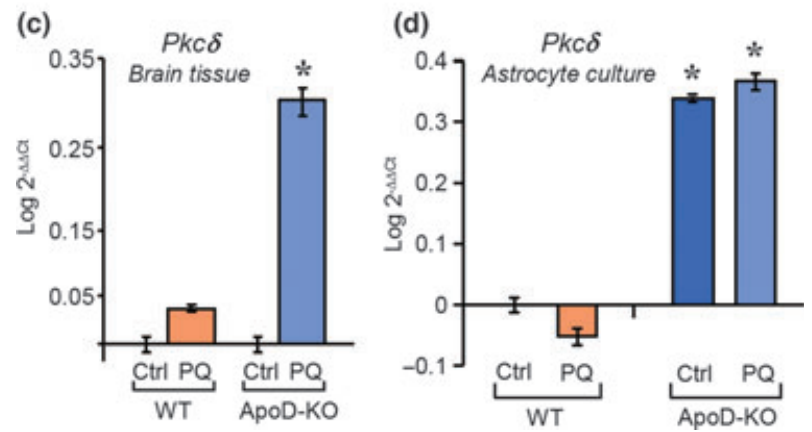

Fig. 5 Glial genes involved in the oxidative stress response of cerebellum. (a) qRT-PCR measuring the expression of $A p o D$ in the diencephalon of ApoD-KO mice chronically exposed to oxidative stress by $P Q$ treatment. (b) Immunoblot analysis of $A p o D$ in the same samples of WT and ApoD-KO mice analyzed in (a), showing the absence of ApoD translation in ApoD-KO mice. (c) PQ-dependent expression of the gene $P k c \delta$ in WT and ApoD-KO cerebellum. Control untreated samples were used as calibrators. (d) $P k c \delta$ gene expression in cultured primary astrocytes exposed to $\mathrm{PQ}$-generated oxidative stress for $6 \mathrm{~h}$. A significant basal up-regulation is observed in the ApoD-KO cultures, but no additional over-expression is triggered by $P Q$. Statistical differences assayed by Mann-Whitney $U$-test in (e). ${ }^{*} p<0.05$.

makes lipid-bearing cell compartments more susceptible to oxidative stress (Sanchez et al. 2006; Ganfornina et al. 2008). We can predict from this pattern that $A p o D$ function is important for oligodendrocytes, with their lipid-enriched myelin, especially in pro-oxidant situations. Among the genes that would normally respond to the OS in oligodendrocytes, they must either need $A p o D$ to respond or their response is inhibited by $A p o D$.

A second set of comparisons was performed of the genes regulated by PQ-treatment in WT and hApoD-Tg cerebellum. Surprisingly, only six hApoD-Tg genes appear regulated by PQ (Table S8). Three of them are well known OS-regulated genes $(S 3-12, F k b p 5$ and $X d h)$, but their FC are well below the levels attained in the WT tissue (see Table S5 for comparison). Other genes with expression levels related to brain pathologies (Ttr, Folr1 and Sdc4) appear up-regulated in the brain of PQ-challenged hApoD-Tg mice. The lack of an early gene regulation in response to OS when $A p o D$ is over-expressed in the brain further confirms the improved survival and the prevention of lipid peroxide brain accumulation previously reported (Ganfornina et al. 2008).

In view of our GO and cell-type enrichment analyses, two main biological processes appear as clearly dependent on the function of $A p o D$ in OS conditions: myelin management and glial responses to stress.

Among the genes whose response to PQ is genotypedependent, a significant number (Aspal, Tnc, Cldn5, Cdh11, Elovl7, Eomes, Sox4, Sox10, Tyro3 and Ugt8a) are related to the myelination process in the CNS. Seven of these genes are down-regulated by PQ, but they belong to the WT-specific group, meaning that their OS-induced inhibition is absent in the ApoD-KO cerebellum. These genes are normally shut down upon OS, and are thus halting myelin synthesis when OS affects oligodendrocytes. The anomalous maintenance of their expression in the absence of ApoD might potentially enhance the already high vulnerability of oligodendrocytes. This effect can in turn be aggravated by the ApoD-KO specific down-regulation of genes such as Aspal and Tnc that is correlated with demyelination processes (Zhao et al. 2009; Mattan et al. 2010).

The cellular response to OS, and particularly the astroglial and microglial responses, is especially relevant to our proposal that $A p o D$ is involved in the detoxification system against OS. A group of 18 genes (highlighted in italics in Tables S6 and S7) are related to such glial responses.

One of these OS-responsive genes is ApoD itself. We observed an up-regulation of ApoD mRNA in response to PQ in the ApoD-KO cerebellum (see Table S7). Although ApoD expression is up-regulated by OS (Ganfornina et al. 2008), this result is a priori unexpected in the ApoD-KO background. We confirmed by qRT-PCR that an increased amount of $A p o D$ mRNA also exists in a different sample of WT and ApoD-KO brains a week after a chronic treatment with PQ (Fig. 5a). However, we already reported that a truncated mRNA species is produced in the ApoD-KO brain (Ganfornina et al. 2008), and a lack of translation was clear by immunoblot (Fig. 5b). Interestingly, no transcriptional regulation of mouse $A p o D$ was observed in the PQ-treated hApoD-Tg tissue (Table S4). These results support that $A p o D$ is required in the normal cell response to OS, and that the mechanisms regulating $A p o D$ gene transcription, normally part of an early response, can persist chronically under conditions of null protein expression.

A set of genes among those specifically down-regulated upon PQ in ApoD-KO cerebellum, Cd44, Phlda1 and Efnb2, are also related to the molecular pathways of OS-responding genes. These genes are known to be abundantly transcribed in the OS-resistant mesencephalic A10 dopaminergic neurons (Chung et al. 2005). A10 neurons also produce high amounts of several neuropeptides, such as pituitary adenylate cyclase-activating polypeptide (PACAP), that confer resistance to MPTP-associated OS (Chung et al. 2005). Interestingly, ApoD has been recently found to induce pituitary adenylate cyclase-activating polypeptide (PACAP) expression from neuronal primary cultures (Kosacka et al. 2011). Together with our findings, these data suggest that ApoD must be required, at least in the less labile sets of 
dopaminergic neurons, to keep appropriate levels of protectors under OS conditions.

Finally, an interesting gene specifically up-regulated in PQ-challenged ApoD-KO cerebellar arrays is Protein kinase $C \delta(P k c \delta)$. Its up-regulation is further confirmed in the same samples by qRT-PCR (Fig. 5c). Although expressed ubiquitously and involved in a wide range of cellular functions, $P k c \delta$ is among the genes significantly enriched in astrocytes in the Cahoy et al. (2008) analysis. Also, it has been recently linked to the PQ-induced OS generation and the astroglial response in the nervous system (Kim et al. 2008). Given the major role of astrocytes in the PQ response, their expression of $A p o D$ upon stressful situations, and the specific vulnerability of ApoD-KO astrocytes to PQ-generated OS (our unpublished results; Bajo-Grañeras et al.) we tested by qRT-PCR the transcription of $P k c \delta$ in astrocyte-enriched primary glial cultures of WT and ApoD-KO mice upon $6 \mathrm{~h}$ of PQ treatment. This acute PQ treatment produced, however, no significant regulation of $P k c \delta$ in astrocyte cultures of either genotype (Fig. 5d), suggesting that the specific early upregulation of $P k c \delta$ we observe in the PQ-treated ApoD-KO cerebellum could occur in microglial cells, which are also known to express high levels of $P k c \delta$. In microglia, $P k c \delta$ is in fact linked to PQ-dependent reactive oxygen species (ROS) production mediated by activation of NADPH oxidase (Miller et al. 2007). On the other hand, in basal conditions a significant increase in the levels of $P k c \delta$ expression is seen in ApoD-KO astrocytes (Fig. 5d), supporting the enhanced vulnerability of the ApoD-KO nervous system to either physiological or pathologically generated OS.

As glial cells are also implicated in the priming effects that occur in PQ-related neurodegeneration, and this process is dependent on signals exchanged among microglia, astrocytes and neurons (Purisai et al. 2007; Klintworth et al. 2009), studying the role of $A p o D$ in neuron-glia and glia-glia interactions is of paramount importance, and is the logical next step in our research program aiming to understand the role of this lipocalin in nervous system development and function.

In summary, the altered expression profiles in the ApoD$\mathrm{KO}$ cerebellum, both in control conditions and after PQ treatment, along with the deficient transcriptional response to PQ observed in the hApoD-Tg tissue, strongly support that the presence of $A p o D$ in the neural environment is necessary for a proper protection against oxidative damage.

\section{Acknowledgements}

We thank J.R. Acebes, E. González and E. Martín for technical assistance, and the Lazarillo Lab (M. Ruiz, N. García-Mateo, M. del Caño \& A. Pérez-Castellanos) for their helpful discussions and positive criticisms. We thank S. Sanz for help with some of the qRTPCR experiments. Thanks also to Dr. E. Fermiñan (Genomics facility at the Centro de Investigacion del Cancer) for performing the array hybridizations. This work was supported by grant CIHR MOP
15677 to E.R.; FRSQ and CRSNG studentships to S.D.C.; grants BFU2007-61848 (DGICYT) and CIBER CB06/06/0050 (FISSICiii) to C.G.; and grants MEC BFU2005-00522, JCyL VA049A05, and MICINN BFU2008-01170 to M.D.G. and D.S. Authors declare that no conflict of interest exists in relation to the content of this manuscript. Neither the author's institutions nor the funding agencies had a role in the study design, data collection and analysis, decision to publish, or preparation of the manuscript.

\section{Supporting information}

Additional supporting information may be found in the online version of this article:

Table S1. Parameters used to evaluate the quality of the microarray hybridization signals.

Table S2. Oligonucleotide primers used for qRT-PCR.

Table S3. Genes differentially expressed in ApoD-KO cerebellum in control conditions (Fold change $\geq \pm 2$ ).

Table S4. Genes differentially expressed in hApoD-Tg cerebellum in control conditions (Fold change $\geq \pm 2$ ).

Table S5. PQ-regulated genes in WT cerebellum (Fold change $\geq$ $\pm 2)$.

Table S6. PQ-regulated genes specific for WT (Fold change $\geq$ $\pm 2)$.

Table S7. PQ-regulated genes specific for ApoD-KO (Fold change $\geq \pm 2$ ).

Table S8. PQ-regulated genes specific for hApoD-Tg (Fold change $\geq \pm 2$ ).

Table S9. GO Terms enriched in ApoD-KO vs. WT comparison.

Table S10. GO Terms enriched in hApoD-Tg vs. WT comparison.

Table S11. GO terms enrichment in WT PQ-regulated genes.

Table S12. GO terms enrichment in genotype-dependent PQregulated genes.

As a service to our authors and readers, this journal provides supporting information supplied by the authors. Such materials are peer-reviewed and may be re-organized for online delivery, but are not copy-edited or typeset. Technical support issues arising from supporting information (other than missing files) should be addressed to the authors.

\section{References}

Apps R. and Garwicz M. (2005) Anatomical and physiological foundations of cerebellar information processing. Nat. Rev. Neurosci. 6, 297-311.

Baldi P. and Long A. D. (2001) A Bayesian framework for the analysis of microarray expression data: regularized $\mathrm{t}$-test and statistical inferences of gene changes. Bioinformatics 17, 509-519.

Blazejczyk M., Miron M. and Nadon R. (2007) FlexArray: A Statistical Data Analysis Software for Gene Expression Microarrays. Genome Quebec, Montreal, Canada.

Boer S., Sanchez D., Reinieren I., van den Boom T., Udawela M., Scarr E., Ganfornina M. D. and Dean B. (2009) Decreased kainate receptors in the hippocampus of apolipoprotein D knockout mice. Prog. Neuropsychopharmacol. Biol. Psychiatry 34, 271-278.

Cahan P., Ahmad A. M., Burke H. et al. (2005) List of lists-annotated (LOLA): a database for annotation and comparison of published microarray gene lists. Gene 360, 78-82. 
Cahoy J. D., Emery B., Kaushal A. et al. (2008) A transcriptome database for astrocytes, neurons, and oligodendrocytes: a new resource for understanding brain development and function. J. Neurosci. 28, 264-278.

Chin M. H., Qian W. J., Wang H. et al. (2008) Mitochondrial dysfunction, oxidative stress, and apoptosis revealed by proteomic and transcriptomic analyses of the striata in two mouse models of Parkinson's disease. J. Proteome Res. 7, 666-677.

Chung C. Y., Seo H., Sonntag K. C., Brooks A., Lin L. and Isacson O. (2005) Cell type-specific gene expression of midbrain dopaminergic neurons reveals molecules involved in their vulnerability and protection. Hum. Mol. Genet. 14, 1709-1725.

Do Carmo S., Fournier D., Mounier C. and Rassart E. (2009) Human apolipoprotein $\mathrm{D}$ overexpression in transgenic mice induces insulin resistance and alters lipid metabolism. Am. J. Physiol. Endocrinol. Metab. 296, E802-E811.

Drechsel D. A. and Patel M. (2008) Role of reactive oxygen species in the neurotoxicity of environmental agents implicated in Parkinson's disease. Free Radic. Biol. Med. 44, 1873-1886.

Edwards M. G., Sarkar D., Klopp R., Morrow J. D., Weindruch R. and Prolla T. A. (2004) Impairment of the transcriptional responses to oxidative stress in the heart of aged C57BL/6 mice. Ann. N Y Acad. Sci. 1019, 85-95.

Ganfornina M. D., Sanchez D., Pagano A., Tonachini L., DescalziCancedda F. and Martinez S. (2005) Molecular characterization and developmental expression pattern of the chicken apolipoprotein D gene: implications for the evolution of vertebrate lipocalins. Dev. Dyn. 232, 191-199.

Ganfornina M. D., Do Carmo S., Lora J. M. et al. (2008) Apolipoprotein $\mathrm{D}$ is involved in the mechanisms regulating protection from oxidative stress. Aging Cell 7, 506-515.

Ganfornina M. D., Do Carmo S., Martinez E., Tolivia J., Navarro A., Rassart E. and Sanchez D. (2010) ApoD, a glia-derived apolipoprotein, is required for peripheral nerve functional integrity and a timely response to injury. Glia 58, 1320-1334.

Gonzalez-Polo R. A., Rodriguez-Martin A., Moran J. M., Niso M., Soler G. and Fuentes J. M. (2004) Paraquat-induced apoptotic cell death in cerebellar granule cells. Brain Res. 1011, 170-176.

Gopalan S. M., Wilczynska K. M., Konik B. S., Bryan L. and Kordula T. (2006) Nuclear factor-1-X regulates astrocyte-specific expression of the alpha1-antichymotrypsin and glial fibrillary acidic protein genes. J. Biol. Chem. 281, 13126-13133.

Huang da W., Sherman B. T. and Lempicki R. A. (2009) Systematic and integrative analysis of large gene lists using DAVID bioinformatics resources. Nat. Protoc. 4, 44-57.

Hull-Thompson J., Muffat J., Sanchez D., Walker D. W., Benzer S., Ganfornina M. D. and Jasper H. (2009) Control of metabolic homeostasis by stress signaling is mediated by the lipocalin NLaz. PLoS Genet. 5, e1000460.

de Jong E. K., Dijkstra I. M., Hensens M., Brouwer N., van Amerongen M., Liem R. S., Boddeke H. W. and Biber K. (2005) Vesiclemediated transport and release of CCL21 in endangered neurons: a possible explanation for microglia activation remote from a primary lesion. J. Neurosci. 25, 7548-7557.

Kim S., Hwang J., Lee W. H., Hwang D. Y. and Suk K. (2008) Role of protein kinase Cdelta in paraquat-induced glial cell death. J. Neurosci. Res. 86, 2062-2070.

Klintworth H., Garden G. and Xia Z. (2009) Rotenone and paraquat do not directly activate microglia or induce inflammatory cytokine release. Neurosci. Lett. 462, 1-5.

Kosacka J., Schroder T., Bechmann I., Kloting N., Nowicki M., Mittag A., Gericke M., Spanel-Borowski K. and Bluher M. (2011) PACAP up-regulates the expression of apolipoprotein D in 3T3-L1 adipocytes. DRG/3T3-L1 co-cultures study. Neurosci. Res. 69, 8-16.
Livak K. J. and Schmittgen T. D. (2001) Analysis of relative gene expression data using real-time quantitative PCR and the 2(-Delta Delta C(T)) Method. Methods 25, 402-408.

Lyons D. A., Naylor S. G., Scholze A. and Talbot W. S. (2009) Kiflb is essential for mRNA localization in oligodendrocytes and development of myelinated axons. Nat. Genet. 41, 854858 .

Maguire-Zeiss K. A. and Federoff H. J. (2010) Future directions for immune modulation in neurodegenerative disorders: focus on Parkinson's disease. J. Neural Transm. 117, 1019-1025.

Mattan N. S., Ghiani C. A., Lloyd M., Matalon R., Bok D., Casaccia P. and de Vellis J. (2010) Aspartoacylase deficiency affects early postnatal development of oligodendrocytes and myelination. Neurobiol. Dis. 40, 432-443.

McCormack A. L., Atienza J. G., Johnston L. C., Andersen J. K., Vu S. and Di Monte D. A. (2005) Role of oxidative stress in paraquatinduced dopaminergic cell degeneration. J. Neurochem. 93, 10301037.

Miller R. L., Sun G. Y. and Sun A. Y. (2007) Cytotoxicity of paraquat in microglial cells: involvement of PKCdelta- and ERK1/2-dependent NADPH oxidase. Brain Res. 1167, 129-139.

Navarro A., Del Valle E. and Tolivia J. (2004) Differential expression of apolipoprotein $\mathrm{d}$ in human astroglial and oligodendroglial cells. J. Histochem. Cytochem. 52, 1031-1036.

Olesen B. T., Clausen J. and Vang O. (2008) Characterization of the transcriptional profile in primary astrocytes after oxidative stress induced by Paraquat. Neurotoxicology 29, 13-21.

Ong W. Y., Lau C. P., Leong S. K., Kumar U., Suresh S. and Patel S. C. (1999) Apolipoprotein D gene expression in the rat brain and light and electron microscopic immunocytochemistry of apolipoprotein $\mathrm{D}$ expression in the cerebellum of neonatal, immature and adult rats. Neuroscience 90, 913-922.

Patel S., Singh K., Singh S. and Singh M. P. (2008) Gene expression profiles of mouse striatum in control and maneb + paraquat-induced Parkinson's disease phenotype: validation of differentially expressed energy metabolizing transcripts. Mol. Biotechnol. 40, 59-68.

Prasad K., Winnik B., Thiruchelvam M. J., Buckley B., Mirochnitchenko O. and Richfield E. K. (2007) Prolonged toxicokinetics and toxicodynamics of paraquat in mouse brain. Environ. Health Perspect. 115, 1448-1453.

Provost P. R., Villeneuve L., Weech P. K., Milne R. W., Marcel Y. L. and Rassart E. (1991) Localization of the major sites of rabbit apolipoprotein $\mathrm{D}$ gene transcription by in situ hybridization. J. Lipid Res. 32, 1959-1970.

Purisai M. G., McCormack A. L., Cumine S., Li J., Isla M. Z. and Di Monte D. A. (2007) Microglial activation as a priming event leading to paraquat-induced dopaminergic cell degeneration. Neurobiol. Dis. 25, 392-400.

Rossi D. and Volterra A. (2009) Astrocytic dysfunction: insights on the role in neurodegeneration. Brain Res. Bull. 80, 224-232.

Salkoff L., Butler A., Ferreira G., Santi C. and Wei A. (2006) Highconductance potassium channels of the SLO family. Nat. Rev. Neurosci. 7, 921-931.

Sanchez D., Lopez-Arias B., Torroja L., Canal I., Wang X., Bastiani M. J. and Ganfornina M. D. (2006) Loss of glial lazarillo, a homolog of apolipoprotein D, reduces lifespan and stress resistance in Drosophila. Curr. Biol. 16, 680-686.

Sforza D. M. (2008) Gene expression changes in multiple brain regions of a mouse MPTP model of Parkinson's disease. Gene Expression Omnibus, Vol. GSE7707. National Center for Biotechnology Information.

Simons M. and Trotter J. (2007) Wrapping it up: the cell biology of myelination. Curr. Opin. Neurobiol. 17, 533-540. 
Tarraga J., Medina I., Carbonell J. et al. (2008) GEPAS, a web-based tool for microarray data analysis and interpretation. Nucleic Acids Res. 36, W308-W314.

Tomita M., Okuyama T., Katsuyama H., Hidaka K., Otsuki T. and Ishikawa T. (2006) Gene expression in rat lungs during early response to paraquat-induced oxidative stress. Int. J. Mol. Med. 17, $37-44$.

Tomita M., Okuyama T., Katsuyama H., Miura Y., Nishimura Y., Hidaka K., Otsuki T. and Ishikawa T. (2007) Mouse model of paraquat-poisoned lungs and its gene expression profile. Toxicology 231, 200-209.

Vogt M. and Skerra A. (2001) Bacterially produced apolipoprotein D binds progesterone and arachidonic acid, but not bilirubin or E-3M2H. J. Mol. Recognit. 14, 79-86.

Wang X., Pal R., Chen X. W., Kumar K. N., Kim O. J. and Michaelis E. K. (2007) Genome-wide transcriptome profiling of region-specific vulnerability to oxidative stress in the hippocampus. Genomics $\mathbf{9 0}$, 201-212.

Wang X., Zaidi A., Pal R., Garrett A. S., Braceras R., Chen X. W., Michaelis M. L. and Michaelis E. K. (2009) Genomic and biochemical approaches in the discovery of mechanisms for selective neuronal vulnerability to oxidative stress. BMC Neurosci. 10, 12.

Yuan J. S., Reed A., Chen F. and Stewart C. N. Jr. (2006) Statistical analysis of real-time PCR data. BMC Bioinformatics 7, 85.

Zhao C., Fancy S. P., Franklin R. J. and ffrench-Constant C. (2009) Up-regulation of oligodendrocyte precursor cell alphaV integrin and its extracellular ligands during central nervous system remyelination. J. Neurosci. Res. 87, 3447-3455.

Zheng Q. and Wang X. J. (2008) GOEAST: a web-based software toolkit for Gene Ontology enrichment analysis. Nucleic Acids Res. 36, W358-W363. 
Table S1. Parameters used to evaluate the quality of the microarray hybridization signals

\begin{tabular}{|l|c|c|r|r|}
\hline \multicolumn{1}{|c|}{ Arrays (3/group) } & Scale factor & Present Calls & Concordant Calls & Reliability index \\
\hline WT-Ctrl & $0.352 \pm 0.05$ & $65.2 \pm 1.29 \%$ & $88.13 \%$ & 0.996 \\
\hline WT-PQ & $0.349 \pm 0.02$ & $64.5 \pm 0.66 \%$ & $88.51 \%$ & 0.997 \\
\hline ApoD KO-Ctrl & $0.358 \pm 0.01$ & $64.2 \pm 0.38 \%$ & $89.16 \%$ & 0.999 \\
\hline ApoD KO-PQ & $0.347 \pm 0.02$ & $61.4 \pm 4.29 \%$ & $82.75 \%$ & 0.997 \\
\hline hApoD Tg-Ctrl & $0.337 \pm 0.05$ & $65.8 \pm 0.81 \%$ & $87.68 \%$ & 0.991 \\
\hline hApoD Tg-PQ & $0.336 \pm 0.04$ & $64.6 \pm 0.62 \%$ & $87.63 \%$ & 0.991 \\
\hline
\end{tabular}


Table S2. Oligonucleotide primers used for qRT-PCR

\begin{tabular}{|c|c|c|}
\hline Gene-primer & Sequence Acc. Number & Oligonucleotide sequence \\
\hline Rpl18-Forward & \multirow[t]{2}{*}{ NM_009077.2 } & 5'-TTCCGTCTTTCCGGACCT \\
\hline Rpl18-Reverse & & 5'- TCGGCTCATGAACAACCTCT \\
\hline ApoD-Forward & \multirow[t]{2}{*}{ NM_007470.2 } & 5'- GAAGCCAAACAGAGCAACG \\
\hline ApoD-Reverse & & 5'- TGTTTCTGGAGGGAGATAAGGA \\
\hline Nr4a2-Forward & \multirow[t]{2}{*}{ NM_013613.2 } & 5'- AGTGCCTAGCTGTTGGGATGGT \\
\hline Nr4a2-Reverse & & 5'- TAGTCAGGGTTTGCCTGGAA \\
\hline Pkcd-Forward & \multirow[t]{2}{*}{ NM_011103.2 } & 5'- CACCAATAGCCGGGACACCATCT \\
\hline Pkcd-Reverse & & 5'- TGGTTGATACCACACAGGTTG \\
\hline Ccl21-Forward & \multirow[t]{2}{*}{ NM_011124.4 } & 5'- AGGCTGGGTGCAGAACCTGAT \\
\hline Ccl21-Reverse & & 5'- TGAAGTTCGTGGGGGATCT \\
\hline Nf1a-Forward & \multirow[t]{2}{*}{ NM_001122952.1 } & 5'- TGGAGGTTGGACCTCGTCATGGT \\
\hline Nf1a-Reverse & & 5'- CTGGCTGGGACTTTCAGATT \\
\hline Mbp-Forward & \multirow[t]{2}{*}{ NM_010777.3 } & 5'- GCTGAGAAGGCCAGTAAGGA \\
\hline Mbp-Reverse & & 5'- CCACGCTTCTCTTCTTTCCA \\
\hline
\end{tabular}


Table S3. Genes differentially expressed in ApoD-KO cerebellum in control conditions (Fold change $\geq+/-2$ )

\begin{tabular}{|c|c|c|c|c|}
\hline UniGene ID & \begin{tabular}{|c|} 
Gene Title \\
\end{tabular} & Gene Symbol & Fold change & $P$ value \\
\hline $\mathrm{Mm} .260456$ & Vesicle-associated membrane protein B and C & Vapb & 3.41 & $4.0 \mathrm{E}-10$ \\
\hline Mm.31274 & Nuclear factor I/A & Nfia & 3.39 & $4.1 \mathrm{E}-09$ \\
\hline Mm.12145 & Retinoblastoma binding protein 4 & Rbbp4 & 3.14 & $5.0 \mathrm{E}-13$ \\
\hline Mm.268548 & Max protein & Max & 2.54 & $5.6 \mathrm{E}-07$ \\
\hline Mm.402393 & Kinesin family member 1B & Kif1b & 2.09 & $1.1 \mathrm{E}-07$ \\
\hline Mm.209263 & Glutamate receptor. ionotropic. AMPA4 (alpha 4) & Gria4 & 2.07 & 3.3E-07 \\
\hline Mm.258589 & Mitogen activated protein kinase kinase kinase 7 & Map3k7 & 2.07 & $8.5 \mathrm{E}-08$ \\
\hline Mm.21841 & Splicing factor. arginine/serine-rich 2 (SC-35) & Sfrs2 & 2.06 & $8.0 \mathrm{E}-06$ \\
\hline Mm.253518 & Bromodomain containing 4 & Brd4 & -2.00 & $1.5 \mathrm{E}-06$ \\
\hline Mm.3360 & Tyr-3/trp-5-monooxygenase activation protein & Ywhaz & -2.07 & $2.6 \mathrm{E}-07$ \\
\hline Mm.5001 & DNA methyltransferase 3A & Dnmt3a & -2.08 & $3.2 \mathrm{E}-05$ \\
\hline Mm.280842 & Heterogeneous nuclear ribonucleoprotein $\mathrm{A} / \mathrm{B}$ & Hnrpab & -2.09 & $4.0 \mathrm{E}-07$ \\
\hline Mm.383196 & Nuclear receptor subfamily 2. group C. member 2 & $\mathrm{Nr} 2 \mathrm{c} 2$ & -2.09 & $1.6 \mathrm{E}-04$ \\
\hline Mm.8687 & CAP. Adenylate cyclase-associated protein 1 (yeast) & Cap1 & -2.20 & $7.6 \mathrm{E}-08$ \\
\hline Mm.3815 & Syndecan 4 & Sdc4 & -2.28 & $6.1 \mathrm{E}-07$ \\
\hline Mm.311912 & Cys-rich transmembrane BMP regulator 1 (chordin like) & Crim1 & -2.29 & $9.9 \mathrm{E}-10$ \\
\hline Mm.331626 & Synaptic nuclear envelope 1 & Syne1 & -2.44 & $4.2 \mathrm{E}-07$ \\
\hline Mm.439824 & Similar to Protein tyrosine phosphatase type IVA protein 2 & PRL-2 & -2.48 & $5.3 \mathrm{E}-12$ \\
\hline Mm.259197 & RNA binding motif protein 5 & Rbm5 & -2.57 & $1.7 \mathrm{E}-08$ \\
\hline Mm.12926 & Mediator complex subunit 1 & Med1 & -2.58 & $6.7 \mathrm{E}-12$ \\
\hline Mm.203921 & OTU domain. ubiquitin aldehyde binding 1 & Otub1 & -2.59 & $5.3 \mathrm{E}-10$ \\
\hline Mm.455873 & Nuclear receptor interacting protein 1 & Nrip1 & -2.62 & $1.7 \mathrm{E}-05$ \\
\hline Mm.259197 & RNA binding motif protein 5 & Rbm5 & -2.68 & $2.4 \mathrm{E}-08$ \\
\hline Mm.343607 & $\mathrm{K}+$ calcium-activated channel. subfamily M. member 1 & Kcnma1 & -3.55 & $4.0 \mathrm{E}-10$ \\
\hline Mm.252063 & Myelin basic protein & $\mathrm{Mbp}$ & -3.85 & $5.4 \mathrm{E}-11$ \\
\hline Mm.450416 & Chemokine (C-C motif) ligand 21 & $\mathrm{Ccl} 21$ & -4.17 & $4.2 \mathrm{E}-14$ \\
\hline Mm.270999 & GATA zinc finger domain containing 2B & Gatad2b & -7.22 & 9.0E-14 \\
\hline Mm.2082 & Apolipoprotein D & Apod & -43.55 & $0.0 \mathrm{E}+00$ \\
\hline
\end{tabular}


Table S4. Genes differentially expressed in hApoD-Tg cerebellum in control conditions (Fold change $\geq+/-2$ )

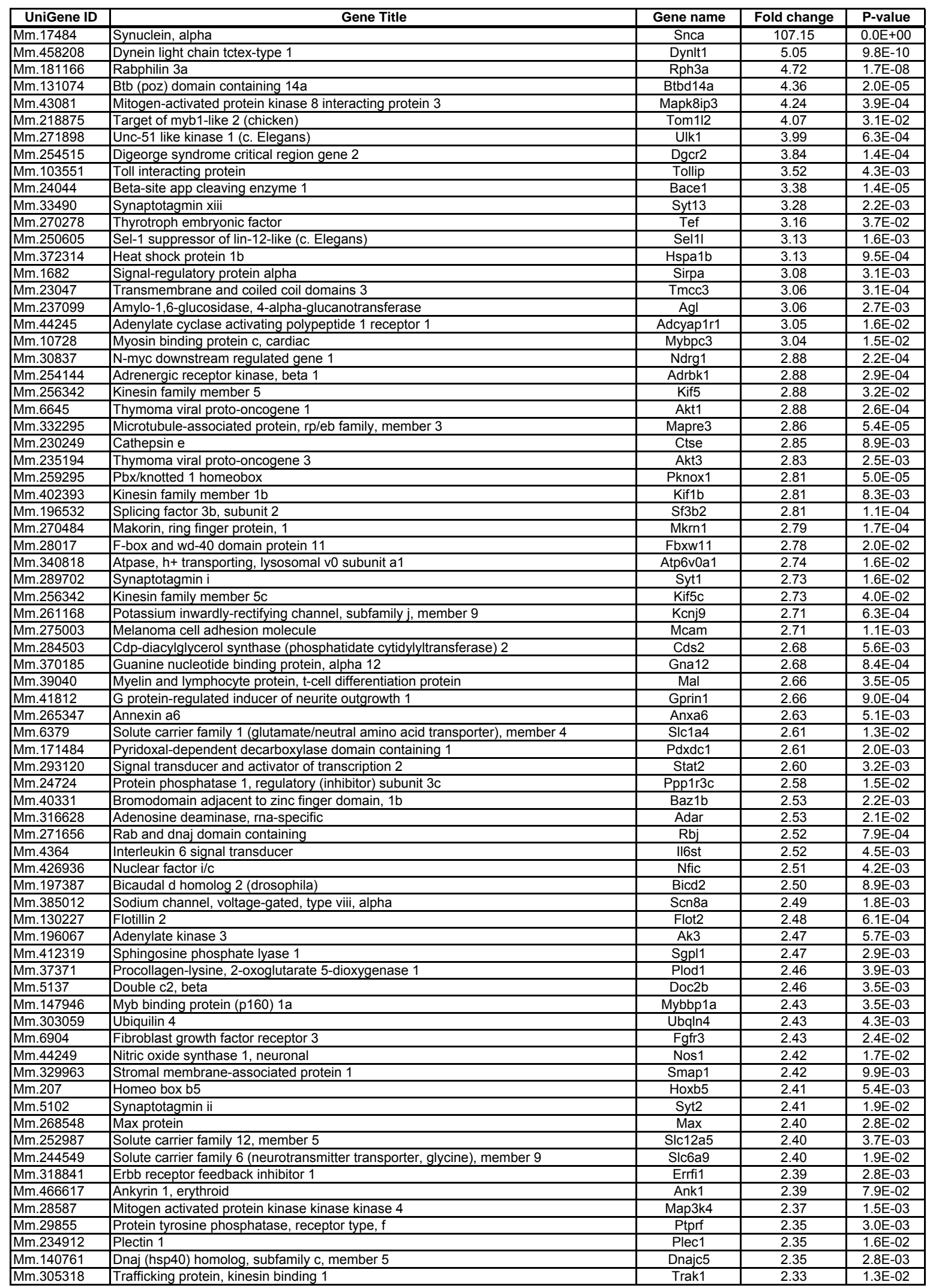




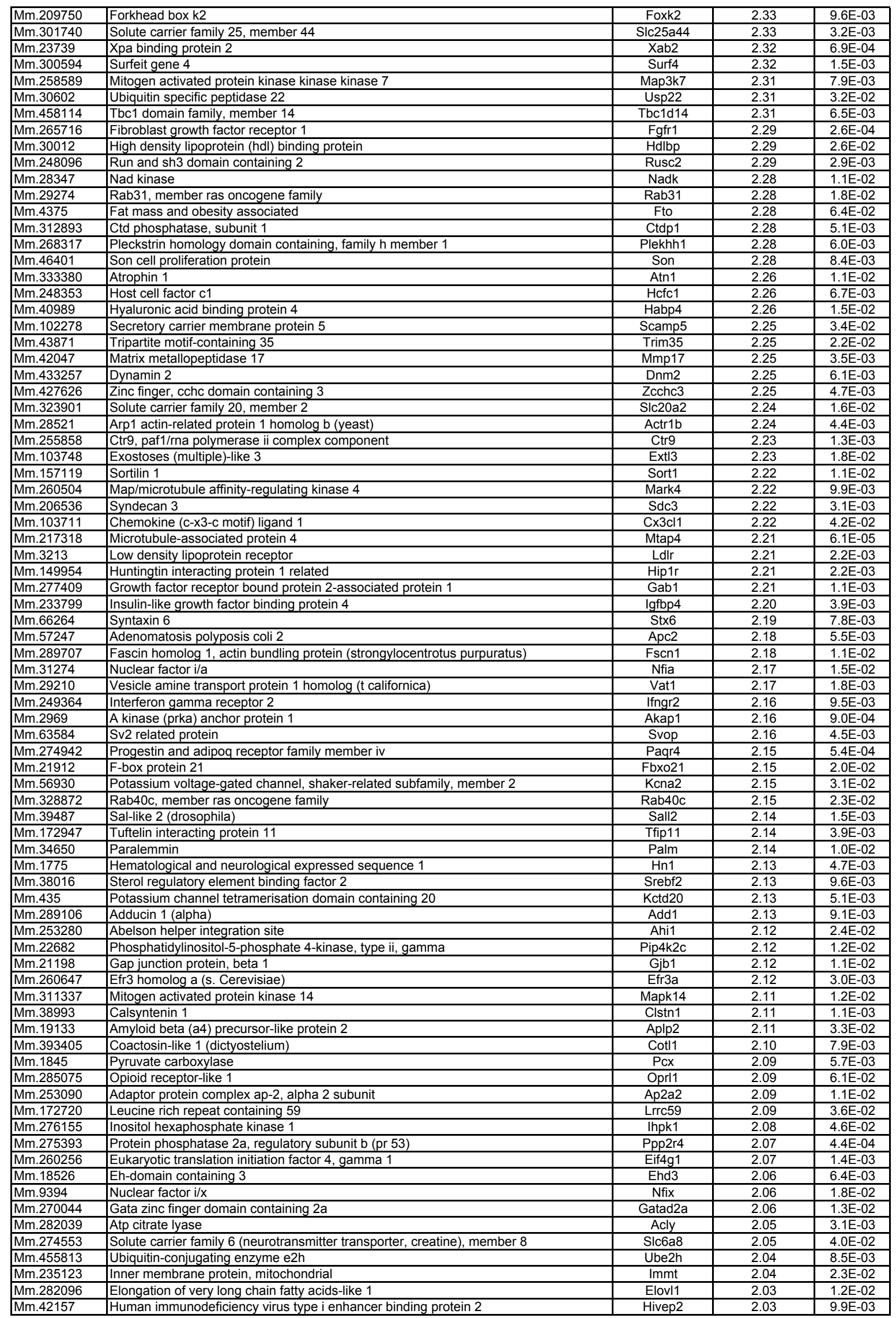




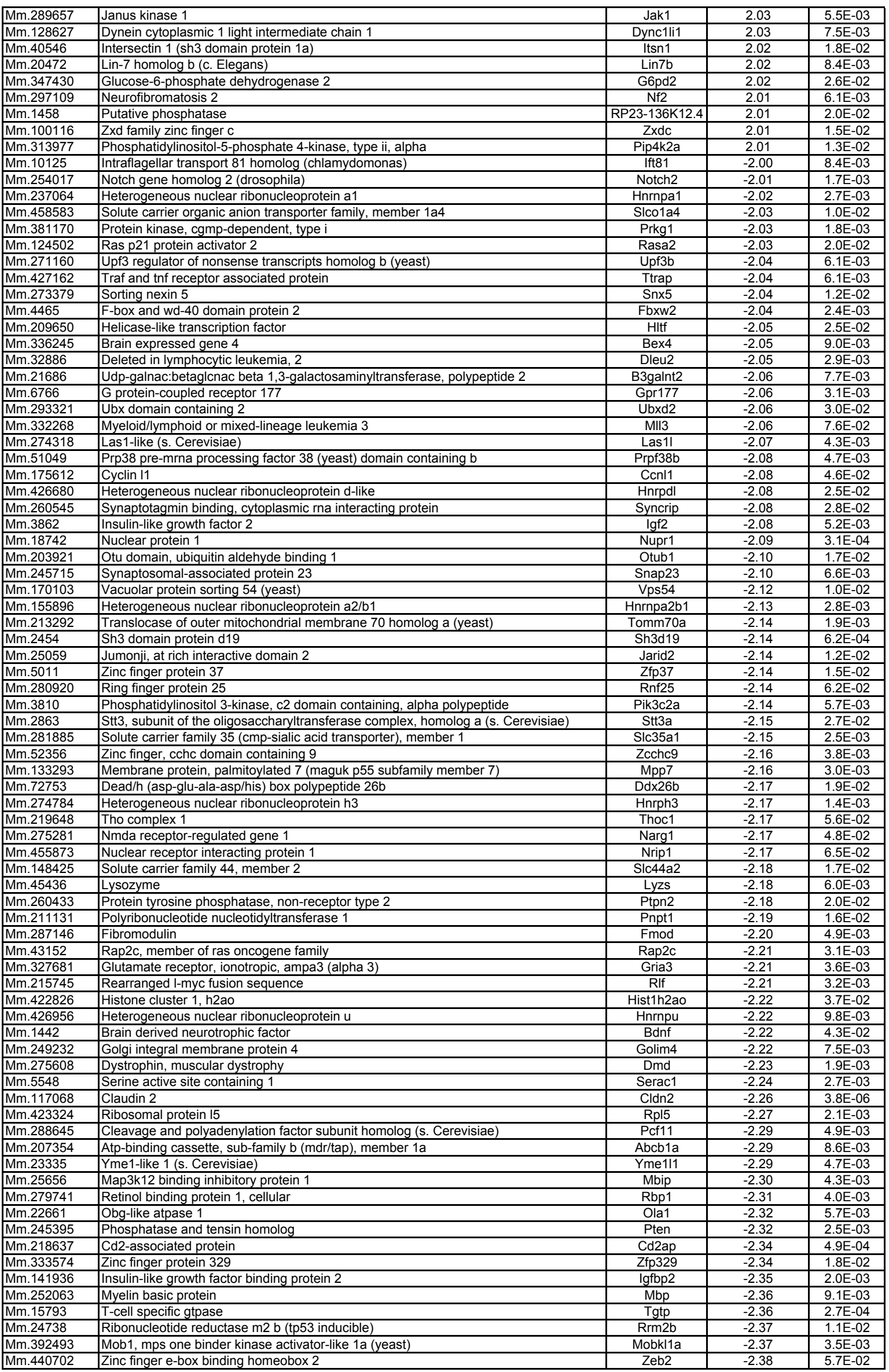




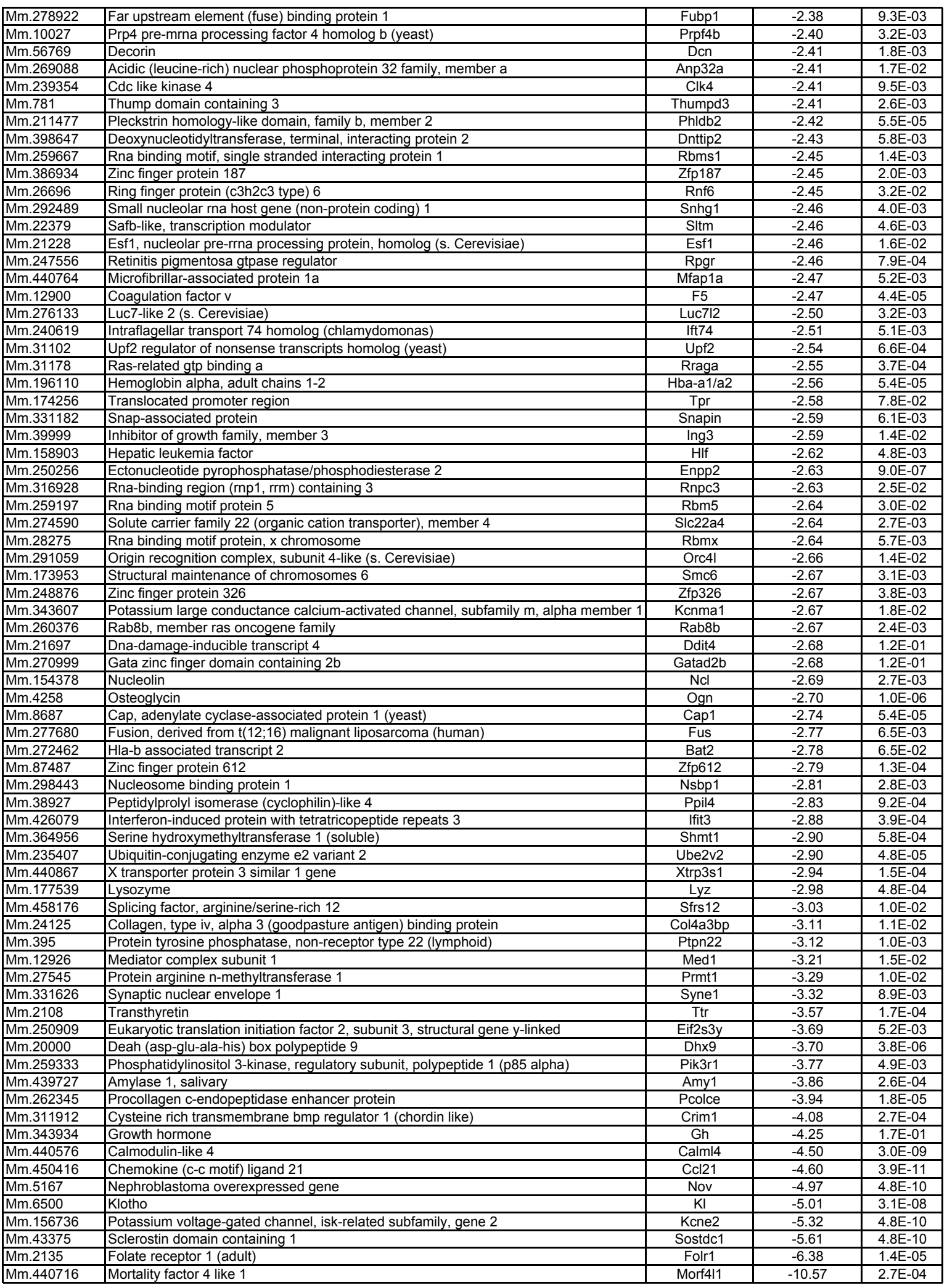


Table S5. PQ-regulated genes in WT cerebellum (Fold change $\geq+/-2$ )

\begin{tabular}{|c|c|c|c|c|}
\hline UniGene ID & Gene Title & Gene Symbol & Fold change & P-value \\
\hline $\mathrm{Mm} .466916$ & Plasma membrane associated protein, S3-12 & S3-12 & 25.25 & $0.00 \mathrm{E}+00$ \\
\hline Mm.336410 & Serum/glucocorticoid regulated kinase 3 & Sgk3 & 19.58 & $0.00 \mathrm{E}+00$ \\
\hline Mm.276405 & FK506 binding protein 5 & Fkbp5 & 12.83 & $0.00 \mathrm{E}+00$ \\
\hline Mm.195663 & Cyclin-dependent kinase inhibitor 1A (P21) & Cdkn1a & 11.79 & $3.89 \mathrm{E}-15$ \\
\hline Mm.368982 & Sulfotransferase family $1 \mathrm{~A}$, phenol-preferring, member 1 & Sult1a1 & 7.44 & $4.14 \mathrm{E}-14$ \\
\hline Mm.239655 & C-mer proto-oncogene tyrosine kinase & Mertk & 5.97 & $7.41 \mathrm{E}-14$ \\
\hline Mm.9537 & Lipocalin 2 & Lcn2 & 5.74 & $8.88 \mathrm{E}-13$ \\
\hline Mm.410189 & Thioredoxin interacting protein & Txnip & 5.66 & $2.53 \mathrm{E}-14$ \\
\hline Mm.193632 & Polymerase (RNA) III (DNA directed) polypeptide E & Polr3e & 5.52 & $3.33 \mathrm{E}-15$ \\
\hline $\mathrm{Mm} .27467$ & Ras homolog gene family, member J & Rhoj & 5.14 & $2.94 \mathrm{E}-12$ \\
\hline Mm.196189 & Angiopoietin-like 4 & Angpt|4 & 4.83 & $1.25 \mathrm{E}-14$ \\
\hline Mm.425294 & SH2B adaptor protein 2 & Sh2b2 & 4.59 & $1.75 \mathrm{E}-12$ \\
\hline Mm.11223 & Xanthine dehydrogenase & Xdh & 4.58 & 1.14E-10 \\
\hline Mm.29998 & Patatin-like phospholipase domain containing 2 & Pnpla2 & 4.49 & $5.08 \mathrm{E}-13$ \\
\hline Mm.347407 & CCAAT/enhancer binding protein (C/EBP), delta & Cebpd & 4.34 & $1.05 \mathrm{E}-11$ \\
\hline Mm.266840 & ADP-ribosylation factor-like 4D & Arl4d & 4.33 & $1.13 \mathrm{E}-11$ \\
\hline Mm.389856 & Zinc finger protein 36 & Zfp36 & 3.66 & $1.37 \mathrm{E}-11$ \\
\hline Mm.171378 & Uncoupling protein 2 (mitochondrial, proton carrier) & Ucp2 & 3.65 & $1.22 \mathrm{E}-12$ \\
\hline Mm.21697 & DNA-damage-inducible transcript 4 & Ddit4 & 3.61 & $3.91 \mathrm{E}-07$ \\
\hline Mm.281298 & Growth arrest and DNA-damage-inducible 45 gamma & Gadd45g & 3.52 & $1.84 \mathrm{E}-12$ \\
\hline Mm.46016 & Procollagen C-endopeptidase enhancer 2 & Pcolce2 & 3.49 & $2.45 \mathrm{E}-11$ \\
\hline $\mathrm{Mm} .457803$ & Zinc finger and BTB domain containing 16 & Zbtb16 & 3.49 & $1.88 \mathrm{E}-10$ \\
\hline Mm.235547 & Pyruvate dehydrogenase kinase, isoenzyme 4 & Pdk4 & 3.48 & $4.55 \mathrm{E}-10$ \\
\hline Mm.260698 & Receptor (calcitonin) activity modifying protein 2 & Ramp2 & 3.47 & 4.37E-09 \\
\hline Mm.33498 & Leucine rich repeat containing 33 & Lrrc33 & 3.47 & $1.61 \mathrm{E}-12$ \\
\hline Mm.410189 & Thioredoxin interacting protein & Txnip & 3.39 & $4.18 \mathrm{E}-11$ \\
\hline $\mathrm{Mm} .170515$ & Nuclear factor of kappa light chain gene enhancer in B-cells inhibitor, alpha & Nfkbia & 3.32 & $1.71 \mathrm{E}-10$ \\
\hline $\mathrm{Mm} .388$ & Adenosine deaminase & Ada & 3.22 & $7.27 \mathrm{E}-13$ \\
\hline Mm.29891 & Forkhead box 01 & Foxo1 & 3.21 & $1.49 \mathrm{E}-08$ \\
\hline Mm.17898 & Cold inducible RNA binding protein & Cirbp & 3.10 & $4.96 \mathrm{E}-11$ \\
\hline Mm.390108 & CKLF-like MARVEL transmembrane domain containing 3 & Cmtm3 & 2.96 & 3.94E-09 \\
\hline Mm.205854 & Transmembrane protein 166 & Tmem166 & 2.95 & 8.79E-09 \\
\hline Mm.330731 & Transglutaminase 2 , C polypeptide & $\operatorname{Tgm} 2$ & 2.94 & $1.47 \mathrm{E}-09$ \\
\hline Mm.393058 & Connective tissue growth factor & Ctgf & 2.86 & $1.02 \mathrm{E}-09$ \\
\hline $\mathrm{Mm} .30$ & Spla/ryanodine receptor domain and SOCS box containing 1 & Spsb1 & 2.84 & $1.88 \mathrm{E}-09$ \\
\hline Mm.292489 & Small nucleolar RNA host gene (non-protein coding) 1 & Snhg1 & 2.78 & $4.39 \mathrm{E}-10$ \\
\hline Mm.348025 & Leucine-rich alpha-2-glycoprotein 1 & Lrg1 & 2.72 & $2.85 \mathrm{E}-11$ \\
\hline Mm.27335 & Gamma-butyrobetaine hydroxylase & Bbox1 & 2.70 & $2.49 \mathrm{E}-08$ \\
\hline $\mathrm{Mm} .7598$ & Hairless & $\mathrm{Hr}$ & 2.70 & $2.68 \mathrm{E}-09$ \\
\hline Mm.318841 & ERBB receptor feedback inhibitor 1 & Errfi1 & 2.68 & $2.26 \mathrm{E}-07$ \\
\hline $\mathrm{Mm} .147226$ & Metallothionein 2 & Mt2 & 2.67 & $1.11 \mathrm{E}-15$ \\
\hline Mm.330731 & Transglutaminase 2 , C polypeptide & Tgm2 & 2.66 & $1.05 \mathrm{E}-08$ \\
\hline Mm.142095 & Calcium regulated heat stable protein 1 & Carhsp1 & 2.66 & $2.28 \mathrm{E}-07$ \\
\hline Mm.391777 & Max dimerization protein 4 & Mxd4 & 2.65 & $4.13 \mathrm{E}-08$ \\
\hline Mm.330731 & Transglutaminase 2 , C polypeptide & Tgm2 & 2.64 & $2.01 \mathrm{E}-09$ \\
\hline $\mathrm{Mm} .738$ & Collagen, type IV, alpha 1 & Col4a1 & 2.62 & $7.79 \mathrm{E}-08$ \\
\hline Mm.24724 & Protein phosphatase 1, regulatory (inhibitor) subunit 3C & Ppp1r3c & 2.61 & $1.36 \mathrm{E}-07$ \\
\hline Mm.330731 & Transglutaminase 2 , C polypeptide & Tgm2 & 2.52 & $1.91 \mathrm{E}-07$ \\
\hline $\mathrm{Mm} .28405$ & Serum/glucocorticoid regulated kinase 1 & Sgk1 & 2.51 & $9.38 \mathrm{E}-14$ \\
\hline Mm.21389 & Deiodinase, iodothyronine, type II & Dio2 & 2.49 & $2.88 \mathrm{E}-09$ \\
\hline Mm.36640 & Mitogen-activated protein kinase kinase kinase 6 & Map3k6 & 2.45 & $5.34 \mathrm{E}-09$ \\
\hline $\mathrm{Mm} .393018$ & Transformation related protein 53 inducible nuclear protein 1 & Trp53inp1 & 2.44 & $9.96 \mathrm{E}-11$ \\
\hline Mm.439734 & Cytotoxic T Iymphocyte-associated protein 2 & Ctla2 & 2.42 & $2.97 \mathrm{E}-07$ \\
\hline Mm.182927 & Mitochondrial ribosomal protein L15 & Mrpl15 & 2.39 & 3.09E-09 \\
\hline Mm.260869 & HIV-1 Rev binding protein-like & $\mathrm{Hrbl}$ & 2.36 & $2.00 \mathrm{E}-06$ \\
\hline Mm.12906 & Dopa decarboxylase & Ddc & 2.34 & $1.08 \mathrm{E}-07$ \\
\hline Mm.22216 & TSC22 domain family 3 & Tsc22d3 & 2.32 & $7.41 \mathrm{E}-13$ \\
\hline Mm.135110 & Hypoxia inducible factor 3 , alpha subunit & Hif3a & 2.27 & $1.15 \mathrm{E}-08$ \\
\hline Mm.21855 & Peptidoglycan recognition protein 1 & Pglyrp1 & 2.26 & $6.66 \mathrm{E}-09$ \\
\hline Mm.391933 & LIM domain containing preferred translocation partner in lipoma & Lpp & 2.25 & $2.21 \mathrm{E}-07$ \\
\hline Mm.30144 & Cytotoxic T lymphocyte-associated protein 2 alpha & Ctla2a & 2.22 & $1.61 \mathrm{E}-05$ \\
\hline $\mathrm{Mm} .2760$ & Zinc finger and SCAN domain containing 21 & Zscan21 & 2.19 & $9.22 \mathrm{E}-07$ \\
\hline Mm.318841 & ERBB receptor feedback inhibitor 1 & Errfi1 & 2.19 & $7.60 \mathrm{E}-12$ \\
\hline Mm.455819 & SRY-box containing gene 4 & Sox4 & 2.18 & $7.45 \mathrm{E}-05$ \\
\hline Mm.291707 & Cullin 2 & Cul2 & 2.18 & $1.05 \mathrm{E}-06$ \\
\hline Mm.170515 & Nuclear factor of kappa light chain gene enhancer in B-cells inhibitor, alpha & Nfkbia & 2.17 & 5.79E-09 \\
\hline Mm.21002 & Solute carrier family 2 (facilitated glucose transporter), member 1 & Slc2a1 & 2.17 & $1.71 \mathrm{E}-08$ \\
\hline Mm.21687 & LIM domain containing 2 & Limd2 & 2.17 & $2.38 \mathrm{E}-05$ \\
\hline Mm.24105 & Nuclear distribution gene E homolog 1 (A nidulans) & Nde1 & 2.17 & $1.46 \mathrm{E}-06$ \\
\hline Mm.279998 & High mobility group box 2 & $\mathrm{Hmgb2}$ & 2.17 & $4.08 \mathrm{E}-06$ \\
\hline Mm.168257 & Ras homolog gene family, member U & Rhou & 2.16 & $7.06 \mathrm{E}-07$ \\
\hline
\end{tabular}




\begin{tabular}{|c|c|c|c|c|}
\hline Mm.28456 & Proline dehydrogenase & Prodh & 2.16 & $9.45 \mathrm{E}-07$ \\
\hline Mm.222831 & Potassium voltage-gated channel, shaker-related subfamily, member 5 & Kcna5 & 2.15 & $1.40 \mathrm{E}-08$ \\
\hline Mm.306038 & Zinc finger protein 810 & Zfp810 & 2.15 & $2.59 \mathrm{E}-07$ \\
\hline $\mathrm{Mm} .24513$ & Solute carrier family 25, member 13 & Slc25a13 & 2.15 & $5.69 \mathrm{E}-09$ \\
\hline Mm.41984 & Proline rich 15 & Prr15 & 2.14 & 1.24E-08 \\
\hline Mm.209385 & LIM domain containing preferred translocation partner in lipoma & Lpp & 2.13 & $1.00 \mathrm{E}-07$ \\
\hline Mm.248337 & Vasorin & Vasn & 2.13 & 1.01E-05 \\
\hline Mm.389243 & Patatin-like phospholipase domain containing 7 & Pnpla7 & 2.12 & $3.67 \mathrm{E}-06$ \\
\hline Mm.247036 & Xeroderma pigmentosum, complementation group A & Xpa & 2.12 & $9.65 \mathrm{E}-06$ \\
\hline Mm.398690 & Serum deprivation response & Sdpr & 2.12 & $1.86 \mathrm{E}-07$ \\
\hline Mm.29395 & Glycine N-methyltransferase & Gnmt & 2.11 & $4.45 \mathrm{E}-07$ \\
\hline Mm.297074 & Zinc finger, NFX1-type containing 1 & Znfx1 & 2.10 & $4.75 \mathrm{E}-06$ \\
\hline Mm.316894 & Syntaxin binding protein $3 \mathrm{~A} / / /$ similar to vesicle transport protein & Stxbp3a & 2.09 & $1.24 \mathrm{E}-08$ \\
\hline Mm.246398 & TCDD-inducible poly(ADP-ribose) polymerase & Tiparp & 2.09 & 1.39E-07 \\
\hline $\mathrm{Mm} .212812$ & Spinster homolog 2 (Drosophila) & Spns2 & 2.07 & 1.60E-07 \\
\hline Mm.21389 & Deiodinase, iodothyronine, type II & Dio2 & 2.07 & $1.50 \mathrm{E}-06$ \\
\hline Mm.41389 & Kruppel-like factor 15 & Klf15 & 2.07 & 5.67E-09 \\
\hline Mm.250731 & Microtubule associated serine/threonine kinase 3 & Mast3 & 2.04 & $9.06 \mathrm{E}-06$ \\
\hline Mm.6949 & AF4/FMR2 family, member 1 & Aff1 & 2.03 & 1.34E-06 \\
\hline Mm.146984 & Proteasome (prosome, macropain) inhibitor subunit 1 & Psmf1 & 2.03 & $1.40 \mathrm{E}-06$ \\
\hline Mm.23095 & Chromatin accessibility complex 1 & Chrac1 & 2.00 & $1.18 \mathrm{E}-07$ \\
\hline Mm.42190 & UNC homeobox & Uncx & -2.01 & $2.17 \mathrm{E}-06$ \\
\hline Mm.277680 & Fusion, derived from t(12;16) malignant liposarcoma (human) & Fus & -2.02 & 1.99E-06 \\
\hline $\mathrm{Mm} .35413$ & Polycomb group ring finger 6 & Pcgf6 & -2.02 & 1.74E-06 \\
\hline Mm.200692 & Eomesodermin homolog (Xenopus laevis) & Eomes & -2.03 & 1.74E-06 \\
\hline Mm.257276 & Similar to PTB-associated splicing factor & Sfpq & -2.03 & $5.42 \mathrm{E}-09$ \\
\hline $\mathrm{Mm} .23156$ & A disintegrin-like and metallopeptidase with thrombospondin type 1 motif, 4 & Adamts4 & -2.05 & $4.71 \mathrm{E}-06$ \\
\hline Mm.29496 & CREB/ATF bzip transcription factor & Crebzf & -2.09 & 1.47E-06 \\
\hline Mm.16340 & Fibroblast growth factor receptor 2 & Fgfr2 & -2.10 & $2.89 \mathrm{E}-07$ \\
\hline Mm.44065 & Chemokine (C-X3-C) receptor 1 & Cx3cr1 & -2.13 & 9.09E-07 \\
\hline Mm.284495 & Solute carrier organic anion transporter family, member 1c1 & Slco1c1 & -2.15 & 1.33E-08 \\
\hline Mm.14313 & Endothelial-specific receptor tyrosine kinase & Tek & -2.16 & 3.19E-08 \\
\hline Mm.306021 & UDP galactosyltransferase $8 \mathrm{~A}$ & Ugt8a & -2.17 & $5.85 \mathrm{E}-07$ \\
\hline Mm.286127 & ELOVL family member 7 , elongation of long chain fatty acids (yeast) & Elovl7 & -2.21 & 1.07E-06 \\
\hline Mm.1425 & Adenylate cyclase 8 & Adcy8 & -2.22 & $9.65 \mathrm{E}-08$ \\
\hline Mm.65396 & SRY-box containing gene 2 & Sox2 & -2.29 & $9.04 \mathrm{E}-10$ \\
\hline Mm.24096 & Thrombomodulin & Thbd & -2.30 & $8.50 \mathrm{E}-08$ \\
\hline $\mathrm{Mm} .32886$ & Deleted in lymphocytic leukemia, 2 & Dleu2 & -2.40 & $2.07 \mathrm{E}-07$ \\
\hline Mm.276739 & SRY-box containing gene 10 & Sox10 & -2.41 & $2.43 \mathrm{E}-08$ \\
\hline Mm.266679 & Tribbles homolog 2 (Drosophila) & Trib2 & -2.42 & 1.29E-09 \\
\hline Mm.22768 & Claudin 5 & Cldn5 & -2.44 & $2.16 \mathrm{E}-08$ \\
\hline Mm.22708 & Serine (or cysteine) peptidase inhibitor, clade $\mathrm{H}$, member 1 & Serpinh1 & -2.50 & 4.39E-07 \\
\hline Mm.373043 & V-erb-b2 erythroblastic leukemia viral oncogene homolog 3 (avian) & Erbb3 & -2.55 & 1.75E-09 \\
\hline Mm.156736 & Potassium voltage-gated channel, Isk-related subfamily, gene 2 & Kcne2 & -2.59 & $8.20 \mathrm{E}-09$ \\
\hline Mm.277409 & Growth factor receptor bound protein 2-associated protein 1 & Gab1 & -2.63 & 3.87E-07 \\
\hline $\mathrm{Mm} .3507$ & Nuclear receptor subfamily 4 , group $A$, member 2 & $\mathrm{Nr} 4 \mathrm{a} 2$ & -2.69 & $9.36 \mathrm{E}-08$ \\
\hline Mm.270999 & GATA zinc finger domain containing 2B & Gatad2b & -2.73 & $7.85 \mathrm{E}-03$ \\
\hline $\mathrm{Mm} .307488$ & CDC42 effector protein (Rho gtpase binding) 1 & Cdc42ep1 & -2.77 & $3.63 \mathrm{E}-08$ \\
\hline Mm.119 & Nuclear receptor subfamily 4, group $A$, member 1 & $\mathrm{Nr} 4 \mathrm{a} 1$ & -2.83 & 1.03E-09 \\
\hline Mm.20144 & Serine (or cysteine) peptidase inhibitor, clade B, member 1a & Serpinb1a & -3.18 & 1.39E-09 \\
\hline Mm.176695 & Tripartite motif-containing 59 & Trim59 & -3.63 & $8.54 \mathrm{E}-09$ \\
\hline Mm.303231 & Chemokine (C-X-C motif) ligand 12 & Cxcl12 & -3.65 & $1.87 \mathrm{E}-11$ \\
\hline Mm.246513 & FBJ osteosarcoma oncogene & Fos & -9.59 & $0.00 \mathrm{E}+00$ \\
\hline
\end{tabular}


Table S6. PQ-regulated genes specific for WT (Fold change $\geq+/-2$ )

\begin{tabular}{|c|c|c|c|c|}
\hline UniGene ID & Gene Title & Gene Symbol & Fold Change & P-value \\
\hline Mm.389856 & Zinc finger protein 36 & Zfp36 & 3.77 & 3.55E-09 \\
\hline Mm.33498 & Leucine rich repeat containing 33 & Lrrc33 & 3.44 & $3.19 \mathrm{E}-09$ \\
\hline Mm.21697 & DNA-damage-inducible transcript 4 & Ddit4 & 3.42 & $7.36 \mathrm{E}-05$ \\
\hline Mm.738 & Collagen, type IV, alpha 1 & Col4a1 & 2.63 & 2.04E-05 \\
\hline Mm.21389 & Deiodinase, iodothyronine, type II & Dio2 & 2.52 & 7.32E-07 \\
\hline Mm.260869 & HIV-1 Rev binding protein-like & $\mathrm{Hrbl}$ & 2.41 & $2.16 \mathrm{E}-04$ \\
\hline Mm.279998 & High mobility group box 2 & Hmgb2 & 2.28 & $2.58 \mathrm{E}-04$ \\
\hline Mm.391933 & LIM domain containing preferred translocation partner & $\mathrm{Lpp}$ & 2.28 & 1.34E-05 \\
\hline Mm.247036 & Xeroderma pigmentosum, complementation group A & Xpa & 2.24 & $4.43 \mathrm{E}-04$ \\
\hline Mm.182927 & Mitochondrial ribosomal protein L15 & Mrpl15 & 2.23 & 9.32E-07 \\
\hline Mm.2760 & Zinc finger and SCAN domain containing 21 & Zscan21 & 2.21 & $5.48 \mathrm{E}-05$ \\
\hline Mm.30144 & Cytotoxic T lymphocyte-associated protein 2 alpha & Ctla2a & 2.2 & 1.02E-03 \\
\hline Mm.291707 & Cullin 2 & Cul2 & 2.19 & $7.27 \mathrm{E}-05$ \\
\hline Mm.389243 & Patatin-like phospholipase domain containing 7 & Pnpla7 & 2.19 & $2.22 \mathrm{E}-04$ \\
\hline Mm.29395 & Glycine N-methyltransferase & Gnmt & 2.17 & 2.27E-05 \\
\hline Mm.24513 & Solute carrier family 25 (mitochondrial carrier), member 13 & Slc25a13 & 2.16 & $6.17 \mathrm{E}-07$ \\
\hline Mm.306038 & Zinc finger protein 810 & Zfp810 & 2.16 & 2.33E-05 \\
\hline Mm.455819 & SRY-box containing gene 4 & Sox4 & 2.15 & $3.43 \mathrm{E}-03$ \\
\hline Mm.28456 & Proline dehydrogenase & Prodh & 2.13 & $1.06 \mathrm{E}-04$ \\
\hline Mm.246398 & TCDD-inducible poly(ADP-ribose) polymerase & Tiparp & 2.11 & 5.73E-05 \\
\hline Mm.41389 & Kruppel-like factor 15 & Klf15 & 2.09 & 9.65E-07 \\
\hline Mm.212812 & Spinster homolog 2 (Drosophila) & Spns2 & 2.07 & 9.84E-06 \\
\hline Mm.439656 & CCAAT/enhancer binding protein (C/EBP), beta & Cebpb & 2.06 & $7.00 \mathrm{E}-04$ \\
\hline Mm.250731 & Microtubule associated serine/threonine kinase 3 & Mast3 & 2.05 & $3.63 \mathrm{E}-04$ \\
\hline Mm.398690 & Serum deprivation response & Sdpr & 2.05 & $3.17 \mathrm{E}-05$ \\
\hline Mm.146984 & Proteasome (prosome, macropain) inhibitor subunit 1 & Psmf1 & 2.03 & $2.10 \mathrm{E}-04$ \\
\hline Mm.2114 & Thrombospondin 3 & Thbs3 & 2.03 & $4.66 \mathrm{E}-06$ \\
\hline Mm.6949 & AF4/FMR2 family, member 1 & Aff1 & 2.02 & 1.38E-04 \\
\hline Mm.23095 & Chromatin accessibility complex 1 & Chrac1 & 2.02 & $8.79 \mathrm{E}-05$ \\
\hline Mm.248337 & Vasorin & Vasn & 2.01 & 6.69E-04 \\
\hline Mm.1571 & Cadherin 11 & Cdh11 & -2.01 & $7.19 \mathrm{E}-04$ \\
\hline Mm.2901 & TYRO3 protein tyrosine kinase 3 & Tyro3 & -2.02 & 1.99E-04 \\
\hline Mm.200692 & Eomesodermin homolog (Xenopus laevis) & Eomes & -2.03 & 9.40E-06 \\
\hline Mm.29496 & CREB/ATF bZIP transcription factor & Crebzf & -2.05 & $3.73 \mathrm{E}-04$ \\
\hline Mm.257276 & Splicing factor proline/glutamine rich & Sfpq & -2.05 & 5.42E-09 \\
\hline Mm.35413 & Polycomb group ring finger 6 & Pcgf6 & -2.09 & $2.67 \mathrm{E}-04$ \\
\hline Mm.286127 & ELOVL family 7 , elongation of long chain fatty acids & Elovl7 & -2.11 & 4.74E-04 \\
\hline Mm.284495 & Solute carrier organic anion transporter family, 1c1 & Slco1c1 & -2.11 & 4.58E-06 \\
\hline Mm.14313 & Endothelial-specific receptor tyrosine kinase & Tek & -2.17 & 7.90E-06 \\
\hline $\mathrm{Mm} .1425$ & Adenylate cyclase 8 & Adcy8 & -2.22 & $1.90 \mathrm{E}-05$ \\
\hline Mm.306021 & UDP galactosyltransferase $8 \mathrm{~A}$ & Ugt8a & -2.25 & 9.66E-05 \\
\hline Mm.65396 & SRY-box containing gene 2 & Sox2 & -2.28 & $2.36 \mathrm{E}-07$ \\
\hline Mm.276739 & SRY-box containing gene 10 & Sox10 & -2.31 & 9.25E-06 \\
\hline Mm.22768 & Claudin 5 & Cldn5 & -2.41 & $7.90 \mathrm{E}-06$ \\
\hline Mm.22708 & Serine (or cysteine) peptidase inhibitor, clade $\mathrm{H}$, member 1 & Serpinh1 & -2.47 & 9.57E-06 \\
\hline Mm.156736 & K+ voltage-gated channel, Isk-related subfamily, gene 2 & Kcne2 & -2.5 & $2.30 \mathrm{E}-06$ \\
\hline Mm.32886 & Deleted in lymphocytic leukemia, 2 & Dleu2 & -2.57 & $2.04 \mathrm{E}-05$ \\
\hline
\end{tabular}


Table S7. PQ-regulated genes specific for ApoD-KO (Fold change $\geq+/-2$ )

\begin{tabular}{|c|c|c|c|c|}
\hline UniGene ID & Gene Title & Gene Symbol & Fold change & P-value \\
\hline Mm.29274 & RAB31, member RAS oncogene family & Rab31 & 3,02 & 2,31E-06 \\
\hline Mm.2082 & Apolipoprotein D & Apod & 2,98 & $6,51 \mathrm{E}-04$ \\
\hline Mm.4606 & Branched chain aminotransferase 1, cytosolic & Bcat1 & 2,42 & 1,31E-05 \\
\hline $\mathrm{Mm} .288381$ & Fibulin 5 & Fbln5 & 2,23 & $3,54 \mathrm{E}-03$ \\
\hline Mm.291826 & Adiponectin receptor 2 & Adipor2 & 2,22 & $1,15 \mathrm{E}-06$ \\
\hline Mm.389232 & Leucine rich repeat containing $8 \mathrm{~A}$ & Lrrc8a & 2,2 & $1,60 \mathrm{E}-03$ \\
\hline $\mathrm{Mm} .40338$ & Growth arrest specific 7 & Gas7 & 2,15 & 1,55E-05 \\
\hline Mm.277092 & Hephaestin & Heph & 2,1 & $2,70 \mathrm{E}-05$ \\
\hline Mm.85429 & Six transmembrane epithelial antigen of the prostate 1 & Steap1 & 2,05 & 3,37E-05 \\
\hline Mm.3440 & Adenylosuccinate synthetase like 1 & Adssl1 & 2,04 & $3,09 \mathrm{E}-05$ \\
\hline Mm.347398 & B-cell leukemia/lymphoma 6 & $\mathrm{Bcl} 6$ & 2,04 & $5,05 \mathrm{E}-05$ \\
\hline Mm.12834 & O-fucosylpeptide 3-beta-N-acetylglucosaminyltransferase & Lfing & 2,03 & $1,69 \mathrm{E}-04$ \\
\hline Mm.196067 & Adenylate kinase 3 & Ak3 & 2,01 & 1,02E-03 \\
\hline Mm.2314 & Protein kinase $\mathrm{C}$, delta & Prkcd & 2 & $1,11 \mathrm{E}-05$ \\
\hline Mm.454219 & Tenascin C & Tnc & -2 & $1,21 \mathrm{E}-05$ \\
\hline Mm.278444 & Transducin-like enhancer of split 1, homolog of E(spl) & Tle1 & $-2,02$ & $3,18 \mathrm{E}-04$ \\
\hline Mm.330536 & Sema domain, semaphorin 6D & Sema6d & $-2,04$ & $2,42 \mathrm{E}-05$ \\
\hline Mm.209813 & Ephrin B2 & Efnb2 & $-2,06$ & $2,42 \mathrm{E}-05$ \\
\hline Mm.243632 & RELT-like 1 & Rell1 & $-2,06$ & $2,42 \mathrm{E}-05$ \\
\hline $\mathrm{Mm} .85410$ & SWI/SNF regulator of chromatin, subfamily c, member 1 & Smarcc1 & $-2,06$ & $5,41 \mathrm{E}-05$ \\
\hline Mm.293574 & Aspartoacylase (aminoacylase) 2 & Aspa & $-2,14$ & $6,45 \mathrm{E}-06$ \\
\hline Mm.274482 & Eukaryotic translation initiation factor $2 \mathrm{C}, 2$ & Eif2c2 & $-2,19$ & $8,44 \mathrm{E}-06$ \\
\hline Mm.276736 & Carboxypeptidase D & Cpd & $-2,2$ & $6,05 \mathrm{E}-02$ \\
\hline Mm.3781 & Phosphatidylinositol glycan anchor biosynthesis, class $\mathrm{A}$ & Piga & $-2,25$ & $2,70 \mathrm{E}-05$ \\
\hline Mm.4909 & Runt-related transcription factor 1 & Runx1t1 & $-2,25$ & $2,33 \mathrm{E}-05$ \\
\hline Mm.390167 & ELAV-like 3 (Hu antigen C) & Elavl3 & $-2,27$ & $5,95 \mathrm{E}-04$ \\
\hline Mm.3117 & Pleckstrin homology-like domain, family A, member 1 & Phlda1 & $-2,28$ & $1,01 \mathrm{E}-05$ \\
\hline Mm.290774 & Heat shock protein 8 & Hspa8 & $-2,42$ & $3,73 \mathrm{E}-04$ \\
\hline $\mathrm{Mm} .372314$ & Heat shock protein 1B & Hspa1b & $-2,58$ & $3,27 \mathrm{E}-05$ \\
\hline Mm.423621 & CD44 antigen & $\mathrm{Cd} 44$ & $-2,67$ & $8,14 \mathrm{E}-07$ \\
\hline Mm.458200 & Kruppel-like factor 7 (ubiquitous) & Klf7 & $-2,73$ & $2,99 \mathrm{E}-04$ \\
\hline
\end{tabular}


Table S8. PQ-regulated genes specific for hApoD-Tg (Fold change $\geq+/-2$ )

\begin{tabular}{|l|l|c|c|c|}
\hline \multicolumn{1}{|c|}{ UniGene ID } & \multicolumn{1}{|c|}{ Gene Title } & Gene Symbol & Fold change & P-value \\
\hline $\mathrm{Mm} .466916$ & Plasma membrane associated protein, S3-12 & S3-12 & 3.32 & $1.991 \mathrm{E}-03$ \\
\hline $\mathrm{Mm} .2135$ & Folate receptor 1 (adult) & Folr1 & 2.84 & $1.321 \mathrm{E}-03$ \\
\hline $\mathrm{Mm} .11223$ & Xanthine dehydrogenase & Xdh & 2.31 & $4.193 \mathrm{E}-03$ \\
\hline $\mathrm{Mm} .3815$ & Syndecan 4 & Sdc4 & 2.18 & $3.297 \mathrm{E}-02$ \\
\hline $\mathrm{Mm} .276405$ & FK506 binding protein 5 & Fkbp5 & 2.17 & $1.326 \mathrm{E}-02$ \\
\hline $\mathrm{Mm} .2108$ & Transthyretin & Ttr & 2.07 & $1.493 \mathrm{E}-03$ \\
\hline
\end{tabular}


Table S9. GO Terms enriched in ApoD-KO vs. WT comparison

\begin{tabular}{|l|l|r|r|r|l|}
\hline & \multicolumn{1}{|c|}{ GO terms } & Array \% & Genome \% & \multicolumn{1}{|c|}{$\boldsymbol{P}$ value } & Genes \\
\hline Molecular function & Transcription regulator activity & 25 & 7.67 & 0.025 & Nrip1, Nfia, Med1, Max, Gatad2b, Hnrnpab, Nr2c2 \\
\cline { 2 - 5 } & Cytoskeletal protein binding & 15.63 & 3.02 & 0.021 & Cap1, Syne1, Vapb, Kif1b, Sdc4 \\
\hline \multirow{3}{*}{ Cellular component } & Nucleus & 53.13 & 26.81 & 0.022 & $\begin{array}{l}\text { Nrip1, Nfia, Syne1, Med1, Dnmt3a, Max, Brd4, Gatad2b, Mbp, Hnrnpab, } \\
\text { Ywhaz, Rbm5, Nr2c2, Sfrs2, Rbbp4 }\end{array}$ \\
\cline { 2 - 5 } & Axon & 6.25 & 0.18 & 0.006 & Kcnma1, Mbp \\
\hline \multirow{3}{*}{ Biological process } & Regulation of transcription, DNA-dependent & 31.25 & 11.95 & 0.035 & Nrip1, Nfia, Med1, Dnmt3a, Max, Gatad2b, Hnrnpab, Nr2c2, Rbbp4 \\
\cline { 2 - 5 } & & & & \\
\cline { 2 - 5 } & Negative regulation of biological process & 28.13 & 9.22 & 0.022 & Nrip1, Ccl21, Dnmt3a, Kcnma1, Map3k7, Hnrnpab, Rbm5 \\
\cline { 2 - 5 } & Transmission of nerve impulse & 12.5 & 1.44 & 0.011 & Gria4, Kcnma1, Mbp, Kif1b \\
\cline { 2 - 5 } & Synaptic transmission & 9.38 & 1.09 & 0.022 & Gria4, Kcnma1, Kif1b \\
\hline
\end{tabular}


Table S10. GO Terms enriched in hApoD-Tg vs. WT comparison

\begin{tabular}{|c|c|c|c|c|c|}
\hline & GO terms & Array \% & Genome \% & $P$ value & Genes \\
\hline \multirow[t]{4}{*}{ Molecular function } & Secondary active transmembrane transporter activity & 3.266 & 1.009 & 0.017 & $\begin{array}{l}\text { Slc35a1, Slc22a4, Slc1a4, Slc12a5, Akt1, Slc6a20a, } \\
\text { Slc6a9, Slc12a6, Slc6a8, Ttr, Slc20a2 }\end{array}$ \\
\hline & Hormone receptor binding & 2.01 & 0.392 & 0.009 & Nrip1, Med1, Jak1, Gh, Atp6v0a1 \\
\hline & Phosphatidylserine decarboxylase activity & 1.508 & 0.035 & $<0.0001$ & Pisd-ps1, Pisd-ps3 \\
\hline & Retinoid binding & 1.005 & 0.084 & 0.006 & Rbp1, Ttr \\
\hline \multirow[t]{2}{*}{ Cellular component } & Cytoplasmic vesicle & 9.045 & 3.579 & 0.0001 & $\begin{array}{l}\text { Mapk8ip3, Ulk1, Ehd3, Ift74, Doc2b, Cd2ap, Pik3c2a, } \\
\text { Syt1, Bdnf, Nos1, Sort1, Slc1a4, Hip1r, Itsn1, Snapin, } \\
\text { Srebf2, Anxa6, Ap2a2, Gh, Dnajc5, F5, Syt2, Rph3a, } \\
\text { Scamp5, Bace1, Syt13, Kif1b, Svop, Gh, Atp6v0a1 }\end{array}$ \\
\hline & Neuron projection & 4.02 & 1.459 & 0.023 & $\begin{array}{l}\text { Mapk8ip3, Ulk1, Gria3, Nos1, Kcnma1, Mbp, Rnf6, Syt1, } \\
\text { Slc12a6, Mark4, Kif5a, Bace1, Kif5c, Scn8a, Inpp5k }\end{array}$ \\
\hline \multirow[t]{3}{*}{ Biological process } & Phospholipid metabolic process & 4.02 & 1.133 & 0.002 & $\begin{array}{l}\text { Pip4k2c, Snca, Pip4k2a, Pik3c2a, Pten, Pik3r1, Pisd, } \\
\text { Chpt1, Cds2 }\end{array}$ \\
\hline & Response to insulin stimulus & 2.261 & 0.414 & 0.003 & Ptpn2, Akt3, Sort1, Pik3r1, Akt1, Gh \\
\hline & \begin{tabular}{|l|} 
Neurotransmitter transport \\
\end{tabular} & 2.01 & 0.463 & 0.025 & Snapin, Syt1, Slc6a9, Slc6a8, Lin7b, Rph3a \\
\hline
\end{tabular}


Table S11. GO terms enrichment in WT PQ-regulated genes

\begin{tabular}{|c|c|c|c|c|c|}
\hline & GO terms & Array \% & Genome \% & $P$ value & Genes \\
\hline \multirow[t]{2}{*}{ Molecular function } & Nucleic acid binding transcription factor activity & 14.19 & 4.9 & 0.00045 & $\begin{array}{l}\text { Aff1, Cebpd, Crebzf, Eomes, Fos, Foxo1, Hif3a, Klf15, Nr4a1, Nr4a2, } \\
\text { Pcgf6, Sox10, Sox2, Tsc22d3, Uncx, Zbtb16, Znfx1, Zscan21 }\end{array}$ \\
\hline & Protein kinase activity & 9.46 & 3.83 & 0.02117 & Erbb3, Fgfr2, Map3k6, Mast3, Mertk, Pdk4, Sgk1, Sgk3, Tek, Trib2 \\
\hline \multirow[t]{2}{*}{ Cellular component } & Cytosol & 14.19 & 5.38 & 0.00147 & $\begin{array}{l}\text { Cdkn1a, Errfi1, Foxo1, Gnmt, Stxbp3a, Nfkbia, Pnpla2, Psmf1, Sdpr, } \\
\text { Tgm2, Xdh, Zbtb16, Zfp36 }\end{array}$ \\
\hline & Extracellular region part & 10.81 & 5.09 & 0.04128 & $\begin{array}{l}\text { Ada, Adamts4, Angpt14, Cmtm3, Col4a1, Ctgf, Cxcl12, Erbb3, Pglyrp1, } \\
\text { Tgm2, Thbd }\end{array}$ \\
\hline \multirow[t]{5}{*}{ Biological process } & Response to stress & 22.3 & 9.34 & 0.00011 & $\begin{array}{l}\text { Ada, Angptl4, Cdkn1a, Cirbp, Cxcl12, Ddit4, Dio2, Erbb3, Errfi1, Fos, } \\
\text { Gab1, Hif3a, Hmgb2, Kcna5, Nr4a2, Pglyrp1, Serpinh1, Sfpq, Sgk1, } \\
\text { Slc2a1, Sult1a1, Thbd, Trp53inp1, Tsc22d3, Txnip, Ucp2, Xpa }\end{array}$ \\
\hline & Regulation of transcription, DNA-dependent & 20.95 & 8.99 & 0.00031 & $\begin{array}{l}\text { Aff1, Carhsp1, Cebpd, Crebzf, Eomes, Fos, Foxo1, Fus, Hif3a, Hmgb2 } \\
\text { Hr, Klf15, Nfkbia, Nr4a1, Nr4a2, Pcgf6, Sdpr, Sox10, Sox2, Tsc22d3, } \\
\text { Txnip, Uncx, Zbtb16, Zfp810, Znfx1, Zscan21 }\end{array}$ \\
\hline & Regulation of apoptosis & 16.89 & 5.03 & 0.00001 & \begin{tabular}{|l|} 
Ada, Angptl4, Cdkn1a, Cx3cr1, Erbb3, Foxo1, Nr4a1, Nr4a2, Sgk3, \\
Tgm2, Trp53inp1, Tsc22d3, Txnip, Xpa, Zbtb16
\end{tabular} \\
\hline & TM receptor protein tyrosine kinase signaling pathway & 8.78 & 1.52 & 0.00002 & Ctgf, Erbb3, Fgfr2, Foxo1, Gab1, Sh2b2, Tek, Txnip \\
\hline & Response to oxidative stress & 4.73 & 1.07 & 0.01093 & Ada, Fos, Gab1, Txnip, Ucp2, Xpa \\
\hline
\end{tabular}


Table S12. GO terms enrichment in genotype-dependent PQ-regulated genes

\begin{tabular}{|c|c|c|c|c|c|}
\hline & GO terms & Array \% & Genome \% & $P$ value & Genes \\
\hline \multirow[t]{2}{*}{ Molecular function } & Metal ion binding & 31.65 & 9.69 & 0.000002 & $\begin{array}{l}\text { Eif2c2, Adcy8, Znfx1, Tiparp, Kcna5, Rhou, Aspa, Zscan21, Pcgf6, Kcne2, Bcl6, } \\
\text { Zfp810, Thbs3, Zfp36, Klf7, Adssl1, Lpp, Runx1t1, Klf15, Prkcd, Mast3, Xpa, } \\
\text { Slc25a13, Fbln5, Heph, Cpd, Steap1, Cdh11 }\end{array}$ \\
\hline & Nucleic acid binding & 26.58 & 7.4 & 0.000005 & $\begin{array}{l}\text { Zfp36, Sox10, Klf7, Hmgb2, Cebpb, Crebzf, Znfx1, Sox2, Eomes, Runx1t1, Sox4, } \\
\text { Klf15, Aff1, Chrac1, Xpa, Zscan21, Smarcc1, Sfpq, Bcl6 }\end{array}$ \\
\hline \multirow[t]{2}{*}{ Cellular component } & Nucleus & 35.44 & 13.61 & 0.0000232 & $\begin{array}{l}\text { Eif2c2, Hmgb2, Sox2, Sox4, Aspa, Zscan21, Pcgf6, Bcl6, Zfp810, Phlda1, Zfp36, } \\
\text { Sox10, Klf7, Cebpb, Crebzf, Lpp, Runx1t1, Eomes, Tle1, Klf15, Aff1, Chrac1, Xpa, } \\
\text { Smarcc1, Sfpq }\end{array}$ \\
\hline & Membrane & 21.52 & 9.68 & 0.0107568 & $\begin{array}{l}\text { Lrrc33, Lrrc8a, Adcy8, Cldn5, Kcna5, Rhou, Rell1, Cd44, Sdpr, Tek, Slco1c1, } \\
\text { Kcne2, Elovl7, Lfng, Piga, Phlda1, Vasn, Tyro3, Spns2, Adssl1, Ugt8a, Efnb2, } \\
\text { Adipor2, Prkcd, Rab31, SIc25a13, Sema6d, Dio2, Heph, Cpd, Steap1, Cdh11 }\end{array}$ \\
\hline \multirow[t]{3}{*}{ Biological process } & Nervous system development & 20.25 & 3.16 & 0.0000001 & $\begin{array}{l}\text { Adcy8, Cd44, Cdh11, Cebpb, Cldn5, Col4a1, Dio2, Efnb2, Elavl3, Eomes, Gas7, } \\
\text { Hmgb2, Klf7, Lfng, Piga, Prkcd, Sema6d, Serpinh1, Smarcc1, Sox2, Sox4, Sox10, } \\
\text { Tnc, Xpa, Zscan21 }\end{array}$ \\
\hline & Regulation of transcription & 22.78 & 6.5 & 0.0000551 & $\begin{array}{l}\text { Sox10, Klf7, Hmgb2, Cebpb, Crebzf, Znfx1, Sox2, Eomes, Runx1t1, Sox4, Tle1, } \\
\text { Klf15, Aff1, Zscan21, Sdpr, Pcgf6, Bcl6, Zfp810 }\end{array}$ \\
\hline & Response to stress & 18.99 & 4.33 & 0.00003 & $\begin{array}{l}\text { Bcat1, Bcl6, Cd44, Ddit4, Errfi1, Hmgb2, Hspa1b, Hspa8, Prkcd, Serpinh1, Sfpq, } \\
\text { Sox4, Tyro3, Xpa }\end{array}$ \\
\hline
\end{tabular}




\subsection{A Apolipoprotein D mediates autocrine protection of astrocytes and controls their reactivity level, contributing to the functional maintenance of paraquat-challenged dopaminergic systems (Objective 2).}

This objective aimed at determining how ApoD expression is controlled in response to oxidative stress in one of the cell types that produces ApoD in the nervous system (astrocytes). We question whether its expression contributes to the high levels of resistance and reactivity of these glial cells, and how this contributes to the maintenance of dopaminergic systems in situations of oxidative stress.

The results for this objective are contained in the publication

- Bajo-Grañeras, Ganfornina MD, Martín-Tejedor E, Sanchez D

- Apolipoprotein $D$ mediates autocrine protection of astrocytes and controls their reactivity level, contributing to the functional maintenance of paraquat-challenged dopaminergic systems - Glia2011 Oct;59(10):1551-66

attached below.

This publication has been awarded the "I Premio Laia Acarín to Young Investigators" by the Spanish GLIA Network. The award includes the invitation to present this work as Invited Speaker in the Workshop "Frontiers in Glial Research", a satellite symposium in the FENS 2012 meeting, next 13 of July of 2012. 



\subsection{B Protección autocrina de ApoD sobre astrocitos, su nivel de reactividad y su contribución al mantenimiento de los sistemas dopaminérgicos al estrés oxidativo (Objetivo 2).}

Este objetivo consistía en determinar cómo se controla la expresión de ApoD en respuesta al estrés oxidativo en uno de los tipos celulares más productores de ApoD en el sistema nervioso (los astrocitos), y cuestionar si su expresión contribuye a mejorar la resistencia de estas células gliales, su nivel de reactividad y su contribución al mantenimiento de los sistemas dopaminérgicos frente al estrés oxidativo.

Los resultados relativos a este objetivo están contenidos en la publicación

- Bajo-Grañeras, Ganfornina MD, Martín-Tejedor E, Sanchez D

- Apolipoprotein $D$ mediates autocrine protection of astrocytes

and controls their reactivity level, contributing to the functional maintenance of paraquat-challenged dopaminergic systems

- Glia2011 Oct;59(10):1551-66

que se adjunta a continuación.

Esta publicación ha sido galardonada con el "I Premio Laia Acarín para Jóvenes Investigadores" otorgado por la Red Glial Española. El premio incluye la invitación para presenter este trabajo como Conferenciante Invitado en el Workshop "Frontiers in Glial Research", un simposio satélite del congreso FENS 2012, a celebrar el próximo 13 de Julio de 2012.

En esta sección hemos estudiado la función de ApoD en el cerebro de ratón, comparando ratones silvestres con ratones con pérdida de función (ApoD$\mathrm{KO}$ ) y combinando experimentos in vivo con cultivos primarios de astrocitos. Hemos medido el comportamiento locomotor de los individuos, las concentraciones de dopamina en el cerebro y los niveles de expresión génica 
en la sustancia negra de ratones tratados con PQ. En cultivos primarios de astrocitos hemos analizado las vías de señalización que controlan la expresión de ApoD ante el estrés oxidativo, y los cambios en el perfil transcripcional de un conjunto de genes relacionados con el estrés oxidativo. Hemos cuantificado la viabilidad celular, los niveles de peroxidación lipídica y los efectos que tiene añadir ApoD humana a cultivos de astrocitos.

Los resultados obtenidos nos indican que ApoD es necesaria para el correcto funcionamiento del sistema dopaminérgico nigroestriatal ante un daño provocado por $\mathrm{PQ}$. Es requerida para mantener una adecuada locomoción y el perfil de expresión de genes relacionados con la respuesta a estrés oxidativo. Además hemos comprobado que ApoD es regulado por la vía de JNK en respuesta al estrés oxidativo y que contribuye a la protección autocrina de los astrocitos, modulando la respuesta transcripcional al estrés y evitando la acumulación de lípidos peroxidados. Por último hemos comprobado que la adición de ApoD humana contribuye a mejorar la resistencia de los astrocitos y a disminuir sus niveles de reactividad tanto in vitro como in vivo.

Por todo ello, podemos concluir que ApoD funciona como factor de mantenimiento para los astrocitos que este efecto es suficiente para explicar los niveles de protección que hemos obtenido in vivo para un circuito vulnerable a estrés oxidativo como es el dopaminérgico. 


\title{
Apolipoprotein D Mediates Autocrine Protection of Astrocytes and Controls Their Reactivity Level, Contributing to the Functional Maintenance of Paraquat-Challenged Dopaminergic Systems
}

\author{
RAQUEL BAJO-GRAÑERAS, MARIA D. GANFORNINA, ESPERANZA MARTÍN-TEJEDOR, AND DIEGO SANCHEZ* \\ Instituto de Biología y Genética Molecular-Departamento de Bioquímica y Biología Molecular y Fisiología, \\ Universidad de Valladolid-CSIC, Valladolid, Spain
}

\section{KEY WORDS}

lipocalin; oxidative stress; nigrostriatal system

\begin{abstract}
The study of glial derived factors induced by injury and degeneration is important to understand the nervous system response to deteriorating conditions. We focus on Apolipoprotein D (ApoD), a Lipocalin expressed by glia and strongly induced upon aging, injury or neurodegeneration. Here we study ApoD function in the brain of wild type and ApoD-KO mice by combining in vivo experiments with astrocyte cultures. Locomotor performance, dopamine concentration, and gene expression levels in the substantia nigra were assayed in mice treated with paraquat $(P Q)$. The regulation of $\mathrm{ApoD}$ transcription, a molecular screening of oxidative stress (OS)-related genes, cell viability and oxidation status, and the effects of adding human ApoD were tested in astrocyte cultures. We demonstrate that (1) ApoD is required for an adequate locomotor performance, modifies the gene expression profile of $\mathrm{PQ}$-challenged nigrostriatal system, and contributes to its functional maintenance; (2) ApoD expression in astrocytes is controlled by the OSresponsive JNK pathway; (3) ApoD contributes to an autocrine protecting mechanism in astrocytes, avoiding peroxidated lipids accumulation and altering the PQ transcriptional response of genes involved in ROS managing and the inflammatory response to OS; (4) Addition of human ApoD to ApoD-KO astrocytes promotes survival through a mechanism accompanied by protein internalization and modulation of astroglial reactivity. Our data support that ApoD contributes to the endurance of astrocytes and decreases their reactivity level in vitro and in vivo. ApoD function as a maintenance factor for astrocytes would suffice to explain the observed protection by ApoD of OS-vulnerable dopaminergic circuits in vivo. $\odot 2011$ Wiley-Liss, Inc.
\end{abstract}

\section{INTRODUCTION}

The roles of astrocytes in a healthy central nervous system (CNS) are many and diverse. The already complex known functions of astrocytes, including metabolic support for neurons, local control of blood flow, regulation of extracellular ions and neurotransmitter concentration, have recently been expanded by the discovery of their participation in synaptic information processing and plasticity (Perea et al., 2009). This versatile cell is, in addition, the most resilient cell in the CNS. Astrocytes are particularly durable when our brain ages (Liddell et al., 2010), and are extremely resistant to the many forms of stress that occur when the CNS succumbs to disease. Astrocytes respond to CNS disease by a phenotypic transformation known as reactive astrogliosis, which involves a reorganization of their gene expression leading to a profound change in morphology and in migratory and proliferative capacities (Pekny and Nilsson 2005). Astrocyte reactivity can be considered a double-edged sword: triggered as a protection mechanism can become dangerous if out of control. We are starting to comprehend many of the molecular signals and processes that turn-on astrocyte reactivity (Sofroniew, 2009). However, the knowledge of mechanisms that restrain the extent of astrogliosis and control its resolution is scarce and fragmentary. The importance of turn-off mechanisms is highlighted by the fact that many pathological situations are caused by defects in processes that must stop glial reactivity.

Oxidative stress (OS), a phenomenon concomitant to most forms of CNS damage and neurodegeneration, is well known to trigger astrocyte reactivity. Oxidative insults are of special concern for dopaminergic systems, since dopamine (DA) metabolism inevitably results in high levels of reactive oxygen species (ROS) that have to be counteracted locally by antioxidant mechanisms (Miller et al., 2009). Astrocytes are therefore clear candidates to play an important role not only in the maintenance of dopaminergic systems in the healthy brain, but also in the brain affected by Parkinson's disease (PD), a progressive degenerative disorder primarily characterized by the selective loss of dopaminergic neurons in the substantia nigra (SN). The astroglial response is being studied deeply in PD patients and animal models of PD

Grant sponsor: MEC; Grant number: BFU2005-00522; Grant sponsor: JCyL; Grant numsor: MEC; Grant number: BFU2005-00522; Grant sponsor: JCyL; 01170; Grant sponsor: JCyL; Grant number: GRS/278/A/08.

*Correspondence to: Diego Sánchez, Instituto de Biología y Genética Molecular, c/ Sanz y Forés 3, Universidad de Valladolid-CSIC, 47003 Valladolid, Spain.

E-mail: lazarill@ibgm.uva.es

Received 27 December 2010; Accepted 23 May 2011

DOI 10.1002/glia.21200

Published online 17 June 2011 in Wiley Online Library (wileyonlinelibrary.com). 
(Morale et al., 2006; Song et al., 2009), but we are still far from understanding it.

Apolipoprotein D (ApoD), a member of the Lipocalin family secreted by astrocytes and oligodendrocytes, but not expressed in microglia, is known to mediate protective effects for the organism under OS (Ganfornina et al., 2008). The homologues of ApoD in Drosophila, GLaz and NLaz, protect against oxidative damage and contribute significantly to the regulation of longevity (HullThompson et al., 2009; Ruiz et al., 2011; Sanchez et al., 2006; Walker et al., 2006). ApoD is in fact the most robust age dependent up-regulated gene in the brain, conserved across species (de Magalhaes et al., 2009; Loerch et al., 2008), and its expression is boosted by a collection of traumatic, pathological and degenerative nervous system conditions in humans (reviewed by Van Dijk et al., 2006), including Parkinson's disease (Ordonez et al., 2006; Song et al., 2009).

In this work we assay ApoD contribution to the ability of astrocytes to perform protective functions. Our work has three main objectives: (i) to understand how ApoD expression is controlled in the context of the glial response to oxidative insults, (ii) to ascertain whether ApoD contributes to the endurance of astrocytes, therefore potentially contributing to their functional maintenance through aging and disease, and (iii) to test whether ApoD has an impact on the vulnerability of dopaminergic neurons and their functional performance. We use glial cell cultures (primary cortical astrocytes derived from wild type or ApoD-KO mice and human cell lines) as well as mice treated with paraquat (PQ) as our experimental paradigms.

We have tested whether ApoD null mutant mice have alterations in dopaminergic systems by evaluating locomotor performance, dopamine content, and the molecular response to OS in the substantia nigra. We have assayed whether the stress-activated JNK pathway controls ApoD expression in astrocytes, and how ApoD influences glial viability, their reactivity in vivo and in vitro, and their transcriptional response upon increased OS. Finally, we have tested the ability of exogenous ApoD to improve $\mathrm{PQ}$-challenged astrocyte viability.

\section{MATERIALS AND METHODS Animals}

Wild type (WT) and loss-of-function mutants for ApoD (ApoD-KO) mice were bred at the University of Valladolid animal facility. Genotyping was performed by PCR as previously described (Ganfornina et al., 2008). Mice were fed standard rodent chow and water ad libitum in ventilation-controlled cages in a 12-h light/dark cycle. Experimental cohorts used in this study are the F1 generation of homozygous crosses of ApoD-/- and ApoD+/ + littermates born from heterozygous crosses of the ApoD-KO line in C57BL/6J background. This strategy avoids potential maternal effects of $\mathrm{ApoD}$ and generates WT and ApoD-KO cohorts with homogeneous genetic background.
Experimental procedures were approved by the University of Valladolid Animal Care and Use Committee in accordance with the Guidelines for the Care and Use of Mammals in Research (European Commission Directive 86/609/CEE, Spanish Royal Decree 1201/2005).

\section{PQ and LPS Treatments}

Male mice (eight-month-old, $N=6$ 6/genotype for $\mathrm{PQ}$ and $N=4$ /genotype for carrier) were injected intraperitoneally with either $10 \mathrm{mg} \mathrm{kg}^{-1} \mathrm{PQ}$ or PBS for a total of seven injections (twice a week for the first two weeks, one per week for three additional weeks) and used for locomotor activity tests, dopamine measures, immunoblot, and qRT-PCR analyses. Open field behavioral tests were performed six days after the last injection, and tissues were obtained seven days after the last injection. A second cohort (seven-month-old males, $N=4$ /genotype for $\mathrm{PQ}$ and $N=2$ /genotype for carrier) was used for immunohistochemistry after the same protocol of $\mathrm{PQ}$ injections.

Two seven-month-old WT male mice, injected with a single dose of $30 \mathrm{mg} \mathrm{kg}{ }^{-1} \mathrm{PQ}$ or $3.3 \mathrm{mg} \mathrm{kg}^{-1}$ LPS for $12 \mathrm{~h}$, were used as controls for acute effects of oxidative and proinflammatory stimuli.

\section{Locomotor Activity}

Open field tests were carried out with a MIR-100 infrared digital camera and the Activity Monitor (v. 5.0) acquisition and analysis program (Med Associates). Mice locomotor behavior was explored during a 5 min session.

\section{HPLC Determination of Dopamine and Its Catabolites}

Dopamine (DA) and its catabolites (4-dihydroxy-phenylacetic acid, DOPAC, and homovanillic acid, HVA) were measured in the brain portion anterior to the substantia nigra. Brain tissue was homogenized in $0.1 \mathrm{~N}$ perchloric acid, $0.1 \mathrm{mM}$ EDTA, and centrifuged $(8 \mathrm{~min}$, $1000 \mathrm{~g})$. Supernatants $(50-\mu \mathrm{L}$ aliquots) were injected into an HPLC system equipped with a Phenomenex Gemini 5 C18 (particle size $5 \mu \mathrm{m}$ ) column (mobile phase: $\mathrm{Na}_{2} \mathrm{HPO}_{4} 25 \mathrm{mM}$, sodium octane sulphonate $0.6 \mathrm{mM}$, EDTA $0.1 \mathrm{mM}, 10 \%$ methanol, pH 4.35). DA, DOPAC, and HVA concentrations, expressed as $\mathrm{pmol} / \mathrm{mg}$ of tissue, were estimated using reference standards (Sigma).

\section{Immunocytochemistry}

Cells attached to poly-L-lysine treated coverslips were fixed with $4 \%$ formaldehyde in PBS. Following washes in PBS, blocking and permeabilization (TritonX-100 $0.25 \%$ in PBS, $1 \%$ normal goat serum), cells were incubated with either rabbit serum anti-GFAP (Dako, 
Denmark) or rabbit serum anti-hApoD (generated by C. López-Otín). Cy3 or Cy2-conjugated goat anti-rabbit IgG (Abcam, UK) were used as secondary antibodies for fluorescence immunocytochemistry. After washes in PBS, preparations were mounted with Vectashield-DAPI (Vector Labs). Labeled cells were visualized with an Eclipse 90i (Nikon) fluorescence microscope equipped with a DS-Ri1 (Nikon) digital camera. Images were acquired under the same conditions of illumination, diaphragm and condenser adjustments, exposure time, background correction and color levels, and processed with NIS-Elements BR 3.0 software (Nikon) for fluorescence quantification. A minimum of five 20x fields were quantified.

Confocal images were obtained in a DMI 6000B microscope with a TCS SP5 X confocal system and a WLL laser (Leica) controlled by LAS AF software (Leica).

\section{Immunohistochemistry}

Mouse brains were quickly removed and midbrains cut horizontally in $200-\mu \mathrm{m}$ sections on a vibratome (Microm). Slices were fixed in $4 \%$ paraformaldehyde for $3 \mathrm{~h}$ at room temperature, washed, and blocked for $2 \mathrm{~h}$ (in $0.5 \%$ triton $\mathrm{X}-100,1 \%$ normal goat serum) before overnight incubation at $4^{\circ} \mathrm{C}$ with either mouse serum anti-tyrosine hydroxylase (TH) (Sigma) or rabbit serum anti-GFAP (Dako, Denmark) antibodies. Following extensive washes with PBS, slices were incubated with secondary antibody (Goat anti-mouse Cy3 or anti-rabbit Alexa 488 (Santa Cruz, CA)) for $2 \mathrm{~h}$ at room temperature. Labeled cells were visualized in an Eclipse 90i (Nikon) as described above.

TH-positive cells from the SN pars compacta (SNc) were counted in the areas described by McCormack et al. (2002) in seven slices per mouse (Fig. S1). GFAP fluorescence quantification was performed in the same slices (see Fig. S1 for the areas selected) as described above in the immunocytochemistry section.

\section{Immunoblot Analysis}

Brain tissue, either from SN or from striatum, was homogenized in lysis buffer (1\% Nonidet P-40, 0.1\% SDS, $10 \%$ Glycerol, $1 \%$ sodium deoxycholate, $1 \mathrm{mM}$ Dithiothreitol, $1 \mathrm{mM}$ EDTA, $100 \mathrm{mM}$ HEPES, $100 \mathrm{mM} \mathrm{KCl}$, 10\% Complete Protease Inhibitors (Roche) in PBS), centrifuged after $30 \mathrm{~min}$ at $4^{\circ} \mathrm{C}$, and the supernatant stored at $-80^{\circ} \mathrm{C}$. Cultured cells were lysed in the same buffer.

Protein concentration was determined with Micro$\mathrm{BCA}^{\mathrm{TM}}$ protein assay (Pierce). Immunoblot analyses were performed with $10-20 \mu \mathrm{g}$ of total protein/lane transferred to PVDF membranes using standard procedures. We used the following primary antibodies: Rabbit serum anti-GFAP (Dako, Denmark); Rabbit serum antihApoD (generated by C. López-Otín); Rabbit anti-Sod2 (Santa Cruz, CA); Goat anti-HO-1 (Santa Cruz, CA); and Goat serum anti-mApoD (Santa Cruz, CA). Secondary
HRP-conjugated Goat anti-Rabbit or Donkey anti-goat IgG (Santa Cruz, CA) were used. Each blot was also incubated with HRP-conjugated anti- $\beta$ actin antibody (Sigma) for normalization purposes. Membranes were developed with ECL (Millipore) and the integrated optical density of the immunoreactive protein bands was measured in images taken within the linear range of the camera (VersaDoc, BioRad) avoiding signal saturation. Mean \pm SD of arbitrary density units was calculated from at least duplicate blots.

\section{Cell Cultures}

Primary cortical glial cultures. The cerebral cortices of neonatal (P0) mice were quickly extracted. The meninges were removed by rolling on a sterile filter paper, and pieces of cortex were placed in Earle's Balanced Salt Solution (EBSS) containing $2.4 \mathrm{mg} \mathrm{mL}^{-1}$ DNAse I and $0.2 \mathrm{mg} \mathrm{mL}^{-1}$ bovine serum albumin. The tissue was minced with a surgical blade, centrifuged (200g, $2 \mathrm{~min}$ ), incubated with $10 \mathrm{mg} \mathrm{mL}{ }^{-1}$ trypsin for $15 \mathrm{~min}$ at $37^{\circ} \mathrm{C}$ (incubation terminated by addition of $10 \%$ FBS), mechanically dissociated with a Pasteur pipette, and centrifuged $(200 \mathrm{~g}, 5 \mathrm{~min})$. The last two steps were repeated, and the resulting cells were resuspended in Dulbecco's Modified Eagle's medium (DMEM) with $10 \%$ FBS, 1\% L-Gln, 1\% P/S/A (Penicillin (10U/ $\mu \mathrm{L})$-Streptomycin $(10 \mu \mathrm{g} / \mu \mathrm{l})$-Amphotericyn B $(25 \mu \mathrm{g} / \mathrm{mL}))$. Cells were plated onto culture flasks and incubated at $37^{\circ} \mathrm{C}$ in $5 \% \quad \mathrm{CO}_{2}$ with 90-95\% humidity. Medium was weekly replaced. After two to three subculture steps, over $95 \%$ of Type 1 astrocytes were present, as estimated by GFAP labeling and by morphological criteria. Cultures had a minor contribution of microglial cells, but oligodendrocytes were not detected.

The cell lines 1321N1, HeLa, and HEK were grown and maintained in DMEM with 5\% FBS, 1\% L-Gln and $1 \% \mathrm{P} / \mathrm{S} / \mathrm{A}$ at $37^{\circ} \mathrm{C}$ in $5 \% \mathrm{CO}_{2}$ with $90-95 \%$ humidity.

\section{Quantitative RT-PCR}

RNA from homogenized mesencephalic fragments or cultured cells were extracted with TRIzol (Invitrogen). Total RNA $(1 \mu \mathrm{g})$ was reverse-transcribed with PrimeScript $^{\text {TM }}$ (Takara) and treated with DNaseI. The cDNA obtained was used as template for qRT-PCR amplifications. We used TaqMan probes for the genes Gdnf, Alox15, Nos2, Il6, Tnfa, Mbp, and ApoE (Primers and probes designed by Roche Applied Science; Universal ProbeLibray). To amplify mouse and human ApoD we used SYBR Green I (Takara) and the following primers. Mouse Rpl18-Forward: 5'-TTCCGTCTTTCCG GACCT; Mouse Rpl18-Reverse: 5'-TCGGCTCATGAACA ACCTCT; Mouse ApoD-Forward: 5'-GAAGCCAAACAG AGCAACG; Mouse ApoD-Reverse: 5'-TGTTTCTGGAGG GAGATAAG GA; Human PL18-Forward: CCATCATGG GAGTGGAC AT; Human PL18-Reverse: 5'-CACGGCC GTCTTGTTT TC; Human ApoD-Forward: 5'- CCACCC 
CAGTTAACCT CACA; Human ApoD-Reverse: 5'CCACTGTTTCTGGAGGGAGA. Rpl18 was used as the reference gene because neither genotype nor treatment gives a significant fold change for this gene.

To study genes related to the antioxidant response and ROS metabolism, we used SYBR Green and the qRT-PCR array PMM-065A (SABiosciences). Gapdh was selected as reference gene. Amplifications were performed in quadruplicate in an ABI Prism 7900HT or a Rotor-Gene RG-3000 (Corbett Research) thermal cycler. Standard cycling conditions were: $95^{\circ} \mathrm{C}, 5 \mathrm{~min} ; 40 \times$ $\left(95^{\circ} \mathrm{C}, 30 \mathrm{~s} ; 60^{\circ} \mathrm{C}, 1 \mathrm{~min}\right)$.

Changes in transcriptional expression were estimated with the $\Delta \Delta C_{\mathrm{T}}$ method (Livak and Schmittgen, 2001). The following criteria were applied to our analysis: (1) Replicates with variation coefficient $>2.5 \%$ were excluded. (2) Undetermined $C_{\mathrm{T}}$ values (gene expression below detection levels) were assigned $C_{\mathrm{T}}=35$. Pairwise comparisons where the gene average $C_{\mathrm{T}}>35$ cycles in both conditions were excluded from the analysis. (3) Only transcriptional changes $\geq$ twofold were included in the analysis. Significant differences of gene transcriptional changes were evaluated with a Mann-Whitney $U$ test, using $\Delta C_{\mathrm{T}}$ of each replica. Values are expressed as mean \pm SEM. Only statistically significant $(P<0.05)$ differences of expression are presented and discussed in the text.

\section{Viability Assay}

Astrocyte viability was measured by the extent of 3(4,5-Dimethylthiazol-2-yl)-2,5-diphenyltetrazolium bromide (MTT; Sigma) reduction to insoluble intracellular formazan (dependent on the activity of intracellular dehydrogenases). Cultures were incubated with MTT (5 $\mathrm{mg} / \mathrm{ml}$ in PBS) for $3 \mathrm{~h}$ at $37^{\circ} \mathrm{C}$. An equal volume of solubilization buffer (2-Propanol 0.04; $0.1 \mathrm{~N} \mathrm{HCl} ; 10 \%$ TritonX-100) was added and mixed thoroughly to dissolve the formazan crystals. MTT reduction was measured spectrophotometrically by subtracting background at $690 \mathrm{~nm}$ from the absorbance at $570 \mathrm{~nm}$ and expressed as \% control.

\section{Apoptosis Assays}

\section{Flow-cytometry analysis}

Cells were treated with trypsin-EDTA, washed with PBS, resuspended in $100 \mu \mathrm{L}$ Annexin V binding buffer, and incubated with $4 \mu \mathrm{L}$ of FITC-conjugated Annexin V and $4 \mu \mathrm{L}$ propidium iodide (PI) according to the manufacturer's specifications (Immunostep). Cells were incubated for $30 \mathrm{~min}$ at room temperature in the dark and diluted with $400 \mu \mathrm{L}$ of Annexin $\mathrm{V}$ binding buffer just before injection into a flow cytometer (Gallios; Beckman Coulter). Data were analyzed with the Kaluza software (v1.1; Beckman Coulter).
TUNEL labeling kit (Roche) was used to assay apoptotic cell death both in mesencephalic tissue sections and in primary glial cell cultures. Immunolabeled cells were observed with a Nikon (Eclipse 80i) microscope and a DS-Ri1 digital camera. Images were acquired and processed with the NIS-Elements BR 3.0 software (Nikon).

\section{Biochemical Assays}

\section{TBARS assay}

Brain tissue was homogenized in PBS in the presence of butylated hydroxytoluene (BHT). Extracts were incubated with $0.2 \mathrm{M}$ glycine-HCl, $\mathrm{pH} 3.6$ and TBA reagent $(0.5 \% \mathrm{TBA}, 0.5 \% \mathrm{SDS})$. After $15 \mathrm{~min}$ incubation at $90^{\circ} \mathrm{C}$, samples were cooled on ice and transferred to a 96-well microplate for triplicate readings. Absorbance was monitored at $532 \mathrm{~nm}$ in a Versamax microplate reader (Molecular Devices).

Malondialdehyde concentration (MDA-586 assay, Bioxytech), and aconitase activity (Aconitase-340 assay, Bioxytech) were measured following the manufacturer's recommendations.

In all these assays the experimental values were normalized to protein concentration, measured with the Micro BCA Protein Assay (Pierce). At least two independent experiments with measurements in triplicate were performed.

\section{Statistical Analysis}

Statistical analyses were performed with Statgraphics plus (v 5.0) software. $P<0.05$ was defined as a threshold for significant changes.

\section{RESULTS \\ ApoD-KO Mice Show Alterations in the Dopaminergic System Associated with Bradykinesia upon Chronic Paraquat Treatment}

We have previously demonstrated that ApoD confers protection at the organism level, promoting survival and preventing brain tissue oxidation upon different paradigms of $\mathrm{PQ}$ intraperitoneal injections (Ganfornina et al., 2008). Moreover, ApoD contributes to the early response to OS, as it is transiently up-regulated in the brain of mice acutely exposed to PQ (Ganfornina et al., 2008). This study was designed to examine whether ApoD has protective potential for the nigrostriatal dopaminergic system, a neuronal circuit particularly vulnerable to OS and markedly sensitive to PQ toxicity. PQ and other neurotoxicants have been used as chemical models of Parkinson's disease. We used a paradigm of PQ injections (see Methods) that generates a mild OS and slow PQ accumulation in the brain (Prasad et al., 2009), but not systemically (Prasad et al., 2007). With this low-dose chronic PQ exposure, ApoD mRNA levels in the WT 


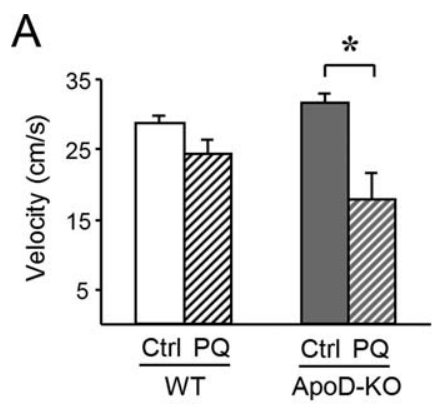

Open field behavioral analysis

B

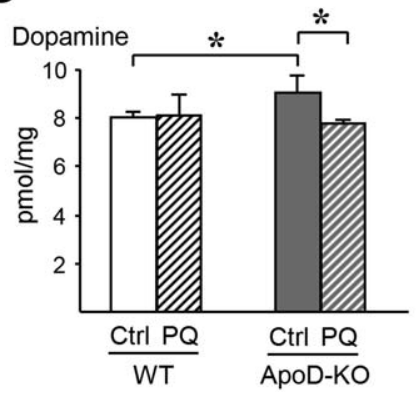

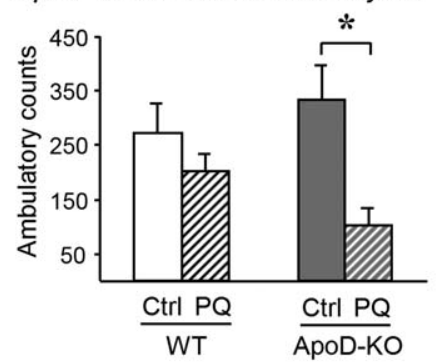

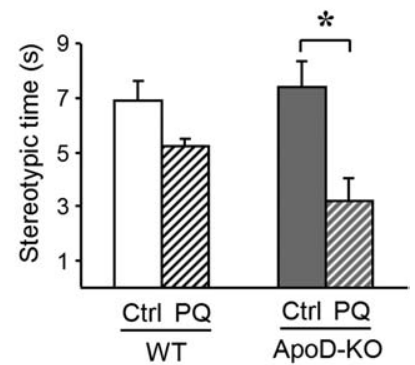

Dopamine metabolism analysis (HPLC)

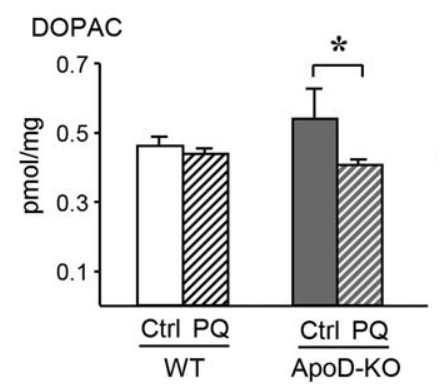

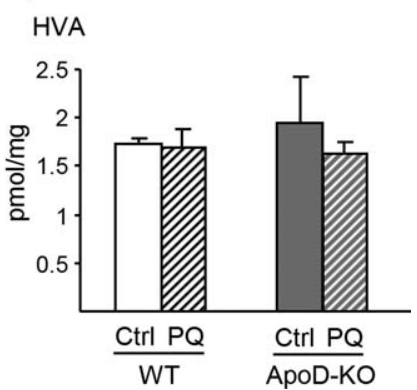

Fig. 1. Lack of ApoD alters the nigrostriatal dopaminergic system and results in bradykinesia upon chronic PQ treatment. A: Open field test of locomotor exploratory behavior performed 6 days after the 7th $\mathrm{PQ}$ injection (10 $\mathrm{mg} \mathrm{kg}^{-1}$ ). While this mild chronic exposure to $\mathrm{PQ}$ does not alter locomotor output in WT controls, the velocity of movement, number of ambulatory events and time spent in stereotypic movements

substantia nigra (SN), measured seven days after the last injection, do not differ from control sham-injected mice (Fig. S2A), revealing that the induction of ApoD mRNA expression has already resolved and returned to basal levels by the end of the treatment. However, as expected from the stability of the Lipocalin fold, ApoD protein is maintained at slightly higher levels than the control samples after this chronic PQ treatment (Fig. $\mathrm{S} 2 \mathrm{~B})$. Therefore, the genotype-dependent changes we describe below will be the consequence of the absence of transient peaks of ApoD expression after each PQ injection (as revealed by the acute treatments used as positive controls in Fig. S2B), and of the constant mild increase of this stable extracellular protein.

As expected for this low-dose chronic PQ treatment, no significant differences in open field activity are observed in WT mice six days after the 7th PQ dose (Fig. 1A). However, ApoD-KO mice show a significant PQ-dependent decrease in locomotor activity (bradykinesia), demonstrating that without ApoD the functional circuits controlling motor outputs become more vulnerable to the long-term effects of $\mathrm{PQ}$.

To analyze the functional state of dopaminergic systems, brains were studied seven days after the 7th PQ dose. It is known that alterations in DA levels in the striatum of WT animals require 12-18 doses of $10 \mathrm{mg}$ $\mathrm{kg}^{-1}$ PQ (Prasad et al., 2009; Thiruchelvam et al., 2000), or combinations of PQ with MPTP or Maneb (Shepherd et al., 2006; Thiruchelvam et al., 2000). In our study, neither DA nor its metabolites change in the WT cohort after the 7th dose. In contrast, the ApoD-KO are significantly decreased in ApoD-KO mice. B: The concentration of anterior brain DA and its metabolites (DOPAC and HVA) was determined by HPLC seven days after the 7th PQ injection. DA and DOPAC were reduced upon $\mathrm{PQ}$ treatment only in ApoD-KO mice. A genotype-dependent basal increase in DA was also observed. Data shown as mean \pm SD. $N=10$ mice/genotype. Unpaired Student's $t$-test; $* P<0.05$.

mice show statistically significant PQ-dependent changes, revealing a lower amount of both DA and DOPAC (Fig. 1B). Our data suggest that the $\mathrm{PQ}$ regime used causes dopaminergic neurons to be impaired only in the ApoD-KO mice.

To test if these alterations are due to a higher dopaminergic cell death in ApoD-KO mice, we counted the number of $\mathrm{TH}$-positive cells in the $\mathrm{SN}$ pars compacta (SNc). As previously reported (McCormack et al., 2002), a decrease in the number of TH-positive neurons upon $\mathrm{PQ}$ treatment is evident, both in WT and ApoD-KO mice (Fig. 2A,B). However, no differential cell death is observed between the two genotypes. Also, no TUNELpositive cells were observed following the chronic PQ treatment (not shown).

These results suggest that functional alterations in the PQ-vulnerable SNc neurons, instead of a higher rate of cell death, are the major consequence of the lack of ApoD when mice are exposed to our chronic PQ protocol, leading to the behavioral malfunction and the dopamine alterations observed.

\section{Markers of Glial Reactivity and Antioxidant Response Change in the Substantia Nigra in the Absence of ApoD}

To further understand the functional consequences of ApoD absence in the nigrostriatal dopaminergic system, we evaluated the level of mRNA or protein expression of a set of genes (Fig. 3) in mesencephalic extracts includ- 

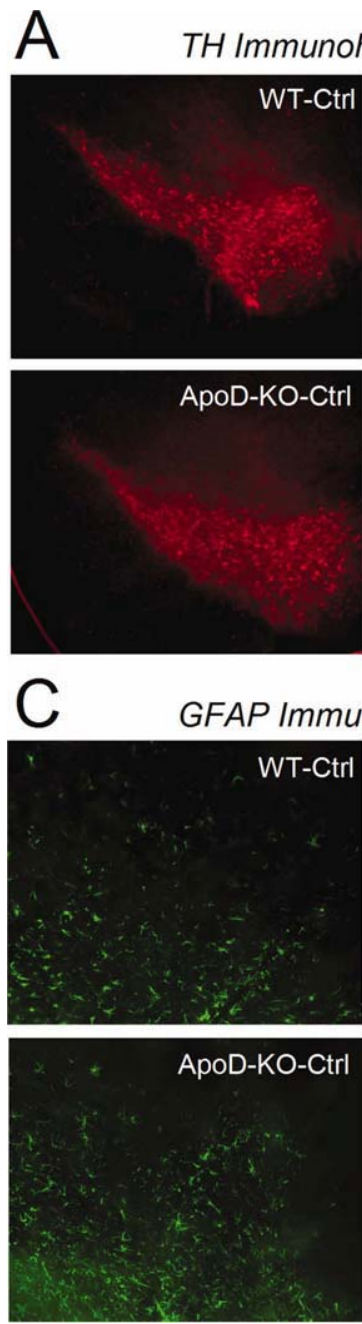
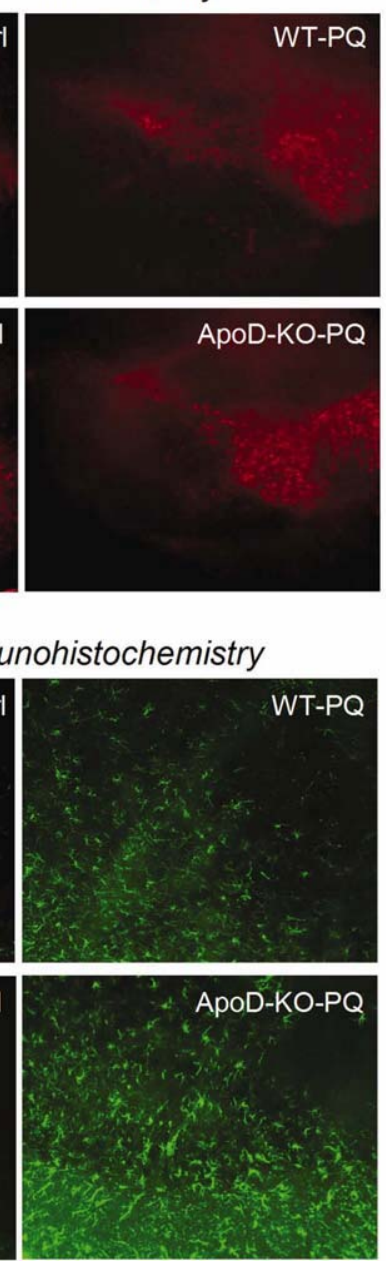

B

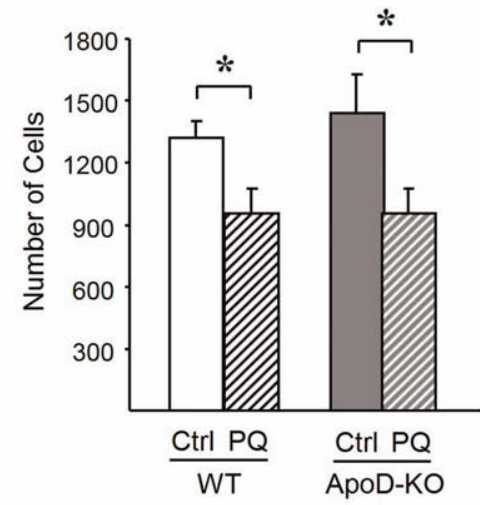

D

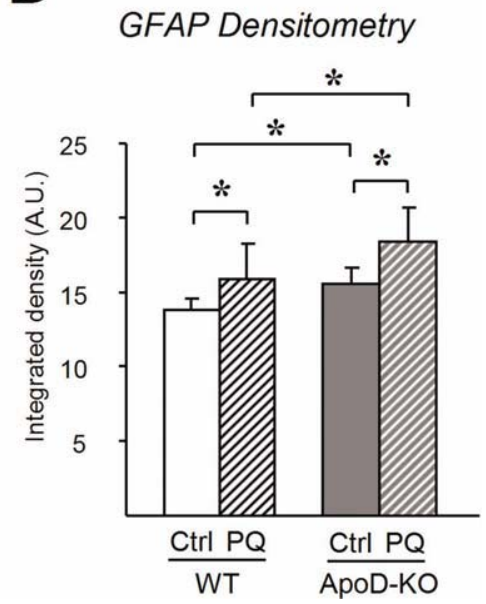

Fig. 2. ApoD influences astrocyte reactivity levels upon chronic PQ treatment without alterations in nigrostriatal neuronal cell death. A: Representative photomicrographs of TH immunohistochemistry in coronal mesencephalic slices performed seven days after the 7th PQ injection $\left(10 \mathrm{mg} \mathrm{kg}^{-1}\right)$. B: The number of TH-positive neurons in the SNc region decreases in a PQ-dependent manner in both ApoD-KO and WT mice. No genotype-dependent differences are detected. C: GFAP immu- nostaining in mesencephalic slices performed as in A. D: Quantification of GFAP immunoreactivity in the substantia nigra and interpeduncular regions reveals basal differences in the level of astroglial reactivity, and an enhanced response to chronic PQ treatment in the ApoD-KO mice. Data shown as mean $\pm \mathrm{SD}(\mathrm{B}, \mathrm{D}) . N=6$ mice/genotype. Unpaired Student's $t$-test; $* P<0.05$. [Color figure can be viewed in the online issue, which is available at wileyonlinelibrary.com.] ing SNc obtained seven days after the last PQ dose. We focused on genes that can be expressed by glial cells, since ApoD is not expressed by nigral dopaminergic neurons (Ordonez et al., 2006). Damage to neurons, and oxidative damage in general, triggers mainly astrocyte responses (Bajo-Grañeras et al., 2011; Rossi and Volterra, 2009) while inflammatory insults directly trigger microglial responses (Morale et al., 2006).

Since astroglial reactivity can be monitored by the expression of the cytoskeletal protein GFAP (Pekny and Nilsson, 2005; Sofroniew, 2009), we first evaluated the level of GFAP protein expression in ventral regions of the mesencephalon (Fig. S1). Our low-dose chronic PQ treatment causes an increase in basal astroglial reactivity and further increments over the already high basal level in ApoD-KO, as monitored by immunohistochemistry (Fig. 2B,C) and immunoblot of SN protein extracts (Fig. 3A).
These data suggest that $\mathrm{ApoD}$ is part of the mechanisms that restrain the extent of astrogliosis in vivo.

Heme oxygenase-1 (HO-1), a player in the early astroglial response and a sensitive and reliable reporter of tissue OS (Hsieh et al., 2010) still shows an increased up-regulation in ApoD-KO, both under control conditions and after being exposed to chronic PQ (Fig. 3B). In addition to its antioxidant direct functions, HO1 triggers the expression of other protecting genes such as superoxide dismutase $2(\operatorname{Sod} 2)$ and glial-derived neurotrophic factor (Gdnf) (Frankel et al., 2000; Hung et al., 2010). ApoD-KO mice display both a higher basal level and an enhanced response to chronic PQ treatment of these genes (Fig. 3C,D). It is especially noticeable the increase in Gdnf mRNA expression (Fig. 3D), considered as an endogenous protective mechanism particularly effective in the nigrostriatal system during 

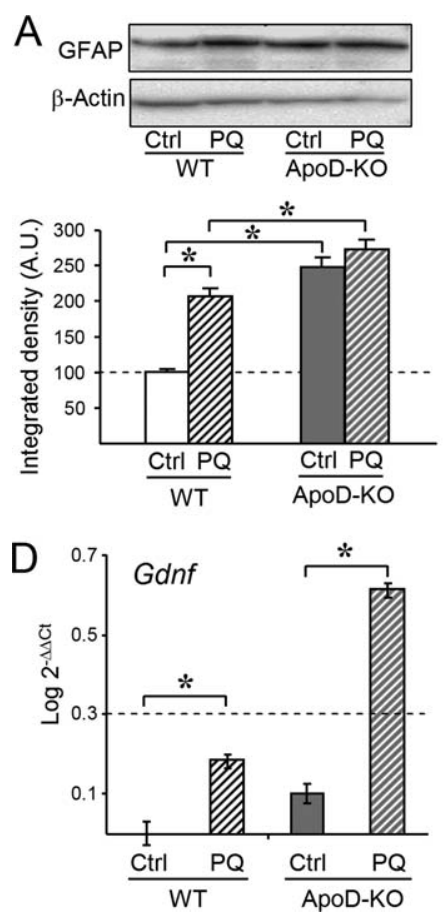
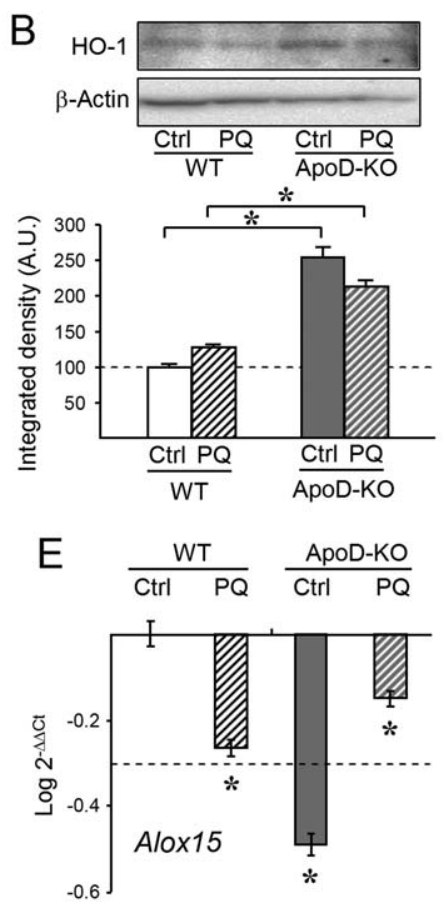
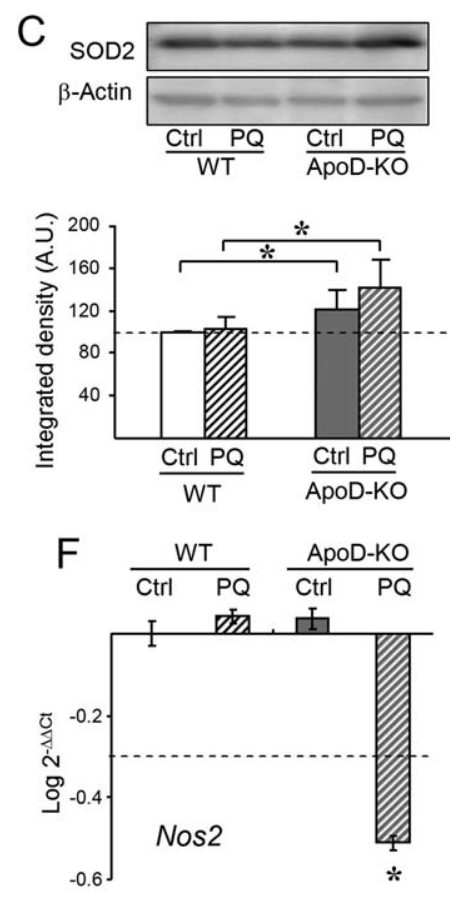

Fig. 3. Markers of astroglial reactivity and antioxidant response are altered in the substantia nigra of ApoD-KO mice. A-C: Immunoblot analysis of OS-dependent genes (GFAP, HO-1, and SOD2) shows elevated basal and PQ-triggered expression in the ApoD-KO substantia nigra. Graphs represent mean \pm SD of $2-4$ independent experiments (protein levels quantified by band densitometry normalized to $\beta$-actin signal). D-F: Quantitative RT-PCR analysis of Gdnf, Alox15,

Parkinson's disease (Morale et al., 2006; Villadiego et al., 2005). In contrast, 12/15 lipoxygenase (Alox15), an important mediator of neuronal cell death upon oxidative insult (Pallast et al., 2009), is down-regulated in the substantia nigra of ApoD-KO mice under control conditions, but its expression is up-regulated in response to $\mathrm{PQ}$ (Fig. 3E). The inducible NO synthase (Nos2), responsible for the production of NO and the subsequent generation of peroxynitrite, appears specifically down-regulated by chronic $\mathrm{PQ}$ in the ApoD-KO mice (Fig. 3F). Finally, the transcription of ApoE, an apolipoprotein with known antioxidant function (Poirier 2005), does not show genotype-dependent changes in the SN (not shown).

The molecular responses in the SN, together with the DA data described above, add to our previous findings (Ganfornina et al., 2008; Ganfornina et al., 2010) where the absence of ApoD provokes basal alterations in nervous system tissue homeostasis, generating an injury-like proinflammatory and pro-oxidant environment. Complex compensatory mechanisms are put forward, but they do not seem to include other nervous system apolipoproteins.

Since inflammation also plays a role in $\mathrm{PQ}$ toxicity (Mangano and Hayley, 2009), we measured the transcript levels of Il6 and Tnfa, cytokines of the early response to $\mathrm{PQ}$, and found no differential expression by genotype or chronic $\mathrm{PQ}$ treatment in the $\mathrm{SN}$ (not shown). Recently, we have found that acute high doses of $\mathrm{PQ}$ induce ApoD-dependent oligodendrocyte gene and Nos2 expression.. Protein and mRNA were extracted seven days after the 7 th $\mathrm{PQ}$ injection. $N=10$ mice/genotype. Dashed lines represent: the average protein level obtained in sham-injected WT animals (A-C), or a twofold change in mRNA concentration with respect to the calibrator sample (D, E). Statistical differences assayed by unpaired Student's $t$-test (A-C) and by Mann-Whitney U-test (D-F). $* P<0.05$.

expression responses in the cerebellum (Bajo-Grañeras et al., 2011). In contrast, no genotype-dependent differential expression of myelin genes was seen in the $\mathrm{SN}$ in response to chronic $\mathrm{PQ}$ (not shown), indicating that this experimental paradigm is able to trigger a specific astroglial response to oxidative damage, with minor contribution of microglial or oligodendrocyte responses. However, since many of the genes we have studied so far in the SN are also expressed by nigral neurons, oligodendrocytes or microglia under pro-oxidant conditions, we need to study astrocytes isolated in culture in order to discern how much of the ApoD-dependent response observed upon OS is of astroglial nature.

\section{ApoD Is Part of the Early Response of Astrocytes to Oxidative Stress}

To test if astrocytes are a source of ApoD in a brain exposed to $\mathrm{PQ}$ we first used the human astroglioma cell line 1321N1 (Ortmann and Perkins, 1977) and assayed ApoD expression at the mRNA (Fig. 4A) and protein (Fig. 4B,C) levels upon exposure to $\mathrm{PQ}$.

We first assayed how ApoD mRNA levels change with time, from the moment of plating until confluence is reached in the culture dish (48 $\mathrm{h}$ later) (Fig. S3A). As described for fibroblast-like and human astroglioma U373MG cell lines (Do Carmo et al., 2007), ApoD expression in $1321 \mathrm{~N} 1$ cells is low when they are 
A

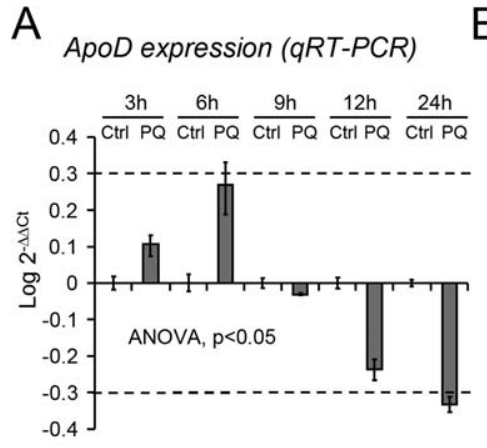

D

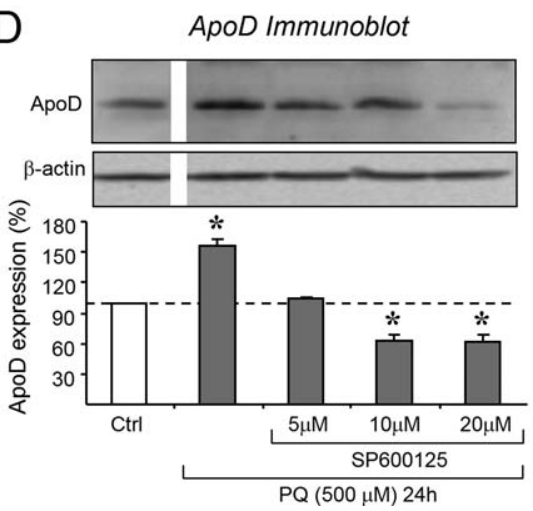

B

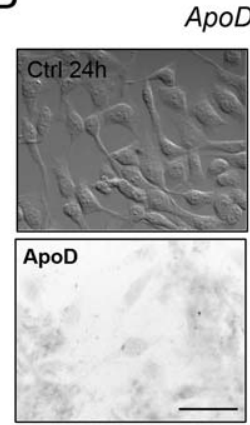

$\mathrm{E}$
ApoD Immunocytochemistry

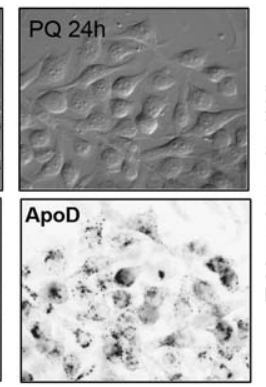

ApoD Immunoblot

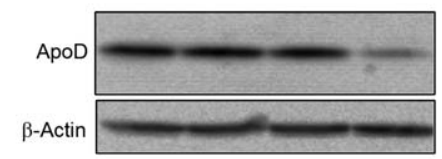

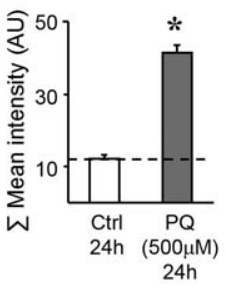

$\mathrm{F}$
C ApoD Immunoblot

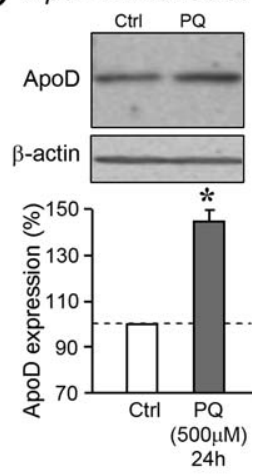

ApoD expression (qRT-PCR)

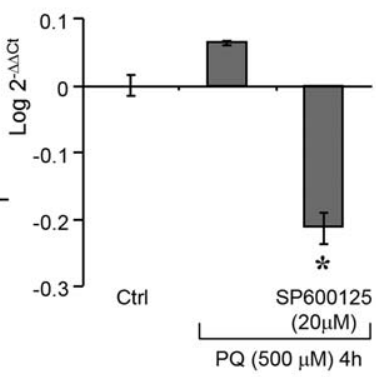

Fig. 4. Human ApoD is induced by PQ downstream of JNK in the astroglioma cell line $1321 \mathrm{~N} 1$. A: ApoD mRNA expression is transiently induced upon exposure to $500 \mu \mathrm{M}$ PQ. Relative amounts with respect to untreated cells in each time point is shown. B: High levels of ApoD protein expression are observed by densitometry analysis of the immunoreactivity signal after PQ treatment $(24 \mathrm{~h})$. Calibration bar: $50 \mu \mathrm{m}$. C: Quantification of ApoD by immunoblot analysis after PQ treatment (24 h). D: Activation of the JNK pathway is required for the PQ-dependent ApoD induction. ApoD is detected by immunoblot upon PQ exposure $(24 \mathrm{~h})$ plus increasing concentrations of the JNK inhibitor SP600125. E: Effect of JNK inhibitor on ApoD protein expression in control condi-

actively dividing, and is induced by growth arrest. PQ exposure was therefore performed in exponentially growing cells, to avoid the potential interaction of two different stimuli (growth arrest and OS), and for a maximum of $24 \mathrm{~h}$. We chose $500 \mu \mathrm{M}$ as the $\mathrm{PQ}$ dose reaching a maximum cell death (estimated from PI incorporation; not shown).

The time course of mRNA induction upon PQ exposure (Fig. 4A) indicates that ApoD is part of the early response of astrocytes to $\mathrm{OS}$, reaching a peak induction $6 \mathrm{~h}$ after exposure to $\mathrm{PQ}$. ApoD protein maintains its presence for longer periods (Fig. 4B,C and Fig. S3B). This is in agreement with the results obtained in vivo after chronic PQ treatment (Fig. S2). U373MG astroglioma cells show similar patterns of ApoD mRNA and protein expression (not shown). The decrease of ApoD transcript upon long exposures to $\mathrm{PQ}$ indicates the existence of a fine regulation of its expression, and that a continuous accumulation of ApoD protein might not be necessary or convenient for the cell after an oxidative insult. Interestingly, other acute-response genes in response to OS also show this finely timed regulation (Olesen et al., 2008; Wang et al., 2008). tions. F: JNK inhibitor prevents the induction of ApoD mRNA upon PQ exposure $(4 \mathrm{~h})$. Quantitative RT-PCR values are represented with respect to control conditions (calibrator sample). Densitometry values in $\mathrm{C}-\mathrm{E}$ are shown as percentage of control value after normalization to $\beta$-actin signal. Dashed lines represent: a twofold change in mRNA concentration with respect to calibrator sample (A), or the average protein level obtained in untreated cells (B-E). Graphs in C-E represent mean $\pm \mathrm{SD}$ of three to four independent experiments. Statistical differences assayed by ANOVA (A), unpaired Student's $t$-test (B-E) and MannWhitney $U$-test $(F)$. $* P<0.05$.

\section{The Stress Responsive JNK Signaling Pathway Regulates ApoD Transcription in Astrocytes}

The Jun-N-terminal Kinase (JNK) signaling pathway is activated by PQ in PC12 and SH-SY5Y neuronal cell lines and to mediate $\mathrm{PQ}$-induced dopaminergic cell apoptosis (Fei et al., 2008; Klintworth et al., 2007). Since Neural Lazarillo (NLaz), one of the ApoD homologous genes in Drosophila, is a downstream target of JNK in response to stress (Hull-Thompson et al., 2009), we hypothesized that the induction of ApoD transcript observed in astrocyte cell lines is triggered by JNK activation.

To test this idea we used the specific JNK inhibitor SP600125. As expected for targets of the JNK signaling cascade, both protein and mRNA levels of ApoD were reduced in the presence of the inhibitor in $1321 \mathrm{~N} 1$ cells treated with $\mathrm{PQ}$ (Fig. 4D,F). Furthermore, inhibition of JNK pathway activity in untreated control cultures reduces ApoD protein expression (Fig. 4E), indicating that JNK activity contributes to the basal level of ApoD expression. This effect also agrees with the observation that JNK inhibition in the presence of $\mathrm{PQ}$ leads to levels of mRNA below the control condition (Fig. 4F). 


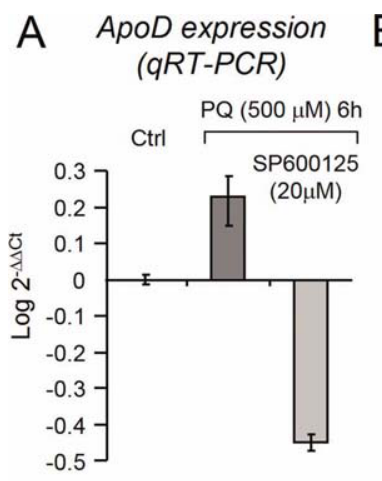

C

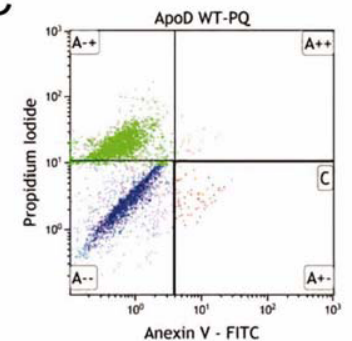

B
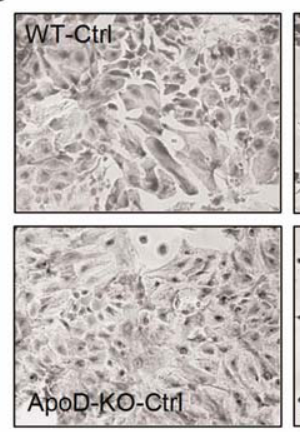

Apoptosis assay (Annexin $\mathrm{V}-\mathrm{PI})$
Viability assay (MTT)
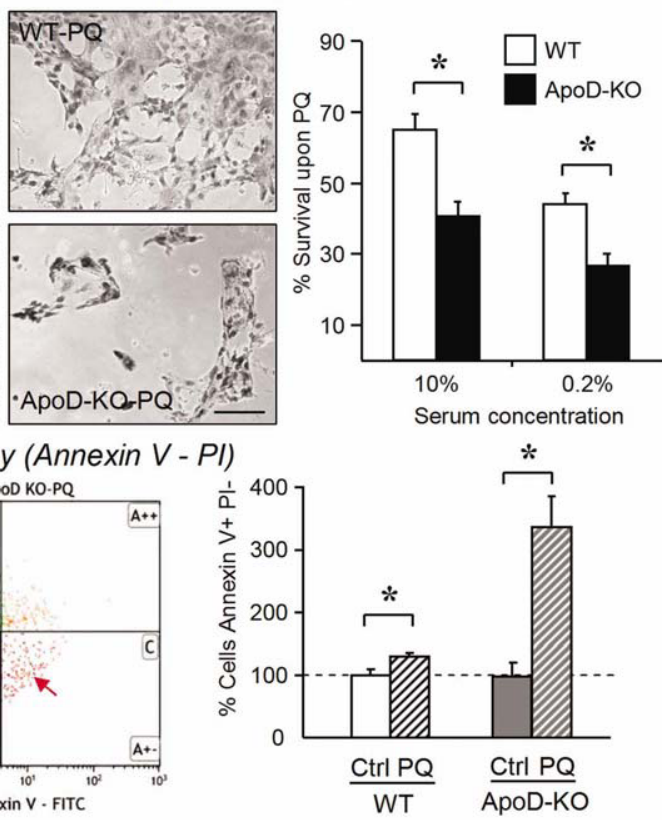

GFAP Immunofluorescence
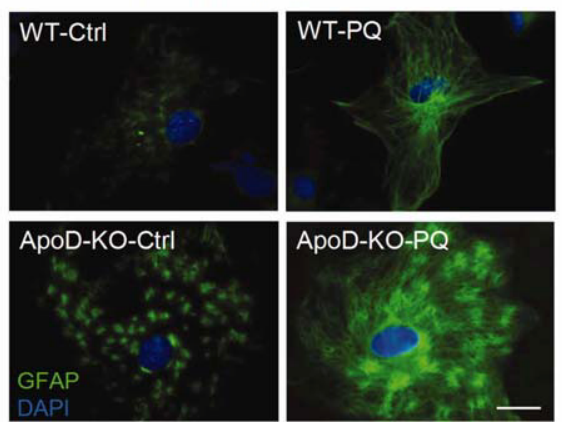

GFAP densitometry

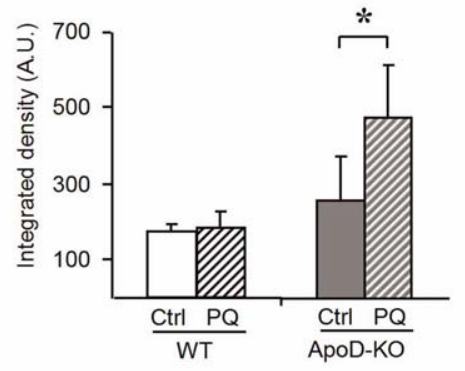

Fig. 5. Increased vulnerability and reactivity of ApoD-KO primary astrocytes. A: JNK pathway activity is required for the PQ-dependent ApoD induction in primary astroglial cultures. Mouse ApoD mRNA expression upon exposure to $500 \mu \mathrm{M} \mathrm{PQ}(6 \mathrm{~h})$ with or without JNK inhibitor SP600125 $(20 \mu \mathrm{M})$. B: Astrocyte viability measured by MTT assay upon $24 \mathrm{~h} \mathrm{PQ}$ treatment. Percent survival calculated in relation to untreated cells of each genotype. Pictures are representatives of a single experiment. Graph shows mean \pm SD of three to four independent experiments in each serum condition. C: Flow cytometry analysis of Annexin V-FITC and PI double-labeled cells. Most PQ induced cell death is non-apoptotic (upper-left quadrant), but a significantly higher proportion of cells enter apoptosis in ApoD-KO primary astrocytes cultures (arrow). Dot plots show a representative experiment. Graph shows mean $\pm \mathrm{SD}$ of three independent measures. D: Astroglial reactivity assayed by GFAP expression in primary cultures. In addition to the qualitative differences in GFAP distribution, ApoD-KO astrocytes show a higher induction of GFAP upon PQ treatment $(6 \mathrm{~h})$. Statistical differences assayed by Mann-Whitney $U$-test (A) or Student's $t$-test (C,D). ${ }^{*} P<$ 0.05 . Calibration bars: $50 \mu \mathrm{m}$ (B), $10 \mu \mathrm{m}$ (D). [Color figure can be viewed in the online issue, which is available at wileyonlinelibrary.com.]

\section{ApoD Deficient Astrocytes Become Vulnerable to Oxidative Stress}

To explore the functional significance of ApoD expression in astrocytes, we used primary astrocyte-enriched cortical glial cultures (referred to as astrocyte cultures henceforth) derived from postnatal brains (McCarthy and de Vellis, 1980) of WT and ApoD-KO mice.

Like human ApoD in astrocytoma cell lines, mouse ApoD in primary astrocytes is transcriptionally upregulated downstream of JNK signaling activity upon PQ exposure (Fig. 5A).

Since astrocytes are resistant to many forms of stress (Liddell et al., 2010) we tested whether ApoD is one of the factors contributing, through an autocrine mecha- nism, to their outstanding ability to survive. We assayed viability using the MTT assay. The lack of ApoD clearly renders primary astrocytes more vulnerable to PQ (Fig. $5 \mathrm{~B}$ ), and this effect is independent of the serum concentration used in the culture medium.

Astrocytes are known to undergo apoptosis when challenged with strong proinflammatory stimuli $(\mathrm{Hu}$ and Van Eldik, 1996; Takuma et al., 2004). However, apoptotic cell death was negligible in astrocytoma cell lines upon PQ treatment (measured by active caspase 3 detection or Annexin V labeling; not shown). Likewise, cell death induced by $\mathrm{PQ}$ in primary astrocytes was mainly non-apoptotic, as evidenced by Annexin V-PI in vivo labeling and flow cytometry (Fig 5C). However, a clear difference between ApoD-KO and WT astrocytes is that 


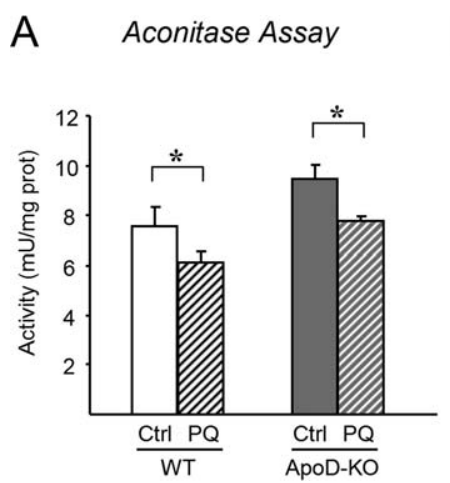

Fig. 6. Lipid peroxidation increases in ApoD-KO astrocytes without alterations in aconitase activity. A: Reduction of aconitase activity (Bioxytech Aconitase-340 assay) after PQ treatment $(2.5 \mathrm{~h}, 500 \mu \mathrm{M})$ is similar in ApoD-KO and WT astrocytes. B, C: Lipid peroxidation, assayed by TBARS (B) or by MDA-586 assay (C) is basally increased in ApoD-

a significant proportion of ApoD-KO astrocytes enter apoptosis, as revealed by Annexin V-positive PI-negative labeling (Fig. 5C, arrow). Similar results are obtained when apoptosis is assayed by TUNEL and quantified by fluorescence image densitometry (Fig. S4).

\section{ApoD Modulates Astrocyte Reactivity}

The increase in GFAP immunoreactivity in the SN of ApoD-KO mice (Fig. 2B,C and Fig. 3A), could be due to a higher number of reactive astrocytes in the tissue and/ or a higher reactive state of astrocytes. A significant increase in GFAP immunoreactivity is also observed after 6 hours of $\mathrm{PQ}$ treatment in ApoD-KO astrocytes (Fig. 5D, lower right panel; see also immunoblot in Fig. $9 \mathrm{E})$. This up-regulation of GFAP protein could be controlled at transcriptional levels, since the lack of ApoD up-regulates Nfla, a known activator of GFAP gene transcription, upon acute $\mathrm{PQ}$ treatment in the cerebellum (Bajo-Grañeras et al., 2011).

Following PQ treatment, WT astrocytes show a GFAP distribution in long cytoskeletal stress fibers commonly observed in reactive astrocytes (Pekny and Nilsson, 2005; Sofroniew, 2009). Many ApoD-KO astrocytes presented a spotted distribution of GFAP (Fig. 5D lower panels). Since the intermediary filament cytoskeleton is a sensitive sensor of toxic effects upon astrocytes (Pekny and Nilsson, 2005; Renau-Piqueras et al., 1989), this cellular distribution of GFAP might be the result of a basal stress produced by the lack of ApoD.

\section{ApoD Deficiency Increases Lipid Peroxides in Astrocytes Without Major Apparent Effects on Earlier Steps of the PQ-Triggered Oxidative Cascade}

Null mutants of ApoD or its homologous genes show an increased amount of peroxidated lipids in whole body fly extracts (Hull-Thompson et al., 2009; Sanchez et al.,
KO astrocytes. Exposure to PQ $(24 \mathrm{~h})$ further increases the accumulation of lipid peroxide adducts $(B)$. Data represent mean $\pm \mathrm{SD}$ of two to four independent experiments. Statistical differences assayed by unpaired Student's $t$-test, $* P<0.05$.

2006) or in mouse brain homogenates (Ganfornina et al., 2008). Since lipid peroxidation in cellular membranes is a major sink for reactive oxygen species (ROS), a greater amount of peroxidated lipids can be due to a higher rate of production or to a slower rate of removal/recycling of the damaged membranes. High peroxidation rates would be accompanied by elevated ROS levels in the cell. We assayed aconitase activity as a very sensitive and early sensor of ROS levels in the cell, since its activity is quickly lost by oxidation-mediated loss of Fe from its $\mathrm{Fe}$ S prosthetic group (Yan et al., 1997).

We find no decrease in aconitase activity in ApoD-KO astrocytes, and the activity reduction after a 2.5 -h exposure to $\mathrm{PQ}$ was comparable in both genotypes (Fig. 6A). Therefore, the absence of ApoD does not directly increase the production or net level of ROS, since this would be evidenced by a stronger aconitase inactivation. However, ApoD-KO astrocytes show elevated basal levels of peroxidated lipids and proportionally higher levels of these ROS by-products in response to $\mathrm{PQ}$ exposure (Fig 6B,C).

These data strongly suggest that ApoD prevents the accumulation of peroxidated lipids in astrocytes, possibly by promoting their removal from damaged membranes.

\section{Astrocytes Transcriptional Response to Oxidative Stress Is Modified by ApoD}

The results above indicate that, in the absence of ApoD, astrocytes are still able to control the early steps in ROS management while accumulating lipid peroxides. To understand the global response of astrocytes to OS and the contribution of ApoD, we surveyed the transcription of 84 OS responding genes.

Thirty-four genes do not show significant treatment or genotype-dependent changes. They are either genes not expressed by glial cultures, many of them in agreement with previous transcriptional profile analyses in astrocytes (Nakagawa and Schwartz, 2004; Olesen et al., 2008), or genes that do not respond to the particular OS conditions we explore (500 $\mu \mathrm{M}$ PQ for $24 \mathrm{~h})$. 


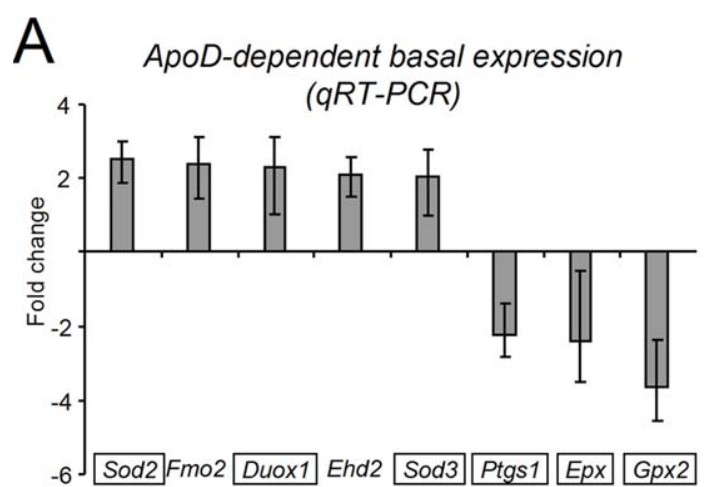

Fig. 7. Quantitative RT-PCR expression profiles of primary astrocyte cultures. A: Subset of genes with statistically significant changes in basal expression levels in ApoD-KO astrocytes. Expression level in WT untreated astrocytes is used as calibrator for each gene. B: Cluster analysis and heat map of the 18 genes that showed genotype-dependent significant differences in their response to PQ (24-h treatment). Col-

A set of 37 genes showed significant $\mathrm{PQ}$-dependent changes in WT cells, with $31 \%$ of them being upregulated (Table S1). This transcriptional profile reveals an interesting response of astrocytes to OS, as genes with pro-oxidant functions are down-regulated by $\mathrm{PQ}$ as part of an adaptive response to the oxidative insult. Moreover, many of the acute-response genes appear down-regulated at $24 \mathrm{~h}$ after their peak induction.

Only eight genes show genotype-dependent changes in control conditions (Fig. 7A). Five genes are up-regulated in ApoD-KO astrocytes, and in most of them (75\%) the changes mimic the response of WT cells under PQ treatment.

ApoD-KO astrocytes respond to $\mathrm{PQ}$ with transcriptional changes in 46 genes. Eighteen genes (Table 1) display significantly different responses to $\mathrm{PQ}$ (more than two-fold difference in expression) between genotypes. A heat map representation is shown in Fig. 7B, and Fig. S6 displays a visual representation integrated with the functional networks formed among them. This pattern suggests that the absence of ApoD dampens the response to $\mathrm{PQ}$ of astrocytes, which are otherwise basally stressed (note that six out of the 18 genes also show genotype-dependent changes in basal conditions; boxed in Fig. 7).

The low number of genotype-affected genes indicates that changes in the response to $\mathrm{PQ}$ are not an indirect consequence of a pro-oxidant environment caused by the lack of ApoD, since that would trigger a generalized antioxidant defense response. Among the genes with a decreased response to $P Q$ in the absence of ApoD are crucial ROS managing enzymes (Sod2, Sod3, Gpx3, Duox1, and Srxn1) and key proteins involved in inflammation signaling (Ptgs2-COX2, Ptgs1-COX1, Il19).

In summary, the specific transcriptional changes observed can explain a higher vulnerability of ApoD-KO astrocytes to OS, and support that ApoD exerts autocrine protective functions.

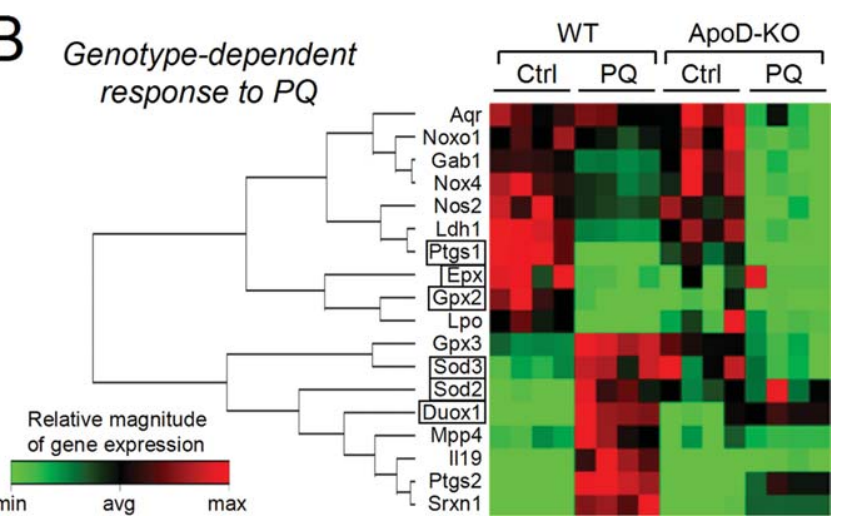

umns represent samples. Rows represent genes. Color-coded relative quantification scaling is shown at the bottom. Fold change values for each gene are listed in Table 1. Genes common to subset A and B are boxed. Only statistically supported changes (Mann-Whitney's $U$-test, $P<0.05$ ) with a fold change $\geq 2$ are shown.

TABLE 1. Subset of Genes with Genotype-Dependent Expression in Response to $P Q$ Treatment

\begin{tabular}{lcr}
\hline & WT & ApoD-KO \\
& Fold change & Fold change \\
\hline II19 & $462.08 \pm 83.6$ & $21.09 \pm 6.3$ \\
Ptgs2 & $70.88 \pm 6.6$ & $18.25 \pm 4.7$ \\
Duox1 & $11.06 \pm 1.3$ & $3.55 \pm 0.3$ \\
Srxn1 & $8.22 \pm 1.1$ & $4.34 \pm 0.1$ \\
Sod2 & $3.62 \pm 0.8$ & $1.11 \pm 0.3$ \\
Gpx3 & $2.34 \pm 0.2$ & $-2.31 \pm 0.6$ \\
Sod3 & $2.32 \pm 0.5$ & $-2.26 \pm 0.6$ \\
Mpp4 & $2.31 \pm 0.4$ & $1.07 \pm 0.1$ \\
Aqr & $-1.05 \pm 0.1$ & $-2.67 \pm 0.9$ \\
Noxo1 & $-1.39 \pm 0.2$ & $-4.21 \pm 1.2$ \\
Nos2 & $-1.76 \pm 0.1$ & $-3.43 \pm 0.9$ \\
Nox4 & $-1.87 \pm 0.2$ & $-3.91 \pm 0.8$ \\
Gab1 & $-1.99 \pm 0.1$ & $-5.56 \pm 2.0$ \\
Idh1 & $-2.83 \pm 0.1$ & $-4.41 \pm 1.2$ \\
Epx & $-2.88 \pm 0.3$ & $1.07 \pm 0.5$ \\
Gpx2 & $-5.08 \pm 1.2$ & $-1.32 \pm 0.1$ \\
Lpo & $-5.78 \pm 0.9$ & $-2.01 \pm 0.5$ \\
Ptgs1 & $-70.85 \pm 13.1$ & $-39.43 \pm 13.7$ \\
\hline
\end{tabular}

Fold change (FC) with respect to untreated cultures of each genotype is listed (mean $\pm \mathrm{SD}$ of four replicas). Criteria for gene selection were: (i) Statistically supported changes with $\mathrm{PQ}$ (Mann-Whitney's $U$-test, $P<0.05$ ), and (ii) $\mathrm{FC}(\mathrm{KO})= \pm 2$ FC(WT).

\section{Exogenous Addition of ApoD Improves ApoD-KO Astrocytes Viability Upon PQ Exposure}

Because the astrocyte response to $\mathrm{PQ}$ includes a JNKmediated induction of ApoD (Fig. 5A), and without ApoD they become more vulnerable to OS (Fig. 5B), we hypothesized that addition of ApoD to ApoD-KO astrocytes would be beneficial. We simultaneously treated primary astrocytes with $\mathrm{PQ}$ and human ApoD (hApoD, purified from breast cyst fluid) at different concentrations (Fig. 8). Viability, measured by MTT assay, clearly improves when $\mathrm{hApoD}$ is added to ApoD-KO astrocytes (Fig. 8A).

The effect reaches a plateau at $4-8 \mathrm{nM}$, with additional increases of hApoD (up to $20 \mathrm{nM}$ ) resulting in no further viability improvement (not shown). Curiously, adding hApoD to WT astrocytes did not improve viability (Fig. 8B), and no significant changes were observed at high concentrations (up to $20 \mathrm{nM}$, not shown). 


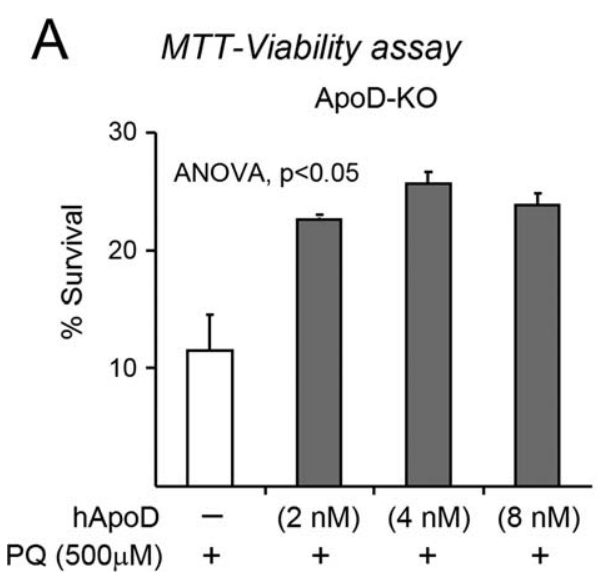

Fig. 8. Exogenous addition of human ApoD (hApoD) promotes survival of astrocytes upon $\mathrm{PQ}$ exposure in the absence of endogenous ApoD. A: Addition of increasing concentrations of hApoD to mouse astrocyte cultures at the time of $\mathrm{PQ}$ treatment improves survival up to 2.2-fold in ApoD-KO astrocytes. B: Survival of WT astrocytes is

These results show that the ApoD available in the extracellular environment is recruited to the defense response organized by astrocytes against OS.

\section{Exogenous ApoD Is Internalized by Astrocytes in a Genotype-Dependent Manner}

Exogenously administered ApoD has been described to be internalized by various cell lines and located in different subcellular compartments, including the nucleus and the cytoplasm (Do Carmo et al., 2007; Liu et al., 2001; Sarjeant et al., 2003; Thomas et al., 2003). The protective effect of $\mathrm{hApoD}$ reported in $\mathrm{PQ}$-challenged astrocytes led us to test the internalization of hApoD by primary murine astrocytes, and whether there are differences between ApoD-KO and WT astrocytes.

Human ApoD was detected inside the cells when added to primary astrocytes, both by immunocytochemistry (Fig. 9A-C) and immunoblot of cell protein extracts after extensive replacement of media supernatant (Fig. 9D,E). The antibody used in these experiments fails to recognize the endogenous mouse ApoD in WT astrocytes (immunocytochemistry, not shown; Lanes 1 and 3 in Fig. 9D,E). Internalization of hApoD was observed in ApoD-KO and WT astrocytes (Fig. 9B) with a lighter labeling in WT cells. Quantification of hApoD inmunoblot signals (Fig. 9D,E; red bars) confirmed the latter observation. Thus, ApoD-deficient mouse astrocytes do incorporate more hApoD than WT astrocytes. Remarkably, this difference in internalization is observed in control conditions, but not upon PQ treatment, where cells show a lower content of hApoD (Fig. 9D,E) after 24-h treatment with PQ. This effect might be due to less incorporation or a faster transit of the exogenous protein through the cell.

The analysis of confocal images (Fig. 9C) show hApoD signal in a pattern resembling the intracellular membranous and vesicular compartments, particularly in the perinuclear area, but was not observed inside the nu-

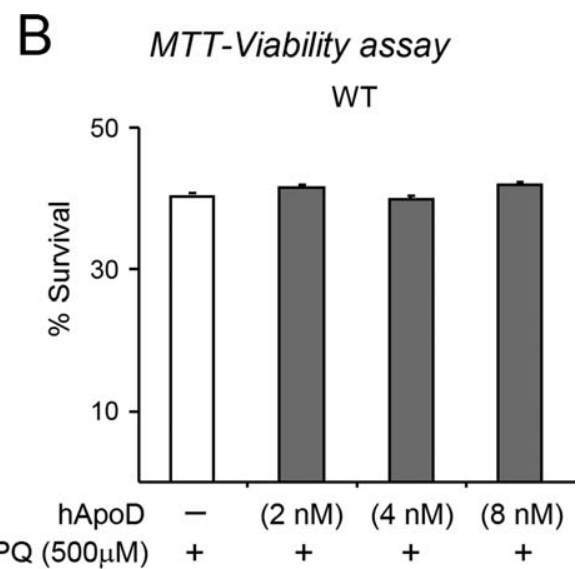

however unaltered by hApoD treatment. Percent survival upon 24-h PQ treatment (MTT assay) relative to the untreated cells of each genotype is shown. Data presented as mean $\pm \mathrm{SD}$ of three to five independent experiments. Statistical differences assayed by ANOVA test, $* P<0.05$

cleus, either in control conditions (Fig. 9C) or under PQ treatment (not shown).

To test whether this internalization might be a general and unspecific phenomenon, we performed the same experiment in two different cell types, HEK and HeLa cells that have negligible endogenous $\mathrm{hApoD}$ expression. When hApoD is added in the same range of concentrations used in the primary astrocyte experiments, HeLa, but not HEK cells, clearly internalize hApoD (Fig. S5). These experiments suggest that internalization is not due to unspecific endocytosis of proteins from the culture medium, and are compatible with a specific receptor-mediated endocytosis.

Changes in endocytosis and in the amount of intermediary cytoskeletal filaments have been shown to coexist in astrocytes exposed to pro-oxidant stimuli such as unconjugated bilirubin (Silva et al., 2001). Since ApoD influences astrocyte reactivity (Fig. 5D), we tested whether this effect was correlated with the amount of hApoD detected in cell extracts. We found that hApoD immunoreactivity was negatively correlated with GFAP (Fig. 9D,E, green bars). Therefore, the lack of ApoD is associated with more GFAP, particularly under PQ treatment both in vitro and in vivo (Fig. 9E; see also Fig. 2C,D and Fig. 5D), and the exogenous addition of hApoD is able to partially counteract this effect. Our data suggest that ApoD has an inhibitory effect on astrocyte reactivity that might be functionally linked to a finely regulated autocrine safety mechanism and, ultimately, to the protection of highly vulnerable dopaminergic neurons.

\section{DISCUSSION}

ApoD is linked to aging, degeneration and injury of the nervous system. Recent work from model organisms as divergent as plants, flies, and mice (Charron et al., 2008; Ganfornina et al., 2008; Hull-Thompson et al., 2009; Ruiz et al., 2011; Sanchez et al., 2006) has demonstrated 

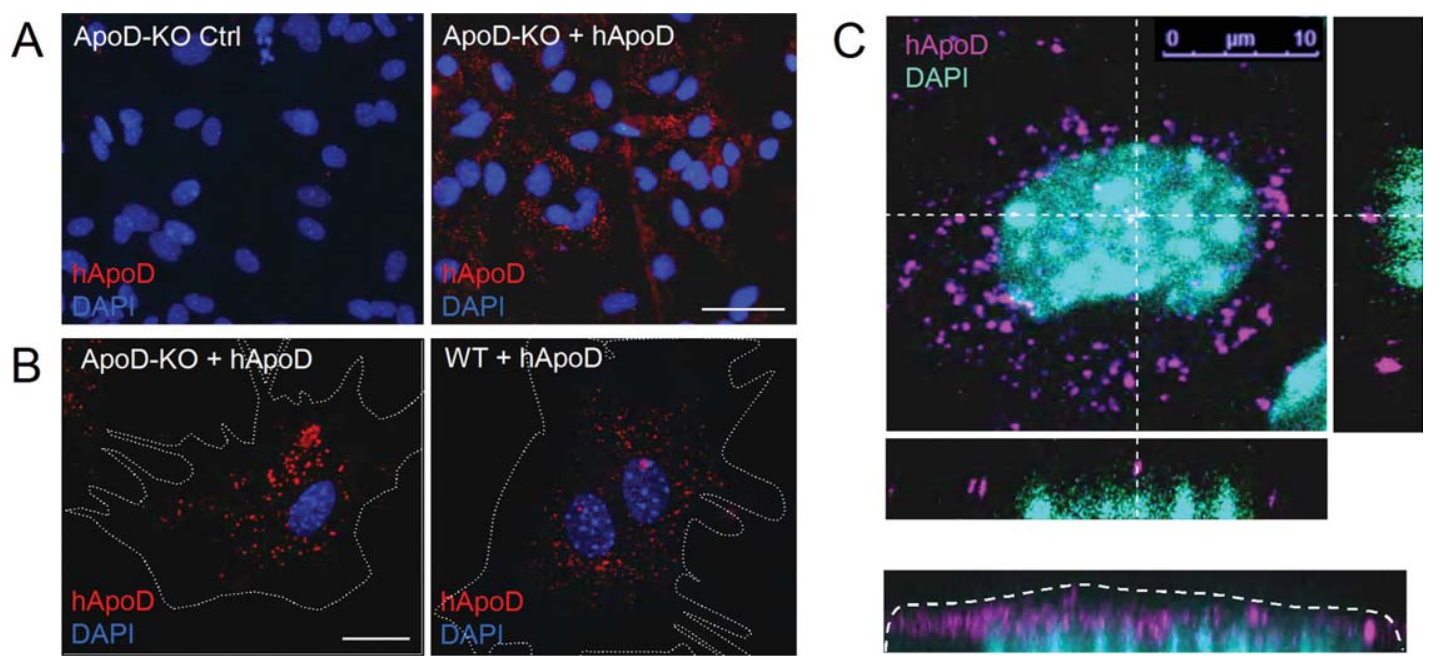

D Immunoblot (WT culture)

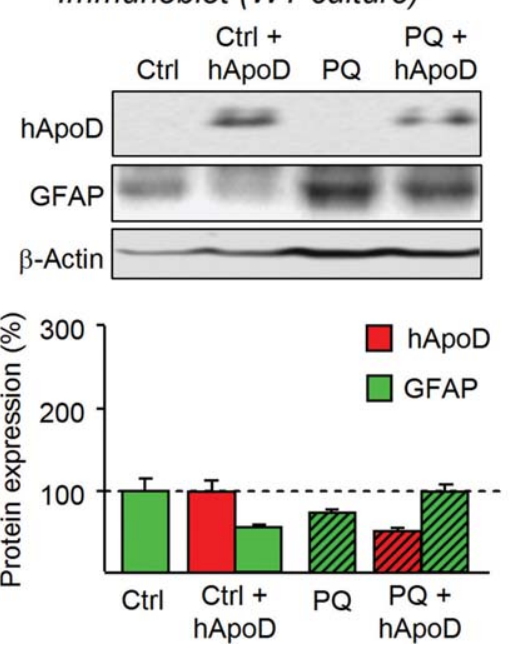

Fig. 9. Exogenous ApoD effects on survival are accompanied by internalization of the protein and modulation of astroglial reactivity. A-C: Immunofluorescence analyses of hApoD incorporation. Nuclei are labeled with DAPI. A: Fluorescence microscopy images of primary mouse astrocytes in control conditions in the absence (left panel) or presence of $4 \mathrm{nM}$ hApoD. B: Confocal microscopy images show that $\mathrm{hApoD}$ is internalized by both ApoD-KO and WT astrocytes. Contours of cells were delineated after DIC optic images (not shown). C: Maximal projection of a $z$-series. Orthogonal $z$-projections of the axes

that ApoD contributes to conserved survival mechanisms against OS. The link we previously found between lipid peroxides management in the brain and ApoD expression (Ganfornina et al., 2008) suggests that ApoD performs a protective function through the control of OS byproducts. However, no direct proof was available for establishing a causal relationship between $\mathrm{ApoD}$ and the vulnerability of a functional nervous system to OS.

In this work we demonstrate that: (i) ApoD contributes to the protection of the OS-sensitive dopaminergic system; (ii) ApoD expression is triggered in astrocytes downstream of the stress-sensitive JNK pathway; (iii) ApoD contributes to restrain astrogliosis; and (iv) ApoD secreted by astrocytes provides autocrine protection for these resilient glial cells against PQ-induced OS.

\section{ApoD Function in the Physiology of the Nigrostriatal Dopaminergic System}

Our results show that ApoD deficiency enhances the damaging effects of $\mathrm{PQ}$ in the mouse dopaminergic system. We chose a PQ treatment that avoids systemic toxicity and maximizes the OS effects on sensitive brain regions (Prasad et al., 2009). The evident bradikynesia of ApoD-KO mice, even under a mild $\mathrm{PQ}$ paradigm, reflects an indispensable role of $\mathrm{ApoD}$ for establishing a proper antioxidant defense in the brain. Functional alterations of dopaminergic systems are also supported by the significant differences in DA content found in the PQ-challenged brain of ApoD-KO mice, despite diluting the striatal enrichment in PQ-sensitive dopaminergic terminals by including regions that are 
more resistant to $\mathrm{PQ}$-induced $\mathrm{OS}$ (Wang et al., 2009). The basal increase in DA in the anterior brain of ApoD-KO mice is a puzzling observation that awaits further study. It might be due to compensatory increases in different dopaminergic regions. Interestingly, Chadchankar et al. (2011) show increased extracellular DA levels in the striatum of alphasynuclein deficient mice, indicating that compensatory mechanisms within the nigrostriatal system are taking place in different experimental approximations to PD. Moreover, the number of TH-positive neurons shows a trend to increase in the ApoD-KO SNc in control condition (Fig. 2B), which might explain, if confirmed with larger samples, the slight increase in forebrain DA levels.

Our study of the SN molecular response to $\mathrm{PQ}$ revealed both constitutive and OS-induced differences between ApoD-KO and WT animals. The expression changes comprise basally elevated levels of the glial reactivity sensor GFAP, also observed in situ in mesencephalic slices, and the antioxidant proteins HO-1 and Sod2, all of which stay elevated after a chronic PQ treatment. We also found specific PQ-dependent up-regulations for the OS-protecting factor Gdnf and the OS amplifier Alox15. Altogether these gene expression differences suggest the existence of a sustained OS in the neuronal environment of ApoD-KO mice, and an anomalous response of the gene network that needs to be organized to cope with the PQ-induced OS.

\section{ApoD Role in the Astroglial Response to Oxidative Stress}

The lack of ApoD makes astrocytes more vulnerable to PQ treatment, and the exogenous addition of hApoD improves the viability of ApoD-deficient astrocytes. Since ApoD is expressed by astrocytes, we can conclude that it mediates an autocrine protection that in turn contributes to the nervous system homeostatic response to OS.

Loss-of-function mutants of ApoD or its homologues consistently show an increase in their basal levels of lipid peroxidation (Ganfornina et al., 2008; Hull-Thompson et al., 2009; Sanchez et al., 2006). Here we demonstrate that astrocytes accumulate more lipid peroxides if deprived of ApoD. A parsimonious hypothesis would predict that ApoD is a general antioxidant; OS would occur in its absence, and damage to lipids, proteins and DNA would appear as a consequence. Direct antioxidant properties have been reported in vitro for a recombinant form of ApoD, able to scavenge hydroxyl radicals and prevent DNA oxidation (Zhang et al., 2010). However, our data support that, in vivo, ApoD acts on specific components of the antioxidant defense tools of astrocytes. Its absence does not produce a generalized response. Elements of the antioxidant cascade like catalase, peroxiredoxins, thioredoxin reductases, and most glutathione peroxidases do not have genotype-dependent changes of expression. With two superoxide dismutase genes (Sod2 and Sod3) up-regulated in ApoD-KO astrocytes in control conditions, superoxide radicals produced by metabolic activity are expected to be efficiently con- verted to $\mathrm{H}_{2} \mathrm{O}_{2}$. Detoxification of $\mathrm{H}_{2} \mathrm{O}_{2}$ by $\mathrm{Gpx}$ and Cat can be eventually overloaded, and dangerous levels of the highly reactive hydroxyl radical would slowly accumulate. This is compatible with the observation that aconitase activity (particularly sensitive to superoxide anions) is equally reduced in WT and ApoD-KO astrocytes, whereas lipid peroxides increase in the absence of ApoD. The net result is that some defense mechanisms are attenuated and some pro-oxidant mechanisms are exacerbated in ApoD-KO astrocytes, leading to a higher vulnerability of these cells to oxidation.

Particularly interesting are the changes observed in genes related to the inflammatory response to PQ (Il19 or Ptgs2 as examples of genes up-regulated by $\mathrm{PQ}$, and Ptgs1 among the genes down-regulated by $P Q$ ), that show a diminished response to $\mathrm{PQ}$ in the absence of ApoD. ApoD function could thus contribute to turn on a proper inflammatory glial reaction during the initial phase of the response against an OS situation.

The transcriptional regulation of ApoD by the JNK pathway, particularly involved in PQ-induced OS (Klintworth et al., 2007; Peng et al., 2004), also supports the specificity of the protective role of ApoD. The temporally biphasic regulation of ApoD mRNA (early up-regulation followed by down-regulation), the small accumulation of protein observed in the striatum after chronic PQ treatment, and the plateau in viability rescue obtained after exogenous addition of ApoD to PQ-challenged cultures, suggest that astrocytes have mechanisms to control an upper limit of ApoD expression and function.

The viability rescue in ApoD-KO astrocytes is partial, indicating that ApoD is one of several genes involved in the response to OS. The effect of hApoD supplementation reaches saturation, suggesting the existence of a receptor-mediated process. However, no clear demonstration has been documented of a specific cell membrane receptor for ApoD. The fact that $h A p o D$ has no effect on the viability of $\mathrm{PQ}$-challenged WT astrocytes suggests that cells negatively regulate the availability of putative ApoD receptors. Thus, astrocytes expressing endogenous ApoD would not be receptive to further ApoD additions. This idea is in agreement with the tight transcriptional regulation described above.

Another consequence of our results is that ApoD clearly modulates astrocyte reactivity, both in primary glial cultures and in vivo, contributing to its inhibition or restrain. Interestingly, another Lipocalin known to be induced upon stress in the vertebrate nervous system, Lcn2, mediates astrocyte reactivity. Over-expressing or adding Lcn2 to astrocytes sensitizes them to cytotoxic stimuli and induces astrogliosis (Lee et al., 2009), while decreasing Lcn2 correlates with decreased astrogliosis (Zheng et al., 2009). Turning on and off glial reactivity can be therefore accomplished by the complementary actions of the two Lipocalins. In this scenario, our data suggest that ApoD could be an off signal for astroglial reactivity.

Conversely, ApoE is expressed by glia and known to down-regulate CNS pro-inflammatory genes (Lynch et al., 2001). ApoD and ApoE have been proposed to perform redundant functions because of their lipid-binding 
properties (Terrisse et al., 1999). However, ApoE expression levels are similar in the PQ-challenged WT and ApoD-KO primary cultures (not shown), as well as in the mesencephalon of mice exposed to chronic PQ treatment (see above). Also, the induction of ApoE by peripheral nerve injury is decreased in ApoD-KO nerves (Ganfornina et al., 2010), further supporting the hypothesis that these two lipoproteins play different and not compensatory functions. Lastly, and contrary to ApoD, ApoE has been recently shown to be induced by inhibiting the JNK pathway (Pocivavsek and Rebeck, 2009).

We propose a role for ApoD in maintaining the glial response to OS and the concomitant inflammatory reaction under fixed limits. Our results suggest that ApoD, ApoE, and Lcn2 form a complementary team controlling the on-off signals that tune the glial response to injury. Assessing the role of $\mathrm{ApoD}$ as on-off signal in the neuronal environment is next in our research program, by studying the position and contribution of ApoD in the functional network established among astrocytes, microglia and the OS vulnerable neurons.

\section{ACKNOWLEDGMENTS}

The authors thank J.R. Acebes for technical assistance, and the Lazarillo Lab (M. Ruiz, N. García-Mateo, M. del Caño, and A. Pérez-Castellanos) for their helpful discussions and positive criticisms. They thank C. Sánchez-Vicente at the Confocal Microscopy Service in IBGM for technical assistance. Cell lines 1321N1, U373, HEK, and HeLa were kindly provided by M. L. Nieto (IBGM-CSIC, Valladolid, Spain) and F. Aguado (Univ. Barcelona, Spain). Purified hApoD was a gift from E. Rassart (Univ. Quebec á Montreal, Canada).

\section{REFERENCES}

Bajo-Grañeras R, Sanchez D, Gutierrez G, Gonzalez C, Carmo SD, Rassart E, Ganfornina MD. 2011. Apolipoprotein D alters the early transcriptional response to oxidative stress in the adult cerebellum. J Neurochem 117:949-960.

Chadchankar H, Ihalainen J, Tanila H, Yavich L. 2011. Decreased reuptake of dopamine in the dorsal striatum in the absence of alphasynuclein. Brain Res 1382:37-44.

Charron JB, Ouellet F, Houde M, Sarhan F. 2008. The plant Apolipoprotein D ortholog protects Arabidopsis against oxidative stress. BMC Plant Biol 8:86.

de Magalhaes JP, Curado J, Church GM. 2009. Meta-analysis of agerelated gene expression profiles identifies common signatures of aging. Bioinformatics 25:875-881.

Do Carmo S, Levros L-C Jr, Rassart E. 2007. Modulation of apolipoprotein $\mathrm{D}$ expression and translocation under specific stress conditions. Biochimica et Biophysica Acta (BBA) - Mol Cell Res 1773:954-969.

Fei Q, McCormack AL, Di Monte DA, Ethell DW. 2008. Paraquat neurotoxicity is mediated by a Bak-dependent mechanism. J Biol Chem 283:3357-3364.

Frankel D, Mehindate K, Schipper HM. 2000. Role of heme oxygenase1 in the regulation of manganese superoxide dismutase gene expression in oxidatively-challenged astroglia. J Cell Physiol 185:80-86.

Ganfornina MD, Do Carmo S, Lora JM, Torres-Schumann S, Vogel M, Allhorn M, González C, Bastiani MJ, Rassart E, Sanchez D. 2008. Apolipoprotein D is involved in the mechanisms regulating protection from oxidative stress. Aging Cell 7:506-515.

Ganfornina MD, Do Carmo S, Martínez E, Tolivia J, Navarro A, Rassart E, Sanchez D. 2010. ApoD, a glia-derived apolipoprotein, is required for peripheral nerve functional integrity and a timely response to injury. Glia 58:1320-1334.

Hsieh H-L, Wang H-H, Wu C-Y, Yang C-M. 2010. Reactive oxygen species-dependent c-fos/activator protein 1 induction upregulates heme oxygenase-1 expression by bradykinin in brain astrocytes. Antioxidants Redox Signaling 13:1829-1844.

Hu J, Van Eldik LJ. 1996. S100 beta induces apoptotic cell death in cultured astrocytes via a nitric oxide-dependent pathway. Biochimica Biophysica Acta 1313:239-245.

Hull-Thompson J, Muffat J, Sanchez D, Walker DW, Benzer S, Ganfornina MD, Jasper H. 2009. Control of metabolic homeostasis by stress signaling is mediated by the lipocalin NLaz. PLoS Genet 5:e1000460.

Hung S-Y, Liou H-C, Fu W-M. 2010. The mechanism of heme oxygenase-1 action involved in the enhancement of neurotrophic factor expression. Neuropharmacology 58:321-329.

Klintworth H, Newhouse K, Li T, Choi W-S, Faigle R, Xia Z. 2007. Activation of c-Jun $\mathrm{N}$-terminal protein kinase is a common mechanism underlying paraquat- and rotenone-induced dopaminergic cell apoptosis. Toxicol Sci 97:149-162.

Lee S, Park J-Y, Lee W-H, Kim H, Park H-C, Mori K, Suk K. 2009. Lipocalin-2 is an autocrine mediator of reactive astrocytosis. J Neurosci 29:234-249.

Liddell JR, Robinson SR, Dringen R, Bishop GM. 2010. Astrocytes retain their antioxidant capacity into advanced old age. Glia 58:1500-1509.

Liu Z, Chang G-Q, Leibowitz SF. 2001. Apolipoprotein D interacts with the long form leptin receptor: A hypothalamic function in the control of energy homeostasis. Faseb J 15:1329-1331.

Loerch PM, Lu T, Dakin KA, Vann JM, Isaacs A, Geula C, Wang J, Pan Y, Gabuzda DH, Li C, et al. 2008. Evolution of the aging brain transcriptome and synaptic regulation. PLoS ONE 3:e3329.

Lynch JR, Morgan D, Mance J, Matthew WD, Laskowitz DT. 2001. Apolipoprotein E modulates glial activation and the endogenous central nervous system inflammatory response. J Neuroimmunol 114(12):107-113.

Mangano EN, Hayley S. 2009. Inflammatory priming of the substantia nigra influences the impact of later paraquat exposure: Neuroimmune sensitization of neurodegeneration. Neurobiol Aging 30:13611378 .

McCarthy KD, de Vellis J. 1980. Preparation of separate astroglial and oligodendroglial cell cultures from rat cerebral tissue. J Cell Biol 85:890-902.

McCormack AL, Thiruchelvam M, Manning-Bog AB, Thiffault C, Langston JW, Cory-Slechta DA, Di Monte DA. 2002. Environmental risk factors and Parkinson's disease: Selective degeneration of nigral dopaminergic neurons caused by the herbicide paraquat. Neurobiol Dis 10:119-127.

Miller RL, James-Kracke M, Sun GY, Sun AY. 2009. Oxidative and inflammatory pathways in Parkinson's disease. Neurochem Res 34:55-65.

Morale MC, Serra PA, L'Episcopo F, Tirolo C, Caniglia S, Testa N, Gennuso F, Giaquinta G, Rocchitta G, Desole MS, et al. 2006. Estrogen, neuroinflammation and neuroprotection in Parkinson's disease: Glia dictates resistance versus vulnerability to neurodegeneration. Neuroscience 138:869-878.

Nakagawa T, Schwartz JP. 2004. Gene expression profiles of reactive astrocytes in dopamine-depleted striatum. Brain Pathol 14:275-280.

Olesen BT, Clausen J, Vang O. 2008. Characterization of the transcriptional profile in primary astrocytes after oxidative stress induced by Paraquat. NeuroToxicol 29:13-21.

Ordonez C, Navarro A, Perez C, Astudillo A, Martinez E, Tolivia J. 2006. Apolipoprotein D expression in substantia nigra of Parkinson disease. Histol Histopathol 21:361-366.

Ortmann R, Perkins JP. 1977. Stimulation of adenosine $3^{\prime}: 5^{\prime}$-monophosphate formation by prostaglandins in human astrocytoma cells. Inhibition by nonsteroidal anti-inflammatory agents. J Biol Chem 252:6018-6025.

Pallast S, Arai K, Wang X, Lo EH, Van Leyen K. 2009. 12/15-Lipoxygenase targets neuronal mitochondria under oxidative stress. J Neurochem 111:882-889.

Pekny M, Nilsson M. 2005. Astrocyte activation and reactive gliosis. Glia 50:427-434.

Peng J, Mao XO, Stevenson FF, Hsu M, Andersen JK. 2004. The herbicide paraquat induces dopaminergic nigral apoptosis through sustained activation of the JNK pathway. J Biol Chem 279:32626-32632.

Perea G, Navarrete M, Araque A. 2009. Tripartite synapses: Astrocytes process and control synaptic information. Trends Neurosci 32:421431.

Pocivavsek A, Rebeck GW. 2009. Inhibition of c-Jun N-terminal kinase increases apoE expression in vitro and in vivo. Biochem Biophys Res Commun 387:516-520.

Poirier J. 2005. Apolipoprotein E, cholesterol transport and synthesis in sporadic Alzheimer's disease. Neurobiol Aging 26:355-361. 
Prasad K, Tarasewicz E, Mathew J, Strickland PAO, Buckley B, Richardson JR, Richfield EK. 2009. Toxicokinetics and toxicodynamics of paraquat accumulation in mouse brain. Exp Neurol 215:358367.

Prasad K, Winnik B, Thiruchelvam M, Buckley B, Mirochnitchenko O, Richfield E. 2007. Prolonged toxicokinetics and toxicodynamics of paraquat in mouse brain. Environ Health Perspect 115:1448-1453.

Renau-Piqueras J, Zaragoza R, De Paz P, Baguena-Cervellera R, Megias L, Guerri C. 1989. Effects of prolonged ethanol exposure on the glial fibrillary acidic protein-containing intermediate filaments of astrocytes in primary culture: A quantitative immunofluorescence and immunogold electron microscopic study. J Histochem Cytochem 37:229-240.

Rossi D, Volterra A. 2009. Astrocytic dysfunction: Insights on the role in neurodegeneration. Brain Res Bull 80(4-5):224-232.

Ruiz M, Sanchez D, Canal I, Acebes A, Ganfornina MD. 2011. Sexdependent modulation of longevity by two Drosophila homologues of human Apolipoprotein D, GLaz and NLaz. Exp Gerontol 46:579589.

Sanchez D, Lopez-Arias B, Torroja L, Canal I, Wang X, Bastiani MJ, Ganfornina MD, Walker DW, Muffat J, Rundel C, et al. 2006. Loss of glial lazarillo, a homolog of apolipoprotein D, reduces lifespan and stress resistance in Drosophila. Curr Biol 16:680-686.

Sarjeant JM, Lawrie A, Kinnear C, Yablonsky S, Leung W, Massaeli H, Prichett W, Veinot JP, Rassart E, Rabinovitch M. 2003. Apolipoprotein D inhibits platelet-derived growth factor-BB-induced vascular smooth muscle cell proliferated by preventing translocation of phosphorylated extracellular signal regulated kinase $1 / 2$ to the nucleus. Arterioscler Thromb Vasc Biol 23:2172-2177.

Shepherd KR, Lee E-SY, Schmued L, Jiao Y, Ali SF, Oriaku ET, Lamango NS, Soliman KFA, Charlton CG. 2006. The potentiating effects of 1-methyl-4-phenyl-1,2,3,6-tetrahydropyridine (MPTP) on paraquat-induced neurochemical and behavioral changes in mice. Pharmacol Biochem Behav 83:349-359.

Silva R, Mata L, Gulbenkian S, Brites D. 2001. Endocytosis in rat cultured astrocytes is inhibited by unconjugated bilirubin. Neurochem Res 26:793-800.

Sofroniew MV. 2009. Molecular dissection of reactive astrogliosis and glial scar formation. Trends Neurosci 32:638-647.

Song YJC, Halliday GM, Holton JL, Lashley T, O'Sullivan SnS, McCann H, Lees AJ, Ozawa T, Williams DR, Lockhart PJ, et al. 2009. Degeneration in different parkinsonian syndromes relates to astrocyte type and astrocyte protein expression. J Neuropathol Exp Neurol 68:1073-1083.
Takuma K, Baba A, Matsuda T. 2004. Astrocyte apoptosis: Implications for neuroprotection. Progress Neurobiol 72:111-127.

Terrisse L, Seguin D, Bertrand P, Poirier J, Milne R, Rassart E. 1999 Modulation of apolipoprotein D and apolipoprotein E expression in rat hippocampus after entorhinal cortex lesion. Brain Res Mol Brain Res 70:26-35.

Thiruchelvam M, Richfield EK, Baggs RB, Tank AW, Cory-Slechta DA 2000. The nigrostriatal dopaminergic system as a preferential target of repeated exposures to combined paraquat and Maneb: Implications for Parkinson's disease. J Neurosci 20:9207-9214.

Thomas EA, George RC, Sutcliffe JG. 2003. Apolipoprotein D modulates arachidonic acid signaling in cultured cells: Implications for psychiatric disorders. Prostaglandins Leukotrienes Essential Fatty Acids 69:421-427.

Van Dijk W, Do Carmo S, Rassart E, Dalhlback B, Sodetz J. 2006. The plasma lipocalins $\alpha_{1}$-acid glycoprotein, apolipoprotein $\mathrm{D}$, apolipoprotein $\mathrm{M}$ and complement C8 $\gamma$. In: Akerstrom B, Borregaard N, Flower D, Salier J, editors. Lipocalins. Georgetown, Texas: Landes Bioscience. pp140-166.

Villadiego J, Mendez-Ferrer S, Valdes-Sanchez T, Silos-Santiago I, Farinas I, Lopez-Barneo J, Toledo-Aral JJ. 2005. Selective glial cell linederived neurotrophic factor production in adult dopaminergic carotid body cells in situ and after intrastriatal transplantation. J Neurosci 25:4091-4098.

Walker DW, Muffat J, Rundel C, Benzer S. 2006. Overexpression of a drosophila homolog of apolipoprotein D leads to increased stress resistance and extended lifespan. Curr Biol 16:674-679.

Wang J, Duhart HM, Xu Z, Patterson TA, Newport GD, Ali SF. 2008 Comparison of the time courses of selective gene expression and dopaminergic depletion induced by MPP+ in MN9D cells. Neurochem Int 52:1037-1043.

Wang X, Zaidi A, Pal R, Garrett AS, Braceras R, Chen XW, Michaelis ML, Michaelis EK. 2009. Genomic and biochemical approaches in the discovery of mechanisms for selective neuronal vulnerability to oxidative stress. BMC Neurosci 10:12.

Yan LJ, Levine RL, Sohal RS. 1997. Oxidative damage during aging targets mitochondrial aconitase. Proc Natl Acad Sci USA 94:1116811172 .

Zhang Y, Cong Y, Wang S, Zhang S. 2010. Antioxidant activities of recombinant amphioxus (Branchiostoma belcheri) apolipoprotein D. Mol Biol Rep1-5.

Zheng LT, Lee S, Yin GN, Mori K, Suk K. 2009. Down-regulation of lipocalin 2 contributes to chemoresistance in glioblastoma cells. J Neurochem 111:1238-1251. 

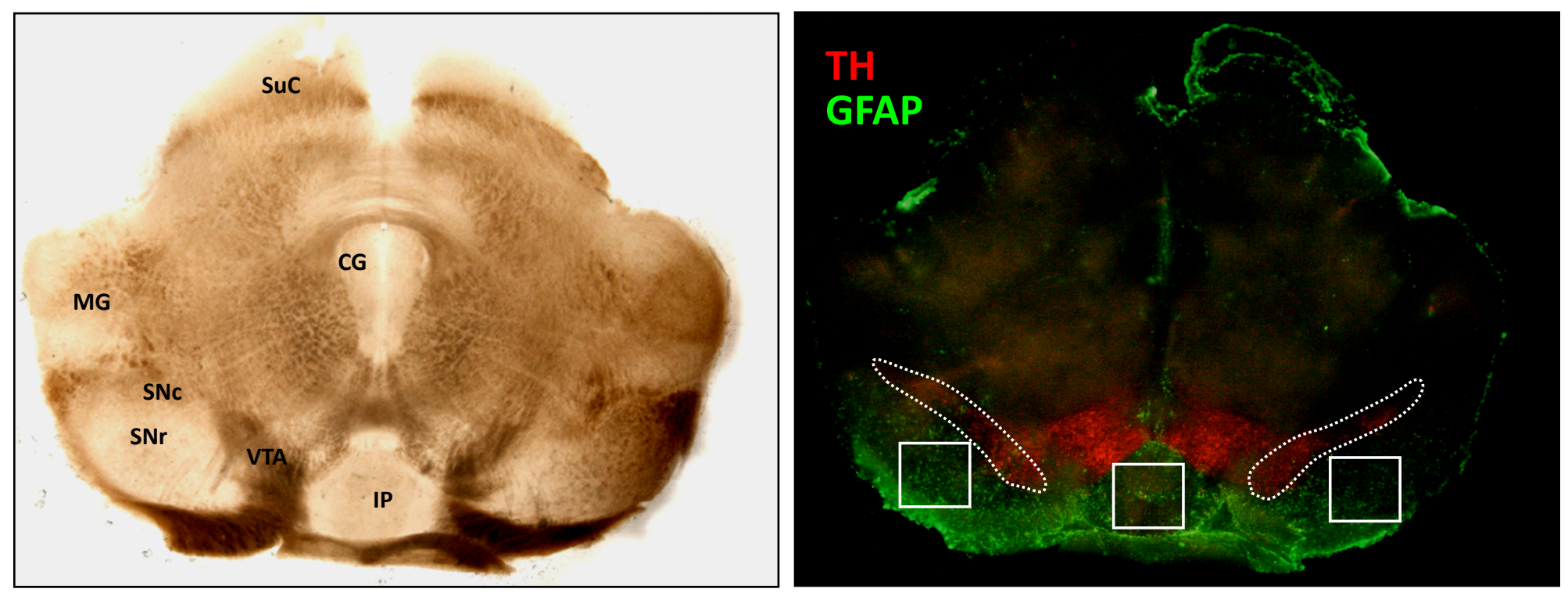

Fig. S1. Mesencephalic regions analyzed to evaluate SNc dopaminergic neuronal cell death and astroglial reactivity. Coronal slices $(200 \mu \mathrm{m})$ including the regions of interest were obtained from fresh tissue, fixed and processed as described in the Methods section. The areas outlined in dashed lines were selected in each slice to count the total number of TH-positive neuronal cell bodies. The areas outlined with boxes were selected in each slice for GFAP immunofluorescence quantification. MG, medial geniculate; SuC, superior colliculus; $C G$, central gray; SNC, substantia nigra pars compacta; SNR, substantia nigra pars reticulata; VTA, ventral tegmental area; IP, interpeduncular nucleus. 
A
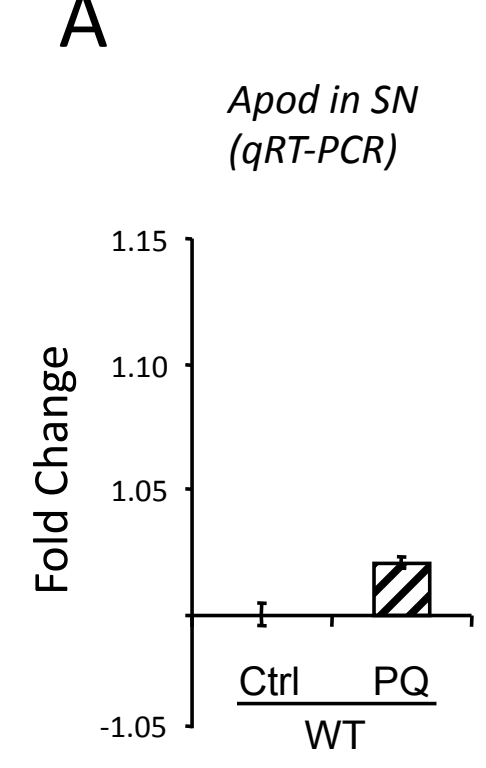

B $\quad \frac{W T}{5 w} \frac{\text { ApoD-KO }}{5 w} \frac{W T}{12 h 12 h}$
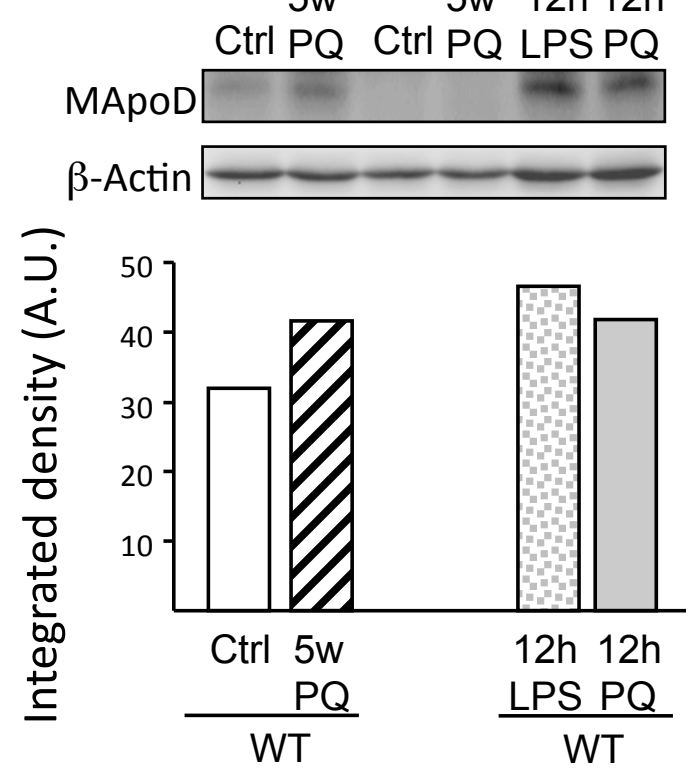

Fig. S2. ApoD protein levels are increased after acute pro-inflammatory and pro-oxidant stimuli, and it is maintained at high levels upon chronic $P Q$ treatment. (A) Immunoblot analysis of ApoD protein levels in striatum. Protein extracts were performed either after 5 weeks of $P Q$ treatment ( $5 \mathrm{w}: 7$ days after the $7^{\text {th }}$ injection at $\left.10 \mathrm{mg} \mathrm{kg}^{-1}\right)$, or $12 \mathrm{~h}$ after a single injection of LPS (3.3 $\left.\mathrm{mg} \mathrm{kg}^{-1}\right)$ or PQ (30 mg kg-1). No ApoD immunoreactivity is detected in the ApoD-KO mice. Protein levels were quantified by band densitometry normalized to $\beta$-actin signal. 
A ApoD time course of expression (qRT-PCR)

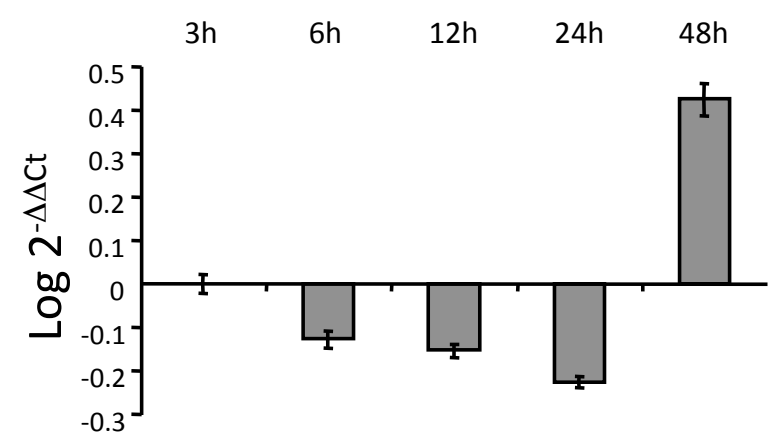

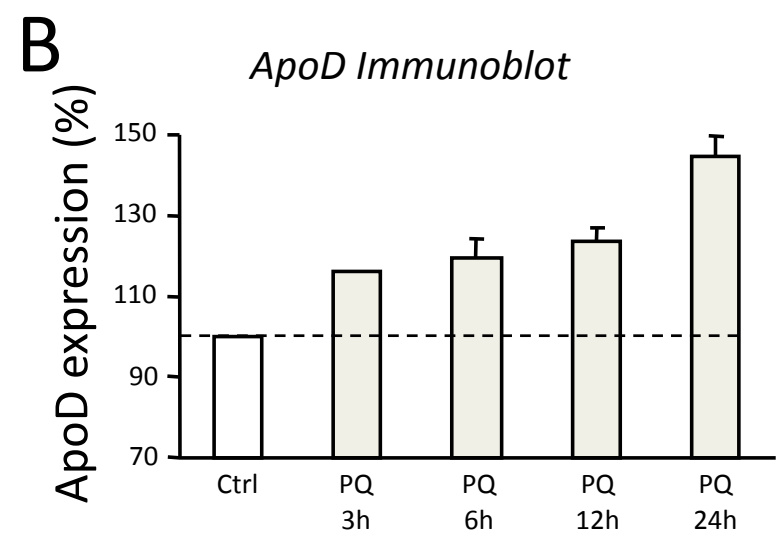

Fig. S3. Time course of hApoD expression in astroglioma 1321N1 cells. (A) ApoD mRNA temporal expression profile in untreated cells measured by qRT-PCR. Time is measured as hours after plating. Confluence is reached at $48 \mathrm{~h}$. Relative amounts with respect to the $3 \mathrm{~h}$ time point (calibrator sample) are shown. (B) Time course of hApoD protein expression upon $\mathrm{PQ}$ exposure measured by immunoblot. Bar graphs show the mean \pm SD of 4 independent experiments. Densitometry values were normalized to $\beta$-actin and shown as percent of control (untreated cells) value. 
Figure S4

A

Apoptosis assay (TUNEL)
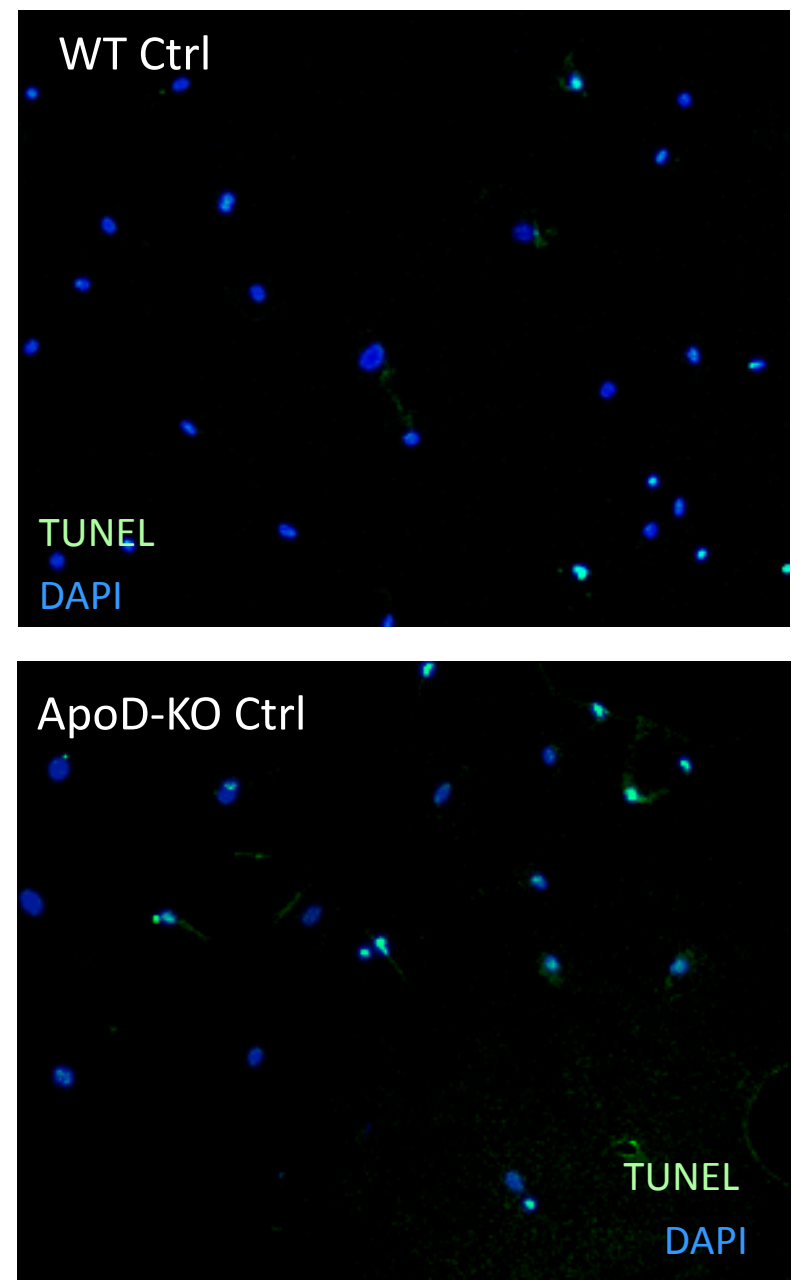

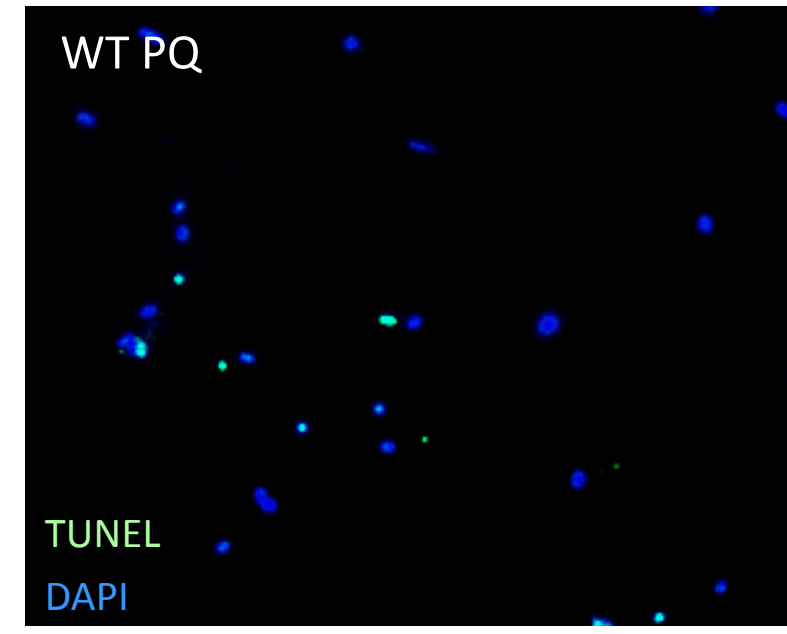

ApoD-KO PQ

B

Positive control Macrophages + DNasel

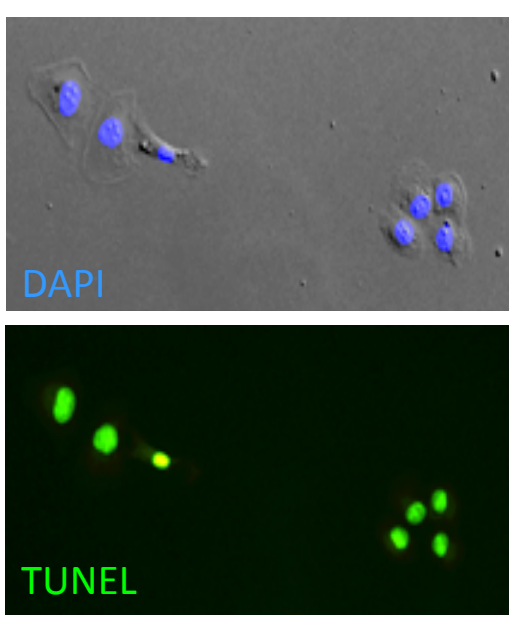

C

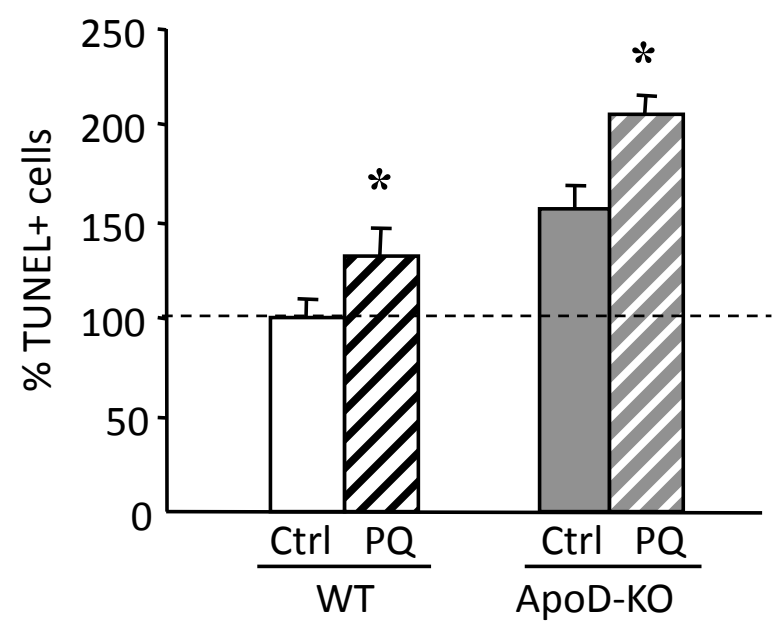

Fig. S4. Apoptotic cell death is increased in ApoD-KO primary astrocytes. (A) Representative low magnification fluorescence images after TUNEL assay. Apoptotic nuclei are shown in pale green. Nonapoptotic nuclei are labeled in deep blue by DAPI. (B) Positive control performed in primary macrophages after treating cells with DNAsel. (C) Quantification of percentage of TUNEL-positive cells in 10 optic fields (10x objective) per genotype and condition. Data represented as mean \pm SD. Statistical differences assayed by Student's t-test, $* p<0.05$. 
Figure S5

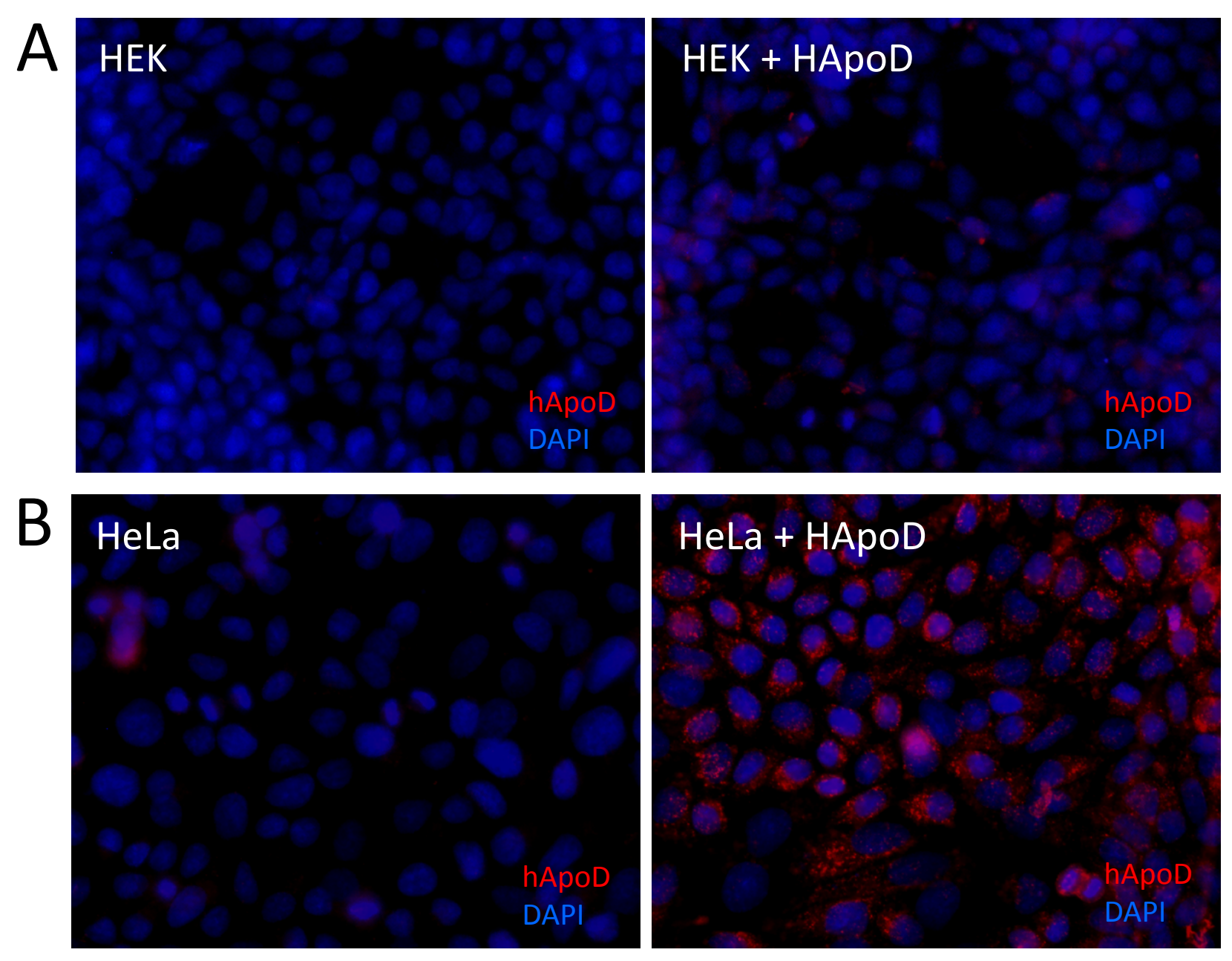

Fig. S5. Internalization of hApoD into cells is not due unspecific endocytosis. (A) Immunoreactivity against $h A p o D$ is not detected in the HEK cell line after addition of $4 \mathrm{nM}$ hApoD for $24 \mathrm{~h}$. (B) HeLa cells, however, do internalize hApoD after the same treatment. 

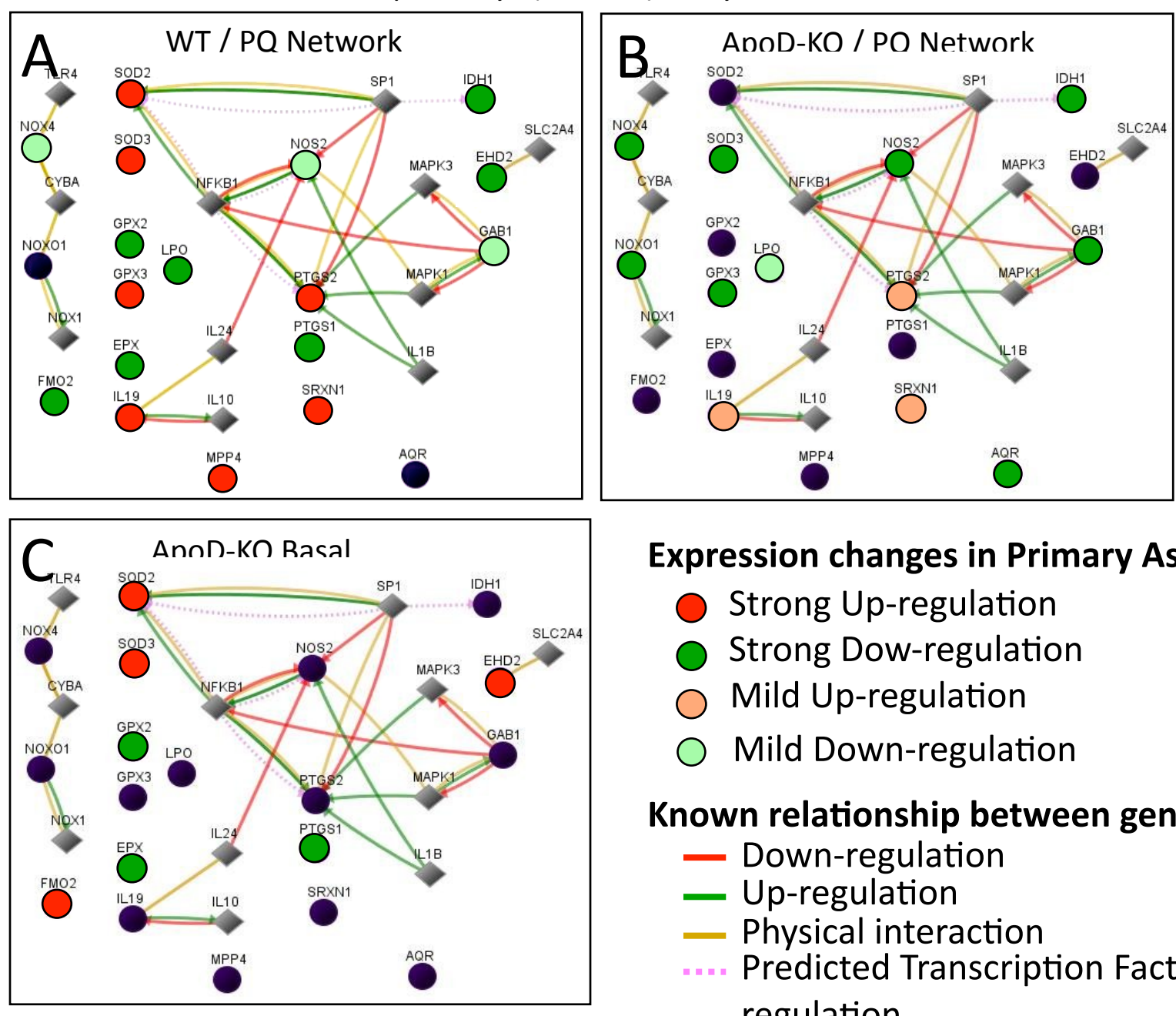

\section{Expression changes in Primary Astrocytes}

Strong Up-regulation

Strong Dow-regulation

Mild Up-regulation

Mild Down-regulation

\section{Known relationship between genes}

- Down-regulation

- Up-regulation

- Physical interaction

.... Predicted Transcription Factor regulation

Fig. S6. Gene pathway analysis of the ApoD-dependent subsets of anti-oxidant responsive genes performed with Gene Network Central Pro ${ }^{\mathrm{TM}}$ (http://gncpro.sabiosciences.com). (A-B) Relationships among genes showing differential response to $P Q$ treatment between WT and ApoD-KO astrocytes. (C) Relationships among genes with significantly different basal levels of expression in ApoD-KO mice. Circles represent genes whose expression has been measured in our qRT-PCR array. Diamonds represent genes with regulatory or physical interactions with the assayed genes. 
Table S1

\begin{tabular}{|l|r|}
\hline & \multicolumn{1}{|c|}{ WT } \\
\hline & Fold change \\
\hline II19 & \multicolumn{1}{|c|}{$462.08 \pm 83.60$} \\
\hline Ptgs2 & $70.88 \pm 6.65$ \\
\hline Txnrd1 & $22.74 \pm 1.66$ \\
\hline Duox1 & $11.06 \pm 1.30$ \\
\hline Srxn1 & $8.22 \pm 1.13$ \\
\hline Xirp1 & $4.00 \pm 1.03$ \\
\hline Sod2 & $3.62 \pm 0.79$ \\
\hline Tmod1 & $2.92 \pm 0.31$ \\
\hline Zmynd17 & $2.77 \pm 0.46$ \\
\hline Gpx3 & $2.34 \pm 0.17$ \\
\hline Sod3 & $2.32 \pm 0.53$ \\
\hline Mpp4 & $2.31 \pm 0.45$ \\
\hline Ehd2 & $-2.21 \pm 0.11$ \\
\hline Ccs & $-2.44 \pm 1.56$ \\
\hline Prdx4 & $-2.55 \pm 0.26$ \\
\hline Nudt15 & $-2.67 \pm 0.28$ \\
\hline Dnm2 & $-2.83 \pm 0.32$ \\
\hline Idh1 & $-2.83 \pm 0.18$ \\
\hline Epx & $-2.88 \pm 0.46$ \\
\hline Gstk1 & $-3.24 \pm 0.35$ \\
\hline Tpo & $-3.25 \pm 0.97$ \\
\hline Ctsb & $-3.32 \pm 0.28$ \\
\hline Apole & $-3.42 \pm 0.20$ \\
\hline Recql4 & $-3.45 \pm 1.19$ \\
\hline Slc41a3 & $-3.46 \pm 0.24$ \\
\hline Slc38a1 & $-3.54 \pm 0.22$ \\
\hline Kif9 & $-3.96 \pm 0.46$ \\
\hline Gpx2 & $-5.08 \pm 1.61$ \\
\hline Ift172 & $-5.29 \pm 0.69$ \\
\hline Nox1 & $-5.39 \pm 1.77$ \\
\hline Lpo & $-5.78 \pm 1.15$ \\
\hline Cyba & $-6.40 \pm 0.56$ \\
\hline Aass & $-15.29 \pm 4.12$ \\
\hline Ncf2 & $-17.84 \pm 1.62$ \\
\hline Txnip & $-22.79 \pm 2.51$ \\
\hline Fmo2 & $-25.79 \pm 2.40$ \\
\hline Ptgs1 & $-70.85 \pm 16.12$ \\
\hline
\end{tabular}

Table S1. Gene expression changes to $P Q$ treatment in WT primary astrocyte cultures. Fold change (FC) with respect to untreated cultures is listed (mean \pm SD of 4 replicas). All cases are statistically supported (MannWhitney's U-test, $p<0.05)$ and have a FC $>2$. 



\subsection{A Protective effects of ApoD against oxidative stress on dopaminergic neurons modeling Parkinson's disease in vitro (Objective 3).}

This objective aimed at testing whether $A p o D$ has an impact on the vulnerability of dopaminergic neurons in vitro, and particularly in a model of Parkinson's disease generated by loss of function of PINK1 gene (one of the relevant genes involved in the pathogenesis of familial Parkinson's disease).

The results obtained are still in preparation and have been conducted in Dr. Angel Cedazo-Minguez laboratory, supervisor of my short stay at Karolinska Institut, Stockholm, Sweden, as part of my predoctoral education.

With this objective we want to solve if the beneficial effects that ApoD exert on the functionality and vulnerability of dopaminergic systems is a direct protecting effect on neurons, an effect mediated by glial cells, or a combination of both.

To check whether ApoD can really have a direct effect on dopaminergic neurons we measured viability of human neuroblastoma cells (BE (2)-M17, or $M 17$ ) treated with exogenous $h A p o D$ and $P Q$, using a paradigm similar to the one used for astrocytes. In addition, we used a model of M17 cells deficient in PINK1 protein (PINK1-KD or PINK1-Knock-Down), which is involved in maintaining mitochondrial function and protecting against oxidative stress.

The results show an improvement in M17 cell viability and PINK1-KD cells treated with $P Q$ in combination with exogenous addition of human ApoD. Furthermore, we found that at least part of the beneficial effect of $A p o D$ in these cells might be due to the activation of ERK pathway, one of the cellular cascades that promote survival. 
Overall, we can state that $A p o D$ is involved in maintaining the homeostasis of the nervous system acting at different levels and on different cell types in oxidative stress situations. As part of the early response to stress, ApoD in turn regulates signaling and transcriptional responses in both glia and neurons. Later, ApoD works by preventing the accumulation of pro-oxidant adducts (lipid peroxides) that originate upon stress. ApoD protective effects on neurons are sufficient even when neurons have deleterious genetic alterations that model, at least in part, the etiology of Parkinson's disease. 


\subsection{B Efectos protectores de ApoD frente al estrés oxidativo sobre neuronas dopaminérgicas que modelan in vitro la enfermedad de Parkinson (Objetivo 3).}

Este objetivo consistía en comprobar si ApoD tiene un impacto en la vulnerabilidad de neuronas dopaminérgicas, así como en un modelo in vitro de la enfermedad de Parkinson que consiste en la pérdida de función del gen PINK1, uno de los genes relevantes en la patogenia del Parkinson familiar.

Los resultados relativos a este objetivo están aún en preparación y se han llevado a cabo en el laboratorio del Dr. Angel Cedazo, tutor de mi estancia en el Karolinska Institute, Estocolmo, Suecia, como parte de mi educación predoctoral.

Con este objetivo nos preguntamos si el efecto beneficioso que desempeña ApoD sobre la funcionalidad y la vulnerabilidad del sistema dopaminérgico es un efecto directo de protección sobre la neurona, si el efecto se realiza a través de la glía, o si es la conjunción de ambos.

Para comprobar si verdaderamente ApoD puede ejercer un efecto directo sobre las neuronas dopaminérgicas, llevamos a cabo experimentos de viabilidad, semejantes a los realizados para astrocitos en cultivo, sobre células de neuroblastoma humano (BE(2)-M17, o M17) tratadas con hApoD y $P Q$. Además, hemos usado un modelo de células M17 con deficiencia en la proteína PINK1 (PINK1-KD o PINK1-Knock-Down), implicada en el mantenimiento de la función mitocondrial y en la protección frente al estrés oxidativo.

Los resultados obtenidos muestran una mejora en la viabilidad de las células M17 y las células PINK1-KD sometidas a estrés oxidativo cuando son tratadas con ApoD humana de manera exógena. Además, pudimos comprobar que este efecto beneficioso que ejerce ApoD sobre estas células 
puede ser debido a la activación la vía de ERK, una de las cascadas celulares que promueven la supervivencia.

En conjunto podemos afirmar que ApoD participa en el mantenimiento de la homeostasis del sistema nervioso actuando a varios niveles y sobre diferentes tipos celulares ante una situación de estrés oxidativo. Como parte de la respuesta temprana al estrés, ApoD regula a su vez la respuesta transcripcional y señalizadora tanto en la glía como en las neuronas, y posteriormente actúa evitando la acumulación de productos pro-oxidantes (lípidos peroxidados) originados como consecuencia de dicho estrés. Los efectos protectores sobre las neuronas son suficientes incluso cuando las neuronas tienen alteraciones genéticas deletéreas que modelan, al menos en parte, la etiología del Parkinson. 


\subsection{Efectos protectores de ApoD frente al estrés oxidativo sobre neuronas dopaminérgicas que modelan in vitro la enfermedad de Parkinson.}

Para comprobar si verdaderamente ApoD puede ejercer un efecto directo sobre neuronas dopaminérgicas, llevamos a cabo experimentos de viabilidad, semejantes a los realizados para astrocitos, en una línea celular de neuronas dopaminérgicas humanas provenientes de un neuroblastoma (BE(2)-M17, o M17) tratadas con hApoD y PQ. Los protocolos de cultivos celulares, de adición de los diferentes estímulos, y de medida de la viabilidad celular siguen la metodología descrita en el trabajo publicado y presentado en la sección 4.2. con la peculiaridad de que estas células se cultivan en un medio diferente (OptiMEM suplementado con 10\% de FBS (Fetal Bovine Serum) y $1 \%$ de L-Glutamina (L-Gln). Para diferenciarlas, se añade al medio un tratamiento con ácido retinoico $(10 \mu \mathrm{M})$ durante una semana (refrescando el medio con ácido retinoico cada 3 días) seguido de un tratamiento con BDNF $(0,1 \mathrm{ng} / \mathrm{ml})$ durante 7 días. Transcurrido este periodo de diferenciación, las neuronas se encuentran listas para comenzar los experimentos.

4.3.1. La adición exógena de ApoD mejora la viabilidad de neuronas dopaminérgicas ante la exposición a PQ.

Hemos comprobado que $h A p o D$, a la misma concentración que la usada en astrocitos primarios (4 $\mathrm{nM})$, mejora la supervivencia de células de neuroblastoma tratadas con $\mathrm{PQ}(500 \mu \mathrm{M})$ durante el mismo tiempo de estimulación (24 horas) (Figura 4-1).

Cuando realizamos una medida de la viabilidad usando un tratamiento más corto (15 horas) observamos una tendencia de mejora en la viabilidad, pero no se consigue reproducir la misma intensidad de daño sobre las células (Figura 4-2). 


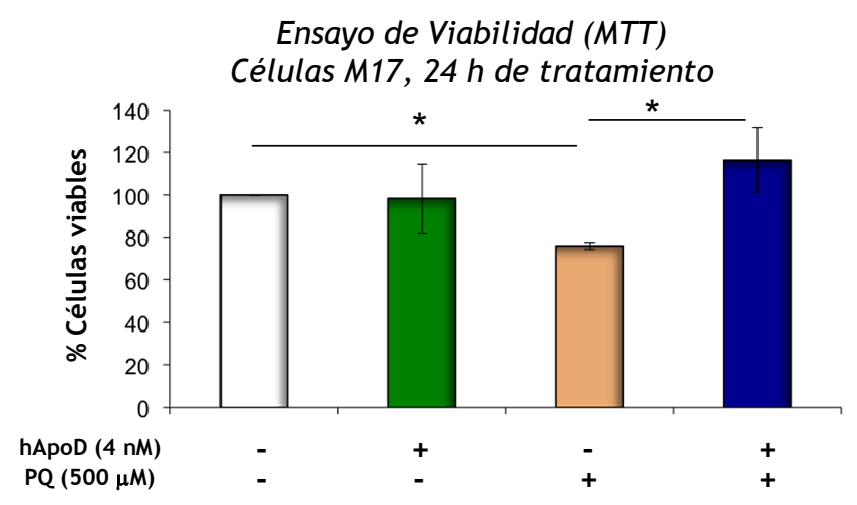

Fig. 4-1. La adición de ApoD humana ( $h A p o D)$ mejora la supervivencia de células dopaminérgicas de neuroblastoma M17 ante el tratamiento con PQ. ApoD (4 nM) y $P Q(500 \mu \mathrm{M})$ fueron añadidos de forma simultánea a los cultivos, tras 12 horas de retirada del suero en el medio de cultivo. Porcentaje de supervivencia en 24 horas de tratamiento cuantificado mediante un ensayo colorimétrico de viabilidad (ensayo MTT). Los asteriscos señalan diferencias significativas (test de T-Student, $p<0,05)$. El análisis estadístico se llevó a cabo con los datos de tres experimentos independientes en cada uno de los cuales la medida se realizó por triplicado.

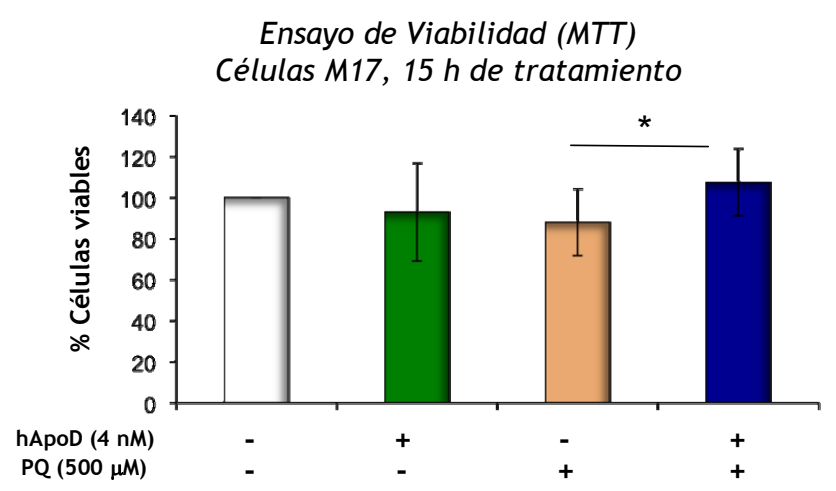

Fig. 4-2. Los efectos debidos a la adición de ApoD humana (hApoD) son menos distinguibles cuando el tratamiento de las células con PQ es mas corto (15 horas). Se aprecia una mejora en la viabilidad sobre la viabilidad basal. Células dopaminérgicas de neuroblastoma M17. ApoD (4 nM) y PQ $(500 \mu \mathrm{M})$ fueron añadidos de forma simultánea a los cultivos, tras 12 horas de retirada del suero en el medio de cultivo. Porcentaje de supervivencia cuantificado mediante un ensayo colorimétrico de viabilidad (ensayo MTT). Los asteriscos señalan diferencias significativas (test de T-Student, $p<0,05$ ). El análisis estadístico se llevó a cabo con los datos de tres experimentos independientes en cada uno de los cuales la medida se realizó por triplicado.

Tras haber observado un efecto protector de ApoD sobre las células dopaminérgicas M17, nos preguntamos si el efecto protector de ApoD sería 
también efectivo si las células carecen de la proteína PINK1 (PINK1 KnockDown o PINK1-KD). Varias mutaciones en esta proteína se asocian con la enfermedad de Parkinson, ya que PINK1 es una proteína implicada en el mantenimiento de la función mitocondrial y en la protección frente al estrés oxidativo. PINK1 a su vez, controla a Parkina, ambas asociadas con el Parkinson familiar ${ }^{1}$. Las células PINK1-KD son células M17 establemente transfectadas con un constructo que consiste en un ARN de interferencia, un shRNA (del inglés: short hairpin RNA) del ADNc del gen PINK1 humano, que reduce la expresión del gen. Para el mantenimiento de esta línea se utiliza una selección negativa mediante un antibiótico (blasticidina), ya que el vector que contiene el shRNA lleva un "cassette" resistencia para dicho antibiótico. En todos los casos en los que se usa este tipo celular se añade blasticidina al medio de cultivo $(5 \mu \mathrm{g} / \mathrm{ml})^{2,3}$.

En las células deficientes en PINK1 observamos que la recuperación de la viabilidad causada por hApoD (4 nM) tras el tratamiento con PQ (500 $\mu \mathrm{M}$, durante 24 horas) es incluso mejor que en las M17 no transfectadas (Figura 4-3). Se ha descrito que las células deficientes en PINK1 tienen mayores niveles de ROS y de lípidos peroxidados, pero que también tienen mayores niveles de antioxidantes en respuesta a ese aumento de estrés ${ }^{4}$. Dado que estas células están basalmente sometidas a estrés oxidativo, ApoD exógena proporciona una ayuda extra posiblemente actuando no a nivel mitocondrial, pero si en las fases finales de la cascada de eventos que se desencadenan con el paraquat como la retirada de lípidos peroxidados. Este efecto es muy similar al descrito anteriormente en los astrocitos (apartado 4.2. de resultados).

El efecto que tiene la hApoD sobre la viabilidad de las células deficientes en PINK1 no es tan apreciable cuando estas células están sujetas a tratamientos con $\mathrm{PQ}$ y ApoD más cortos (PQ $500 \mu \mathrm{M}$ durante 15 horas) dado que el efecto del $P Q$ es de por sí débil (Figura 4-4). Aun así, las tendencias observadas en ambos experimentos de $15 \mathrm{~h}$ (Figuras 4-2 y 4-4) nos indican que la acción 
neuroprotectora que realiza $A p o D$ debe tener lugar en las primeras etapas tras la aplicación del estímulo estresante.

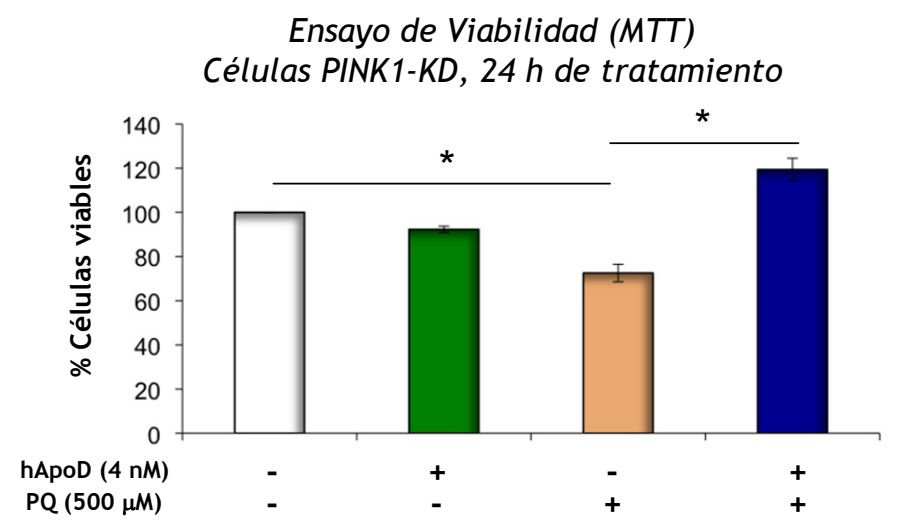

Fig. 4-3. La adición exógena de ApoD humana (hApoD) mejora la supervivencia de células dopaminérgicas de neuroblastoma M17 deficientes en PINK1 (PINK1$\mathrm{KD})$ ante el tratamiento con $\mathrm{PQ}$. ApoD $(4 \mathrm{nM})$ y $\mathrm{PQ}(500 \mu \mathrm{M})$ fueron añadidos de forma simultánea a los cultivos, tras 12 horas de retirada del suero en el medio de cultivo. Porcentaje de supervivencia en 24 horas de tratamiento cuantificado mediante un ensayo colorimétrico de viabilidad (ensayo MTT). Los asteriscos señalan diferencias significativas (test de T-Student, $p<0,05$ ). El análisis estadístico se llevó a cabo con los datos de tres experimentos independientes en cada uno de los cuales la medida se realizó por triplicado.

Ensayo de Viabilidad (MTT) Células PINK1-KD, $15 \mathrm{~h}$ de tratamiento

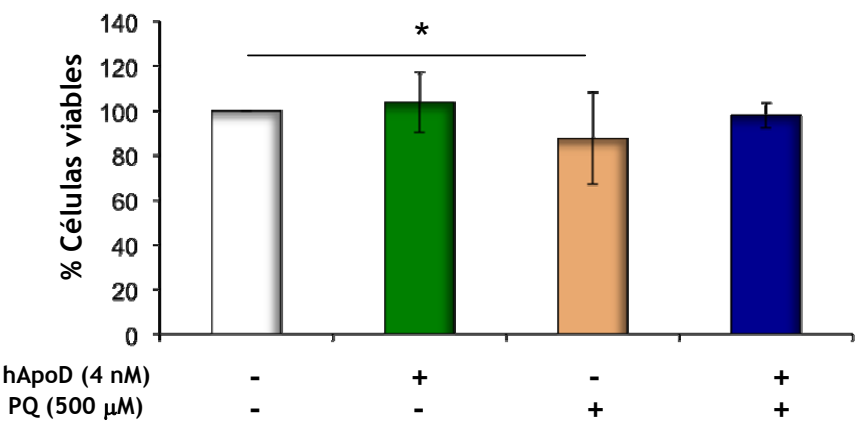

Fig.4-4. Los efectos debidos a la adición de ApoD humana ( $h A p o D)$ son menos distinguibles cuando el tratamiento de las células M17 deficientes en PINK1 (PINK1-KD) con PQ es mas corto (15 horas). Se aprecia una mejora en la viabilidad sobre la viabilidad basal. Células dopaminérgicas de neuroblastoma M17. ApoD (4 nM) y $P Q(500 \mu M)$ fueron añadidos de forma simultánea a los cultivos, tras 12 horas de retirada del suero en el medio de cultivo. Porcentaje de supervivencia cuantificado mediante un ensayo colorimétrico de viabilidad (ensayo MTT). Los asteriscos señalan diferencias significativas (test de T-Student, $p<0,05$ ). 
El análisis estadístico se llevó a cabo con los datos de tres experimentos independientes en cada uno de los cuales la medida se realizó por triplicado.

4.3.2. La adición exógena de ApoD mejora la viabilidad de neuronas dopaminérgicas diferenciadas ante la exposición a $\mathrm{PQ}$

Las células M17, procedentes de un neuroblastoma, se pueden diferenciar hasta obtener un fenotipo de neuronas dopaminérgicas. Éstas pierden su capacidad de proliferación y comienzan a desarrollar neuritas. La diferenciación se lleva a cabo exponiendo el cultivo al factor de crecimiento BDNF durante 2 semanas $^{5}$. Estas células diferenciadas son más vulnerables al estrés oxidativo, por lo que a la hora de reproducir los ensayos de viabilidad celular tras el tratamiento con $P Q$ y hApoD, redujimos los tiempos de exposición. Como resultado preliminar, hemos observado que las células M17 diferenciadas tratadas durante 6 horas con PQ (500 $\mu \mathrm{M})$ y hApoD (4 nM) mejoran su viabilidad (Figura 4-5).

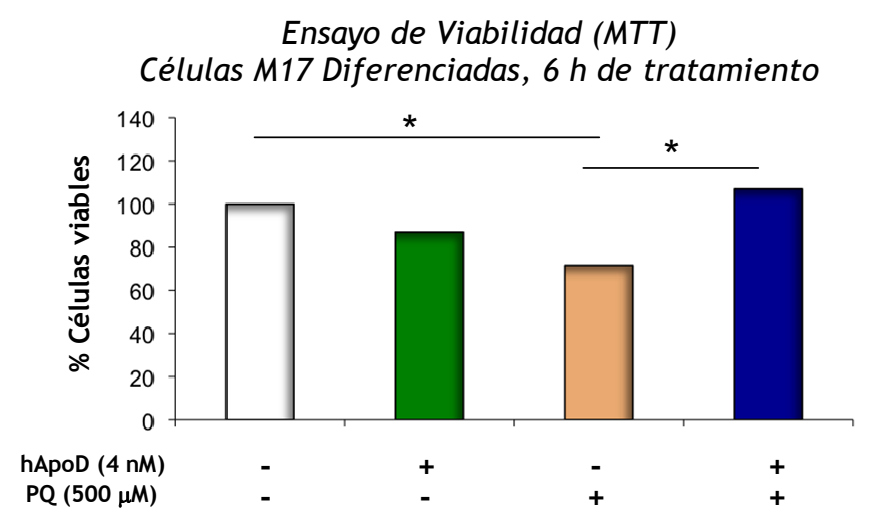

Fig.4-5. Adición exógena de ApoD humana ( $h A p o D)$ mejora la supervivencia de células dopaminérgicas de neuroblastoma M17 diferenciadas (2 semanas con BDNF) ante el tratamiento con PQ. ApoD $(4 \mathrm{nM})$ y $P Q(500 \mu \mathrm{M})$ fueron añadidos de forma simultánea a los cultivos, tras 12 horas de retirada del suero en el medio de cultivo. Porcentaje de supervivencia a las 6 horas de tratamiento cuantificado mediante un ensayo colorimétrico de viabilidad (ensayo MTT). Los asteriscos señalan diferencias significativas respecto a la condición control (test de TStudent, $p<0,05)$. Esta comparación estadística se llevó a cabo con los datos de la medida por triplicado realizada en un único experimento. 
En resumen, hemos comprobado que existe una mejora en la viabilidad de células de neuroblastoma tratadas con hApoD sometidas a estrés oxidativo generado por $P Q$, lo que sugiere que $A p o D$ es una proteína que participa de forma activa en la protección de los sistemas neuronales, además de ejercer un efecto beneficioso sobre las propias células gliales que la producen, como hemos descrito en el apartado 4.2. de resultados.

\subsubsection{La adición exógena de ApoD activa la vía de señalización de ERK}

Estos resultados, aunque preliminares, parecen indicar que el efecto de ApoD debe ser rápido y tal vez mediado por un receptor en la membrana plasmática.

Con esta idea en mente, nos propusimos estudiar si la adición de ApoD activa cascadas de señalización celular relacionadas con la supervivencia celular. Para este objetivo realizamos cultivos de células M17 a las que sometimos a tratamiento con $A p o D$ durante diferentes tiempos. Evaluamos entonces el nivel de activación de la vía de señalización pro-supervivencia de ERK. Exploramos una ventana temporal desde 1 hora hasta 6 horas y pudimos comprobar que tras 3 horas de exposición a ApoD en el medio de cultivo la cantidad relativa de ERK fosforilado ( $p-E R K$ ), frente al nivel de ERK total, comenzaba a aumentar (Figura 4-6). Curiosamente, la activación de ERK tiene lugar de manera más temprana en las células PINK1-KD donde se observa que el aumento de p-ERK comienza desde la primera hora de tratamiento con hApoD exógena.

A pesar de que estos resultados necesitan más comprobaciones y son preliminares, parece claro que $A p o D$ es capaz de activar vías de señalización para la supervivencia celular y que esto se lleva a cabo de una manera rápida, lo que representa una evidencia importante de la existencia de un receptor para $A p o D$, hasta ahora desconocido. 


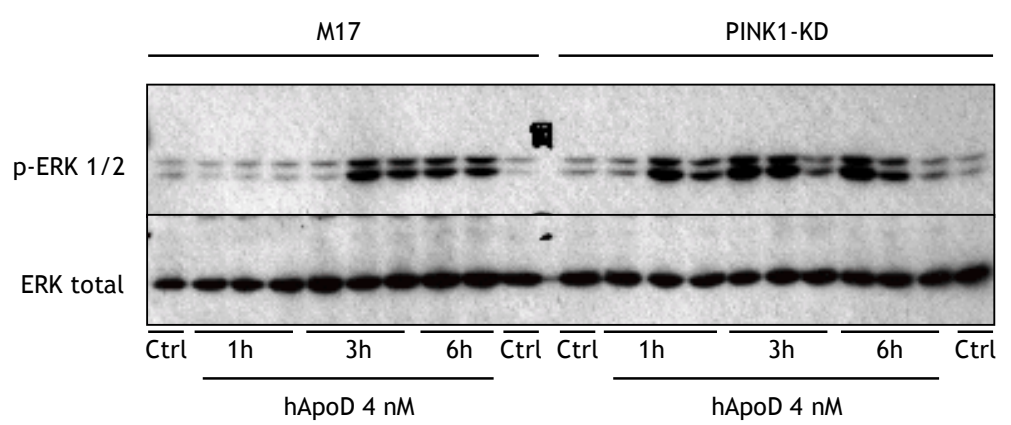

Fig.4-6. Activación de ERK a lo largo del tiempo tras la adición de ApoD humana exógena (hApoD $4 \mathrm{nM}$ ) a células de neuroblastoma M17 y PINK1-KD. El inmunoblot muestra el momento en el que se comienza a activar ERK (ERK fosforilado: $p$-ERK) sin que a penas se modifique la expresión de ERK total. La activación de ERK en las células PINK1-KD es más rápida que en las células M17 no transfectadas, observándose activaciones a una hora del inicio del tratamiento con ApoD exógena. Las adiciones de ApoD exógena fueron realizadas tras 12 horas de retirada del suero en el medio de cultivo. El experimento se realizó por triplicado y las réplicas se muestran de forma independiente.

De la misma forma, habría que hacer más comprobaciones para ahondar en el mecanismo de protección que lleva a cabo ApoD sobre las células dopaminérgicas, tanto en condiciones normales como cuando son deficientes en PINK1. La hipótesis de trabajo que manejamos es que ApoD puede actuar en dos fases diferentes: una de acción rápida mediada por la activación de cascadas de supervivencia como ERK, y posteriormente, a largo plazo, retirando o evitando la formación de lípidos peroxidados que se generan tras un estrés.

\section{Bibliografía}

1. Valente EM, Abou-Sleiman PM, Caputo V, Muqit MM, Harvey $\mathrm{K}$, Gispert S, Ali Z, Del Turco D, Bentivoglio AR, Healy DG, Albanese A, Nussbaum R, Gonzalez-Maldonado R, Deller T, Salvi S, Cortelli P, Gilks WP, Latchman DS, Harvey RJ, Dallapiccola B, Auburger G, Wood NW. Hereditary early-onset Parkinson's disease caused by mutations in PINK1. Science. 2004;304(5674):1158-1160.

2. Sim CH, Lio DS, Mok SS, Masters CL, Hill AF, Culvenor JG, Cheng HC. C-terminal truncation and Parkinson's disease-associated mutations down-regulate the protein serine/threonine kinase activity of PTEN-induced kinase-1. Hum Mol Genet. 2006;15(21):3251-3262. 
3. Exner N, Treske B, Paquet D, Holmstrom K, Schiesling C, Gispert S, Carballo-Carbajal I, Berg D, Hoepken HH, Gasser T, Kruger R, Winklhofer KF, Vogel F, Reichert AS, Auburger G, Kahle PJ, Schmid B, Haass C. Loss-of-function of human PINK1 results in mitochondrial pathology and can be rescued by parkin. $J$ Neurosci. 2007;27(45):12413-12418.

4. Hoepken HH, Gispert S, Morales B, Wingerter O, Del Turco D, Mulsch A, Nussbaum RL, Muller K, Drose S, Brandt U, Deller T, Wirth B, Kudin AP, Kunz WS, Auburger G. Mitochondrial dysfunction, peroxidation damage and changes in glutathione metabolism in PARK6. Neurobiol Dis. 2007;25(2):401-411.

5. Sandebring $A$, Thomas $K J$, Beilina $A$, van der Brug $M$, Cleland $M M$, Ahmad R, Miller DW, Zambrano I, Cowburn RF, Behbahani H, CedazoMinguez A, Cookson MR. Mitochondrial alterations in PINK1 deficient cells are influenced by calcineurin-dependent dephosphorylation of dynamin-related protein 1. PLoS One. 2009;4(5):e5701. 


\subsection{A Expression and possible role of ApoD in the survival I death balance in human colorectal cancer cells under oxidative stress conditions (Objective 4).}

This objective aimed at verifying the changing expression of ApoD along different stages of an aging-related cancer type (colorectal cancer) and to study the coordinated changes in expression of other genes related to the oxidative stress response. With this approach, we want to elucidate if in this situation ApoD is part of the protective response of the tissue.

The results concerning this objective are contained in the manuscript submitted for publication

- Raquel Bajo-Grañeras, Jesús Crespo-Sanjuan, Rosa M GarcíaCenteno, José A Garrote-Adrados, Gabriel Gutierrez, Manuel García-Tejeiro, Beatriz Aguirre-Gervás, María D Calvo-Nieves, Rosa Bustamante, María D Ganfornina, Diego Sanchez

- Expression and potential role of Apolipoprotein $D$ on the deathsurvival balance of human colorectal cancer cells under oxidative stress conditions

- Molecular Oncology, MS\#12-00171

attached below. 


\subsection{B Expresión y posible función de ApoD en el balance supervivencia/muerte en células de cáncer colorrectal humano sujetas a estrés oxidativo (Objetivo 4).}

Este objetivo consistía en verificar el cambio de expresión de ApoD a lo largo de los distintos estadios de un tipo de cáncer asociado al envejecimiento, el cáncer colorrectal, así como estudiar la expresión de otros genes relacionados con el estrés oxidativo, de forma que podamos deducir si en esta patología ApoD se comporta como parte de la respuesta de protección del tejido.

Los resultados relativos a este objetivo están contenidos en el manuscrito enviado para publicación

- Raquel Bajo-Grañeras, Jesús Crespo-Sanjuan, Rosa M GarcíaCenteno, José A Garrote-Adrados, Gabriel Gutierrez, Manuel García-Tejeiro, Beatriz Aguirre-Gervás, María D Calvo-Nieves, Rosa Bustamante, María D Ganfornina, Diego Sanchez

- Expression and potential role of Apolipoprotein $D$ on the deathsurvival balance of human colorectal cancer cells under oxidative stress conditions

- Molecular Oncology, MS\#12-00171

que se adjunta a continuación.

En los anteriores trabajos nos hemos centrado en el sistema nervioso, sin embargo el último de los objetivos que me he planteado era conocer si ApoD tiene funciones protectoras también en células tumorales.

Se había descrito una correlación inversa entre la expresión de ApoD y el crecimiento tumoral, por lo que se ha propuesto a ApoD como un marcador de buen pronóstico de diversos tipos de cáncer, incluido el cáncer colorrectal (CCR). El estrés oxidativo aumenta con el crecimiento del tumor y, como 
hemos visto en las anteriores secciones, la expresión de ApoD se induce ante el estrés oxidativo en muchas situaciones patológicas. Esto representa una paradoja dado que lo que se observa en los tumores es que ApoD baja su expresión.

Para estudiar el papel que juega ApoD en la progresión del cáncer colorrectal humano, hemos analizado muestras de mucosa colónica de pacientes con CCR y muestras de mucosa sana donde hemos medido el nivel de peroxidación lipídica y el perfil de expresión de los genes dependientes de estrés oxidativo. Hemos estudiado además una serie de polimorfismos del gen de ApoD en esta muestra de pacientes y controles. Por último, hemos estudiado los niveles de proliferación y de apoptosis en una línea celular de cáncer de colon (HT-29).

Los resultados obtenidos nos indican que ApoD, tal como esperábamos, disminuye a medida que avanza el estadio de desarrollo tumoral con un máximo de represión en el primer estadio, mientras que los niveles de lípidos peroxidados aumentan progresivamente. Hemos observado que ApoD se expresa de manera normal en la lámina propia de la mucosa, mientras que en el CCR presenta una expresión heterogénea, aumentando de forma específica en determinados tipos celulares (células del epitelio displásico) pero disminuye en el estroma del tumor (explicando así la disminución neta de la expresión).

Además hemos comprobado que la adición exógena de ApoD humana a las células tumorales HT-29 no modifica ni la proliferación ni la apoptosis en situación normal. Sin embargo, al someter estas células a estrés oxidativo y además añadir ApoD aumentan significativamente los niveles de apoptosis. Hemos comprobado que las HT-29 conservan la capacidad de inducir la expresión de ApoD al someterlas a estrés oxidativo, incluso aunque su expresión esté basalmente reprimida por metilación del DNA.

Todos estos resultados nos muestran que ApoD es un gen de respuesta a estrés incluso en el microambiente tumoral y que puede usarse como 
marcador de los primeros estadios de progresión tumoral. Al promover la apoptosis de células tumorales en condiciones pro-oxidantes podría convertirse en una herramienta terapéutica para promover la muerte de las células tumorales proliferativas cuando están sufriendo estrés oxidativo durante el desarrollo del tumor. 


\section{Elsevier Editorial System(tm) for Molecular Oncology}

Manuscript Draft

Manuscript Number: 12-00171

Title: Expression and potential role of Apolipoprotein D on the death-survival balance of human colorectal cancer cells under oxidative stress conditions

Article Type: Research Paper

Keywords: lipocalin, oxidative stress, proliferation, apoptosis, lipid peroxidation

Corresponding Author: Dr. Diego Sanchez, Ph.D.

Corresponding Author's Institution: Universidad de Valladolid

First Author: Raquel Bajo-Grañeras, MS

Order of Authors: Raquel Bajo-Grañeras, MS; Jesús Crespo-Sanjuan, MD; Rosa M García-Centeno, Technician; José A Garrote-Adrados, PhD; Gabriel Gutierrez, PhD; Manuel García-Tejeiro, MD; Beatriz Aguirre-Gervás, MD; María D Calvo-Nieves, MD; Rosa Bustamante, MD; María D Ganfornina, PhD; Diego Sanchez, Ph.D.

Abstract: Inverse correlations of Apolipoprotein D (ApoD) expression with tumor growth have been shown, therefore proposing ApoD as a good prognostic marker for diverse cancer types, including colorectal cancer (CRC). Besides, ApoD expression is boosted upon oxidative stress (OS) in many pathological situations. This study aims at understanding the role of ApoD in the progression of human CRC. Samples of CRC and distant normal tissue $(n=51)$ were assayed for levels of lipid peroxidation, expression profile of OS-dependent genes, and protein expression. Three single-nucleotidepolymorphisms in the ApoD gene were analyzed $(n=139)$, with no significant associations found. Finally, we assayed the effect of ApoD in proliferation and apoptosis in the CRC HT-29 cell line. In CRC, lipid peroxides increase while ApoD mRNA and protein decrease through tumor progression, with a prominent decrease in stage I. In normal mucosa ApoD protein is present in lamina propia and enteroendocrine cells. In CRC ApoD expression is heterogeneous, with low expression in stromal cells and high expression in the dysplastic epithelium. ApoD promoter is basally methylated in HT-29 cells, but it retains the ability to respond to OS. Exogenous addition of ApoD to HT-29 cells does not modify proliferation or apoptosis levels in control conditions, but it promotes apoptosis upon paraquatinduced OS. Our results show ApoD as a gene responding to OS in the tumor microenvironment. Besides using ApoD as marker of initial stages of tumor progression, it can become a therapeutic tool promoting death of proliferating tumor cells suffering OS. 


\section{Expression and potential role of Apolipoprotein D on the death- survival balance of human colorectal cancer cells under oxidative stress conditions}

Raquel BAJO-GRAÑERAS, Jesús CRESPO SANJUAN, Rosa M. GARCÍA CENTENO, José Antonio GARROTE-ADRADOS, Gabriel GUTIERREZ, Manuel GARCÍA-TEJEIRO, Beatriz AGUIRRE GERVÁS, María D. CALVO NIEVES, Rosa BUSTAMANTE, Maria D. GANFORNINA, and Diego SANCHEZ

\section{Research Highlights}

First evaluation of paradoxical ApoD decrease in cancer tissues in oxidative stress.

Lipid peroxides increase and ApoD decrease during tumor progression, prominently in CRC stage I.

In CRC ApoD expression is heterogeneous: low in stroma, high in dysplastic epithelium.

ApoD promoter is basally methylated in HT-29 cells, but is able to respond to oxidative stress.

ApoD does not modify proliferation or apoptosis in control conditions, but promotes apoptosis upon oxidative stress. 


\section{Expression and potential role of Apolipoprotein D on the death-survival balance of human colorectal cancer cells under oxidative stress conditions}

Raquel BAJO-GRAÑERAS ${ }^{1}$, Jesús CRESPO SANJUAN ${ }^{2}$, Rosa M. GARCÍA CENTENO $^{2}$, José Antonio GARROTE-ADRADOS ${ }^{2}$, Gabriel GUTIERREZ ${ }^{3}$, Manuel GARCÍA-TEJEIRO ${ }^{2}$, Beatriz AGUIRRE GERVÁS ${ }^{2}$, María D. CALVO NIEVES ${ }^{2}$, Rosa BUSTAMANTE ${ }^{2}$, Maria D. GANFORNINA ${ }^{1 *}$, and Diego SANCHEZ ${ }^{* \S}$

1. Instituto de Biología y Genética Molecular-Departamento de Bioquímica y Biología Molecular y Fisiología, Universidad de Valladolid-CSIC, Valladolid, Spain.

2. Hospital Clínico Universitario de Valladolid, Valladolid, Spain.

3. Departamento de Genética, Universidad de Sevilla, Sevilla, Spain

* MDG and DS contributed equally to this work.

Running title: ApoD in human colorectal cancer

Abstract word count: 244; Main text word count: 4965; Bibliography: 50 references Number of figures: 6; Number of tables: 2; Number of Supplementary figures: 1; Number of Supplementary tables: 3

$\S$ Author for correspondence:

Diego Sánchez

Instituto de Biología y Genética Molecular, c/ Sanz y Forés 3,

Universidad de Valladolid-CSIC,

47003 Valladolid, Spain.

Phone: 983-184814

Fax: 983-184800

e-mail: lazarill@ibgm.uva.es

\section{Grant support}

This work has been supported by grants to M.D.G. and D.S. (MEC grant BFU200500522; JCyL grant VA049A05; and MICINN grant BFU2008-01170), and to R.B. (GRS/278/A/08).

\section{Disclosure of Potential Conflicts of Interest}

Authors declare no conflict of interest exists in relation to the content of this manuscript. Neither the author's institutions nor the funding agencies had a role in the study design, data collection and analysis, decision to publish, or preparation of the manuscript. 


\begin{abstract}
Inverse correlations of Apolipoprotein D (ApoD) expression with tumor growth have been shown, therefore proposing ApoD as a good prognostic marker for diverse cancer types, including colorectal cancer (CRC). Besides, ApoD expression is boosted upon oxidative stress (OS) in many pathological situations. This study aims at understanding the role of ApoD in the progression of human CRC. Samples of CRC and distant normal tissue $(n=51)$ were assayed for levels of lipid peroxidation, expression profile of OS-dependent genes, and protein expression. Three single-nucleotide-polymorphisms in the ApoD gene were analyzed ( $n=139)$, with no significant associations found. Finally, we assayed the effect of ApoD in proliferation and apoptosis in the CRC HT-29 cell line. In CRC, lipid peroxides increase while ApoD mRNA and protein decrease through tumor progression, with a prominent decrease in stage I. In normal mucosa ApoD protein is present in lamina propia and enteroendocrine cells. In CRC ApoD expression is heterogeneous, with low expression in stromal cells and high expression in the dysplastic epithelium. ApoD promoter is basally methylated in HT-29 cells, but it retains the ability to respond to OS. Exogenous addition of ApoD to HT-29 cells does not modify proliferation or apoptosis levels in control conditions, but it promotes apoptosis upon paraquat-induced OS. Our results show ApoD as a gene responding to OS in the tumor microenvironment. Besides using ApoD as marker of initial stages of tumor progression, it can become a therapeutic tool promoting death of proliferating tumor cells suffering OS.
\end{abstract}

Keywords: lipocalin, oxidative stress, proliferation, apoptosis, lipid peroxidation 


\section{Introduction}

Colorectal cancer (CRC) is the second most common cancer in developed countries, being the third in frequency worldwide. CRC counts as the second most frequent cancer in women, following breast cancer, while is the third most common cancer in men, after those from prostate and lung.

In terms of causes underlying $\mathrm{CRC}$, well known risk factors are hereditary genetic predisposition, age, inflammatory colon diseases, and diet composition (Benson, 2007). A correlation between inflammation and CRC development has been observed in both chronic inflammation processes and inflammatory bowel disease. The link between them may be the increase in COX-2 and NFkB during inflammation, which triggers the release of TNFa and IL-6. These signals have been associated with tumor growth (Kraus and Arber, 2009).

Growing evidence also points to the participation of reactive oxygen species (ROS) and their reactive derivatives in the pathogenic origin and development of CRC. Inflammation and environmental factors lead to the generation of large amounts of ROS in colon tissue, inducing in turn oxidative stress (OS). ROS damages DNA, proteins and lipids, and these factors are correlated with tumor growth (Itzkowitz and Yio, 2004;

Ohshima et al., 2003; Olinski et al., 1998). CRC cells show an increase in lipid peroxidation byproducts that could be triggered by the increased arachidonic acid (AA) levels attained by the increased activity of COX-2 (Bartsch and Nair, 2002; Schmid et al., 2000). The accumulation of lipid peroxidation results in cell damage and death. However, cancer cells tend to reduce the levels of the anti-proliferative cytokine TGF$\beta 1$ and the lipid peroxidation adduct 4-HNE as a way to prevent apoptosis (Zanetti et al., 2003). The levels of lipid peroxidation thus reflect the health state of the tissue. 
Apolipoprotein $\mathrm{D}(\mathrm{ApoD})$ is a member of the Lipocalin protein family whose expression has been related to cell cycle and cancer progression, because this gene is induced by growth arrest and its presence reduces cell proliferation in some cellular models (Do Carmo et al., 2007; Sarjeant et al., 2003). ApoD expression is regulated by p73 and p63, members of the p53 tumor suppressor family, both implicated in development control (Sasaki et al., 2009). Many reports show an inverse correlation of ApoD expression levels with tumor growth (Van Dijk et al., 2006), therefore proposing ApoD as a good diagnostic and prognostic marker.

Our laboratory studies the role of ApoD and its homologues in the nervous system by using genetic model organisms such as the mouse and the fruit fly Drosophila melanogaster. Inducing OS by treatment with the ROS generator paraquat (PQ), we have demonstrated a protective function of ApoD in the organism survival. This effect was associated with a role in regulating tissue homeostasis and in maintaining low levels of lipid peroxidation (Ganfornina et al., 2008; Hull-Thompson et al., 2009; Sanchez et al., 2006). We have recently shown that ApoD contributes to reduce inflammation levels in ROS-injured tissues, and promotes the clearance of lipid peroxidation levels in cells (Bajo-Graneras et al., 2011a; Bajo-Graneras et al., 2011b).

The fact that ApoD expression is inversely correlated with the malignity of various tumors has been described, but what triggers this repression and how it is causally linked to the final outcome of the patient is still poorly understood. As mentioned above, in many instances tumoral tissues develop OS. This fact represents a paradox, since $\mathrm{OS}$ is a positive stimulus triggering ApoD up-regulation in other systems. An analysis of gene expression and an evaluation of oxidative stress in the tissue along the progression of CRC are here combined with studies in a cell-culture system to solve this 
question. Our aim is to get a deeper understanding of how ApoD has an impact in cancer progression and patient survival.

In this report we study the expression of ApoD in different stages of cancer progression, and its relationship with the levels of lipid peroxidation in CRC tissues. We also evaluate OS-dependent genes that show co-regulated expression patterns with ApoD, to uncover potential signaling pathways that can become targets for therapeutic intervention. Our results show a repression of ApoD gene expression in CRC, particularly in the initial stages of the disease, which correlates with an elevation of lipid peroxides adducts in the tissue. We also found several genes involved in ROS metabolism and antioxidant function that show expression patterns similar to ApoD through CRC progression stages. Finally, the role of ApoD in proliferation and apoptosis of tumor cells was studied, and the dependence of gene expression on the DNA methylation state will be discussed in the context of tumor development and progression. 


\section{Materials and Methods}

\section{Patients and tumor features}

Our study was conducted on a group of 51 patients, of $79.4 \pm 10.9$ years of age, surgically treated for colorectal cancer at the Surgery Department of the Hospital Clínico Universitario de Valladolid (Spain) (Table 1). The time since CRC diagnosis was 3-8 weeks. The study was approved by the Hospital Ethics Committee, in accordance with The Code of Ethics of the World Medical Association for experiments involving humans, and all subjects provided informed consent for the procedures.

The tumors belong to the histological type adenocarcinoma, and were diagnosed by routine histopathological examination in the Pathology Department of the hospital.

The clinical evaluation of CRC progression involves tumor features such as size, penetration of colon tissue, lymph node and vascular invasion, and the presence of distant metastases. We followed the classification stages (E0-IV), advocated by the American Joint Committee on Cancer (AJCC), to categorize our samples.

Samples of tumor and healthy mucosa were selected, being the latter excised out of tissue at least $6 \mathrm{~cm}$ away of tumor edges. The samples used for biochemical and molecular biology experiments $\left(\sim 1 \mathrm{~cm}^{3}\right)$ were processed within $30-45$ minutes after resection, and either frozen in RNAlater (Ambion), or snap frozen and stored in liquid nitrogen. Samples used for immunohistochemistry were fixed in formalin and embedded in paraffin.

\section{Immunohistochemistry}

The paraffin-embedded samples were sectioned ( $3 \mu \mathrm{m}$-thick) in a rotary microtome (Thermo), and the sections were mounted onto poly-L-lysine coated glass slides. The 
hydration, blocking, washes, and incubation with antibodies were performed in the automated system BOND-MAX (Leica) using bond polymer refine detection. ApoD immunohistochemistry was performed with rabbit anti-ApoD (Santa Cruz, CA), and HRP-conjugated secondary antibodies. After dehydration, clearance and mounting, the sections were observed with an Eclipse 90i (Nikon) microscope equipped with a DSRi1 (Nikon) digital camera. Images were acquired and processed with NIS-Elements BR 3.0 software (Nikon).

Evaluation of histological samples was carried out in 200x fields of randomly selected slides, and assessed by an expert pathologist. ApoD staining was categorized in 4 classes according to the percentage of ApoD-positive cells: $1(0 \%), 2(<15 \%), 3(15-$ $50 \%)$ and $4(>50 \%)$.

\section{Immunoblot analysis}

Tumor and normal mucosal tissues, were homogenized in lysis buffer [1\% Nonidet P40, 0.1\% SDS, $10 \%$ Glycerol, $1 \%$ sodium deoxycholate, 1 mM DTT, 1 mM EDTA, 100 mM HEPES, 100 mM KCl, 10\% Complete Protease Inhibitors (Roche) in PBS], centrifuged after $30 \mathrm{~min}$ at $4{ }^{\circ} \mathrm{C}$, and the supernatants were stored at $-20^{\circ} \mathrm{C}$ until further use.

Protein concentration in the samples was determined with the Micro-BCA ${ }^{\mathrm{TM}}$ protein assay (Pierce). Immunoblot analyses were performed with $30 \mu \mathrm{g}$ of total protein separated by SDS-PAGE on a $12 \%$ polyacrylamide gel and transferred to PVDF membranes following standard procedures. As primary antibodies, we used a rabbit serum anti-human ApoD (generated by Dr. C. López-Otín, Univ. Oviedo, Spain). Each blot was also incubated with HRP-conjugated anti- $\beta$-Actin antibody (Sigma) for normalization purposes. Membranes were developed with ECL (Millipore). The 
integrated optical density of the immunoreactive protein bands was measured in images taken within the linear range of the CCD camera (VersaDoc, BioRad) avoiding signal saturation. Mean \pm SD of arbitrary density units was calculated from at least duplicate blots.

\section{Quantitative real-time RT-PCR}

Tissue samples stored in RNAlater were homogenized in TRIzol (Invitrogen) with an OMNI blender (three $10 \mathrm{~s}$ strokes at maximum speed). RNA from tissues or cells was extracted following the TRIzol protocol. Total RNA $(1 \mu \mathrm{g})$ was reverse-transcribed with Prime-ScriptTM (Takara) and treated with DNaseI. The cDNA obtained was used as template for qRT-PCR amplifications. To quantify human ApoD expression we used SYBR Green I (Takara) and the primers Human ApoD-Forward: 5'-

CCACCCCAGTTAACCTCACA and Human ApoD-Reverse: 5'-

CCACTGTTTCTGGAGGGAGA. The human gene RPL18, amplified with primers RPL18-Forward: 5'-CCATCATGGGAGTGGACAT and RPL18-Reverse: 5'CACGGCC GTCTTGTTTTC, was used as a reference because neither genotype nor treatment gives a significant fold change. Amplifications were performed in 5 (ApoD) or 4 (RPL18) replicates in a Rotor-Gene RG-3000 (Corbett Research) thermal cycler. Cycling conditions were: $95^{\circ} \mathrm{C}, 5 \mathrm{~min} ; 40$ cycles $\left(95^{\circ} \mathrm{C}, 30 \mathrm{~s} ; 55^{\circ} \mathrm{C}, 15 \mathrm{~s}, 72^{\circ} \mathrm{C}, 15 \mathrm{~s}\right)$.

To study the expression of genes related to the antioxidant response and ROS metabolism, we used qRT-PCR and a SybrGreen-based array (PAHS-065; SABiosciences). Gapdh was selected as the reference gene. Amplifications were performed in quadruplicate in an ABI Prism 7900HT. Standard cycling conditions were: $95^{\circ} \mathrm{C}, 5 \mathrm{~min} ; 40 \mathrm{X}\left(95^{\circ} \mathrm{C}, 30 \mathrm{~s} ; 60^{\circ} \mathrm{C}, 1 \mathrm{~min}\right)$. 
Changes in transcriptional expression were estimated using the $\Delta \Delta \mathrm{C}_{\mathrm{T}}$ method (Livak and Schmittgen, 2001). The following criteria were applied to our analysis: (1) Replicates with variation coefficient $>2.5 \%$ were excluded. (2) Undetermined $C_{T}$ values (gene expression below detection levels) were assigned $\mathrm{C}_{\mathrm{T}}=35$. Pairwise comparisons where the gene average $\mathrm{C}_{\mathrm{T}}>35$ cycles in both conditions were excluded from the analysis. (3) Only transcriptional changes $\geq$ twofold were included in the analysis. Significant differences of gene transcriptional changes were evaluated with a Mann-Whitney $U$-test, using $\Delta \mathrm{C}_{\mathrm{T}}$ of each replica. Values are expressed as mean $\pm \mathrm{SEM}$. Only statistically significant $(\mathrm{P}<0.05)$ differences of expression are presented and discussed in the text.

\section{ApoD Polymorphism analysis}

Blood samples of CRC patients included in the study $(n=139)$ were collected before surgery, and those of control healthy subjects $(n=102)$ were obtained upon their approval to enter the study.

Genomic DNA was extracted from peripheral blood cells using a DNA purification system (Magna Pure, Roche, Germany). Three APOD single nucleotide polymorphisms (SNPs) located in chromosome 3 were genotyped. These SNPs were: 1) (rs5952) 15T $\rightarrow$ C, NM_001647.2:c.44T >C, NP_001638.1:p.Phe15Ser. 2) (rs1568565) 352G $\rightarrow$ A, NM_001647.2:c.124-352T >A. 3) (rs 1467282) $+718 \mathrm{C} \rightarrow \mathrm{T}$, NM_001647.2:c.334+718T>C. Genotyping was carried out in a LightCycler 480 II (Roche) by analyzing melting curves of amplicons. Primers and fluorescent probes were designed with the LightCycler ProbeDesign program (v.2.0) and synthesized (Biomol, UK). The PCR reactions were performed with 50-100 ng genomic DNA, $0.5 \mu \mathrm{M}$ of each primer and $0.1 \mu \mathrm{M}$ of each probe. PCR conditions were $95^{\circ} \mathrm{C}, 2$ min followed by 
40 cycles $\left(95^{\circ} \mathrm{C}, 5 \mathrm{~s} ; X^{\circ} \mathrm{C}, 15 \mathrm{~s} ; 72^{\circ} \mathrm{C}, 20 \mathrm{~s}\right)$. Annealing temperature $(X)$ was $62^{\circ} \mathrm{C}$ for rs $5952,60^{\circ} \mathrm{C}$ for $\mathrm{rs} 1467282$, and a touchdown from 57 to $62^{\circ} \mathrm{C}$ for rs 1568565 . Thermal conditions for the analysis of melting curves were $95^{\circ} \mathrm{C}, 30 \mathrm{~s}$ followed by a gradient of $50-90^{\circ} \mathrm{C}$ at a rate of $0.1^{\circ} \mathrm{C} / \mathrm{s}$.

\section{TBARS assay}

Tumor and normal colonic tissues were homogenized in PBS in the presence of butylated hydroxytoluene (BHT). Extracts were incubated with $0.2 \mathrm{M}$ glycine-HCl, pH 3.6 and TBA reagent $(0.5 \%$ TBA, $0.5 \%$ SDS $)$. After $15 \mathrm{~min}$ incubation at $90^{\circ} \mathrm{C}$, samples were cooled on ice and transferred to a 96 well microplate for triplicate readings. Absorbance was monitored at $532 \mathrm{~nm}$ in a Versamax microplate reader (Molecular Devices). The experimental values were normalized to protein concentration. Two independent experiments with measurements in triplicate were performed.

\section{Cell culture and immunocytofluorescence}

The cell line HT-29 was cultured and maintained in DMEM with 10\% FBS, 1\% L-Gln and $1 \% \mathrm{P} / \mathrm{S} / \mathrm{A}$ at $37^{\circ} \mathrm{C}$ in $5 \% \mathrm{CO}_{2}$ with $90-95 \%$ humidity.

To analyze the effect of 2'-deoxy-5-azacytidine (DAC), this demethylating agent was added at $1 \mu \mathrm{M}$ to the culture medium and the cells were cultured for 24 hours, as suggested by Hagemann et al. (Hagemann et al.).

Paraquat (1,1'-dimethyl-4,4'-bipyridinium; Sigma) was added to the culture medium in the absence of FBS for either 6 hours (to assess ApoD expression profile) or for 24 hours (to evaluate cell death and proliferation). 
Human ApoD purified from cystic fluid was added (4 $\mathrm{nM})$ to the cell culture medium for 24 hours in the absence of FBS.

Cells used for proliferation and apoptosis assays, as well as for ApoD immunofluorescence, were cultured onto poly-L-lysine coated coverslips. Fixation was performed in $4 \%$ formaldehyde in PBS for 15 min, followed by washes in PBS, and cells were blocked and permeabilized in PBS with $0.25 \%$ Triton X-100 and $1 \%$ normal goat serum. A rabbit primary antibody anti-human ApoD (generated by C. López-Otín, Univ. de Oviedo) and an Alexa 488-conjugated secondary antibody were used for ApoD immunofluorescence. After mounting with Vectashield-DAPI (Vector Labs), the cells were observed with an Eclipse 90i (Nikon) microscope, and images were taken with a DS-Ri1 (Nikon) digital camera, acquired with NIS-Elements BR 3.0 software (Nikon) and processed with ImageJ (v1.45s). For normal, proliferating or apoptotic cell counting, we acquired images under the same conditions of illumination, diaphragm and condenser adjustments, exposure time, background correction and color levels. A minimum of five 20x fields randomly taken were used for quantification.

\section{Proliferation and apoptosis assays}

A TUNEL labeling kit (Roche) was used to evaluate apoptotic cell death. Cell proliferation was assessed with the Clik-i ${ }^{\circledR}$ EdU kit (Invitrogen) according to the manufacturer's protocol.

\section{Statistical analysis}

Statistical analyses used for testing differences in expression levels were performed with Statgraphics plus (v 5.0) and Sigmaplot (11.0) softwares. $p<0.05$ was defined as a 
threshold for significant changes. SNPs association analysis was performed with SNPStats (Sole et al., 2006; http://bioinfo.iconcologia.net/snpstats/start.htm). 


\section{Results and Discussion}

\section{Lipid peroxidation increases with the clinical stage of colorectal cancer.}

The levels of lipid peroxidation adducts were evaluated with the TBARS method in our samples of adenocarcinoma and control adjacent tissue. Overall, the lipid peroxidation levels are increased in cancer tissues compared to normal mucosa (Fig. 1A), as was previously described in blood (Farias et al., 2011). However, when different stages of cancer development are taken into account, a maximum increase in TBARS signal was observed in stage IV adenocarcinomas (Fig. 1B).

The particular metabolic demands of cancer cells is known to generate increased levels of reactive oxygen species (ROS) in many tumor types, and this in turn results in peroxidation of cell membrane phospholipids. An increase in lipid peroxidation, both in blood and cancerous tissue samples, has been previously reported in primary CRC patients (Hendrickse et al., 1994; Ozdemirler et al., 1998; Skrzydlewska et al., 2005). In particular, Skrzydlewska et al. (2005) found a steady increase in lipid peroxide adduct MDA in malignant tissue of stages II-IV, and a sustained increase of 4-HNE. Although our results confirm the previous findings, we observed a sharp increase in lipid peroxide adducts in stage IV of CRC. Our results are also in agreement with the reported deployment in stage IV CRC of non-enzymatic antioxidants such as GSH and vitamins C and E (Skrzydlewska et al., 2005).

\section{ApoD expression levels in CRC progression.}

An extensive literature supports the notion that tumor cells maintain low levels of ApoD in their surroundings, and a decreased mRNA and/or protein expression has been reported in breast (Diez-Itza et al., 1994), ovary (Vazquez et al., 2000), prostate (Rodriguez et al., 2000), hepatic (Utsunomiya et al., 2005; Vizoso et al., 2007), neural 
(Hunter et al., 2005; Hunter et al., 2002), and esophageal cancer (Yamashita et al., 2002). In primary colorectal cancer, Ogawa et al. (Ogawa et al., 2005) corroborated a similar down-regulation of ApoD mRNA, and, by establishing two categories of mRNA expression, they found a positive correlation between ApoD levels and CRC patient survival. However, an account of the development of ApoD expression in different tumor stages has not been studied. We therefore have examined the expression of ApoD in CRC tissue compared to normal colonic mucosa, and have quantified ApoD gene expression by qRT-PCR and protein levels by immunoblot at different stages.

ApoD mRNA levels show an overall decrease in malignant tissue, with a particularly strong decline in mRNA levels in stage I CRC tissue (Fig. 2A). This sharp downregulation of mRNA in the initial stages of the tumor accounts for the decrease in protein levels observed in immunoblot studies (Fig. 2B). The reduced protein levels are then maintained during subsequent tumor developmental stages, with a lesser amount of down-regulation in stages II and III.

\section{Immunohistochemical localization of ApoD in normal mucosa and CRC tissue.}

ApoD is found to be expressed in cells of normal colonic mucosa both in the epithelium (white arrow in Fig. 3A) and the lamina propia (arrow in Fig. 3A). In the epithelium, ApoD labeling is observed in the cytoplasm of cells located basally. According to their location and morphology (white arrow in Fig. 3B), these ApoD-positive cells could be the endocrine cells of the crypts, known to be secreting a number of hormones as well as cell stress proteins such as Heat shock protein 1 and Superoxide dismutase 1

(Nikoulina et al., 2010). Interestingly, enteroendocrine colonic cells are involved in immune activation and inflammatory response (reviewed by (Khan and Ghia, 2010), a role that has been proposed for ApoD (Bajo-Graneras et al., 2011a; Do Carmo et al., 2008; Ganfornina et al., 2010). In the lamina propia, ApoD is seen as a cytoplasmic 
vesicular labeling in plasma cells (Fig. 3C-D), possibly in fibroblasts, a cell type known to express ApoD (Smith et al., 1980; Spreyer et al., 1990). Other unidentified ApoDexpressing cells are seen in the submucosa (arrow in Fig. 4E).

After studying the localization of cells expressing ApoD in the normal mucosa, we proceeded to find out whether the decrease in ApoD mRNA and protein levels observed in CRC malignant tissues (Fig. 2) is due to a general reduction in expression in the cells that normally express ApoD, or alternatively to a heterogeneous decrease in ApoDexpressing cells (Fig. 4A-E). A general decrease in ApoD labeling is clear in the tumor tissue (Fig. 4A) compared to the normal tissue (Fig. 4E). However, the decrease in stromal labeling seen in malignant tissues when compared to the normal mucosa (white arrows in Fig. 4A\&B vs. E), is accompanied by an increase in the number of cells expressing ApoD in the dysplastic epithelium of the tumor tissue (arrows in Fig. 4C,D). Thus, the general decrease of ApoD protein expression in tumor tissues is mainly due to a down-regulated expression in stromal cells, but the response of the tissue is more complex than a pure down-regulation of ApoD.

Finally, we evaluated semi-quantitatively the expression of ApoD in histological samples of tumor and normal mucosa tissues. The percentage of ApoD-expressing cells was estimated by scoring the staining obtained with immunohistochemistry. ApoD significantly decreases in malignant tissue progressively with CRC developmental stages (Fig. 4F).

Ogawa et al. (2005) reported a predominant expression of ApoD in normal tissue cells surrounding colorectal tumors. Our results above confirm that finding, but we also uncover a heterogeneous distribution of ApoD-expressing cells in CRC, with more mesenchymal cells seen in the normal mucosa and more ApoD-positive cells in the dysplastic epithelium. 


\section{Expression profile of ROS-dependent genes in CRC progression. Co-regulation}

\section{with ApoD.}

The transcriptional levels of a set of 84 genes known to be related to ROS metabolism and antioxidant response were evaluated by qRT-PCR using the GAPDH gene as a ubiquitous control and the levels of gene transcription in normal tissues as the calibrator for relative quantification.

Most of the genes of our array showed an up-regulation in the tumor tissue as compared to normal colonic tissue (Fig. 5A), and 32 genes showed significant changes of expression in the tumor tissues according to the criteria described in the Methods section. The complete list of genes showing significant changes is in Table 2. The general up-regulation of antioxidant gene expression is known in CRC (Janssen et al., 1998; Skrzydlewska et al., 2005), and accounts for the timely cell response to cope with the increasing levels of oxidative stress generated by the abnormal proliferation of cancerous cells. Since we have studied the gene expression profile in different stages (III; III; IV) we were interested in looking at the patterns of gene expression with tumor progression. Most of the genes studied (63\%) showed a peak of expression at stage III (Expression pattern Type 1; Fig. 5B), while 13\% show higher expression at stages I-II (Expression pattern Type 2; Fig. 5C). Some genes, like SGK2, show an up-regulation in all of the CRC stages (Expression pattern Type 3; Fig. 5C), while only 6\% of genes show increased expression with advanced stages of tumor development (Expression pattern Type 4; Fig. 5E).

The expression profile study also allows searching for genes that show co-regulation of expression with ApoD, as possible targets to study ApoD-related gene pathways. The genes showing down-regulation with tumor development account for $7 \%$ of the total studied (Expression pattern Type 5; Fig. 5F), and some of them are functionally linked 
in a gene network (Fig. 1S and Table 1S). Moreover, though not explored in our arrays, the gene PACAP was found strongly down-regulated in CRC tissues (Shi et al., 2011), and it is known to participate in the regulation of ApoD expression (Kosacka et al., 2011). Another interesting finding of our study is the different expression pattern exhibited by ApoE (Expression pattern Type 2; up-regulated) and ApoD (Expression pattern Type 5; down-regulated), two proteins frequently proposed to show coregulation because of their presumed function in lipoprotein metabolism. These opposite expression profiles, already reported in our previous studies on ApoD function in the nervous system (Bajo-Graneras et al., 2011a; Ganfornina et al., 2010), point to different roles for the two lipoproteins.

It is interesting to note that despite a consistent down-regulation has been found in many cancer types for ApoD, this gene does not stand as a CRC biomarker in several metanalyses of expression profiles (Chan et al., 2008; LaPointe et al., 2012). We think that these results are due to the expression changes with tumor progression reported above. Instead, and based on our results, ApoD could be used as a marker for initial stages of tumor invasion beyond the colonic mucosa.

\section{ApoD polymorphisms and CRC risk.}

Several single nucleotide polymorphisms (SNPs) of the human ApoD gene have been reported to associate with disease states such as Alzheimer's (AD) and schizophrenia (Chen et al., 2008; Hansen et al., 2006). We have genotyped three SNPs (RS5952, RS1568565, and RS1467282) that have been associated to AD (Chen et al., 2008; Helisalmi et al., 2004). The single and multiple SNPs analyses are shown in Tables $2 \mathrm{~S}$ $\& 3$ S. A study of the haplotypes generated by the SNPs analyzed in our study found no significant association with CRC risk (Table 3S). 


\section{ApoD expression in the CRC cell line HT-29 and its role in proliferation and cell}

death.

DNA methylation is a mechanism by which tumor cells silence gene expression (Jones and Baylin, 2007), and several reports have shown that ApoD is a hypermethylated cancer-associated gene (Ogawa et al., 2005; van den Boom et al., 2006; Yamashita et al., 2002). ApoD is up-regulated by, and protects against, oxidative stress (Do Carmo et al., 2007; Ganfornina et al., 2008; Sanchez et al., 2006). As reported here and in other works, ApoD expression is maintained at general low levels in tumor tissues, which along with its positive regulation by growth arrest (Provost et al., 1991) supports the proposal made by several authors that ApoD is a tumor suppressor gene (Ogawa et al., 2005). Nevertheless, malignant cells generate high levels of ROS and boost lipid peroxides, which in turn should increase ApoD expression (Bajo-Graneras et al., 2011a) to be of help as a protecting agent. How could we explain this paradox?

We set up to test the effect of ApoD silencing by methylation, and ApoD regulation by stress, on the proliferation and death of the CRC cell line HT-29 (Fig. 6). Moreover, we tested whether the exogenous addition of human ApoD to the cell culture medium affects cell growth. As shown in figure 6, demethylation with 2'-deoxy-5-azacytidine (DAC) does not affect cell proliferation (Fig. 6A) or cell death (Fig. 6B) under our culture conditions, though it liberates ApoD from methylation-induced silencing and increases its expression (1.6 fold mRNA induction; Fig. 6C) to levels known to significantly decrease cell growth (Yamashita et al., 2002). On the other hand, serum starvation stress halts proliferation without significant effects on cell death. But ApoD added to the culture medium, at concentrations known to protect cells from stress (BajoGraneras et al., 2011a), does not have a significant effect in proliferation or apoptosis levels (Fig. 6A,B). In summary, and though long term effects cannot be discarded, a 
role of ApoD on the proliferative state of HT-29 cells is not supported by our data. Instead, these constantly proliferating cells are able to express ApoD while they have not entered cell cycle. This is clear in figure 6D, where only EdU-negative cells (arrows) express ApoD.

As reviewed above, tumor growth increases ROS and inflammation levels. The treatment of HT-29 cells with the ROS generator Paraquat (PQ), that is also known to induce ApoD expression in a number of experimental models (Bajo-Graneras et al., 2011a; Ganfornina et al., 2008; Sanchez et al., 2006), shows a dramatic effect on cell proliferation and cell death (Fig. 6A,B). Interestingly, the simultaneous addition of exogenous ApoD does not affect proliferation (Fig. 6A), but significantly increases apoptotic cell death upon PQ-induced oxidative stress (Fig. 6B). We should take into account that PQ treatment increases per se ApoD expression to levels similar to those attained by treatment with the demethylating agent DAC (Fig. 6C). Our analysis of ApoD transcriptional levels also suggests that there is an upper limit of endogenous expression that can be reached either by demethylation or after exposure to OS, as no further ApoD expression is attained by simultaneous treatment with DAC and PQ (Fig. $6 C)$.

In summary, here we verify that the ApoD promoter is basally methylated in the CRC HT-29 cell line, which silences to some extent the expression of this lipocalin while the cells are undergoing cell division. However, HT-29 cells do indeed express ApoD, and they retain the ability of overexpressing this protein in response to escalating OS. The concentration of ApoD seems to be critical for its protective effect, as has also been reported in PQ-challenged astrocyte primary cultures (Bajo-Graneras et al., 2011a). An excess of ApoD appears to be detrimental for cell survival, a result also 
supported by the fast and transient gene transcription observed in response to OS (BajoGraneras et al., 2011a; Ganfornina et al., 2008).

The situation in the colorectal tissue would in fact be more complex. Stromal cells would silence ApoD expression, perhaps by methylating the ApoD gene, while cancer cells could still express ApoD when they are not dividing. The general decrease in ApoD protein expression in the malignant tissue is accompanied by increased numbers of cells expressing ApoD in the dysplastic epithelium. When tumor growth progresses OS builds up in the tissue, and cells induce ApoD accounting at least in part for the recovery of expression after the initial down-regulation at early stages (Fig. 2). This effect might be a key factor determining the final levels of ApoD in the tissue, which might favor apoptosis of tumor cells and therefore could influence the final patient survival outcome (Ogawa et al., 2005).

Since no loss-of-function mutation in ApoD has been associated to cancer so far, ApoD cannot be classified as a classical tumor suppressor gene. However, our results strongly support that ApoD is one of the genes that respond to the anomalous physiology occurring in the cancer microenvironment. In this context, ApoD could be used as an exogenous tool to promote the death of proliferating tumor cells when they are simultaneously suffering oxidative stress.

\section{Acknowledgements}

We thank Dr. J. Herreros and Dr. B. Velayos of the General Surgery and Gastroenterology Departments of the Hospital Clínico Universitario de Valladolid for their help in patient recruitment. We also thank the nurse team for sample collection. We thank the Lazarillo Lab (M. Ruiz, N. García-Mateo, M. del Caño \& A. PérezCastellanos) for their helpful discussions and positive criticisms. 


\section{References}

Bajo-Graneras, R., Ganfornina, M.D., Martin-Tejedor, E., Sanchez, D., 2011 a. Apolipoprotein D mediates autocrine protection of astrocytes and controls their reactivity level, contributing to the functional maintenance of paraquat-challenged dopaminergic systems. Glia 59, 1551-1566.

Bajo-Graneras, R., Sanchez, D., Gutierrez, G., Gonzalez, C., Do Carmo, S., Rassart, E., Ganfornina, M.D., 2011b. Apolipoprotein D alters the early transcriptional response to oxidative stress in the adult cerebellum. J Neurochem 117, 949-960.

Bartsch, H., Nair, J., 2002. Potential role of lipid peroxidation derived DNA damage in human colon carcinogenesis: studies on exocyclic base adducts as stable oxidative stress markers. Cancer Detect Prev 26, 308-312.

Benson, A.B., 3rd, 2007. New approaches to assessing and treating early-stage colon and rectal cancers: cooperative group strategies for assessing optimal approaches in early-stage disease. Clin Cancer Res 13, 6913s-6920s.

Chan, S.K., Griffith, O.L., Tai, I.T., Jones, S.J., 2008. Meta-analysis of colorectal cancer gene expression profiling studies identifies consistently reported candidate biomarkers. Cancer Epidemiol Biomarkers Prev 17, 543-552.

Chen, Y., Jia, L., Wei, C., Wang, F., Lv, H., Jia, J., 2008. Association between polymorphisms in the apolipoprotein $\mathrm{D}$ gene and sporadic Alzheimer's disease. Brain Res 1233, 196-202.

Diez-Itza, I., Vizoso, F., Merino, A.M., Sanchez, L.M., Tolivia, J., Fernandez, J., Ruibal, A., Lopez-Otin, C., 1994. Expression and prognostic significance of apolipoprotein D in breast cancer. Am J Pathol 144, 310-320.

Do Carmo, S., Jacomy, H., Talbot, P.J., Rassart, E., 2008. Neuroprotective effect of apolipoprotein D against human coronavirus OC43-induced encephalitis in mice. J Neurosci 28, 10330-10338.

Do Carmo, S., Levros, L.C., Jr., Rassart, E., 2007. Modulation of apolipoprotein D expression and translocation under specific stress conditions. Biochim Biophys Acta 1773, 954-969.

Farias, I.L., Farias, J.G., Rossato, L., Araujo, M.C., Chiesa, J., Morsh, V., Schetinger, M.R., 2011. Correlation between TBARS levels and glycolytic enzymes: the importance to the initial evaluation of clinical outcome of colorectal cancer patients. Biomed Pharmacother 65, 395-400.

Ganfornina, M.D., Do Carmo, S., Lora, J.M., Torres-Schumann, S., Vogel, M., Allhorn, M., González, C., Bastiani, M.J., Rassart, E., Sanchez, D., 2008. Apolipoprotein D is involved in the mechanisms regulating protection from oxidative stress. Aging Cell 7, 506-515.

Ganfornina, M.D., Do Carmo, S., Martinez, E., Tolivia, J., Navarro, A., Rassart, E., Sanchez, D., 2010. ApoD, a glia-derived apolipoprotein, is required for peripheral nerve functional integrity and a timely response to injury. Glia 58, 1320-1334.

Hagemann, S., Heil, O., Lyko, F., Brueckner, B., Azacytidine and decitabine induce gene-specific and non-random DNA demethylation in human cancer cell lines. PLoS One 6, e17388.

Hansen, T., Hemmingsen, R.P., Wang, A.G., Olsen, L., Timm, S., Soeby, K., Jakobsen, K.D., Fenger, M., Parnas, J., Rasmussen, H.B., Werge, T., 2006. Apolipoprotein D is associated with long-term outcome in patients with schizophrenia. Pharmacogenomics $\mathbf{J}$ $6,120-125$. 
Helisalmi, S., Hiltunen, M., Vepsalainen, S., Iivonen, S., Corder, E.H., Lehtovirta, M., Mannermaa, A., Koivisto, A.M., Soininen, H., 2004. Genetic variation in apolipoprotein D and Alzheimer's disease. J Neurol 251, 951-957.

Hendrickse, C.W., Kelly, R.W., Radley, S., Donovan, I.A., Keighley, M.R., Neoptolemos, J.P., 1994. Lipid peroxidation and prostaglandins in colorectal cancer. $\mathrm{Br}$ J Surg 81, 1219-1223.

Hull-Thompson, J., Muffat, J., Sanchez, D., Walker, D.W., Benzer, S., Ganfornina, M.D., Jasper, H., 2009. Control of Metabolic Homeostasis by Stress Signaling Is Mediated by the Lipocalin NLaz. PLoS Genet 5, e1000460.

Hunter, S., Weiss, S., Ou, C.Y., Jaye, D., Young, A., Wilcox, J., Arbiser, J.L., Monson, D., Goldblum, J., Nolen, J.D., Varma, V., 2005. Apolipoprotein D is down-regulated during malignant transformation of neurofibromas. Hum Pathol 36, 987-993.

Hunter, S., Young, A., Olson, J., Brat, D.J., Bowers, G., Wilcox, J.N., Jaye, D., Mendrinos, S., Neish, A., 2002. Differential expression between pilocytic and anaplastic astrocytomas: identification of apolipoprotein D as a marker for low-grade, noninfiltrating primary CNS neoplasms. J Neuropathol Exp Neurol 61, 275-281. Itzkowitz, S.H., Yio, X., 2004. Inflammation and cancer IV. Colorectal cancer in inflammatory bowel disease: the role of inflammation. Am J Physiol Gastrointest Liver Physiol 287, G7-17.

Janssen, A.M., Bosman, C.B., Sier, C.F., Griffioen, G., Kubben, F.J., Lamers, C.B., van Krieken, J.H., van de Velde, C.J., Verspaget, H.W., 1998. Superoxide dismutases in relation to the overall survival of colorectal cancer patients. Br J Cancer 78, 1051-1057. Jones, P.A., Baylin, S.B., 2007. The epigenomics of cancer. Cell 128, 683-692.

Khan, W.I., Ghia, J.E., 2010. Gut hormones: emerging role in immune activation and inflammation. Clin Exp Immunol 161, 19-27.

Kosacka, J., Schroder, T., Bechmann, I., Kloting, N., Nowicki, M., Mittag, A., Gericke, M., Spanel-Borowski, K., Bluher, M., 2011. PACAP up-regulates the expression of apolipoprotein D in 3T3-L1 adipocytes. DRG/3T3-L1 co-cultures study. Neurosci Res 69, 8-16.

Kraus, S., Arber, N., 2009. Inflammation and colorectal cancer. Curr Opin Pharmacol 9, 405-410.

LaPointe, L.C., Pedersen, S.K., Dunne, R., Brown, G.S., Pimlott, L., Gaur, S., McEvoy, A., Thomas, M., Wattchow, D., Molloy, P.L., Young, G.P., 2012. Discovery and validation of molecular biomarkers for colorectal adenomas and cancer with application to blood testing. PLoS One 7, e29059.

Livak, K.J., Schmittgen, T.D., 2001. Analysis of relative gene expression data using real-time quantitative PCR and the 2(-Delta Delta C(T)) Method. Methods 25, 402-408. Nikoulina, S.E., Andon, N.L., McCowen, K.M., Hendricks, M.D., Lowe, C., Taylor, S.W., 2010. A primary colonic crypt model enriched in enteroendocrine cells facilitates a peptidomic survey of regulated hormone secretion. Mol Cell Proteomics 9, 728-741. Ogawa, K., Utsunomiya, T., Mimori, K., Yamashita, K., Okamoto, M., Tanaka, F., Inoue, H., Ikeda, Y., Saku, M., Murayama, S., Mori, M., 2005. Genomic screens for genes upregulated by demethylation in colorectal cancer: possible usefulness for clinical application. Int J Oncol 27, 417-426.

Ohshima, H., Tatemichi, M., Sawa, T., 2003. Chemical basis of inflammation-induced carcinogenesis. Arch Biochem Biophys 417, 3-11.

Olinski, R., Jaruga, P., Zastawny, T.H., 1998. Oxidative DNA base modifications as factors in carcinogenesis. Acta Biochim Pol 45, 561-572. 
Ozdemirler, G., Pabuccuoglu, H., Bulut, T., Bugra, D., Uysal, M., Toker, G., 1998.

Increased lipoperoxide levels and antioxidant system in colorectal cancer. J Cancer Res Clin Oncol 124, 555-559.

Provost, P.R., Marcel, Y.L., Milne, R.W., Weech, P.K., Rassart, E., 1991.

Apolipoprotein D transcription occurs specifically in nonproliferating quiescent and senescent fibroblast cultures. FEBS Lett 290, 139-141.

Rodriguez, J.C., Diaz, M., Gonzalez, L.O., Sanchez, J., Sanchez, M.T., Merino, A.M., Vizoso, F., 2000. Apolipoprotein D expression in benign and malignant prostate tissues. Int J Surg Investig 2, 319-326.

Sanchez, D., Lopez-Arias, B., Torroja, L., Canal, I., Wang, X., Bastiani, M.J.,

Ganfornina, M.D., Walker, D.W., Muffat, J., Rundel, C., Benzer, S., 2006. Loss of glial lazarillo, a homolog of apolipoprotein $\mathrm{D}$, reduces lifespan and stress resistance in Drosophila. Curr Biol 16, 680-686.

Sarjeant, J.M., Lawrie, A., Kinnear, C., Yablonsky, S., Leung, W., Massaeli, H., Prichett, W., Veinot, J.P., Rassart, E., Rabinovitch, M., 2003. Apolipoprotein D inhibits platelet-derived growth factor-BB-induced vascular smooth muscle cell proliferated by preventing translocation of phosphorylated extracellular signal regulated kinase 1/2 to the nucleus. Arterioscler Thromb Vasc Biol 23, 2172-2177.

Sasaki, Y., Negishi, H., Koyama, R., Anbo, N., Ohori, K., Idogawa, M., Mita, H., Toyota, M., Imai, K., Shinomura, Y., Tokino, T., 2009. p53 family members regulate the expression of the apolipoprotein D gene. J Biol Chem 284, 872-883.

Schmid, K., Nair, J., Winde, G., Velic, I., Bartsch, H., 2000. Increased levels of promutagenic etheno-DNA adducts in colonic polyps of FAP patients. Int J Cancer 87, $1-4$.

Shi, H., Hood, K.A., Hayes, M.T., Stubbs, R.S., 2011. Proteomic analysis of advanced colorectal cancer by laser capture microdissection and two-dimensional difference gel electrophoresis. J Proteomics 75, 339-351.

Skrzydlewska, E., Sulkowski, S., Koda, M., Zalewski, B., Kanczuga-Koda, L., Sulkowska, M., 2005. Lipid peroxidation and antioxidant status in colorectal cancer. World J Gastroenterol 11, 403-406.

Smith, L.C., Voyta, J.C., Catapano, A.L., Kinnunen, P.K., Gotto, A.M., Jr., Sparrow, J.T., 1980. Activation of lipoprotein lipase by synthetic fragments of apolipoprotein CII. Ann N Y Acad Sci 348, 213-223.

Sole, X., Guino, E., Valls, J., Iniesta, R., Moreno, V., 2006. SNPStats: a web tool for the analysis of association studies. Bioinformatics 22, 1928-1929.

Spreyer, P., Schaal, H., Kuhn, G., Rothe, T., Unterbeck, A., Olek, K., Muller, H.W., 1990. Regeneration-associated high level expression of apolipoprotein D mRNA in endoneurial fibroblasts of peripheral nerve. EMBO J 9, 2479-2484.

Utsunomiya, T., Ogawa, K., Yoshinaga, K., Ohta, M., Yamashita, K., Mimori, K., Inoue, H., Ezaki, T., Yoshikawa, Y., Mori, M., 2005. Clinicopathologic and prognostic values of apolipoprotein D alterations in hepatocellular carcinoma. Int J Cancer 116, 105-109.

van den Boom, J., Wolter, M., Blaschke, B., Knobbe, C.B., Reifenberger, G., 2006. Identification of novel genes associated with astrocytoma progression using suppression subtractive hybridization and real-time reverse transcription-polymerase chain reaction. Int J Cancer 119, 2330-2338.

Van Dijk, W., Do Carmo, S., Rassart, E., Dalhlback, B., Sodetz, J., 2006. The plasma Lipocalins a1-acid glycoprotein, apolipoprotein D, apolipoprotein $\mathrm{M}$ and complement C8g, in: Akerstrom, B., Borregaard, N., Flower, D., Salier, J. (Eds.), Lipocalins. Landes Bioscience, Georgetown, Texas, pp. 140-166. 
Vazquez, J., Gonzalez, L., Merino, A., Vizoso, F., 2000. Expression and clinical significance of apolipoprotein D in epithelial ovarian carcinomas. Gynecol Oncol 76, 340-347.

Vizoso, F.J., Rodriguez, M., Altadill, A., Gonzalez-Dieguez, M.L., Linares, A., Gonzalez, L.O., Junquera, S., Fresno-Forcelledo, F., Corte, M.D., Rodrigo, L., 2007. Liver expression of steroid hormones and Apolipoprotein D receptors in hepatocellular carcinoma. World J Gastroenterol 13, 3221-3227.

Yamashita, K., Upadhyay, S., Osada, M., Hoque, M.O., Xiao, Y., Mori, M., Sato, F., Meltzer, S.J., Sidransky, D., 2002. Pharmacologic unmasking of epigenetically silenced tumor suppressor genes in esophageal squamous cell carcinoma. Cancer Cell 2, 485495.

Zanetti, D., Poli, G., Vizio, B., Zingaro, B., Chiarpotto, E., Biasi, F., 2003. 4hydroxynonenal and transforming growth factor-betal expression in colon cancer. Mol Aspects Med 24, 273-280. 


\section{Figure and Table Legends}

Figure 1. Lipid peroxidation increases in terminal stages of colorectal cancer. (A) The levels of lipid peroxidation adducts, assayed by TBARS, increase in colorectal tumor tissue of pooled stages compared to control healthy mucosa tissue. (B) When analyzed independently in developmental stages of cancer progression the levels of lipid peroxidation increases mostly in stage IV. Data represent mean \pm SD of samples. Statistical differences were assayed by Anova test. * $p<0.05$.

Figure 2. Human ApoD is down-regulated in CRC tissues. (A) HApoD mRNA expression levels are decreased in colorectal tumor tissue, specially in stage I. Quantitative RT-PCR values are represented with respect to control conditions (calibrator sample). Statistical differences assayed by unpaired Student's t-test in B-E and by Mann-Whitney U-test in F.* $p<0.05$. Relative amounts with respect to control healthy tissue in each tumor stage are shown. (B) HApoD protein levels remain low in tumor tissue during al stages of disease. Detection and quantification of HApoD was performed by immunoblot analysis. The blot shows a representative experiment of pooled samples for each stage of equal amounts of total protein extracts from control and CRC tissues. Bar graph represents mean \pm SD of 3 independent immunoblot experiments. Densitometry values were normalized to $\beta$-actin and shown as percent of control values.

Figure 3. ApoD protein expression in normal colon tissue. Mesenchymal cells express ApoD in normal mucosa (arrows in A,C,D) and a small number of possibly enteroendocrine cells show ApoD labeling in the colonic crypts (white arrows in A,B). 
Figure 4. Human ApoD is globally down-regulated in colorectal tumors but shows heterogeneous changes of expression in different cell types. (A-D) HApoD protein expression in CRC tissues. White arrows point to stromal tissue that shows minimal ApoD labeling. Arrows indicate ApoD-positive cells in the dysplastic epithelium and carcinoma tissue. (E) ApoD expression in normal mucosa shown for comparison. (E) Semiquantitative expression of ApoD by scoring immunohystochemical labeling of samples according to their developmental tumor stage.

Figure 5. Quantitative RT-PCR expression profiles of OS-related genes in CRC tissues of different developmental stages. (A) Cluster analysis and heat map of the genes that showed genotype-dependent significant differences. Columns represent samples, and rows represent genes. Relative quantification scaling and corresponding color codes are shown at the bottom. Fold change values are listed in Table 2. (B-F) Different patterns of gene expression are shown.

Figure 6. Cell proliferation and apoptotic death levels of HT-29 CRC cells in relation to ApoD expression and OS levels. Cell proliferation (A) and apoptotic cell death (B) analyses under different conditions of serum concentration, demethylating treatment (DAC), experimental oxidative stress (PQ) and/or addition of exogenous ApoD. Representative immunofluorescence pictures for each assay are shown on the right. (C) Quantitative RT-PCR expression of ApoD in HT-29 CRC cultures subjected to oxidative stress (PQ), demethylation (DAC) or both treatments, represented with respect to control conditions (calibrator sample). Statistical differences were assayed by MannWhitney U-test; $*$ < 0.05. (D) Immunofluorescent pictures showing endogenous ApoD expression (white arrows) only by cells that have not entered the cell cycle.

Table 1. Clinical data of the CRC cases studied in this work. 
Table 2. Expression profiles of genes related to ROS metabolism and antioxidant response in CRC tumor tissues of different stages using the GAPDH gene as a ubiquitous control and the levels of gene transcription in normal tissues as the calibrator for relative quantification.

\section{Supplementary Figure and Table Legends}

Fig. 1S. Gene pathway analysis of the subsets of oxidative stress responsive genes that show co-regulation with ApoD (down-regulation with tumor progression). Analysis performed with Gene Network Central Pro ${ }^{\mathrm{TM}}$ (http://gncpro.sabiosciences.com). Black circles represent genes whose expression has been measured in our qRT-PCR array. Diamonds represent genes with regulatory or physical interactions with the assayed genes.

Table 1S. Gene information and interactions found by Gene Network Central (http://gncpro.sabiosciences.com/gncpro/gncpro.php) for genes showing the expression pattern type $\mathrm{V}$ in figure 5.

Table 2S and 3S. Single and multiple SNP analyses of control vs. CRC patient ApoD genotypes. 


\section{Figure 1}

A

B
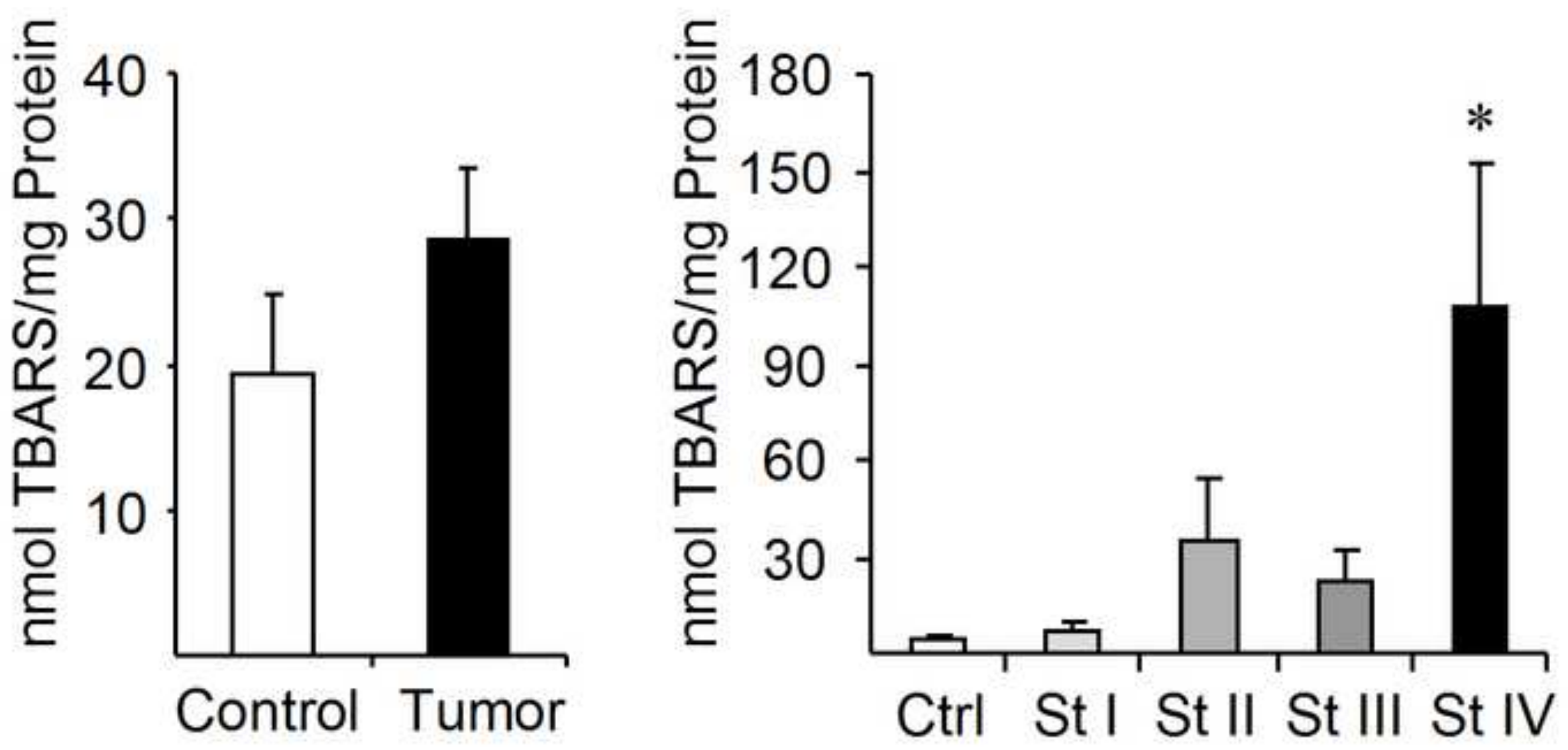
Click here to download high resolution image

\section{Figure 2}

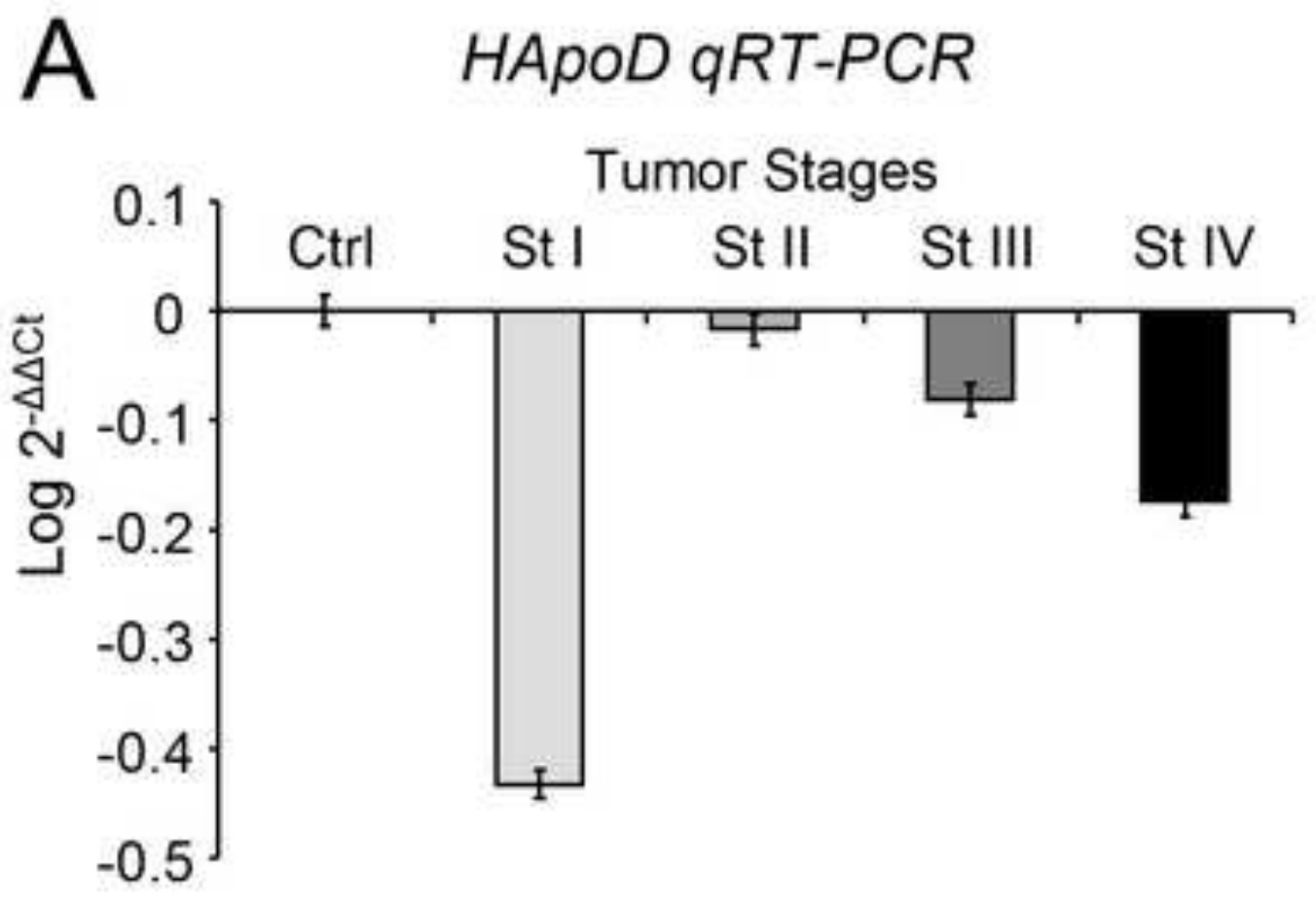

B

HApoD immunoblot

Ctrl St I St II St III St IV
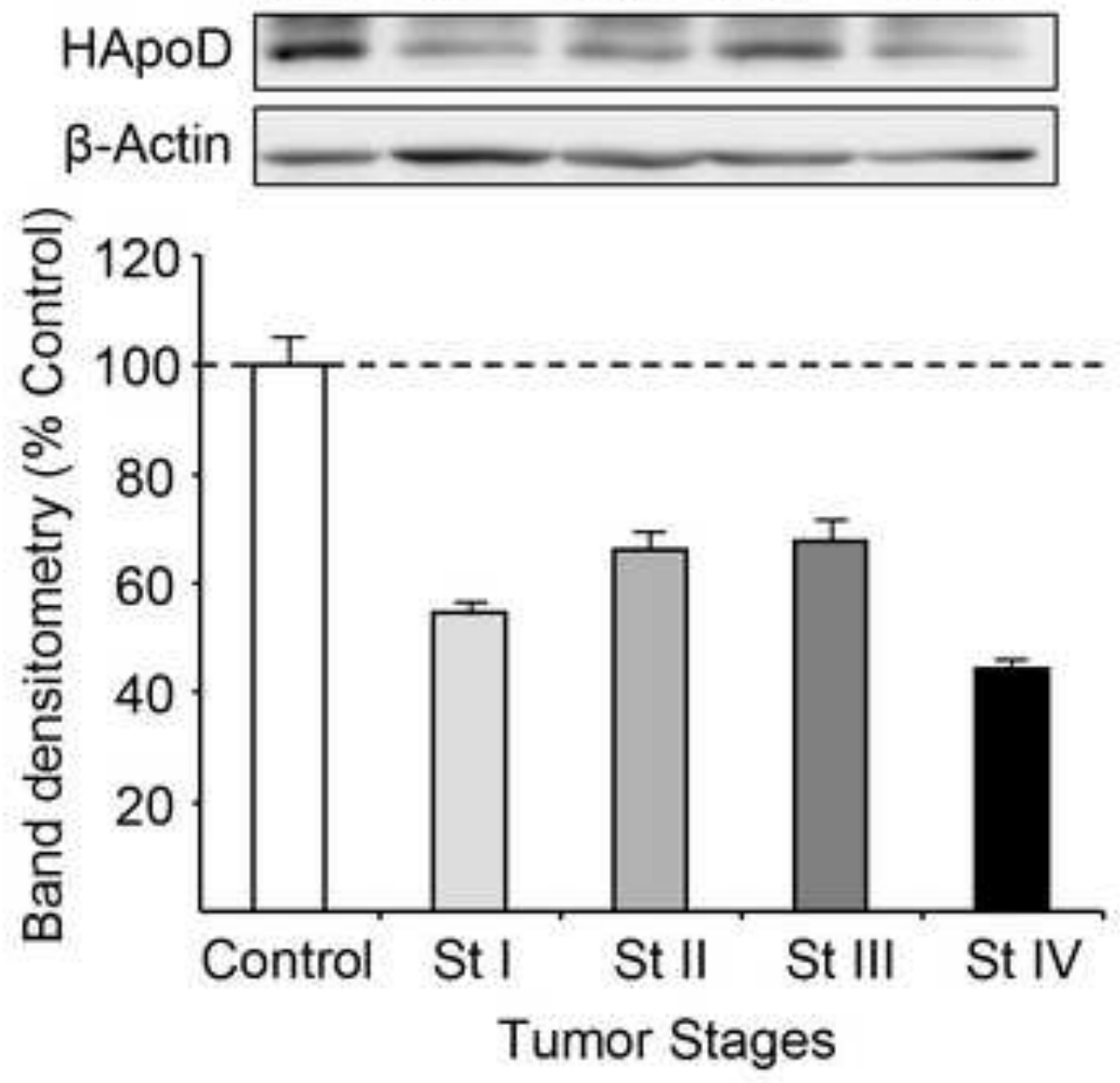
Figure 3
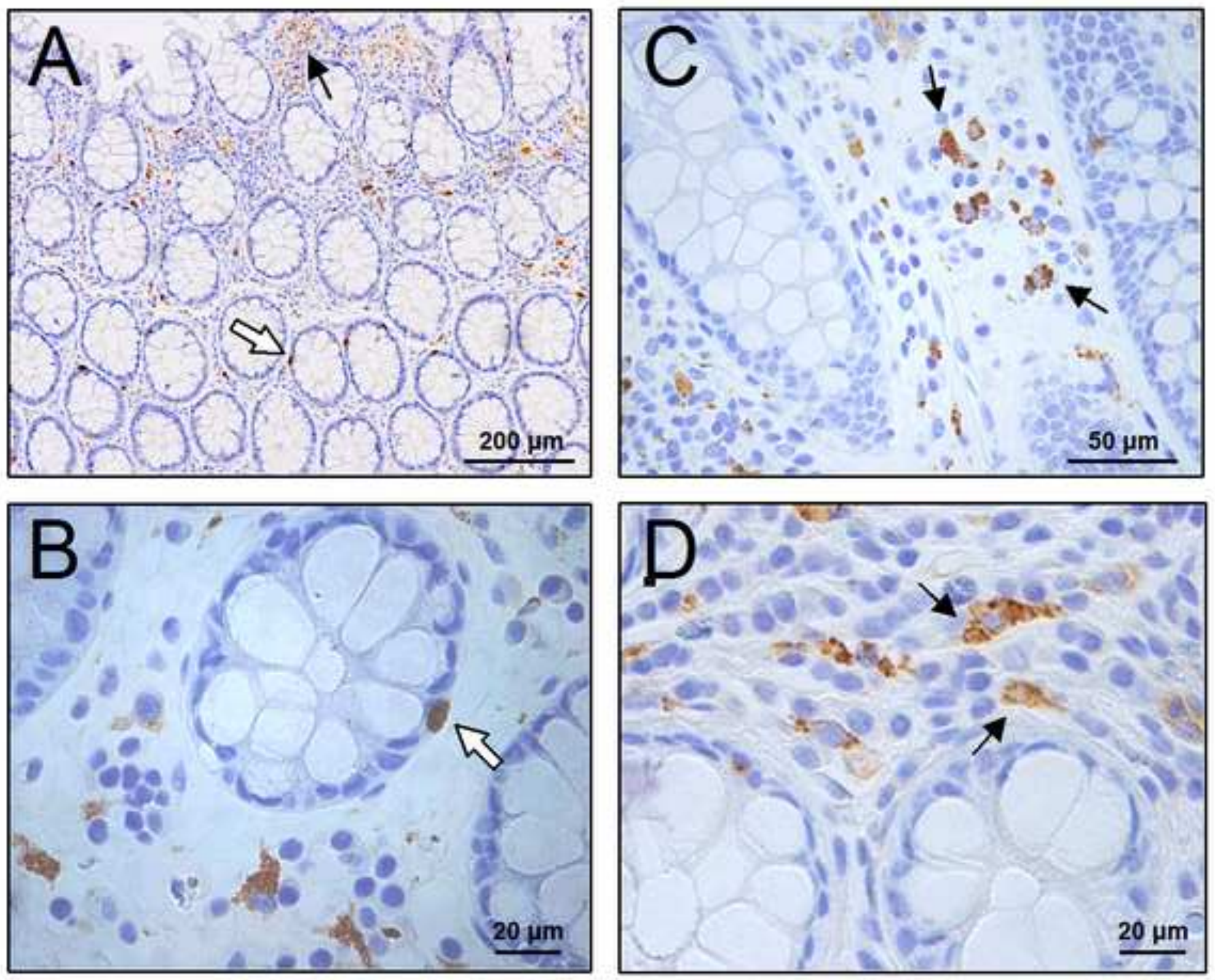


\section{Figure 4}

\section{Cancer tissues}
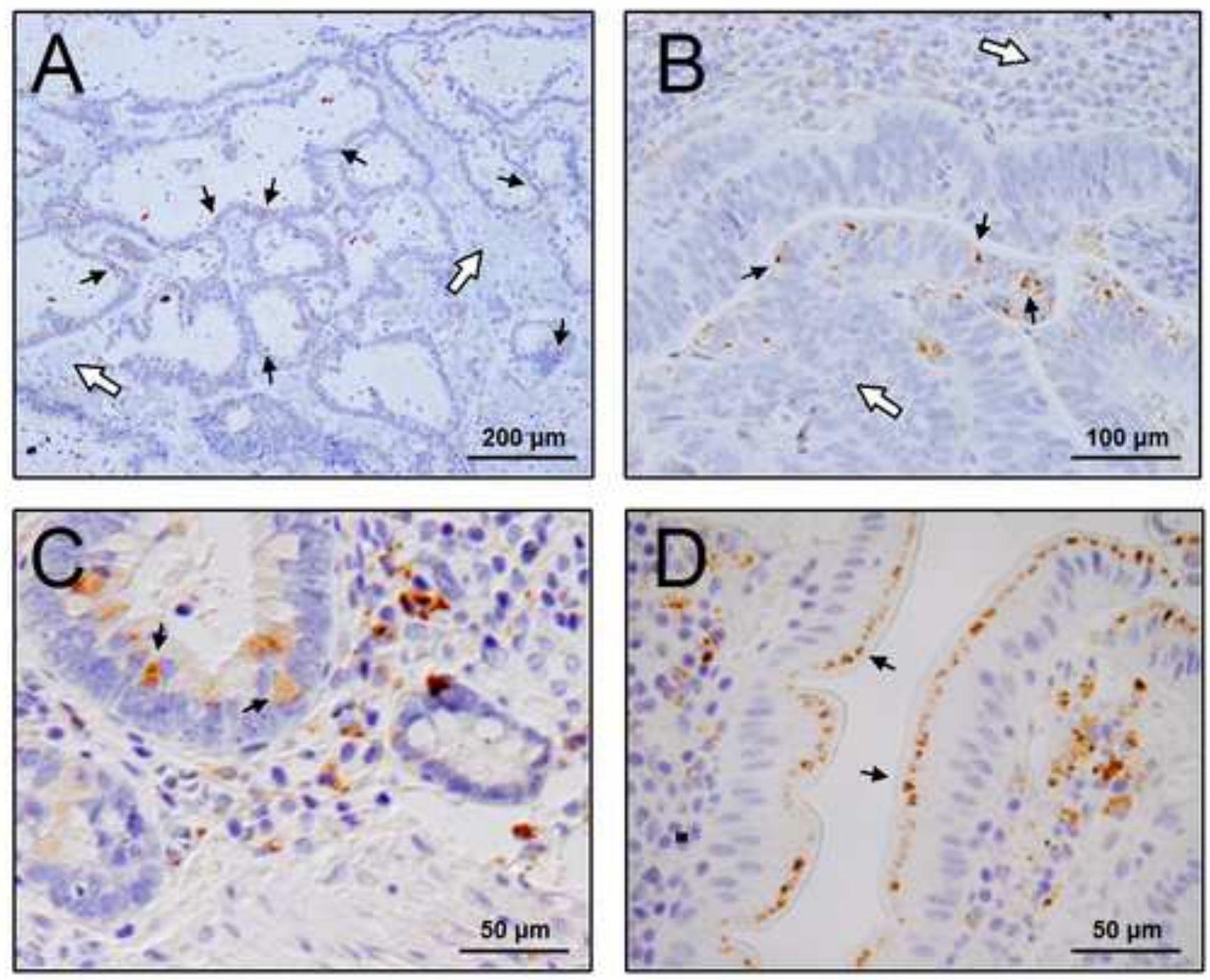

\section{Normal mucosa}

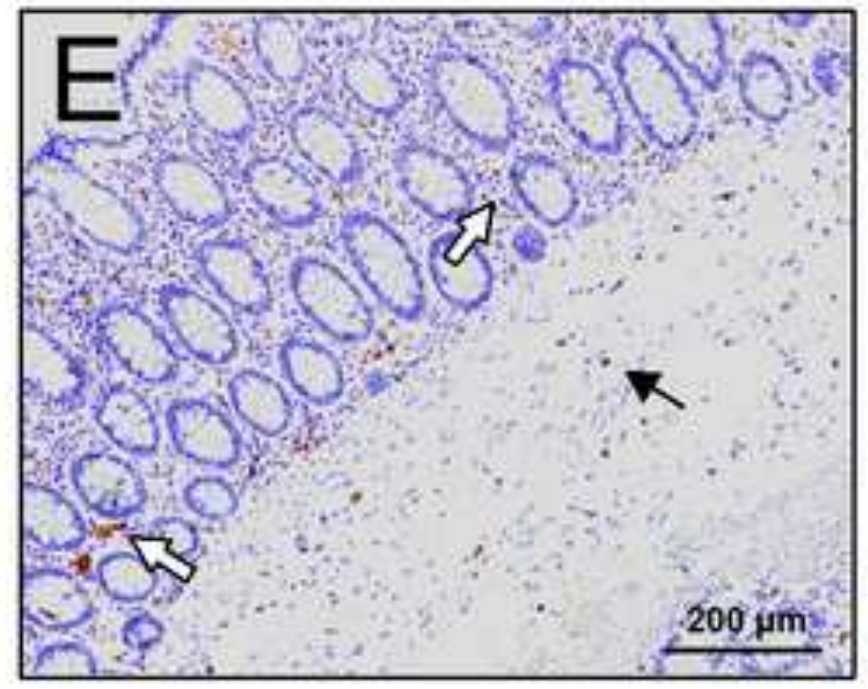

F ApoDIHC Scores

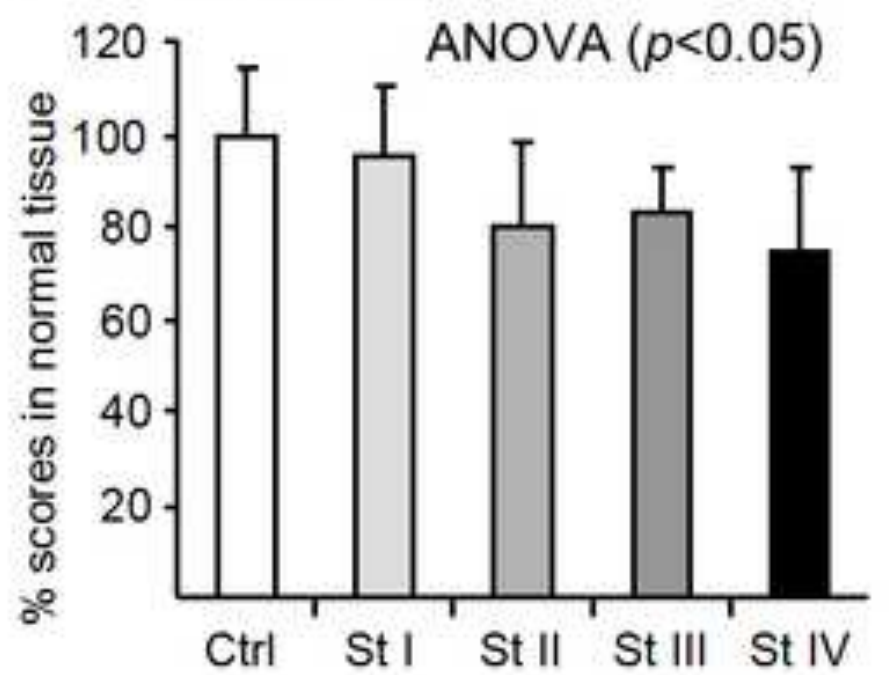




\section{Figure 5}

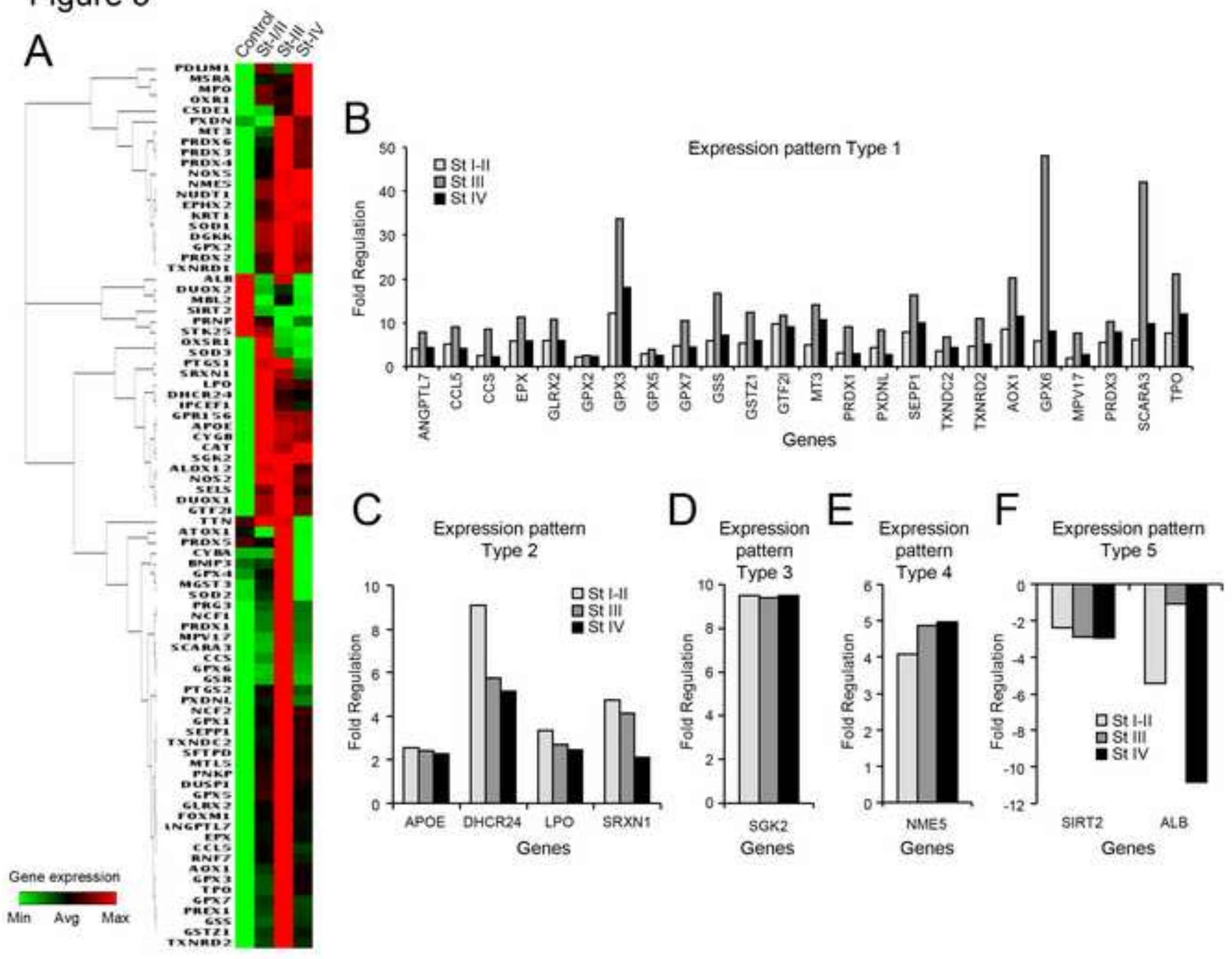


Figure 6
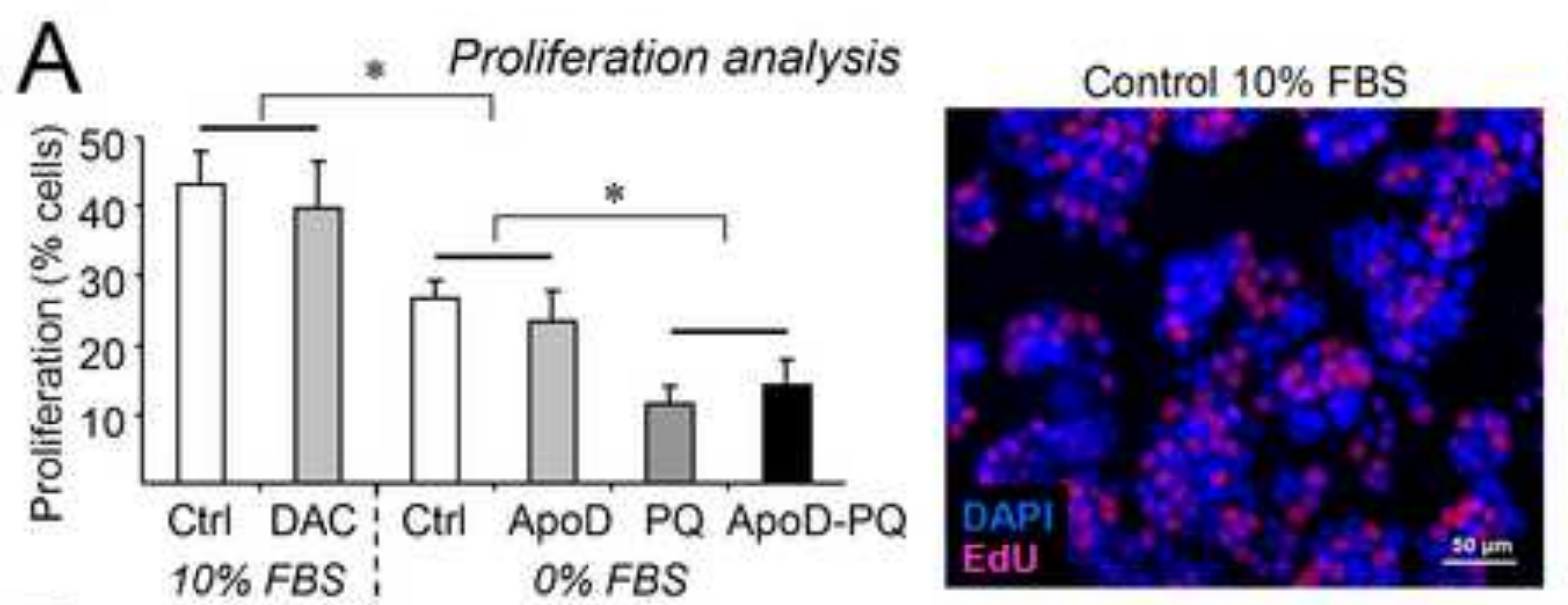

$0 \%$ FBS-4nM ApoD-500 $\mu$ M PQ
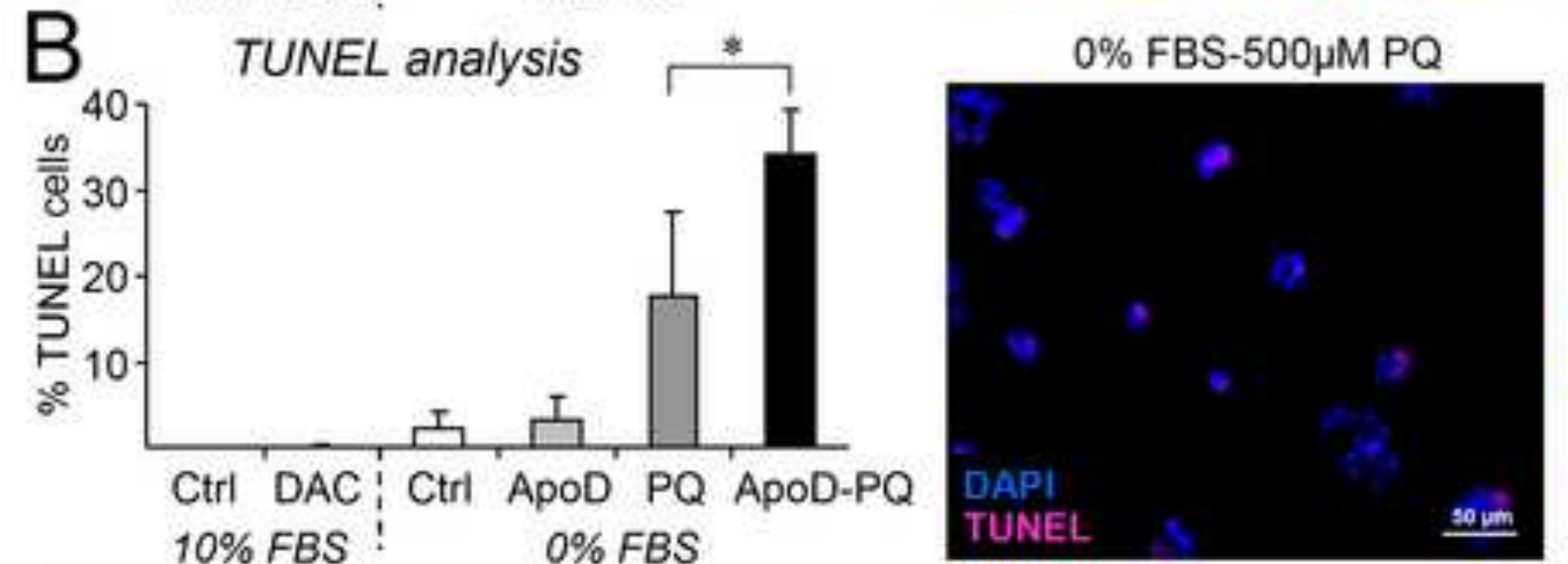

C $0 \%$ FBS

D
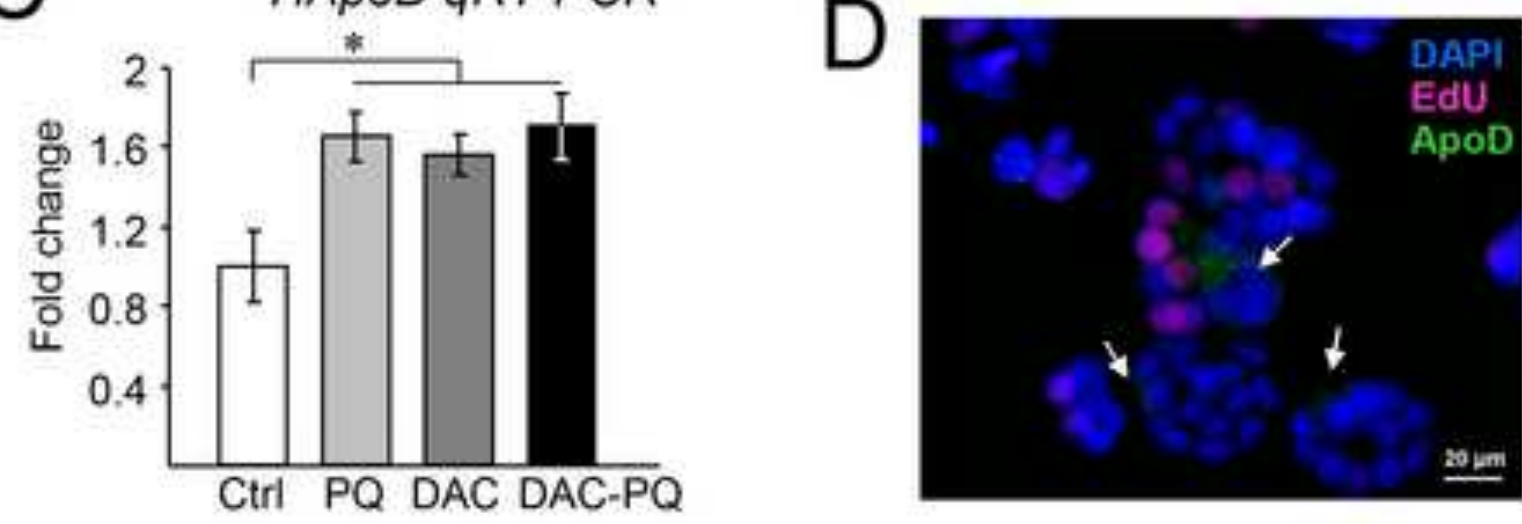

$0 \%$ FBS-4nM ApoD-500 $\mu \mathrm{M} P Q$
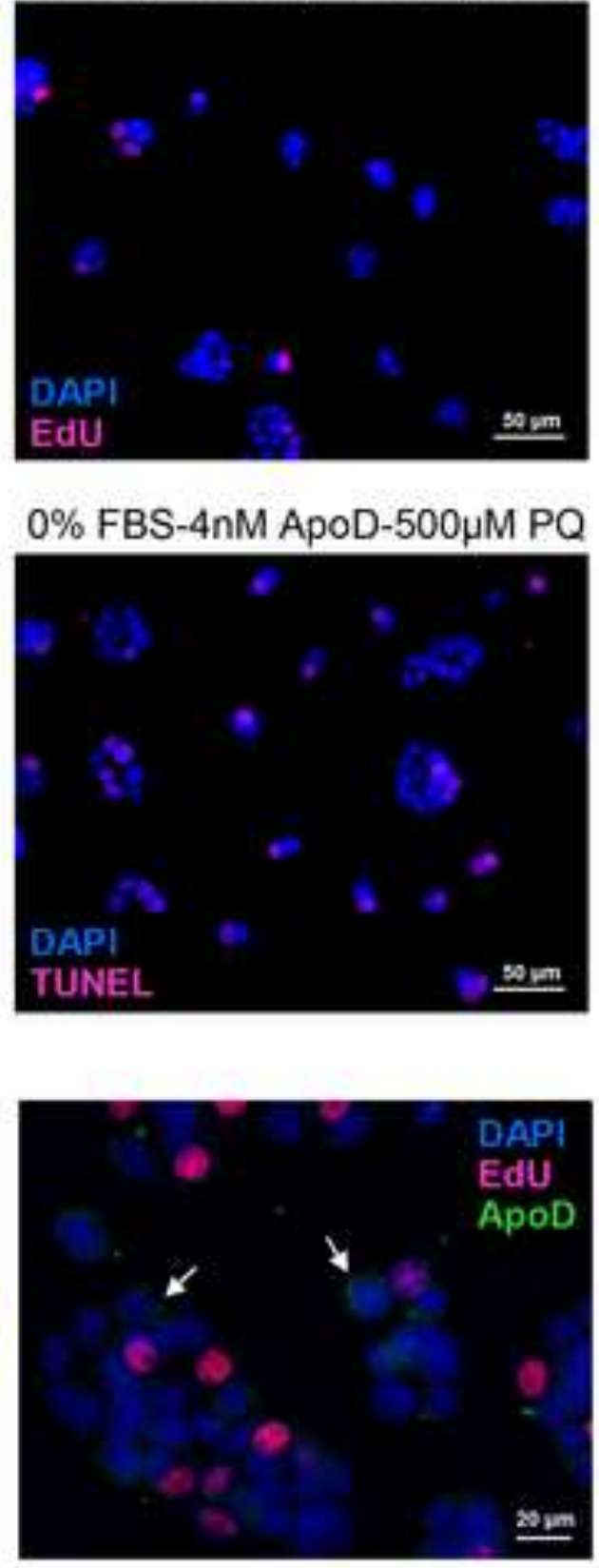
Table 1

\begin{tabular}{|c|c|c|}
\hline \multicolumn{3}{|c|}{ Characteristics of patients studied } \\
\hline Number of patients (n) & & 51 \\
\hline \multicolumn{3}{|l|}{ Gender $(n)$} \\
\hline & Male & $29(56.86 \%)$ \\
\hline & Female & $22(43.14 \%)$ \\
\hline & Gender by stage (male/female) & SI (9/7), SII (8/6), SIII (4/3), SIV (8/6) \\
\hline \multicolumn{3}{|r|}{ 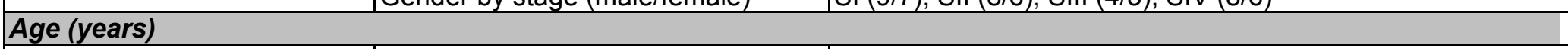 } \\
\hline & Mean age & $70.14 \pm 11.21$ \\
\hline & Age range & $44-91$ \\
\hline & $<50(\mathrm{n})$ & $3(5.88 \%)$ \\
\hline & $>50(n)$ & $48(94.12 \%)$ \\
\hline & $\geq 80(\mathrm{n})$ & $13(25.49 \%)$ \\
\hline & Age by stage & 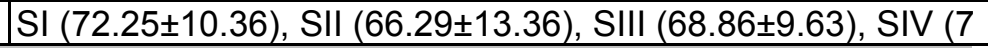 \\
\hline \multicolumn{3}{|l|}{ Tumor size (mm) } \\
\hline & Mean size & $46.90 \pm 25.56$ \\
\hline & Size by stage & 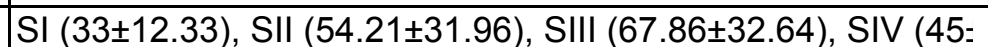 \\
\hline \multicolumn{3}{|l|}{ Depth of invation (n) } \\
\hline & & T1 (3), T2 (14), T3 (24), T4 (7) \\
\hline & Depth of invasion by stage (n) & SI : T1 (3), T2 (13), T3 (0), T4 (0) \\
\hline & & SII : T1 (0), T2 (0), T3 (12), T4 (2) \\
\hline & & SIII : T1 (0), T2 (1), T3 (5), T4 (1) \\
\hline & & SIV : T1 (0), T2 (3), T3 (7), T4 (4) \\
\hline TNM stage (n) (UICC) & & SI (16), SII (14), SIII (7), SIV (14) \\
\hline \multicolumn{3}{|l|}{ Tumor histology $(n)$} \\
\hline & & Nonmucinous (44), Mucinous (7) \\
\hline & Mucinous by stage $(n)$ & SI (2), SII (1), SIII (2), SIV (2) \\
\hline \multicolumn{3}{|c|}{ Grade of differentiation ( $n$ ) } \\
\hline & & G1 (36), G2 (10), G3 (5), G4 (0) \\
\hline & Differentiation by stage & SI: G1 (12), G2 (3), G3 (1) \\
\hline & & SII: G1 (9), G2 (3), G3 (2) \\
\hline & & SIII: G1 (4), G2 (1), G3 (2) \\
\hline & & SIV: G1 (11), G2 (3), G3 (0) \\
\hline \multicolumn{3}{|l|}{ Lymph node status (n) } \\
\hline & & Negative (33), Positive (18) \\
\hline & Positive lymph node by stage $(\mathrm{n})$ & SI (0), SII (0), SIII (6), SIV (12) \\
\hline \multicolumn{3}{|l|}{ Prognosis after 1 year $(n)$} \\
\hline & & Death (6) (11.1\%) \\
\hline & Death by stage $(n)$ & SI (1), SII (1), SIII (3), SIV (1) \\
\hline Control tissues & & $\begin{array}{l}\text { Normal colon adjacent to cancer } n=54 \text { for TBARS analyses, } r \\
\text { anayses and } n=30 \text { for immunoblot analyses }\end{array}$ \\
\hline
\end{tabular}




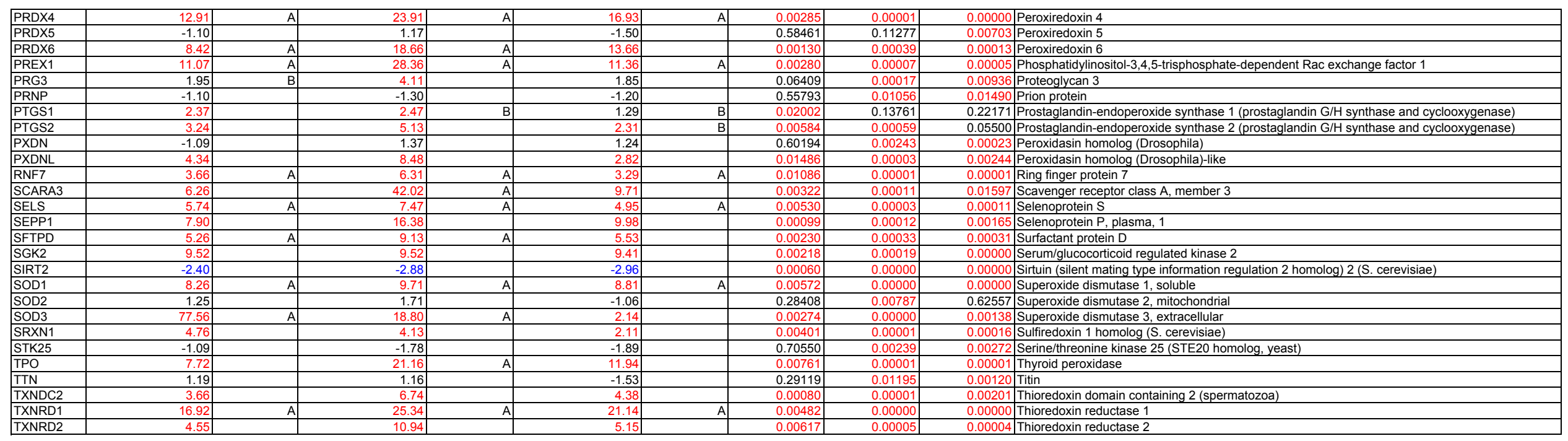

Comments:

A: This gene's average threshold cycle is relatively high $(>30)$ in either the control or the est sample, and is rease to

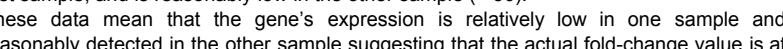
least as large as the calculated and reported fold-change result.

.

B. This gene's average threshold cycle is relatively high ( $>30$ ), meaning that its relative the $p$-value for the fold

\section{Fold Change \& Fold Regulation:} Fold-Change $\left(2^{\wedge}(-\right.$ Delta Delta Ct) $)$ is the normalized gene expression $\left(2^{\wedge}(-\right.$ Delta Ct)) in
the Test Sample divided the normalized gene expression $\left(2^{\wedge}(-\right.$ Delta Ct) $)$ in the Control Fold-Regulation represents fold-change results in a biologically meaningful way. Foldchange values greater than one indicate a positive- or an up-regulation, and the foldregulation is equal to the fold-change.

Fold-change values less than one indicate a negative or down-regulation, and the foldFold

old-change and fold-regulation values greater than 2 are indicated in red; fold-change values less than 0.5 and fold-regulation values less than -2 are indicated in blue.

p-value:

The $p$ values are calculated based on a Student's $t$-test of the replicate $2^{\wedge}(-$ Delta $C t)$ values for each gene in the control group and treatment groups, and $p$ values less than
0.05 are indicated in red. 


\section{Figure 1S}

Gene pathways (GNCPro) analysis

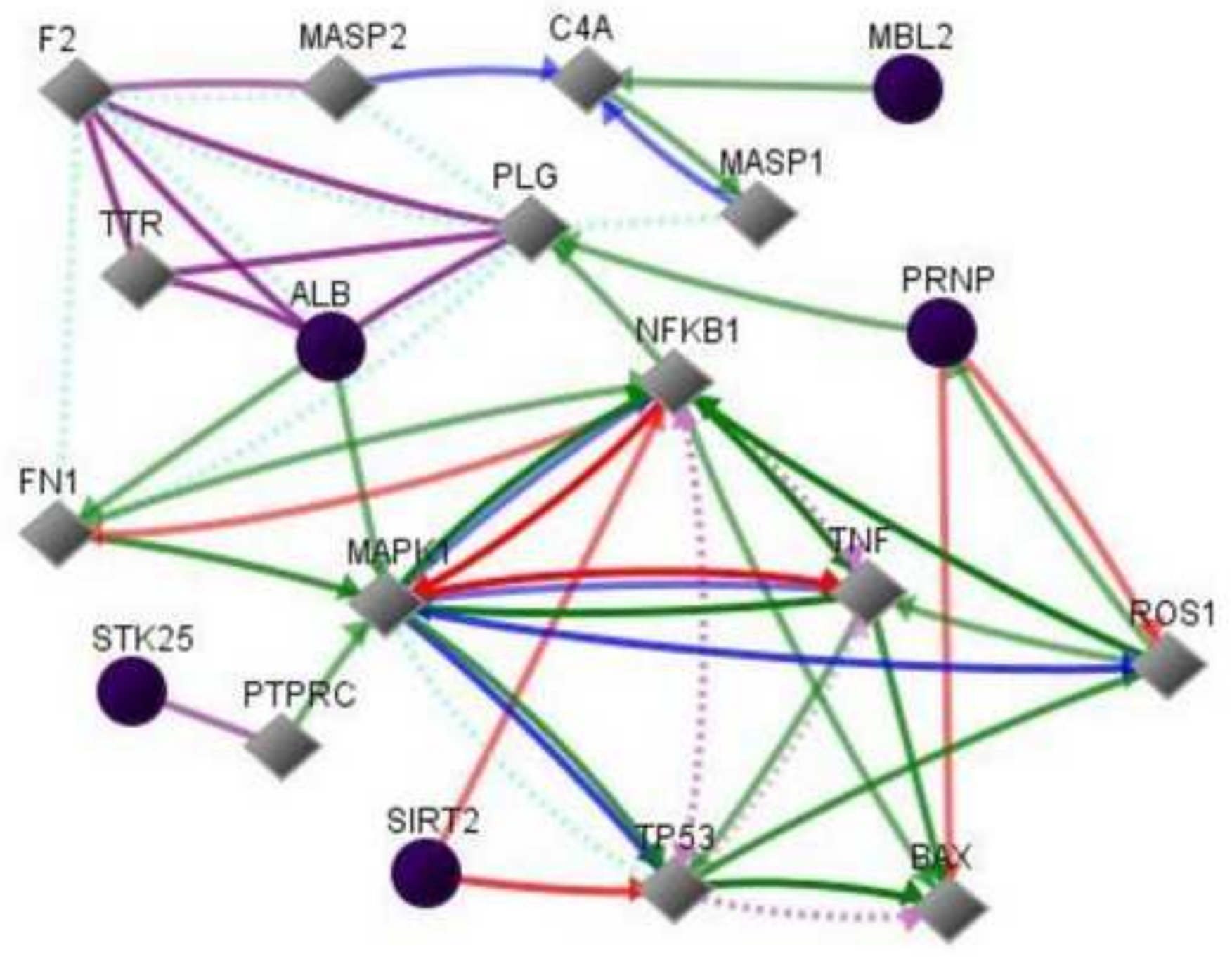

Known relationship between genes

- Down-regulation

- Up-regulation

- Coexpression

- Chemical modification

..... Predicted Protein Interaction

.... Predicted Transcription Factor regulation 


\section{Table 1Sb}

\begin{tabular}{|c|c|c|c|}
\hline Gene & RefSeqID & UnigenelD & Description \\
\hline$\overline{A L B}$ & NM_000477 & Hs.418167 & Albumin \\
\hline BAX & NM_004324 & Hs.624291 & BCL2-associated X protein \\
\hline C4A & NM_007293 & Hs.534847 & Complement component 4A (Rodgers blood group) \\
\hline $\mathrm{F} 2$ & NM_000506 & Hs.655207 & Coagulation factor II (thrombin) \\
\hline FN1 & NM_054034 & Hs.203717 & Fibronectin 1 \\
\hline MAPK1 & NM_002745 & Hs.431850 & Mitogen-activated protein kinase 1 \\
\hline MASP1 & NM_001879 & Hs.89983 & Mannan-binding lectin serine peptidase 1 (C4/C2 activating component of Ra-reactive factor) \\
\hline MASP2 & NM_006610 & Hs.655645 & Mannan-binding lectin serine peptidase 2 \\
\hline MBL2 & NM_000242 & Hs.499674 & Mannose-binding lectin (protein C) 2, soluble (opsonic defect) \\
\hline NFKB1 & NM_003998 & Hs.654408 & Nuclear factor of kappa light polypeptide gene enhancer in B-cells 1 \\
\hline PLG & NM_000301 & Hs.143436 & Plasminogen \\
\hline PRNP & NM_000311 & Hs.472010 & Prion protein \\
\hline PTPRC & NM_002838 & Hs.654514 & Protein tyrosine phosphatase, receptor type, C \\
\hline ROS1 & NM_002944 & Hs.1041 & C-ros oncogene 1 , receptor tyrosine kinase \\
\hline SIRT2 & NM_012237 & Hs.466693 & Sirtuin (silent mating type information regulation 2 homolog) 2 (S. cerevisiae) \\
\hline STK25 & NM_006374 & Hs.516807 & Serine/threonine kinase 25 (STE20 homolog, yeast) \\
\hline TNF & NM_000594 & Hs.241570 & Tumor necrosis factor (TNF superfamily, member 2) \\
\hline TP53 & NM_000546 & Hs.654481 & Tumor protein p53 \\
\hline TTR & NM_000371 & Hs.427202 & Transthyretin \\
\hline
\end{tabular}


Table 1S

Interactor 1

\section{ALB}

ALB

ALB

ALB

ALB

ALB

ALB

ALB

ALB

BAX

C4A

C4A

C4A

C4A

C4A

C4A

C4A

F2

F2

F2

F2

F2

F2

F2

F2

FN1

FN1

FN1

FN1

FN1

FN1

FN1

FN1

MAPK1

MAPK1

MAPK1

MAPK1

MAPK1

MAPK1

MAPK1

MAPK1

MAPK1

MAPK1

MAPK1

MAPK1

MAPK1

MAPK1

MAPK1

MAPK1

MAPK1

MAPK1

MAPK1

MASP2

MASP2

MASP2

MBL2

MBL2

MBL2

MBL2

MBL2

MBL2

MBL2
Interactor 2

F2

F2

FN1

MAPK1

PLG

PLG

TTR

TTR

TTR

ROS1

MASP1

MASP1

MASP1

MASP2

MASP2

MASP2

TNF

FN1

MAPK1

MASP2

MASP2

PLG

PLG

PLG

TTR

MAPK1

MAPK1

NFKB1

NFKB1

NFKB1

PLG

PLG

PLG

BAX

NFKB1

NFKB1

NFKB1

NFKB1

PTPRC

PTPRC

ROS1

ROS1

ROS1

TNF

TNF

TNF

TNF

TP53

TP53

TP53

TP53

TP53

MASP1

MASP1

PLG

C4A

F2

F2

MASP1

MASP1

MASP2

MASP2
Type

Predicted Protein Interaction

Pubmed

Up-Regulation

Up-Regulation

Predicted Protein Interaction

Coexpression

Coexpression

Physical Interaction

Other

Other

Up-Regulation

Chemical Modification

Other

Physical Interaction

Chemical Modification

Other

Other

Predicted Protein Interaction

Physical Interaction

Predicted Protein Interaction

Coexpression

Predicted Protein Interaction

Coexpression

Other

Coexpression

Up-Regulation

Other

Down-Regulation

Up-Regulation

Other

Predicted Protein Interaction

Physical Interaction

Other

Other

Down-Regulation

Up-Regulation

Chemical Modification

Other

Up-Regulation

Other

Regulation

Chemical Modification

Other

Down-Regulation

Up-Regulation

Chemical Modification

Other

Up-Regulation

Predicted Protein Interaction

Physical Interaction

Chemical Modification

Other

Physical Interaction

Other

Predicted Protein Interaction

Up-Regulation

Physical Interaction

Other

Physical Interaction

Other

Physical Interaction

Other

$\underline{12716133}$

$\underline{8240317}$

$\underline{9777418}$

17242371

$\underline{9777418}$

9777418
10200254,10573421

bioinformatics.ubc.ca/Gemma/mainMenu.html

16270194,12270980

15829704

10200254,10573421

bioinformatics.ubc.ca/Gemma/mainMenu.html

bioinformatics.ubc.ca/Gemma/mainMenu.html

12546731

18555006,14625274

pid.nci.nih.gov/InteractionPage?atomid=101689

17938215

pid.nci.nih.gov/InteractionPage?atomid=101689

17015733

12691705,15990085

$15128449,10200254,10573421$

pid.nci.nih.gov/InteractionPage?atomid $=103495$

10200254,10573421

bioinformatics.ubc.ca/Gemma/mainMenu.html

10200254,10573421

bioinformatics.ubc.ca/Gemma/mainMenu.html

11450845

bioinformatics.ubc.ca/Gemma/mainMenu.html

9148935,11278335,10860821,17933561

16960555

17065349

12138201,17929131

17273763,18064631

10200254,10573421

8360181,2531657

17656680

14522966

$11880271,15642734,18276112,17911635,10871852$

$16930953,14730209,17322278,16956941,14764702,18202112,10085062,120$ $91386,16581829,16966488,15670752$

15665723

$15073167,16966488,16912315,12068083$

12082107

$\underline{17651798,15829704,17050668,18270969,15778391}$

$\underline{17651798,18398338,18579320}$

17651798

$\underline{12878172,16081599,16431125,18314537,11994493,17172275}$

$12160518,15696199,18080320,16291755,11777983,16835229,9841871,1500$

$1576,16723255,15304089,9325311,12702497,17126905,9305639,15800027,1$ $\underline{0559258,17438131}$

18187448

14636891,17575006

$16282319,15592521,12091386,11409876$

10200254,10573421

11409876,10958792

11409876,10958792

18448277

10330290

10330290

$15128449,10200254,10573421$

$12601245,10330290,9777418,16112196,10946292,10925294,8921412,90874$

11,9719152

$11907111,12421953,10679061,12370377,10092804,12601245,10330290,977$

$\underline{7418,10946292,10925294,8921412,16102832,10878362,17442954,15728497}$, $16687626,12367778,18456010$

$10092804,10330290,9777418,16102832,17444953,10878362,18456010$

$11907111,12421953,16395704,10679061,12370377,10092804,18221301,151$

$17939,9777418,17971300,10946292,10925294,17096357,17565323,9087411$, $17045845,16102832,10878362,17442954,15728497,11426320,15746044,166$ $87626,12367778,18456010$

$10330290,16029433,10925294,17096357,17444953,15117939,18177377,108$

$\underline{78362,15746044,18456010}$ 


\begin{tabular}{|c|c|c|c|}
\hline NFKB1 & BAX & Up-Regulation & $\underline{14724581,18172861}$ \\
\hline NFKB1 & BAX & Other & 15613549 \\
\hline NFKB1 & PLG & Up-Regulation & 14704150,12690099 \\
\hline NFKB1 & PLG & Other & 14699120 \\
\hline PLG & MASP1 & Predicted Protein Interaction & $\overline{15128449,10200254,10573421}$ \\
\hline PLG & TTR & Coexpression & bioinformatics.ubc.ca/Gemma/mainMenu.html \\
\hline PRNP & BAX & Down-Regulation & 15846375,18006836 \\
\hline PRNP & PLG & Up-Regulation & 12719777,15140132 \\
\hline PRNP & PLG & Physical Interaction & $11100730,15140132,15609351$ \\
\hline PRNP & PLG & Other & 15140132 \\
\hline PRNP & ROS1 & Down-Regulation & $\underline{16582585}$ \\
\hline PRNP & ROS1 & Up-Regulation & 16120605,12957651 \\
\hline PTPRC & MBL2 & Physical Interaction & $\underline{11564800}$ \\
\hline PTPRC & MBL2 & Other & 11564800 \\
\hline PTPRC & STK25 & Coexpression & bioinformatics.ubc.ca/Gemma/mainMenu.html \\
\hline ROS1 & NFKB1 & Up-Regulation & $16619039,16286467,15254232,15944151,11997235$ \\
\hline ROS1 & NFKB1 & Other & $15727562,17729113,15581626$ \\
\hline SIRT2 & NFKB1 & Down-Regulation & 15632193 \\
\hline SIRT2 & TP53 & Down-Regulation & $\underline{15632193,18249187}$ \\
\hline SIRT2 & TP53 & Other & $\underline{12006491}$ \\
\hline TNF & BAX & Up-Regulation & $\overline{11571294,17724464}$ \\
\hline TNF & MBL2 & Physical Interaction & $\frac{17665457}{14530285} 125094691752173691101461724461312065326180672721770$ \\
\hline TNF & NFKB1 & Up-Regulation & $\begin{array}{l}\frac{1768,11374864,12712434,15273737,16798739,12486103,10725745,1034681}{8,18336259,15456791,8870842,16916598,9792645,15828019,15961886,1822} \\
2174,18089811,15687488,11594795,12783888,15941918,170882 \\
16581045,11734559,16527821,9560343,17766391,11821416,10580148,1239\end{array}$ \\
\hline TNF & NFKB1 & Other & $\begin{array}{l}\frac{1248,17303559,10485710,18202225,16040075,15140884,10744744,1248542}{4,15221897,15153500,14572449,17297444,11821383,16584809,16955245,12} \\
\frac{709429,11297557,14623898,15870274}{15025948,14685699,16607115,15390122,12168659,16116965,15052682,162}\end{array}$ \\
\hline TNF & NFKB1 & Predicted TFactor Regulation & $\begin{array}{l}\frac{05945,16640837,16125268,15731292,15019085,17084384,16702954,118844}{70,14963056,15128825,12657243,15800781,16540655,12929751,17005669,1} \\
5455409,16437600,12446019,15481297,16705808,16690985,128 \\
\end{array}$ \\
\hline TNF & ROS1 & Up-Regulation & $\overline{12384485,12417342}$ \\
\hline TNF & ROS1 & Other & $\underline{15944312} 15298965,15542843,11118038,18454316,12545155,14963330,16132718,175$ \\
\hline TP53 & BAX & Up-Regulation & $\frac{22316,11943780,12145207,15033690,15764647,7834749,18201273,1728984}{\frac{2,18084613,11956107,12811820,11388671,17189187,14726658,15024021,15}{851483,11960374,18172861,14625298,9194565,17245430,17016}}$ \\
\hline TP53 & BAX & Physical Interaction & 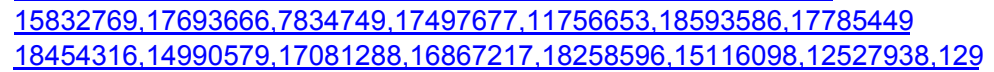 \\
\hline TP53 & BAX & Other & $\begin{array}{l}\frac{42774,18040854,11025664,9405685,11278647,16439685,15371445,1728050}{5,11175336} \\
\underline{17522316,17602169,11870542,15645135,15370668,11850816,17318220,121}\end{array}$ \\
\hline TP53 & BAX & Predicted TFactor Regulation & $\begin{array}{l}33040,15936790,12433990,15102481,14625298,15542843,16007146,161699 \\
39,17145718,16132718,16272691,12928149,12203124\end{array}$ \\
\hline TP53 & NFKB1 & Regulation & $\begin{array}{l}\underline{15378004,12808109,17363555,15073170,17499812,18172861,16684540,151} \\
\underline{02862,15719026,11809417,12091386}\end{array}$ \\
\hline TP53 & NFKB1 & Physical Interaction & 16887883,17908957 \\
\hline TP53 & NFKB1 & Other & $\underline{18172861,10760570,16007163}$ \\
\hline TP53 & NFKB1 & Predicted TFactor Regulation & $\underline{13679428,15955105,17308063,15372276,15081873}$ \\
\hline TP53 & ROS1 & Up-Regulation & $\underline{16652144,15705792,15765147,14612402}$ \\
\hline TP53 & ROS1 & Other & 14612402 \\
\hline TP53 & TNF & Up-Regulation & $\underline{12795334,8867673}$ \\
\hline TP53 & TNF & Other & $\underline{16684540,12165799}$ \\
\hline TP53 & TNF & Predicted TFactor Regulation & 12392301,16684540 \\
\hline
\end{tabular}


Table 2S

Control Population

Single-SNP analysis

\section{SNP: RS1467282}

Percentage of typed samples: $101 / 110(91.82 \%)$

\begin{tabular}{|l|l|l|l|l|l|l|}
\hline \multicolumn{7}{|c|}{ RS1467282 exact test for Hardy-Weinberg equilibrium (n=101) } \\
\hline & N11 & N12 & N22 & N1 & N2 & P-value \\
\hline $\begin{array}{l}\text { All } \\
\text { subjects }\end{array}$ & 73 & 26 & 2 & 172 & 30 & 1 \\
\hline TYPE=C & 73 & 26 & 2 & 172 & 30 & 1 \\
\hline
\end{tabular}

SNP: RS5952

Percentage of typed samples: 95/110 (86.36\%)

RS5952 exact test for Hardy-Weinberg equilibrium ( $n=95)$

\begin{tabular}{|c|c|c|c|c|c|c|}
\hline & N11 & N12 & N22 & N1 & N2 & P-value \\
\hline $\begin{array}{l}\text { All } \\
\text { subjects }\end{array}$ & 90 & 5 & 0 & 185 & 5 & 1 \\
\hline TYPE $=C$ & 90 & 5 & 0 & 185 & 5 & 1 \\
\hline
\end{tabular}

SNP: RS1568565

Percentage of typed samples: $97 / 110$ (88.18\%)

\begin{tabular}{|c|c|c|c|c|c|c|}
\hline \multicolumn{7}{|c|}{ RS1568565 exact test for Hardy-Weinberg equilibrium $(n=97)$} \\
\hline & N11 & N12 & N22 & N1 & N2 & P-value \\
\hline $\begin{array}{l}\text { All } \\
\text { subjects }\end{array}$ & 29 & 46 & 22 & 104 & 90 & 0.68 \\
\hline TYPE $=\mathrm{C}$ & 29 & 46 & 22 & 104 & 90 & 0.68 \\
\hline
\end{tabular}

CRC Population

\section{Single-SNP analysis}

\section{SNP: RS1467282}

Percentage of typed samples: 139/139 (100\%)

\begin{tabular}{|c|c|c|c|c|c|c|}
\hline \multicolumn{7}{|c|}{ RS1467282 exact test for Hardy-Weinberg equilibrium $(n=139)$} \\
\hline & N11 & N12 & N22 & N1 & $\mathbf{N 2}$ & P-value \\
\hline $\begin{array}{l}\text { All } \\
\text { subjects }\end{array}$ & 111 & 27 & 1 & 249 & 29 & 1 \\
\hline TYPE $=A$ & 111 & 27 & 1 & 249 & 29 & 1 \\
\hline
\end{tabular}

SNP: RS5952

Percentage of typed samples: $102 / 139$ (73.38\%)

\begin{tabular}{|c|c|c|c|c|c|c|}
\hline \multicolumn{7}{|c|}{ RS5952 exact test for Hardy-Weinberg equilibrium $(n=102)$} \\
\hline & \begin{tabular}{|l|l|l|l|l} 
N11 & \\
\end{tabular} & $\mathbf{N 1 2}$ & $\mathbf{N 2 2}$ & N1 & $\mathbf{N 2}$ & P-value \\
\hline $\begin{array}{l}\text { All } \\
\text { subjects }\end{array}$ & 101 & 1 & 0 & 203 & 1 & 1 \\
\hline TYPE $=\mathbf{A}$ & 101 & 1 & 0 & 203 & 1 & 1 \\
\hline
\end{tabular}

SNP: RS1568565

Percentage of typed samples: $102 / 139$ (73.38\%)

\begin{tabular}{|c|c|c|c|c|c|c|}
\hline \multicolumn{7}{|c|}{ RS1568565 exact test for Hardy-Weinberg equilibrium $(n=102)$} \\
\hline & N11 & N12 & N22 & N1 & $\mathbf{N 2}$ & P-value \\
\hline $\begin{array}{l}\text { All } \\
\text { subjects }\end{array}$ & 24 & 55 & 23 & 103 & 101 & 0.55 \\
\hline TYPE $=A$ & 24 & 55 & 23 & 103 & 101 & 0.55 \\
\hline
\end{tabular}


Table 3S

Control Population

Multiple-SNP analysis

\section{Haplotype}

analysis

\begin{tabular}{|r|c|r|r|r|r|r|}
\hline \multicolumn{7}{|c|}{ Haplotype frequencies estimation (n=102) } \\
\hline & $\mathbf{R S 1 4 6 7 2 8 2}$ & RS5952 & RS1568565 & Total & group Control & $\begin{array}{c}\text { Cumulative } \\
\text { frequency }\end{array}$ \\
\hline 1 & C & T & A & 0.4464 & 0.4464 & 0.4464 \\
\hline L & C & T & G & 0.3934 & 0.3934 & 0.8398 \\
\hline 3 & T & T & A & 0.0735 & 0.0735 & 0.9133 \\
\hline 4 & T & T & G & 0.0609 & 0.0609 & 0.9742 \\
\hline S & T & C & G & 0.014 & 0.014 & 0.9882 \\
\hline 6 & C & C & A & 0.0118 & 0.0118 & 1 \\
\hline T & T & C & A & & 0 & 1 \\
\hline
\end{tabular}

CRC Population

Multiple-SNP analysis

Haplotype

analysis

\begin{tabular}{|r|c|c|c|c|r|r|}
\hline \multicolumn{7}{|c|}{ Haplotype frequencies estimation (n=139) } \\
\hline & RS1467282 & RS5952 & RS1568565 & Total & group CRC & $\begin{array}{l}\text { Cumulative } \\
\text { frequency }\end{array}$ \\
\hline 1 & C & T & G & 0.4612 & 0.4612 & 0.4612 \\
\hline L & C & T & A & 0.4345 & 0.4345 & 0.8957 \\
\hline 3 & T & T & A & 0.0701 & 0.0701 & 0.9658 \\
\hline 4 & T & T & G & 0.0287 & 0.0287 & 0.9945 \\
\hline S & T & C & G & 0.0029 & 0.0027 & 0.9974 \\
\hline 6 & T & C & A & 0.0026 & 0.0028 & 1 \\
\hline 7 & C & C & A & 0 & 0 & 1 \\
\hline 8 & C & C & G & 0 & 0 & 1 \\
\hline
\end{tabular}

\begin{tabular}{|c|c|c|c|c|c|c|}
\hline \multirow{2}{*}{\multicolumn{7}{|c|}{$\begin{array}{c}\text { Control / CRC } \\
\text { Multiple-SNP analysis }\end{array}$}} \\
\hline & & sis & & & & \\
\hline \multicolumn{7}{|c|}{ Haplotype association with response ( $n=241$, crude analysis) } \\
\hline & RS1467282 & RS5952 & RS1568565 & Freq & OR (95\% CI) & P-value \\
\hline & $\mathrm{C}$ & $\mathrm{T}$ & $\mathrm{A}$ & 0.438 & 1 & \\
\hline & $\mathrm{C}$ & $\mathrm{T}$ & $\mathrm{G}$ & 0.4339 & $0.78(0.49-1.26)$ & 0.32 \\
\hline 3 & $\mathrm{~T}$ & $\mathrm{~T}$ & A & 0.073 & $0.92(0.38-2.27)$ & 0.86 \\
\hline 4 & $\mathrm{~T}$ & $\mathrm{~T}$ & G & 0.0412 & $2.41(0.65-8.98)$ & 0.19 \\
\hline rare & * & * & * & 0.0139 & $4.88(0.55-43.32)$ & 0.16 \\
\hline
\end{tabular}

Global haplotype association p-value: 0.17 
Dear Dr. Celis,

We are submitting our manuscript entitled "Expression and role of Apolipoprotein D on the deathsurvival balance of human colorectal cancer cells under oxidative stress conditions" by Raquel Bajo-Grañeras, Jesús Crespo Sanjuan, Rosa M. García Centeno, José Antonio Garrote-Adrados, Gabriel Gutierrez, Manuel García-Tejeiro, Beatriz Aguirre Gervás, María D. Calvo Nieves, Rosa Bustamante, Maria D. Ganfornina and Diego Sanchez, to be considered for publication in Molecular Oncology.

Our research program seeks to know the function of ApoD, a lipocalin that we have studied in the context of neuroprotection upon oxidative-stress (Current Biology, 2006; Aging Cell, 2008, PLoS Genetics, 2009; Glia, 2010; Glia, 2011).

Previous reports have uncovered a general downregulation of ApoD expression in many tumours. However, it is also well established that malignant tissues build up lipid peroxidation products, and our own work shows that ApoD is quickly and very effectively up-regulated by this oxidative stress situation.

Here we address this paradoxical behaviour of ApoD. We have confirmed in malignant tissue from colorectal cancer patients the overall down regulation of ApoD, at the mRNA and protein levels, as well as the increased lipid peroxidation status with tumour development. We then study the ApoD pattern of expression in tumour and normal mucosa by immunohistochemistry, and have uncovered a switch of ApoD expression from stromal cells to dysplastic epithelial cells in the cancer tissue. We also use colorectal cancer cell cultures to study the expression of ApoD under experimental oxidative stress conditions. Finally, we found no significant correlation between three reported SNPs for ApoD and the development of colorectal cancer.

Our results show that the expression of ApoD depends on the cancer cell requirements and that oxidative stress can still upregulate ApoD regardless of an overall methylated state of its promoter in cancer cells. Although cell growth arrest has been proposed as the underlying cause for ApoD downregulation, the addition of ApoD to cancer cells does not compromise the proliferation potential of these cells. In contrast, it promotes apoptosis upon paraquat-induced oxidative stress.

We believe these results advance our understanding of the anomalous physiological conditions in human colorectal cancer and about the mechanism by which ApoD is as a good prognostic marker for many cancer types. They indicate that a proper balance of ApoD concentration is needed by malignant cells to keep proliferating under the increasing amounts of lipid peroxidation generated by their own growth. When ApoD expression is up-regulated in this cell, however, it can switch the balance of death-survival towards apoptosis. This general conclusion opens an interesting potential use of controlled expression of ApoD for limiting cancer development.

Looking forward to hearing from you,

Sincerely yours,

Maria D. Ganfornina and Diego Sanchez

Lazarillo Lab

IBGM

University of Valladolid - CSIC

Spain 

5. Discusión general 



\section{Discusión general}

ApoD se ha vinculado con el envejecimiento, la degeneración y la lesión del sistema nervioso en multitud de estudios. Los trabajos relativamente recientes realizados en organismos modelo tan diferentes como plantas, moscas o ratones $^{1-5}$ han demostrado que ApoD contribuye de forma significativa a los mecanismos de supervivencia que se encuentran conservados en muchas especies en la lucha contra el estrés oxidativo en diversas situaciones. Nuestro grupo de investigación había encontrado una conexión entre la gestión de los lípidos peroxidados en el cerebro y la expresión de $A p o D^{2}$, sugiriendo que esta proteína realiza su función de protección mediante el control de los subproductos de las reacciones que se desencadenan con el estrés oxidativo. Sin embargo, no se había obtenido ninguna prueba directa que estableciera una relación causal entre ApoD y la vulnerabilidad de circuitos funcionales o la viabilidad celular ante el estrés oxidativo.

Los trabajos llevados a cabo durante esta tesis doctoral pretenden profundizar en esta función protectora que ApoD ejerce sobre células sometidas a estrés oxidativo tanto a nivel molecular, como celular, como tisular, así como el resultado final de su acción en la funcionalidad del sistema nervioso. Además nos hemos preguntado si las funciones que desempeña ApoD son generalizables a distintos tejidos y diferentes situaciones patológicas que prevalecen en el envejecimiento y en los cuales el estrés oxidativo es un factor fisiopatológico clave. Hemos seleccionado sistemas especialmente sensibles dentro del cerebro (el sistema dopaminérgico) así como una forma de cáncer muy prevalente en nuestra sociedad (el cáncer de colon).

El conjunto de resultados obtenidos descubren varios aspectos que iluminan de forma más fiable el mecanismo de acción de ApoD y sus repercusiones en diferentes situaciones normales o patológicas. 
Hemos observado que tanto la ausencia constitutiva de expresión de ApoD como la sobre-expresión de $A p o D$ en las neuronas de ratón desencadena cambios transcripcionales en el cerebelo del ratón adulto. La expresión de ApoD participa, en condiciones basales, en la regulación de genes implicados en la actividad eléctrica neuronal, en la función sináptica y en la homeostasis de la mielina. Este último conjunto de genes relacionados con la mielina del SNC y el hecho de que entre los genes dependientes de ApoD estén enriquecidos no sólo genes neuronales, sino oligodendrogliales, es de especial interés. Los oligodendrocitos son también células que expresan ApoD, mostrando un paralelismo con las células de Schwann en el SNP. En nervios periféricos ya se había observado ${ }^{6}$ que la falta de ApoD altera el grosor de la banda de mielina lo que provoca disminución en la velocidad de conducción nerviosa. Los datos ahora obtenidos en el SNC, traen a escena a los oligodendrocitos, abriendo así las puertas a nuevas preguntas sobre el papel de ApoD en la producción o el mantenimiento de la mielina, especialmente relevante para las situaciones patológicas desmielinizantes

Por otro lado hemos encontrado que la expresión de genes que controlan la respuesta celular a estímulos ambientales como Map3k7 y Ccl21 es también dependiente de la presencia de ApoD. Ante el estrés oxidativo el perfil de expresión en el cerebelo de genes dependientes de ApoD resalta, de forma esperada, genes implicados en la gestión del estrés oxidativo, pero también otros que están relacionados con el desarrollo del sistema nervioso, la diferenciación celular o el proceso de mielinización. Además también debemos destacar que la mayor parte de los genes que responden a este tipo de estrés son astrogliales y entre los dependientes de ApoD hay un enriquecimiento en genes oligodendrogliales. Ambos tipos celulares están muy relacionados con los dos procesos biológicos principales que aparecen como claramente dependientes de la función de ApoD en condiciones de estrés oxidativo: la gestión de la mielina y las respuestas gliales al estrés.

Debemos destacar que estos resultados ponen de manifiesto que ApoD es importante para configurar la respuesta transcripcional temprana del SNC ante el estrés oxidativo. Hasta el momento de su publicación este aspecto era 
desconocido ya que anteriormente no se habían empleado paradigmas experimentales a tiempos tan cortos.

Estos resultados revelan funciones biológicas generales de $A p o D$ dentro del sistema nervioso. El estudio dedicado al sistema dopaminérgico y a los astrocitos nos ha permitido afinar aún más su función.

La respuesta molecular en la sustancia negra ante el PQ nos volvió a destacar las diferencias existentes de manera constitutiva entre los animales ApoD-KO y los animales WT que apoyan la idea de que la falta de ApoD genera un estrés oxidativo basal. Pudimos comprobar la relación de ApoD con la respuesta glial en la sustancia negra: La falta de ApoD aumenta la expresión de GFAP, HO-1 y Sod2, genes que normalmente responden al estrés oxidativo.

Hemos demostrado que en los astrocitos la expresión de ApoD es regulada por la vía de señalización de JNK y hemos podido comprobar que su ausencia les hace mucho más vulnerables al estrés oxidativo. Esta vulnerabilidad se revierte con la adición de ApoD exógena, por lo que podemos concluir que ApoD ejerce un efecto beneficioso autocrino sobre las células gliales productoras. Podemos deducir que gracias a este efecto de mantenimiento sobre la glía, ApoD contribuye al mantenimiento de la homeostasis del sistema nervioso.

También hemos podido comprobar que ApoD no sólo ejerce una acción directa sobre la glía, si no también sobre las neuronas. ApoD mejora la viabilidad de neuronas sometidas a estrés oxidativo y también de neuronas que patológicamente generan altos niveles de ROS por tener disminuida la función del gen PINK1, una proteína asociada con la enfermedad de Parkinson que está implicada en el mantenimiento de la función mitocondrial. Este mecanismo neuroprotector está mediado por la activación de la vía de ERK. 
En resumen, las diferencias de expresión génica que hemos detectado en el entorno neuronal y en los astrocitos de los ratones ApoD-KO sugieren que en éstos existe un estrés oxidativo sostenido de manera basal, y una respuesta anómala de la red de genes que ha de organizarse para hacer frente al estrés oxidativo adicional inducido por PQ. Esto nos da idea de la función que desempeña $A p o D$ en el sistema nervioso y de un posible mecanismo de acción en ese tejido. La expresión de ApoD se induce en la glía en respuesta a un estrés y es entonces secretada. De forma temprana, ApoD es capaz de activar cascadas de señalización que promueven la supervivencia y genes de respuesta a estrés tanto en las neuronas como en la glía. En fases posteriores, ApoD se encontraría retirando lípidos peroxidados, esto evita la perpetuación y propagación del daño oxidativo, y permite poner fin a la respuesta de daño desencadenada. La célula puede volver a la normalidad.

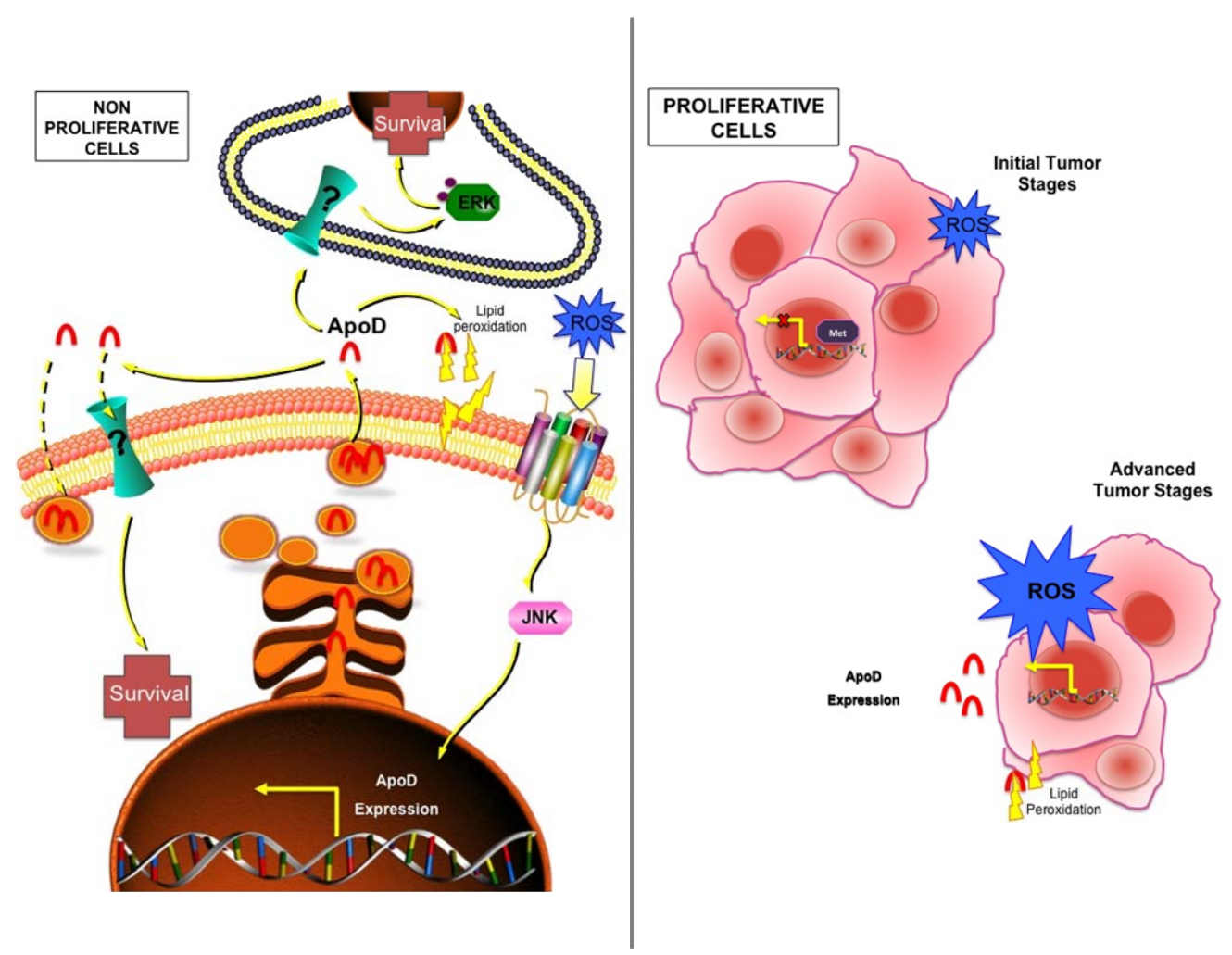

Nuestros resultados apoyan la idea de que la presencia de ApoD en el sistema nervioso es necesaria para una respuesta adecuada frente al estrés oxidativo que se produce de manera fisiológica o patológica. 
Nuestro análisis del perfil transcripcional en un cáncer, concretamente en el cáncer colorrectal, nos revela que el tejido sufre altos niveles de estrés oxidativo, pero también responde con altos niveles de antioxidantes. Hemos observado como en los estadios tumorales más avanzados la expresión de ApoD se reduce de manera global mientras aumentan los lípidos peroxidados. Sin embargo en esos estadios más avanzados aumenta el número de células del epitelio neoplásico que expresan la proteína tras la fuerte represión de los estadios iniciales del tumor. Este aumento viene acompañado de una disminución, casi desaparición de la expresión de ApoD en el estroma, lo que resulta en una bajada neta. En todo caso los crecientes niveles de ROS, originados por la gran tasa metabólica y la proliferación, parecen poder inducir la expresión de ApoD en estas células tumorales.

Hemos podido además comprobar en un sistema in vitro, que si las células tumorales están sometidas a estrés oxidativo y además son tratadas con $A p o D$, experimentan un aumento significativo de la muerte por apoptosis y una reducción de la proliferación. Este mecanismo puede explicar el hecho bien conocido de que la presencia de ApoD en un tumor puede interpretarse como un factor de buen pronóstico. Queda aún por conocer por qué unos tumores llegan a expresar niveles más altos de ApoD y otros no tanto. En todo caso, si ApoD consigue expresarse, puede realizar funciones proapoptóticas y frenar el crecimiento del tumor.

Podemos por lo tanto concluir que ApoD es una proteína protectora en diferentes sistemas, promoviendo supervivencia en células gliales y neuronales, pero promoviendo muerte celular en células neoplásicas sujetas a estrés oxidativo. Este es un curioso balance que necesita mucha y nueva investigación para terminar de comprenderlo. De alguna manera la evolución nos gana la carrera: la expresión de ApoD parece finamente regulada de forma que se expresa en el lugar, momento y cantidad adecuados para cada situación, desde el envejecimiento normal, hasta las patologías más diversas. 


\section{Bibliografía}

1. Charron JB, Ouellet F, Houde M, Sarhan F. The plant Apolipoprotein D ortholog protects Arabidopsis against oxidative stress. BMC Plant Biol. 2008;8:86.

2. Ganfornina MD, Do Carmo S, Lora JM, Torres-Schumann S, Vogel M, Allhorn M, González C, Bastiani MJ, Rassart E, Sanchez D. Apolipoprotein $D$ is involved in the mechanisms regulating protection from oxidative stress. Aging Cell. 2008;7(4):506-515.

3. Hull-Thompson J, Muffat J, Sanchez D, Walker DW, Benzer S, Ganfornina MD, Jasper $\mathrm{H}$. Control of metabolic homeostasis by stress signaling is mediated by the lipocalin NLaz. PLoS Genet. 2009;5(4):e1000460.

4. Ruiz M, Sanchez D, Canal I, Acebes A, Ganfornina MD. Sexdependent modulation of longevity by two Drosophila homologues of human Apolipoprotein D, GLaz and NLaz. Experimental Gerontology. 2011;doi: DOI: 10.1016/j.exger.2011.02.014.

5. Sanchez D, Lopez-Arias B, Torroja L, Canal I, Wang X, Bastiani MJ, Ganfornina MD. Loss of glial lazarillo, a homolog of apolipoprotein D, reduces lifespan and stress resistance in Drosophila. Curr Biol. 2006;16(7):680-686.

6. Ganfornina MD, Do Carmo S, Martínez E, Tolivia J, Navarro A, Rassart E, Sanchez D. ApoD, a glia-derived apolipoprotein, is required for peripheral nerve functional integrity and a timely response to injury. Glia. 2010;58(11):1320-1334. 
6. Conclusiones 



\section{A. Conclusions}

This work aims to grow deeper in the hypothesis that ApoD has a protective role and that it is one of the endogenous mechanisms of protection triggered both during normal aging and in pathological situations, especially in those associated with age.

This work demonstrates that:

1. The expression of $A p o D$ is part of the early response of the nervous system upon stimulation with pro-oxidant stimuli and, in turn, modulates neuronal and glial transcriptional activity, modifying genes that control neuronal excitability, synaptic function and myelin homeostasis.

2. ApoD contributes to the protection of the dopaminergic system through its expression in astrocytes induced by activation of the JNK pathway, by helping to restrain the extent of astrogliosis, and providing an autocrine protecting mechanism for these highly resistant glial cells. The autocrine protective mechanism is accompanied by the internalization of the protein from the extracellular environment into membranous compartments of astrocytes.

3. In addition to protecting sensitive dopaminergic neurons against oxidative stress through astrocytes, $A p o D$ has the ability to exert a direct neuroprotective effect on these neurons, even in the presence of mutations associated with the etiology of Parkinson's disease, thus contributing to the proper functioning of the dopaminergic system.

4. ApoD is part of a protection system against tumor cells that occurs when oxidative stress is high. In this case, ApoD does not promote survival or proliferation, but promotes the entry of cancer cells into the apoptotic program of cell death. 



\section{B. Conclusiones}

Este trabajo ha pretendido profundizar en la hipótesis de que ApoD desempeña un papel protector y que es uno de los mecanismos endógenos de protección que se pone en marcha tanto durante el envejecimiento normal como en situaciones patológicas, en especial, en las asociadas a la edad.

En este trabajo se demuestra que:

1. La expresión de $A p o D$ es parte de la respuesta temprana del sistema nervioso a estímulos pro-oxidantes y, a su vez, modula la actividad transcripcional neuronal y glial, modificando genes que controlan la excitabilidad neuronal, la función sináptica y la homeostasis de la mielina.

2. ApoD contribuye a la protección del sistema dopaminérgico mediante su expresión en astrocitos inducida por activación de la vía de JNK, contribuyendo a frenar la astrogliosis, y proporcionando protección autocrina para estas células gliales tan resistentes al estrés oxidativo. El mecanismo de protección autocrina viene acompañado de la internalización de la proteína desde el medio extracelular en compartimentos membranosos de los astrocitos.

3. Además de proteger a las sensibles neuronas dopaminérgicas frente al estrés oxidativo a través de los astrocitos, ApoD tiene la capacidad de ejercer un efecto neuroprotector directo sobre este tipo neuronal, incluso en presencia de mutaciones asociadas a la etiología de la enfermedad de Parkinson, contribuyendo así al correcto funcionamiento del sistema dopaminérgico.

4. ApoD forma parte de un sistema de protección contra las células tumorales que tiene lugar cuando el estrés oxidativo es elevado. En este caso, ApoD no promueve la supervivencia ni la proliferación, sino que promueve la entrada de las células cancerígenas en el programa apoptótico de muerte celular. 
